\author{
UNIVERSIDADE DE SÃO PAULO \\ FACULDADE DE FILOSOFIA, LETRAS E CIÊNCIAS HUMANAS \\ DEPARTAMENTO DE LETRAS MODERNAS \\ PROGRAMA DE PÓS-GRADUAÇÃO EM LÍNGUA, LITERATURA E \\ CULTURA ITALIANAS
}

ADROALDO JOSÉ FRANTZ

A compulsão à repetição do recalcado como base da elaboração temporal dos textos narrados por Zeno

Versão corrigida

São Paulo

2019 
UNIVERSIDADE DE SÃO PAULO

FACULDADE DE FILOSOFIA, LETRAS E CIÊNCIAS HUMANAS

DEPARTAMENTO DE LETRAS MODERNAS

PROGRAMA DE PÓS-GRADUAÇÃO EM LÍNGUA, LITERATURA E CULTURA ITALIANAS

\section{A compulsão à repetição do recalcado como base da elaboração temporal dos textos narrados por Zeno}

Versão corrigida

Adroaldo José Frantz

Tese apresentada ao Programa de PósGraduação em Língua, Literatura e Cultura Italianas do Departamento de Letras Modernas da Faculdade de Filosofia, Letras e Ciências Humanas da Universidade de São Paulo, para a obtenção do título de Doutor em Letras.

Orientadora: Profa. Dra. Adriana lozzi Klein

São Paulo

2019 
Autorizo a reprodução e divulgação total ou parcial deste trabalho, por qualquer meio convencional ou eletrônico, para fins de estudo e pesquisa, desde que citada a fonte.

Catalogação na Publicação

Serviço de Biblioteca e Documentação

Faculdade de Filosofia, Letras e Ciências Humanas da Universidade de São Paulo

F836C

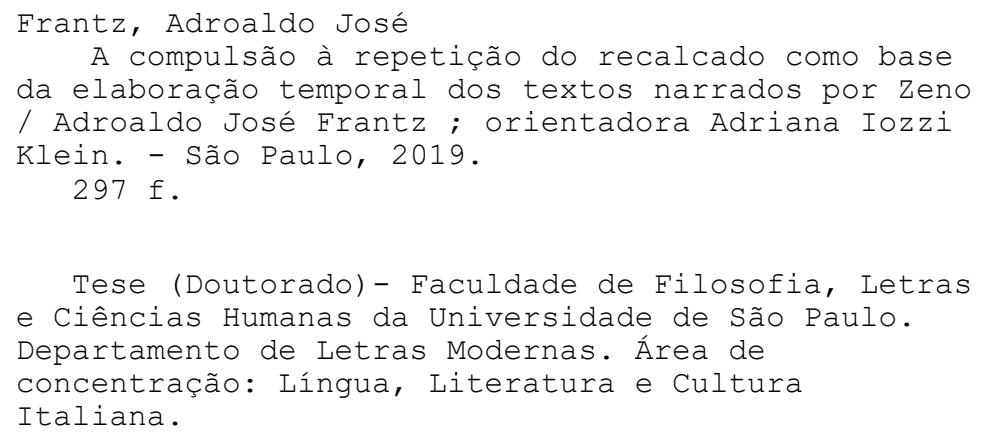




\section{ENTREGA DO EXEMPLAR CORRIGIDO DA DISSERTAÇ̃̃O/TESE}

Termo de Ciência e Concordância do (a) orientador (a)

Nome do (a) aluno (a): ADROALDO JOSE' FRANTZ Dome do Prof. (a) orientador (a): ADRIANA iOZZi KLE IN

Nos termos da legislação vigente, declaro ESTAR CIENTE do conteúdo deste EXEMPLAR CORRIGIDO elaborado em atenção às sugestões dos membros da comissão Julgadora na sessão de defesa do trabalho, manifestando-me plenamente favorável ao seu encaminhamento e publicação no Portal Digital de Teses da USP.

São Paulo, $10,10,20 / 9$

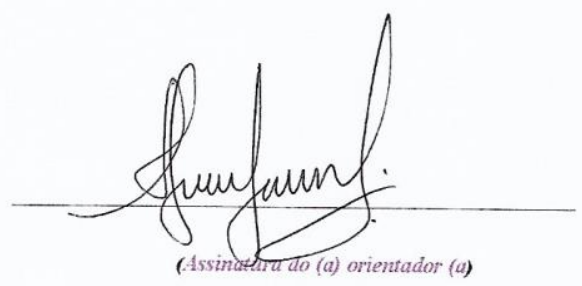




\section{FOLHA DE APROVAÇÃO}

Adroaldo José Frantz

A compulsão à repetição do recalcado como base da elaboração temporal dos textos narrados por Zeno

Tese apresentada à Faculdade de Filosofia, Letras e Ciências Humanas da Universidade de São Paulo para obtenção do título de Doutor. Área de Concentração: Literatura Italiana

Aprovado em:

Banca Examinadora

Prof. Dr.:

Instituição: Assinatura:

Prof. Dr.:

Instituição: Assinatura:

Prof. Dr.:

Instituição: Assinatura: 


\section{DEDICATÓRIA}

Ao meu grande amigo Carlos, pelo incentivo generoso e constante e pela valiosa ajuda. 


\section{AGRADECIMENTOS}

Aos meus pais Egomar (in memorian) e Ilse (in memorian), pelo amor e esforço com os quais proveram a educação dos filhos.

À minha esposa Adriana, que esteve ao meu lado durante todos os anos deste trabalho e se tornou companheira de sessões de escrita acadêmica nos últimos meses.

Aos meus filhos Artur e Pedro, pelo novo ânimo que continuamente me dão com a sua alegria e o constante desenvolvimento das suas capacidades.

À Profa. Dra. Adriana Iozzi Klein, pelo acolhimento que me deu desde o mestrado e por todo o apoio prestado durante a orientação. 


\section{RESUMO}

FRANTZ, A. F. A compulsão à repetição do recalcado como base da elaboração temporal dos textos narrados por Zeno. Tese de Doutorado (Área de Concentração: Literatura Italiana). Faculdade de Filosofia, Letras e Ciências Humanas, Universidade de São Paulo, São Paulo, 2019.

O nosso objetivo no presente trabalho é investigar em que medida uma estrutura bem específica de repetição, a noção psicanalítica de compulsão à repetição do recalcado, opera como a unidade temporal segundo a qual são construídos o protagonista e o narrador e são elaboradas as principais articulações temporais dos seguintes textos do escritor italiano Italo Svevo: o romance La coscienza di Zeno e as narrativas nas quais Zeno relata a própria história ulterior à do romance (Un contratto, Le confessioni del vegliardo, Umbertino, Il mio ozio e Prefazione), as quais ficaram inacabadas devido à morte de Svevo. No que se refere especificamente à compulsão repetitiva, exploramos como o protagonista e o narrador operam segundo séries de diversas recorrências que podem exercer influência umas sobre as outras e como as séries de ambos, apesar de temporalmente distintas, se encontram por meio da elaboração da narrativa; além disso, relacionamos a incapacidade para manter as principais séries compulsivas em operação com a condição tediosa que ocasionalmente assalta Zeno. Ampliando a nossa abordagem para um estudo abrangente da elaboração temporal nos textos do corpus da pesquisa, tanto investigamos como eles constroem diferentes articulações entre a silepse temática, a mudança incessante e casual, a temporalidade linear, considerada nos seus três principais componentes (a ordem cronológica, a causalidade e a elaboração bem articulada das expectativas), e a própria temporalidade recorrente que decorre do recalcamento quanto analisamos em que medida a repetição do recalcado e as suas mudanças determinam as seguintes transformações das referidas articulações: o predomínio da silepse temática no terceiro capítulo do romance, a subordinação da abordagem temática à cronológica no restante da autobiografia prescrita pelo psicanalista, o diário de escrita casual, a carta que encerra o diário com reflexões destinadas à edificação do doutor $\mathrm{S}$. e os textos ulteriores ao romance, os quais, em termos gerais, se destacam pela desvalorização da cronologia e pela reiterada afirmação do fim do ato de narrar pela justaposição de diversas partes narrativas fracamente 
articuladas entre si. Os principais autores que servem de base para as nossas investigações são, para as noções psicanalíticas, Freud e, para o tempo literário, Genette e Barthes. Também recorremos a vários críticos que se dedicaram à obra de Svevo, dentre os quais destacamos Barilli (2003), Lauretis (1976), Lavagetto (1975), Maxia (1977), Moloney (1998), Saccone (1970, 1973 e 1975), Savelli (1998) e Stasi (2009).

Palavras-chave: Italo Svevo, literatura italiana, tempo na literatura, compulsão à repetição do recalcado, psicanálise. 


\section{ABSTRACT}

FRANTZ, A. F. The repetition compulsion as the basis of the temporal elaboration of the texts narrated by Zeno. Doctorate's thesis (Italian Literature). Faculdade de Filosofia, Letras e Ciências Humanas, Universidade de São Paulo, São Paulo, 2019.

Our goal in the present paper is to investigate to what extent a very specific structure of repetition, the psychoanalytic notion of repetition compulsion, operates as the temporal unit according to which the protagonist and the narrator are constructed and the main temporal articulations of the following texts of the Italian writer Italo Svevo are elaborated: the novel La coscienza di Zeno and the narratives in which Zeno narrates his own later story to that of the novel (Un contratto, Le confessioni del vegliardo, Umbertino, Il mio ozio and Prefazione), which were unfinished due to the Svevo's death. Specifically with regard to the repetition compulsion, we explore how the protagonist and the narrator operate according to series of various recurrences that can influence each other and how the series of both, though temporally distinct, meet through the narrative elaboration; in addition, we relate the inability to keep the major compulsive series in operation with the tedious condition that occasionally assaults Zeno. Extending our approach to a comprehensive study of the temporal elaboration in the texts of the research corpus, first we investigate how they construct different articulations among the thematic syllepsis, the incessant and casual change, the linear temporality, considered in its three main components (the chronological order, the causality and the well-articulated elaboration of expectations), and the recurrent temporality itself that results from repression and then we analyze to what extent the repetition compulsion and its changes determine the following transformations of such articulations: the predominance of the thematic syllepsis in the third chapter of the novel, the subordination of the thematic approach to the chronological one in the rest of the autobiography prescribed by the psychoanalyst, the casual writing diary, the letter that encloses the diary with reflections for Dr. S.'s edification and the subsequent texts to the novel, which in general terms, stand out for the devaluation of the chronology and the repeated affirmation of the end of the narrative act by the juxtaposition of several weakly articulated narrative parts. The main authors who underlie our research are, for the psychoanalytic notions, Freud and, for the literary time, Genette and Barthes. We 
also draw on several critics who have devoted themselves to Svevo's work, among which we highlight Barilli (2003), Lauretis (1976), Lavagetto (1975), Maxia (1977), Moloney (1998), Saccone (1970, 1973 e 1975), Savelli (1998) e Stasi (2009).

Keywords: Italo Svevo, italian literature, time in literature, repetition compulsion, psychoanalysis. 


\section{RIASSUNTO}

FRANTZ, A. F. La coazione a ripetere come base dell'elaborazione temporale dei testi narrati da Zeno. Tesi di Dottorato (Area di Concentrazione: Letteratura Italiana). Faculdade de Filosofia, Letras e Ciências Humanas, Universidade de São Paulo, São Paulo, 2019.

Il nostro obiettivo in questo lavoro è investigare fino a che punto una struttura di ripetizione molto specifica, la nozione psicanalitica di coazione a ripetere, opera come unità temporale secondo la quale si costruiscono il protagonista e il narratore e si elaborano le principali articolazioni temporali dei seguenti testi dello scrittore italiano Italo Svevo: il romanzo La coscienza di Zeno e le narrazioni in cui Zeno racconta la propria storia dopo quella del romanzo (Un contratto, Le confessioni del vegliardo, Umbertino, Il mio ozio e Prefazione), che sono incompiute a causa della morte di Svevo. Per quanto riguarda la coazione a ripetere in particolare, esploriamo come il protagonista e il narratore operano secondo serie di ricorrenze diverse che possono influenzarsi a vicenda e come le serie di entrambi, sebbene temporalmente diverse, si incontrano attraverso l'elaborazione del racconto; inoltre, mettiamo in relazione l'incapacità di mantenere le principali serie compulsive in funzione con la condizione di noia che occasionalmente travolge Zeno. Cambiando il nostro approccio a uno studio ampio dell'elaborazione temporale nei testi del corpus della ricerca, oltre a investigare il modo in cui costruiscono articulazioni diverse tra sillessi tematica, cambiamento incessante e casuale, la temporalità lineare, considerata nei suoi tre componenti principali (l'ordine cronologico, la causalità e l'elaborazione ben articolata delle aspettative), e la temporalità ricorrente stessa derivante dalla repressione, analizziamo in che misura la coazione a ripetere e le loro modifiche determinano le seguenti transformazioni di tali articulazioni: il predominio della sillessi tematica nel terzo capitolo del romanzo, la subordinazione dell' approccio tematico al cronologico nel resto dell'autobiografia prescritta dallo psicanalista, il diario di scrittura casuale, la lettera che chiude il diario con riflessioni volte a educare il dottore S. e i testi dopo il romanzo, che, in termini generali, si distinguono per la svalutazione della cronologia e per la ripetuta affermazione della fine dell'atto narrativo dalla giustapposizione di diverse parti narrative debolmente articolate. I principali autori su cui si basano le nostre indagini 
sono, per le nozioni psicanalitiche, Freud e, per il tempo letterario, Genette e Barthes. Ci siamo rivolti anche a diversi critici che si sono dedicati al lavoro di Svevo, tra i quali Barilli (2003), Lauretis (1976), Lavagetto (1975), Maxia (1977), Moloney (1998), Saccone (1970, 1973 e 1975), Savelli (1998) e Stasi (2009).

Parole chiavi: Italo Svevo, letteratura italiana, tempo in letteratura, coazione a ripetere, psicanalisi. 


\section{SUMÁRIO}

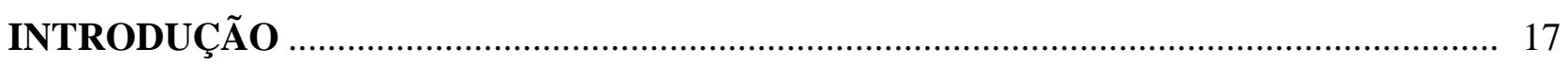

\section{A REPETIÇÃO DO RECALCADO COMO COMPONENTE DA DIEGESE DOS} TEXTOS NARRADOS POR ZENO

2.1 As séries básicas de repetição: o desejo pela mãe 47

2.2 As séries básicas de repetição: a rivalidade contra o pai 54

2.3 Os conflitos transitórios entre as repetições e o estabelecimento da sucessão diegética a despeito da recorrência 70

2.4 A instauração de ciclos no conflito: a repetição oscilatória ........................................... 80

2.5 A interrupção da repetição e a tendência a evitá-la ....................................................... 89

\section{A REPETIÇÃO DO RECALCADO E A ELABORAÇÃO DAS ARTICULAÇÕES}

TEMPORAIS NO ROMANCE LA COSCIENZA DI ZENO - OS DOIS CAPÍTULOS INICIAIS E A AUTOBIOGRAFIA

3.1 Uma primeira abordagem do rompimento com a temporalidade linear. 96

3.2 As relações temporais no âmbito da temporalidade manifestada por Zeno: o embate entre as temporalidades linear e de onda

3.3 A superação do âmbito da temporalidade manifestada por Zeno: uma introdução.

3.4 A configuração temporal da autobiografia de Zeno como superação do âmbito da sua experiência manifesta: a compulsão à repetição do recalcado fora da diegese. 
3.5 A configuração temporal da autobiografia de Zeno como superação do âmbito da sua experiência manifesta: as articulações da compulsão à repetição do recalcado com as temporalidades linear e de onda

\section{A REPETIÇÃO DO RECALCADO E A ELABORAÇÃO DAS ARTICULAÇÕES \\ TEMPORAIS NO ÚlTIMO CAPÍTULO E NO ÂMBITO GLOBAL DO}

ROMANCE LA COSCIENZA DI ZENO

4.1 A articulação da repetição do recalcado com o contexto clínico: a primeira seção do diário e o propósito subjacente à escrita das seções iniciais

4.2 A segunda seção e a adoção da forma temporal do diário de escrita casual: as mudanças na repetição do recalcado com a primeira cura parcial de Zeno

4.3 A seção final do último capítulo como carta hostil para o rival: a segunda cura parcial de Zeno e as mudanças ambientais e na repetição do recalcado

4.4 As transformações da repetição do recalcado e das articulações temporais no âmbito global do romance: da autobiografia às previsões evolutivas sobre o destino da humanidade

\section{A REPETIÇÃO DO RECALCADO E A ELABORAÇÃO DAS ARTICULAÇÕES TEMPORAIS NAS "CONTINUAÇÕES"}

5.1 A organização temporal específica da diegese do texto Un contratto: a gradual recaída na repetição da rivalidade edipiana e na temporalidade da nota única

5.2 A diegese e a narrativa em cada uma das "continuações": a diegese entre a segunda cura parcial e a recaída de Zeno e a articulação temporal entre a história e a narrativa 220

5.3 A constituição de Zeno como escritor das "continuações"

5.4 As consequências da constituição de Zeno como escritor: a construção da narrativa nas "continuações" com base na retomada das repetições do recalcado

5.5 As consequências da constituição de Zeno como escritor: o limite da retomada das repetições do recalcado e as suas consequências para as articulações temporais das "continuações". 
CONCLUSÃO

REFERÊNCIAS BIBLIOGRÁFICAS 


\section{INTRODUÇÃO}

O nosso objetivo no presente trabalho é investigar em que medida uma estrutura bem específica de repetição, a compulsão à repetição do recalcado, opera como a unidade temporal segundo a qual são construídos o protagonista e o narrador e são elaboradas as principais articulações temporais dos textos que compõem o nosso corpus, todos devidos ao escritor italiano Italo Svevo: o romance La coscienza di Zeno e as narrativas nas quais Zeno volta a contar a própria história para tratar do período ulterior ao do romance, as quais chamaremos simplesmente de "continuações" no restante deste trabalho.

Investigando o tema apresentado, não pretendemos revelar a única interpretação válida para o nosso corpus ou adotar a única perspectiva capaz de oferecer tais interpretações, ainda mais considerando que se trata de narrativas notáveis pela ambiguidade. O que nos importa é estabelecermos a validade da nossa proposta de análise, que consideramos ser particularmente fecunda em elaborar relações entre os mais diversos elementos literários dos textos e que esperamos que possa ser articulada com outras propostas convergentes a fim de aprimorar os estudos svevianos. Uma vez que fizemos tais considerações, esclareçamos que nos dedicaremos no presente trabalho a elaborar uma ampla argumentação em favor da nossa proposta, justamente para que estabeleçamos a sua validade em meio aos variados resultados disponíveis na fortuna crítica sobre Svevo.

A nossa escolha do referido tema tem origem no nosso mestrado, no qual dedicamos um capítulo ao estudo da temporalidade no romance La coscienza di Zeno, mas fomos incapazes de desenvolver plenamente tal estudo, pois extrapolaria o escopo da nossa dissertação. De qualquer modo, essa experiência nos deixou a sugestão de que a importância do tratamento do tempo no romance La coscienza di Zeno seria de tal ordem que esse texto mereceria ser examinado a partir da perspectiva do tempo (em oposição a meramente ser mais um dos aspectos secundários da análise), podendo contribuir com resultados que também influenciariam investigações segundo outros aspectos igualmente importantes. Assim, o presente trabalho se apoia em diversos resultados inicialmente obtidos no nosso mestrado, mas aprofunda a investigação, 
principalmente no que se refere às repetições do narrador e às suas consequências, e amplia o campo de análise pelo acréscimo das "continuações" ao nosso corpus.

Decidimos desenvolver a proposta sugerida pela realização do mestrado com base tanto na importância que a crítica costuma conceder ao aspecto temporal no caso do romance moderno, no qual se insere Svevo a partir do romance protagonizado por Zeno, quanto em o próprio escritor se dedicar de modo especial à questão do tempo ao longo de praticamente toda a sua produção.

Consideremos sucintamente alguns indícios da referida dedicação ao tempo ao longo dos escritos de Svevo. O tempo recebe uma atenção particular desde os primeiros textos de Svevo, como mostram tanto o aspecto temporal da divergência dos protagonistas ineptos dos seus dois primeiros romances em relação aos burgueses com os quais convivem, conforme comenta, por exemplo, o crítico Renato Barilli (2003, p. 57) a respeito do protagonista do romance Una Vita, quanto a noção de organismos que estão disponíveis para o futuro, que ele propõe a partir da teoria evolutiva de Darwin, como já foi analisado pelo crítico Sandro Maxia (1990, p. 23-24). Inclusive, ambos os aspectos estão presentes - a defasagem temporal entre as pessoas é até mesmo elaborada em termos biológicos - no conto Lo specifico del dottor Menghi.

O tempo é crucial para o romance La coscienza di Zeno, como já assinalava um dos seus primeiros admiradores, o grande escritor James Joyce, numa carta de 30 de janeiro de 1924: "Per ora due cose mi interessano. Il tema: non avrei mai pensato che il fumare potesse dominare una persona in quel modo. Secondo: il trattamento del tempo nel romanzo" (SVEVO, 1965, p. 29).

Após o terceiro romance, o escritor tematiza frequentemente questões sobre o tempo e a recordação, tal como o que chama de tempo misto (BARILLI, 2003, p. 124), o qual é oposto aos tempos puros da gramática para basicamente insistir numa composição temporal pela qual cada instante também deve ser considerado com o passado e o futuro que continuam a ser capazes de influenciar a ação do sujeito. Destaquemos também que muitas vezes Svevo aborda a escrita do presente e do passado. Neste trabalho, exploraremos o quanto essas questões aparecem nas "continuações", mas por ora citemos outros escritos de Svevo, tais como o conto Una burla riuscita, no qual encontramos a correção do acontecimento por meio do seu relato, e anotações dispersas nas quais se afirma a diferença entre a vida e a recordação que temos dela (1968, p. 839) pela comparação com a diferença entre a comida e o 
resultado da sua digestão ou pela correção do acontecimento por meio da sua recordação.

Também amparamos a nossa opção por investigar o tratamento do tempo nos textos narrados por Zeno na consideração da fortuna crítica de Svevo. Situaremos a nossa proposta dentro dessa fortuna crítica no próximo capítulo, mas adiantemos os resultados relevantes para a presente exposição. É comum que os críticos dediquem uma parte do seu estudo sobre Svevo à questão do tempo, mas ela geralmente fica restrita ao necessário para a investigação do assunto efetivamente abordado. Além disso, a maioria das análises trata basicamente de um conjunto recorrente de questões, de modo que há poucas abordagens alternativas. Dentre essas, há a consideração de repetições que o protagonista-narrador Zeno praticaria sem um controle voluntário, que só encontramos em alguns estudos svevianos fora do Brasil e, mesmo assim, de modo bastante restrito, pois concebem tal repetição operante apenas no protagonista do romance e basicamente limitada aos casos reconhecidos como uma recorrência pelo próprio Zeno e, num desses estudos, aos sintomas representados no protagonista.

Logo, a nossa pesquisa se propõe a introduzir a repetição involuntária de Zeno nos estudos svevianos no Brasil e, no caso da crítica estrangeira de Svevo, contribuir para superar as restrições sob as quais é considerada tanto pelo aumento decisivo da sua importância ao identificar uma grande variedade de manifestações repetitivas que não são reconhecidas por Zeno e os efeitos produzidos pelas relações que as recorrências estabelecem entre si e pela reação à potencial interrupção das mesmas quanto pela ampliação do alcance dessa repetição explorando como ela é igualmente relevante no caso do narrador e para a análise das "continuações".

Para encerrarmos as nossas considerações sobre a escolha do tema da nossa pesquisa, apresentemos sucintamente o envolvimento de Svevo com teorias da sua época, inclusive a psicanálise, a fim de esclarecer que não há nenhuma incompatibilidade no recurso que fazemos a uma noção psicanalítica, a compulsão à repetição do recalcado, como principal componente para o estudo do nosso corpus, dado que o próprio escritor defendia a apropriação literária do pensamento teórico.

No que tange à relação com a teoria em geral, Barilli comenta que Svevo meditou intensamente sobre o direito de o escritor recorrer ao pensamento de filósofos e cientistas justamente porque ele mesmo teve Arthur Schopenhauer e Charles Darwin como principais referências em vez de poetas ou romancistas (2003, p. 34-35). Ainda mais contundente é a seguinte avaliação de Maxia, da qual o presente trabalho serve de 
exemplo no que se refere à relação entre a psicanálise com os textos narrados por Zeno:

Su questo punto le idee di Svevo sono chiare: se c'è una costante nella sua poetica dagli anni del noviziato letterario a quelli della maturità, questa può essere individuata nella convinzione che quando si afferma in campo scientifico e culturale una nuova "teoria", l'arte "prima o poi ci si avvicinerà in colori e fantasie", ossia la farà propria nei modi specifici del suo operare formale. $(1977$, p. 8$)$

De fato, Svevo já abordava a referida questão num artigo de 18 de setembro de 1884, pelo qual respondia a uma acusação de que o escritor francês Zola haveria pretendido provar uma nova teoria científica por meio dos seus romances:

Egli non si prefisse di provare le teorie di Darwin che ammise a priori per provate, e l'idea della tesi, o almeno di questa tesi, non appare dai suoi romanzi. Più logico, più completo il suo sistema non potrebbe essere, e precisamente, prescindendo dal valore artistico intrinseco dell'opera letteraria, l'idea scientifica dell'eredità è entrata al luogo che occupava il destino nella tragedia greca e con il medesimo diritto. Non scienziato ma artista, Zola descrive la vita servendosi di una teoria scientifica che gliela spiega. Se questa teoria venisse scartata da altra, i nostri posteri vedrebberro, nell'opera di Zola, una rappresentazione della vita quale la sentono i più colti dei nostri contemporanei. (1968, p. 590)

Portanto, é válido que a obra literária se fundamente nas novas teorias que surgem, e ela continua a ter valor mesmo se a teoria na qual se baseia for descartada. Apesar da importância concedida à apropriação artística das teorias, Svevo reconhecia que há problemas inerentes a esse processo. Ele sintetizou esse duplo aspecto de tal apropriação ao declarar que a relação entre o teórico e o artista "somiglia al matrimonio legale perché non s'intendono fra di loro proprio come il marito e la moglie e tuttavia come il marito e la moglie producono dei bellissimi figliuoli” (1968, p. 687).

Quanto às vantagens da relação entre o teórico e o artista, Svevo assinalou a ampliação do público alcançado pelo primeiro e a renovação, em maior ou menor grau, proporcionada ao segundo (1968, p. 687-688). No tocante ao desentendimento entre os dois, ele parece surgir devido ao artista não se propor a ser um mero divulgador que estivesse dedicado a esclarecer as ideias de uma teoria, pois, como Svevo comenta, as falsifica para humanizá-las (1968, p. 686). Um dos riscos para o artista seria falhar em tal humanização, e Svevo, numa carta de 1928 para Valerio Jahier, um jovem italiano residente em Paris, confessou haver incorrido nesse risco no seu primeiro romance: "Io ne so qualche cosa per quello che m'avvenne con Una vita fatto tutto nella luce della teoria di Schopenhauer. E talvolta mi pare di sentire che la chiusa di quel romanzo non abbia maggior calore della conclusione di un sillogismo" (1965, p. 249). 
Por sua vez, o próprio criador da teoria pode falhar em reconhecê-la após ela ser humanizada pelo artista, conforme o relato de Svevo (1968, p. 687) a respeito da relação entre Schopenhauer e o compositor Richard Wagner, o qual enviou a sua música para o filósofo, a quem considerava como mestre, mas recebeu como resposta que Schopenhauer queria que apenas a música de Rossini estivesse associada ao seu nome. Ao terminar o relato, Svevo observa que, no seu tempo, os próprios discípulos do filósofo são de outra opinião.

Svevo até mesmo criou um exemplo bastante instrutivo da sua concepção da apropriação artística das teorias (1968, p. 687), no qual um artista conta a Albert Einstein que imaginou um modo de apresentar a sua teoria da relatividade aos que não conhecem a matemática necessária para entendê-la: admitindo que existisse um homem cujo coração batesse muito mais lentamente do que o normal, ele veria o sol cruzar o céu com grande rapidez. Por fim, Einstein responde ao artista que tal ideia não tem nada a ver com a relatividade que teorizou. De fato, tanto concordamos com a suposta rejeição da ideia pelo físico, na medida em que este não teria nenhuma razão para usar a sua teoria da relatividade do movimento a fim de explicar o fenômeno imaginado, quanto reconhecemos que o artista cria uma situação na qual um observador percebe a duração de um movimento corriqueiro de modo diferente de uma pessoa comum, reproduzindo, de um modo acessível ao público leigo em matemática, a variação de uma grandeza física das mais básicas - o tempo - conforme o observador, de modo equivalente ao preconizado por Einstein para observadores com velocidades diferentes.

Uma vez que tratamos da relação de Svevo com a teoria em geral, nos concentremos especificamente na sua ligação com a psicanálise. Ora, para um escritor que tinha uma relação tão fecunda e consciente com o pensamento científico e filosófico, o contato com a psicanálise só poderia se tornar um acontecimento de grande importância. Assim, não deve nos espantar que Svevo faça um resumo desse contato no texto Profilo autobiografico:

Il secondo avvenimento letterario e che allo Svevo parve allora scientifico fu l'incontro con le opere del Freud. Dapprima le affrontò solo per giudicare delle possibilità di una cura che veniva offerta ad un suo congiunto. Per vario tempo lo Svevo lesse libri di psicanalisi. [...] Durante la guerra, nel 1918, per compiacere un suo nipote medico che, ammalato, abitava da lui, si mise in sua compagnia a tradurre l'opera del Freud sul sogno. [...] Fu allora che lo Svevo talora si dedicò (solitario, ciò ch'è in perfetta contraddizione alla teoria e alla pratica del Freud) a qualche prova di psicanalisi su se stesso. (1968, p. 807) 
O parente mencionado na citação é o cunhado "Bruno Veneziani, fratello minore di Livia [esposa de Svevo], amico e compagno di studi di Edoardo Weiss [primeiro psicanalista da cidade, Trieste]" (LAVAGETTO, 1975, p. 39), o qual foi tratado pelo próprio Freud. Logo, Svevo teve um paciente do criador da psicanálise no seu círculo familiar, mas o longo tratamento fracassou (SVEVO, 1968, p. 688).

Outra fonte de proximidade com Freud, a qual ele não incluiu no resumo citado, é apresentada numa carta a Jahier, de 10 de dezembro de 1927: "E conobbi alcuni medici che lo [Freud] circondano" (1965, p. 239). Um desses médicos foi o próprio Weiss, o qual, ainda estudante de medicina, conheceu Freud pessoalmente e aprendeu a técnica psicanalítica em Viena (GHIDETTI, 2006, p. 240-241). Em 1911, também conheceu um dos fundadores da primeira sociedade psicanalítica, Wilhelm Stekel, do qual talvez haja se tornado correspondente (GHIDETTI, 2006, p. 237).

Retomando o resumo citado, Svevo também nos informa que leu livros de psicanálise. Até mesmo se empenhou em traduzir um deles, mais precisamente, iniciou uma tradução do livro Über der Traum, de 1901 (GHIDETTI, 2006, p. 237). Além desse livro, Svevo mencionou (1968, p. 688) as célebres conferências de Freud, que podem ser tanto a primeira série das Conferências introdutórias sobre psicanálise, realizadas em 1916 e 1917, quanto as Cinco lições de psicanálise, proferidas em 1909 (LAVAGETTO, 1975, p. 41-42). Quanto aos demais livros de Freud que o escritor haveria lido antes de escrever o terceiro romance, podemos apenas fazer conjecturas; por exemplo, numa delas (PETRONIO, 1988, p. 62) é afirmado que Svevo provavalemente leu os livros A interpretação dos sonhos, de 1900, Sobre a psicopatologia da vida cotidiana, de 1901, Os chistes e sua relação com o inconsciente, de 1905, e talvez Três ensaios sobre a sexualidade, de 1905. O que nos importa é que a suposta quantidade de leituras, considerando apenas obras escritas por Freud, já indica um grande interesse pela psicanálise.

No resumo citado, o escritor também nos informa que se dedicou a uma autoanálise. Além do interesse que essa iniciativa demonstra, o próprio Svevo considera que ela ainda seria responsável, no mínimo, pelo surgimento do seu terceiro romance (1965, p. 239). Ele demonstra estar ciente das limitações da autoanálise ao mencionar, ainda no mesmo resumo, a contradição com o que Freud defendia e praticava, mas o valor da psicanálise para o autor é enfatizado, pois essas limitações o motivam a dizer, em cartas para Jahier, que haveria sido melhor para o livro se ele houvesse sido 
realmente psicanalisado, pois haveria sido mais honesto (1965, p. 248) e o romance haveria ficado mais inteiro (1965, p. 243).

Por fim, dispomos de afirmações bastante claras do próprio Svevo sobre a importância que concede à psicanálise, inclusive para a literatura, que contrabalançam quaisquer ressalvas que lhe possa ter, com exceção das suas pretensões terapêuticas: "Ma c'è la scienza per aiutare a studiare sé stesso. Precisiamo anche subito: La psicanalisi” (1968, p. 685); "Ma quale scrittore potrebbe rinunziare di pensar almeno la psicanalisi? [...] Ma la psicanalisi non m'abbandonò più" (1968, p. 688); "Grande uomo quel nostro Freud ma più per i romanzieri che per gli ammalati” (1965, p. 239); "Letterariamente Freud è certo più interessante [do que terapeuticamente]" (1965, p. 243); e "E se credo che Freud sia un grande maestro è perché credo conferisca la debita importanza alle nostre esperienze" (1965, p. 248).

Apesar do amplo e profundo interesse de Svevo pela psicanálise que resulta das referências que acumulamos nos parágrafos anteriores, o escritor não se limitou a pura e simplesmente adotá-la, aplicando as suas concepções do modo mais direto possível. Em conformidade com a sua concepção sobre a apropriação artística das teorias, Svevo não opta por ser um mero divulgador, o que pode frustrar expectativas e provocar malentendidos sobre a maneira pela qual a psicanálise é tratada no romance. É o próprio escritor quem nos relata um desses mal-entendidos numa carta a Jahier:

\footnotetext{
Quando publicai il Zeno con mio grande dolore ebbi da un dottore psicanalista la dichiarazione che dal mio romanzo traspariva la mia assoluta ignoranza di psicanalisi. Non solo dall'ultimo capitulo ma ancora più che degli altri dall'ultimo perché qui pare che l'atteggiamento dell'ammalato non sia quello che gli ammalati hanno in quei frangenti né quello del medico quello che il medico deve avere secondo i dettami di quella pratica. (1965, p. 248)
}

O psicanalista mencionado na citação é Weiss, identificado em outro texto no qual Svevo conta o mesmo episódio (1968, p. 686). Quanto ao que Weiss explicitamente critica, as atitudes do médico e do paciente, ele parece estar certo. Em nenhum dos encontros relatados com o doutor S., Zeno demonstra a preocupação de alguém que tem a sua vida e a dos seus próximos prejudicadas por um sofrimento psíquico, como esperamos de uma pessoa que resolva despender tempo e dinheiro com sessões de psicanálise. No tocante às atitudes do médico, o crítico Mario Lavagetto conclui, após listar dez normas de conduta do psicanalista que ele encontra nos textos de Freud e dos seus seguidores, que Weiss tem razão (1975, p. 57). 
Por conseguinte, admitimos que haveria fundamentação para considerarmos que a afirmação de Weiss está certa na medida em que a relação clínica entre o psicanalista e o paciente não está de acordo com uma caracterização realista nem com os ditames da psicanálise, mas reconhecer isso nos parece servir justamente como indício de que devemos afastar expectativas de que o romance seja uma mera representação fiel da realidade ou uma simples obra de divulgação da criação freudiana. Por fim, consideramos significativo que Svevo, ao não se defender das críticas explicitadas, não proponha na carta que o seu romance não fosse baseado na psicanálise ou que fosse crítico a ela.

Em suma, como podemos constatar por meio das informações biográficas que apresentamos, o encontro com as obras de Freud foi tão relevante para Svevo que deve ser considerado, como ele mesmo diz, um acontecimento literário. Amparados nesse resultado obtido da biografia do escritor, avaliamos que seja muito temerário delimitar previamente o uso que Svevo fez da psicanálise nos textos narrados por Zeno na medida em que hipóteses a esse respeito sempre deveriam ter esses textos como uma das bases para serem examinadas, aprovadas ou contestadas. No que tange ao romance, podemos mesmo remeter ao seguinte parecer favorável de Lavagetto sobre o recurso à psicanálise: "I confini della critica letteraria (meno netti probabilmente di quanto si possa credere o sperare) non subiscono in questo caso nessun attacco: perché la psicoanalisi è nel romanzo e cercarvela non costituisce una importazione di contrabbando" (1975, p. 58).

Encerremos as nossas considerações sobre o recurso que fazemos a uma noção psicanalítica como principal componente para o presente trabalho com um esclarecimento final: assim como Svevo defendia que a falsidade de uma teoria não invalidaria as apropriações que os artistas fizeram dela na medida em que elas continuariam a propiciar uma representação da vida tal como foi concebida pelas pessoas mais cultas de uma sociedade, a nossa proposta de investigação tampouco exige que a psicanálise seja uma teoria verdadeira, pois o que nos importa é que as noções psicanalíticas nos permitam uma fecunda exploração da complexidade das relações entre os mais diversos elementos que constituem as narrativas do nosso corpus, principalmente no que se refere às relações temporais.

Uma vez que justificamos o tema que escolhemos para o presente trabalho, apresentemos as questões que nos orientarão na nossa pesquisa. Em primeiro lugar, pretendemos determinar em que medida, nos textos do nosso corpus, o protagonista e o 
narrador são construídos segundo a compulsão à repetição do recalcado; em outras palavras, especificar em que grau as ações de ambos e a escrita da narrativa são compulsivamente permeadas por recorrências sem que o protagonista-narrador Zeno saiba precisamente o que está repetindo. Em segundo lugar, objetivamos determinar em que medida as principais articulações temporais dos textos do nosso corpus são elaboradas segundo essa compulsão. Em terceiro e último lugar, pretendemos expor quais são as mudanças relevantes na repetição do recalcado, nas articulações temporais dos textos e nas relações entre elas, principalmente à medida que mudam as condições clínicas de Zeno tanto como protagonista quanto como narrador e o tipo de escrita que adota, inclusive no que se refere às diferenças entre o terceiro romance de Svevo e as "continuações". Esclareçamos também que, ao nos dedicarmos à pesquisa dessas questões, a nossa proposta não é comprovar que os textos de Svevo sejam exemplares das inovações temporais que caracterizam o romance moderno; o que nos interessa é abordar justamente o que pode haver de específico nas contribuições do escritor triestino para a elaboração da temporalidade no romance.

Não apresentaremos os capítulos que planejamos para o presente trabalho nesta introdução porque decidimos apresentá-los no primeiro capítulo, dedicado a situar a nossa abordagem dentro da fortuna crítica de Svevo e expor o embasamento teórico da nossa investigação, pois entendemos que a apresentação dos capítulos ganhará em clareza ao ser feita quando já houvermos introduzido as perspectivas que adotamos em relação à crítica sveviana e às teorias literárias sobre o tempo.

Encerremos esta introdução com três esclarecimentos. O primeiro deles é que a palavra "repressão" e outras da mesma família que aparecem em algumas citações que fazemos de Freud designam a mesma noção psicanalítica para a qual usamos a palavra "recalque", a qual é a tradução atualmente usada para essa noção.

O segundo esclarecimento é que, a fim de que o nosso trabalho possa ser útil a um público mais amplo, optamos por fornecer a tradução dos textos citados em outras línguas na nota de rodapé sempre que tivemos acesso a uma edição em português do texto original. Só indicamos algum problema nessas traduções em caso de erro gramatical ou se for relevante para a nossa análise.

Por fim, o terceiro esclarecimento é dedicado à identificação precisa das "continuações", às condições sob as quais Svevo as criou e ao modo pelo qual as abordaremos, no que se refere a essas condições. Os textos que compõem as “continuações” são: Un contratto, Le confessioni del vegliardo, Umbertino, Il mio ozio 
e Prefazione. Dado que eles não foram publicados por Svevo, explicitemos que usamos a edição crítica dos estudiosos Nunzia Palmieri e Fabio Vittorini (SVEVO, 2004, p. 1087-1234).

A edição que utilizamos também traz os fragmentos que estão ou podem ser reunidos a cada um desses textos (SVEVO, 2004, p. 1651-1664). São trechos que se destacam graficamente do texto principal e geralmente estão escritos em outros papéis (SVEVO, 2004, p. 1630-1636). O texto Il mio ozio possui cinco fragmentos; os demais, apenas um. Além disso, é o único a ter fragmentos de mais de uma página: dois deles ocupam duas páginas.

O contexto da produção das "continuações" é o projeto de Svevo de escrever um novo romance, como está registrado em cartas trocadas nos seus últimos meses de vida (SVEVO, 2004, p. 1637). Citemos trechos da primeira e da última dessas cartas que foram escritas por Svevo. A primeira delas é de 16 de maio de 1928, enviada a Benjamin Crémieux: "Del resto dopo alcune settimane meno buone sto tanto bene che, con improvvisa decisione, mi sono messo a fare un altro romanzo, Il Vecchione, una continuazione di Zeno. Ne scrissi una ventina di pagine e mi diverto un mondo" (1965, p. 97-98). A última carta na qual Svevo se referiu ao novo romance é de 19 de agosto do mesmo ano, enviada a Marie Anne Comnène: "Vorrei fare un altro romanzo: Il Vegliardo, una continuazione di Zeno. Ne ho steso varii capitoli che però tutti devono essere rifatti. C'è un certo suono falso che vi si insinua. Che sia l'incapacità del vecchio?" (1965, p. 138-139). Svevo viajou no dia 25 do mesmo mês e morreu no dia 13 do mês seguinte devido a um acidente na viagem de retorno (SVEVO, 2004, p. 1638). Logo, houve pouco tempo para que o escritor refizesse os capítulos conforme pretendia.

Em suma, os cinco textos das "continuações" ainda não haviam sido finalizados e foram escritos por Svevo com o objetivo de serem reunidos num novo romance que estava em pleno processo de escrita. Além disso, o escritor não deixou indicações sobre a ordem na qual deveriam ser apresentados. Sem informações sobre as mudanças que Svevo pretendia fazer nesses textos nem sobre o que desejava para o novo romance como um todo, precisamos adotar critérios segundos os quais abordaremos as "continuações", e eles devem ser bastante simples, dada a escassez de informações. O primeiro deles trata de como abordaremos cada texto: trataremos cada um como um capítulo do romance e analisaremos cada um da maneira como Svevo os deixou, ou seja, sem tentarmos imaginar as modificações que o escritor ainda faria. $\mathrm{O}$ 
segundo e último critério trata de como abordaremos as relações entre os capítulos: limitar-nos-emos a um tratamento comparativo ao considerar essas relações, pois não sabemos sequer a ordem entre os capítulos ou se outros ainda seriam escritos, e desconsideraremos o que provavelmente seria revisado ao reuni-los, tais como momentos da história que são relatados mais de uma vez, repetições de reflexões do narrador e pequenos materiais narrativos que são diversamente aproveitados.

Para encerrar a nossa introdução, exponhamos como trataremos os fragmentos. No que se refere a eles, também adotaremos um critério bastante simples: desprezaremos todos justamente porque foram classificados como fragmentos, ou seja, não puderam ser diretamente integrados ao texto das "continuações" ao qual estão associados. 


\section{Capítulo 1 \\ CONTEXTUALIZAÇÃO CRÍTICA E EMBASAMENTO TEÓRICO}

Neste capítulo situamos a perspectiva que adotamos para o presente trabalho dentro da fortuna crítica de Svevo e apresentamos tanto o arcabouço teórico sobre o tempo que embasa a nossa investigação quanto os capítulos nos quais estudamos os textos que compõem o corpus do nosso trabalho.

Comecemos abordando os estudos sobre Svevo no Brasil. Vários deles abarcam apenas a obra máxima do escritor, La coscienza di Zeno: os de Ramos (2001) e de Sanches (2003) a comparam a um romance brasileiro, Memórias póstumas de Brás Cubas; o de Patrícia de Cia (2008) a situa em relação à sua época e à tradição do romance europeu; o de Castelan (2008) investiga a constituição identitária de Zeno; e o de Souza (2015) trata da ironia como princípio formal do texto. Os demais estudos fazem recortes diversos da produção literária de Svevo: o de Vicentini (1984) examina os romances do ponto de vista da dissolução das formas tradicionais do gênero e da subjetivação da narrativa; o de Santos (2001) é uma tradução comentada de textos inacabados com a narração de Zeno; os de Miorin (2006 e 2013) abarcam diversas narrativas de Svevo e analisam, respectivamente, o aparato crítico como elemento constitutivo dos textos e a composição delas segundo a noção de narcisismo literário; o de Castelan (2014) aborda o ciúme nos romances; e o de Sanches (2016) trata do processo de construção de personagens anti-heróis, também nos romances. Por fim, a investigação de Roque (2010) aborda o livro La coscienza di Zeno apenas de modo secundário, pois trata primariamente do sujeito por meio da relação entre literatura e psicanálise e usa trechos desse livro e de um de Luigi Pirandello como exemplos da sua análise.

Com base no levantamento apresentado, constatamos que não há nenhum estudo brasileiro dedicado exclusivamente aos aspectos temporais da produção literária de Svevo. Apesar disso, a maioria tem algumas páginas que tratam do tempo em um ou mais textos do escritor, ainda que a análise fique restrita ao necessário para a investigação do assunto efetivamente abordado. Só encontramos uma abordagem de maior fôlego no livro de Roque (2010), no qual há um capítulo, intitulado Narratividade e temporalidade, que é integralmente voltado às questões sobre o tempo. De modo geral, as considerações que os estudos brasileiros fazem sobre o tratamento temporal 
nos textos de Svevo se concentram em dois aspectos. O primeiro deles é o estabelecimento de um tempo subjetivo na narrativa, cujas características mais destacadas são o rompimento com a cronologia e a multiplicidade de contextos temporais pelos quais o relato passa mesmo numa frase ou na passagem de uma frase para outra. O segundo aspecto é a recriação do passado conforme as mudanças pelas quais Zeno passa; nesse sentido, a tese de Miorin (2013) até mesmo adota a leitura de que o narrador das "continuações" efetivamente criaria o "passado", de modo que, mais do que contar uma história, o que importaria seria a criação de um discurso.

A base da nossa investigação - a repetição involuntária e, em geral, desconhecida do próprio protagonista-narrador Zeno mesmo na sua mera natureza repetitiva - está ausente dos aspectos temporais nos quais se concentram os estudos brasileiros. Inclusive, como examinaremos no presente trabalho, ela propicia o entendimento de que a recriação do passado é causada menos pelas mudanças ocorridas ao longo do tempo do que pela permanência de um mesmo padrão repetitivo. O livro de Roque (2010) menciona tal repetição, mas a sua abordagem fica restrita ao contexto clínico da transferência psicanalítica, não sendo explorada no âmbito da análise literária.

Ampliando as nossas considerações para contemplar também a fortuna crítica de fora do Brasil, comecemos por tratar das obras que, tal como o presente trabalho, recorrem a categorias psicanalíticas. Notemos que, apesar da relevância da psicanálise para Svevo, só poucos livros dos melhores críticos svevianos se dedicam efetivamente à relação entre o escritor e a psicanálise. Os demais a abordam brevemente no contexto de outra questão ou, no máximo, dedicam-lhe uma seção da obra, o que dificulta que seja dado um tratamento aprofundado a essa relação. De fato, ela tanto demora a ser estudada em detalhe - os primeiros textos dedicados especificamente a ela são artigos da década de 50 - quanto se torna um aspecto central somente de modo muito esporádico nos livros publicados após a década de 70. Contemplando desde a década de sessenta até 1994 e, portanto, incluindo o auge da produção em análise, o crítico Massimiliano Tortora enumera como autores de interpretações ligadas a categorias psicanalíticas: "Lavagetto, Saccone, Gioanola, Fusco, De Lauretis, Petroni” (2004, p. 170).

Dentre os críticos citados, são relevantes para o presente trabalho Mario Lavagetto (1975), Eduardo Saccone (1973 e 1995) e Teresa de Lauretis (1976). Ainda não trataremos dos dois últimos, pois consideramos mais apropriado abordá-los com outros críticos que destacam a importância da repetição na elaboração de Zeno como 
personagem. Não é o caso de Lavagetto, como pode ser observado no capítulo que intitula Sucessione (1975, p. 74-87) e que dedica à análise do tempo no principal romance de Zeno recorrendo explicitamente às relações temporais entre a história e a narrativa que são estudadas pelo teórico Gérard Genette, as quais comentaremos ainda neste capítulo. De fato, ele trata das relações de ordem (1975, p. 76-81) e de velocidade (1975, p. 83-84), contudo nem mesmo menciona a relação de frequência, pela qual Genette considera a repetição. Apesar disso, recorremos a resultados das análises de Lavagetto para nos apoiar em determinados aspectos relevantes para a nossa investigação e assinalaremos tais apropiações nos momentos adequados.

Uma vez que abordamos a fortuna crítica que recorre a categorias psicanalíticas, consideremos os demais críticos estrangeiros. Em termos gerais, os aspectos que eles privilegiam na análise da temporalidade nos textos do nosso corpus são os mesmos que assinalamos no caso dos estudos brasileiros. Façamos três ressalvas a essa avaliação geral. A primeira delas resulta da quantidade bem maior de autores que abordam as "continuações", tais como Barilli (2003), Biasin (1984), Ghidetti (2006) e Tedesco (1999): há um relevante reforço na importância dada à multiplicidade dos contextos temporais e à recriação do passado, já que tais aspectos são tematizados em diversas reflexões do narrador desses textos.

A segunda das ressalvas em análise é que alguns autores propõem que o acaso seja um dos elementos cruciais da temporalidade do romance La coscienza di Zeno, seja por meio da contingência resultante da disposição indiferente de Zeno no caso de Barilli (2003), seja por meio da ausência de sentido nos casos de Guglielmi (1986) e de Savelli (1998). A última das ressalvas em análise é que alguns críticos que não adotam propriamente uma perspectiva psicanalítica também destacam a importância da repetição, mesmo que ela não seja reconhecida por Zeno. É o caso de Biasin (BUCCHERI; COSTA, 1995, p. 129-138) e de Mussara-Schroder (1994).

Uma vez que esboçamos as tendências mais disseminadas da fortuna crítica sobre a temporalidade nos textos do nosso corpus, consideremos em que medida os críticos que destacam a repetição involuntária de Zeno, que está na base do presente trabalho, efetivamente se aproximam da nossa proposta. Saccone, Lauretis, MussaraSchroder e Biasin assinalam a relevância da repetição para o principal romance de Svevo, ainda que considerem-na operante apenas no protagonista e basicamente restrita aos casos reconhecidos como uma recorrência pelo próprio Zeno e, no caso específico de Lauretis, aos sintomas representados no protagonista. Conforme trataremos com mais 
detalhe ainda neste capítulo, propomos que a recorrência é igualmente relevante para a análise das "continuações"; aumentamos decisivamente a sua importância ao identificar uma grande variedade de manifestações repetitivas que não são reconhecidas por Zeno; detectamos a relação de conflito que frequentemente é criada entre as múltiplas repetições, dando especial atenção àquela que resulta numa articulação em ciclos ou oscilatória de duas ou mais recorrências; e estabelecemos como ela também opera no caso do narrador.

Após situarmos a nossa proposta para o presente trabalho frente à fortuna crítica de Svevo, apresentemos, em termos gerais, o seu embasamento teórico, cuja filiação é dupla: psicanálise e teoria literária. Durante essa apresentação, também indicaremos como usamos esse embasamento para estruturar os capítulos desta tese. Comecemos por delimitar com clareza que a base da nossa investigação não é uma repetição qualquer, mas uma bem específica; mais precisamente, ela é um componente de um fenômeno patológico estudado pela psicanálise, a compulsão à repetição do recalcado. Eis uma citação na qual Freud é especialmente contundente sobre essa compulsão: "o paciente não recorda coisa alguma do que esqueceu e reprimiu, mas expressa-o pela atuação ou atua-o. Ele o reproduz não como lembrança, mas como ação; repete-o, sem, naturalmente, saber o que está repetindo" (1969, p. 196). Por um lado, o paciente está desvinculado de uma parte do seu passado, que não recorda nem reconhece nas ações pelas quais a reproduz. Por outro lado, as repetições nas ações passadas ou presentes do paciente são um vínculo com essa parte do passado; se elas puderem ser identificadas, poderiam servir como material para a investigação do que foi esquecido. Freud até mesmo constatou que a recuperação dos momentos recalcados na clínica psicanalítica é feita segundo uma ordem bastante específica das recordações:

[...] nem sempre era um único acontecimento que deixava atrás de si os
sintomas; para produzir tal efeito uniam-se na maioria dos casos numerosos
traumas, às vezes análogos e repetidos. Toda essa cadeia de recordaçôes
patogênicas tinha então de ser reproduzida em ordem cronológica e
precisamente inversa - as últimas em primeiro lugar e as primeiras por último
- sendo completamente impossível chegar ao primeiro trauma, muitas vezes
o mais ativo, saltando-os sobre os que ocorreram posteriormente. (2006, p.
31)

A hipótese de que Zeno - como personagem e narrador, já que ele narra a própria história - seja construído pelo texto segundo a compulsão à repetição do recalcado exige que fiquemos especialmente atentos às relações dos acontecimentos da história com o que se passa quando ela é contada. Assim, a ação do protagonista é 
permeada por repetições que ele não reconhece como tais e o narrador as relata na mesma ignorância, além de poder submetê-las a repetições que operem no momento do relato, as quais igualmente não serão reconhecidas como recorrências.

Interrompamos brevemente a nossa exposição para retomar as considerações gerais que fizemos na introdução ao presente trabalho sobre o recurso à psicanálise para investigar os textos narrados por Zeno. Faremos isso a fim de explicitar como o próprio romance do nosso corpus introduz um contexto psicanalítico que o engloba totalmente, como podemos constatar remetendo sucintamente às próprias situações narrativas que o compõem: o prefácio fictício do psicanalista de Zeno, que seria o responsável pela publicação do livro; os capítulos autobiográficos que o paciente escreve como preparação para a terapia; e o diário que o paciente escreve após abandonar o tratamento, no qual ele começa relatando o período da terapia, prossegue fazendo menções a ela e termina respondendo a uma carta do psicanalista e finalmente se declarando curado. Logo, se recorreremos à condição patológica de Zeno e a noções psicanalíticas para entender a ação do protagonista e o relato do narrador é porque se trata de meios de investigação que o próprio romance coloca à nossa disposição e, portanto, eles só podem ser confirmados ou refutados com base nele. O presente trabalho é justamente uma tentativa de confirmá-los.

Retomando a nossa hipótese de Zeno ser elaborado conforme a compulsão repetitiva do recalcado, podemos nos questionar se o protagonista e o narrador conseguiriam superar o desconhecimento das repetições de modo a estabelecer uma ação e um relato coerentes. Não, se continuarmos a nos ater ao que Freud pensou sobre a relação do paciente com o próprio passado, como explicita sobre uma das principais modalidades de psicopatologia que ele estudou: "Nas muitas formas diferentes da neurose obsessiva, em particular, o esquecer restringe-se principalmente à dissolução das vinculações de pensamento, ao deixar de tirar as conclusões corretas e isolar lembranças" (1976a, p. 195). Logo, também deveríamos ficar atentos às manipulações temporais do texto que resultam em omissões e incongruências narrativas, mesmo que inicialmente estas pareçam irrelevantes. Para reforçarmos a importância de semelhantes manipulações do ponto de vista psicanalítico, apresentemos uma citação de Freud na qual ele destaca especificamente uma delas como uma técnica fundamental da distorção onírica:

[...] a inversão cronológica não deve ser negligenciada. Uma técnica bastante comum da distorção do sonho consiste em representar o resultado de um acontecimento ou a conclusão de uma cadeia de ideias no início de um sonho, 
e em colocar em seu final as premissas em que se basearam a conclusão ou as causas que levaram ao acontecimento. Quem quer que deixe de ter em mente esse método técnico adotado pela distorção onírica ficará inteiramente perdido quando se deparar com a tarefa de interpretar um sonho. (1987a, p. 313)

Com base em tais considerações, concluímos que precisamos nos amparar em estudos de teoria literária que privilegiem as relações temporais entre os próprios elementos textuais. É o que nos fornece o teórico Gérard Genette na sua obra Discurso da narrativa, na qual, já no início, distingue claramente não só dois mas três aspectos da realidade narrativa:

Proponho [...] denominar-se história o significado ou conteúdo narrativo (ainda que esse conteúdo se revele, na ocorrência, de fraca intensidade dramática ou teor factual), narrativa propriamente dita o significante, enunciado, discurso ou texto narrativo em si, e narração o acto narrativo produtor e, por extensão, o conjunto da situação real ou fictícia na qual toma lugar. (1987, p. 25)

Cada um dos três aspectos narrativos possui o seu próprio tempo (Genette também emprega o termo "diegese" para se referir à história). A distinção entre os tempos da história e da narrativa é bastante difundida, mas o da narração é explorado com bem menos frequência. Talvez isso se deva a este ser de pouca importância para muitos textos, mas é crucial quando há um narrador cuja repetição patológica pode exercer múltiplas influências sobre aqueles dois tempos.

Antes de continuarmos a exposição do nosso embasamento teórico, apresentemos o segundo capítulo do presente trabalho, o qual concebemos como uma preparação para abarcar a complexidade da nossa tarefa, com a qual lidaremos, por sua vez, com base na divisão do tempo segundo os aspectos da realidade narrativa. A nossa tarefa é complexa devido à própria compulsão à repetição do recalcado, a começar pela falta de reconhecimento por quem está submetido à compulsão, a qual exige que descubramos cada uma das recorrências do recalcado encontrando algumas das suas ocorrências e relacionando-as entre si numa série repetitiva. Além disso, as repetições não ocorrem isoladamente, mas podem conflitar entre si, o que dificulta ainda mais a tarefa de descobri-las na medida em que o conflito causa a inibição temporária de uma ou mais recorrências.

Mais uma camada de complexidade é acrescentada porque o próprio Zeno é o narrador. O texto se desenvolve com Zeno em duas instâncias temporais diferentes, a da história e da narração, e , portanto, as repetições nos dois casos podem divergir, dado que as condições nas quais cada uma opera são diferentes. Assim, surge a possibilidade 
de erros de análise causados pela confusão entre repetições divergentes do protagonista e do narrador. Ainda mais grave nesse cenário de divergência, as repetições do narrador podem operar implicitamente dentro dos tempos da narrativa e da história, o que pode ser bastante complexo de identificar.

Em suma, a situação geral propicia uma grande complexidade: há o desenvolvimento simultâneo de duas séries, a do protagonista e do narrador, de múltiplas repetições que se caracterizam pela falta de reconhecimento e são potencialmente conflitantes entre si, e ambas são potencialmente divergentes a cada momento do relato, de modo que as repetições do narrador podem distorcer implicitamente o que é relatado.

Diante de tal complexidade, em vez de tentarmos analisar simultaneamente as repetições do protagonista e do narrador, concebemos o próximo capítulo como uma etapa preparatória da nossa investigação, na qual focaremos no tempo da história dos textos do nosso corpus, de modo que nos restringiremos a trabalhar com aquelas ocorrências de repetições do protagonista que conseguimos identificar nos trechos voltados ao desenvolvimento diegético e para os quais não encontramos indícios da intervenção do narrador. Desse modo, inicialmente devemos lidar apenas com a complexidade da série de repetições do protagonista. Como restrição adicional ao escopo desse capítulo, evitaremos o tempo da história do diário que encerra o romance devido ao contexto clínico que lhe é próprio e do qual trataremos no quarto capítulo deste trabalho.

Uma vantagem adicional de um capítulo preparatório que foca no tempo da história é responder a outra complexidade, a da multiplicidade de interpretações vigentes sobre os acontecimentos narrados na volumosa fortuna crítica sobre Zeno. Assim, esclarecemos o nosso entendimento básico sobre diversas etapas da diegese antes de recorrer à argumentação mais intrincada de que necessitaremos para tratar dos trechos mais complexos nos demais capítulos.

Aproveitemos para adiantar que, apesar de ser preparatório, o segundo capítulo é razoavelmente extenso. Ora, dada a importância que atribuímos à repetição do recalcado para os textos narrados por Zeno, uma das tarefas que devemos cumprir na defesa da nossa proposta é justamente explicitar a abrangente disseminação das ocorrências dessa repetição na própria materialidade dos textos. Como nem Zeno nem grande parte da fortuna crítica as reconhecem - e mesmo os poucos críticos que o fazem se limitam a uma gama bastante restrita de casos, conforme já assinalamos -, a referida 
abrangência da disseminação da repetição do recalcado é um elemento dos textos narrados por Zeno que ainda precisa ser devidamente estabelecido dentro dos estudos svevianos, o que fundamenta a abundante exemplificação com a qual elaboramos o segundo capítulo.

Adotaremos o critério de exemplificação que aplicamos no parágrafo anterior para o presente trabalho como um todo: usaremos poucos exemplos quando se tratar de assunto já bem estabelecido dentro da fortuna crítica de Svevo e embasaremos os assuntos que ainda foram pouco explorados com uma quantidade maior de exemplos. Aproveitemos também para esclarecer que daremos preferência para a citação direta de trechos das "continuações", por ainda serem pouco estudadas no Brasil, ou para os quais dermos interpretações menos literais e convencionais.

Para encerrarmos a apresentação do próximo capítulo, exponhamos como abordaremos as repetições do protagonista. Novamente adotaremos uma ordem crescente de complexidade: dedicaremos as duas seções iniciais do capítulo às ocorrências das repetições do recalcado que podemos tratar separadamente das demais recorrências formando as séries básicas da compulsão repetitiva do protagonista e as duas seções seguintes aos conflitos que, como já comentamos, as diversas repetições estabelecem entre si, começando pela consideração mais geral desses conflitos para depois tratar especificamente daqueles que formam ciclos, dentre os quais está o mais célebre fenômeno recorrente que é reconhecido pelo próprio Zeno, o dos últimos cigarros.

Finalizaremos o próximo capítulo com uma seção que dedicaremos a duas consequências de o protagonista ser construído segundo repetições que são compulsivas, ambas as quais aparecem diversas vezes no nosso corpus. A primeiras delas é intrínseca a uma compulsão: se Zeno é compelido à repetição então deve apresentar uma tendência a evitar a sua interrupção. A segunda consequência é a da interrupção das repetições, que resulta da incapacidade de satisfazer o seu comportamento compulsivo. Analisaremos como os textos do nosso corpus apresentam um resultado específico para essa incapacidade, cuja forma temporal denominamos temporalidade da nota única, que, conforme comentaremos em tal seção, deriva de uma metáfora usada numa das ocorrências desse resultado.

Como ainda mencionaremos no presente capítulo, também nomearemos outra temporalidade crucial para a nossa investigação com base numa comparação feita por Zeno. Ao recorrermos a tais empréstimos para realizar uma peculiar nomeação de 
temporalidades em detrimento de denominações teóricas mais ortodoxas, objetivamos reconhecer que uma das bases para a nossa abordagem das articulações temporais é o que avaliamos como indícios metanarrativos sobre o assunto que o próprio Svevo distribui pelos textos, principalmente no início do quinto capítulo do romance, no qual se encontram os referidos empréstimos e que consideramos uma tematização implícita de tais articulações.

Uma vez que completamos a apresentação do próximo capítulo, retomemos a exposição dos estudos de teoria literária que amparam o presente trabalho, que interrompemos ao começar a tratar da abordagem do tempo literário por Genette. No tocante às relações temporais entre a história e a narrativa, Genette se propõe a estudar:

[...] as relações entre a ordem temporal de sucessão dos acontecimentos na diegese e a ordem pseudo-temporal da sua disposição na narrativa [...]; as relações entre a duração variável desses acontecimentos, ou segmentos diegéticos, e a pseudo-duração (na realidade, extensão de texto) da sua relação na narrativa: relações, pois, de velocidade [...]; relações, enfim, de frequência, quer dizer, para nos atermos aqui a uma fórmula ainda aproximativa, relações entre as capacidades de repetição da história e as da narrativa [...]. (1987, p. 33)

Paradoxalmente, à primeira vista, as considerações do teórico sobre a frequência não são úteis para o presente trabalho. Isso ocorre porque ele se dedica a tratar das repetições reconhecidas e diversamente distribuídas entre a história e a narrativa, o que é pouco comum no que é narrado por Zeno. Assim, a aplicação da teoria elaborada por Genette sobre a frequência a esse caso estaria basicamente limitada à constatação do predomínio maciço do que chama de singulativo, no qual cada ação é única e narrada uma vez só ou é repetida e narrada a cada ocorrência.

O que será útil para a nossa análise são as relações de ordem e duração, as quais servem de critério para encontrarmos manipulações temporais, que são propícias como já assinalamos - para identificarmos incongruências narrativas que são causadas pela relação tortuosa do narrador com o passado. Além disso, não há razão para nos limitarmos aos efeitos de incongruência; de fato, devemos investigar outras influências da repetição sobre as manipulações temporais e a possibilidade simétrica de que a adoção de um padrão previamente estabelecido quanto à ordem ou à duração também esteja vinculada à repetição.

No que se refere à ordem, usaremos as seguintes noções propostas por Genette: anacronia, analepse, prolepse, silepse e acronia. Eis como ele define as três primeiras:

[...] designando por prolepse toda a manobra narrativa consistindo em contar ou evocar de antemão um acontecimento ulterior, e por analepse toda a 
ulterior evocação de um acontecimento anterior ao ponto da história em que se está, reservando o termo geral de anacronia para designar quaisquer formas de discordância entre as duas ordens temporais [da história e da narrativa]. (1987, p. 38)

No tocante às duas noções restantes, a sua apresentação é a seguinte:

[...] nenhuma inferência do conteúdo pode ajudar o analista a definir o estatuto de uma anacronia privada de toda a relação temporal, e que devemos, pois, considerar mesmo como um acontecimento sem data e sem idade: como uma acronia.

[...] poderiam chamar-se silepses (facto de agarrar no conjunto) temporais esses agrupamentos anacrônicos comandados por tal ou tal parentesco, espacial, temático ou outro. (GENETTE, 1987, p. 81-83)

No caso da relação entre as durações, não nos interessam as gradações que Genette estabelece entre o extremo de uma duração qualquer do tempo da narrativa para uma duração nula da história e o extremo simétrico a esse. Apenas nos importa que ele oferece uma medida, a velocidade da narrativa, pela qual podemos identificar as variações de tal relação:

Entende-se por velocidade a relação entre uma medida temporal e uma medida espacial [...]: a velocidade da narrativa pela relação entre uma duração, a da história, medida em segundos, minutos, horas, dias, meses e anos, e uma extensão: o [sic] do texto, medido em linhas e em páginas. A narrativa isócrona, o nosso hipotético grau zero de referência, seria, pois, uma narrativa de velocidade igual, sem acelerações nem abrandamentos, em que a relação duração de história/extensão de narrativa permanecesse constante. (1987, p. 87)

Adiantemos desde já que, ao adotarmos a abordagem geral de Genette, não propomos que nos limitemos a ela enquanto estivermos analisando os textos de Svevo, pois a passagem do plano teórico para a consideração dos casos singulares introduz a interdependência entre os mais diversos elementos do discurso, o que simplesmente não conseguiria ser abarcado exaustivamente por nenhuma teoria.

Além de Genette, a nossa principal referência teórica sobre o tempo literário, também recorreremos a outros teóricos que abordam articulações internas ao próprio tempo da história; mais precisamente, de como o presente da história se relaciona com o passado e o futuro correspondentes.

Assim, adotaremos uma contribuição do teórico Roland Barthes quanto à relação de expectativa entre o presente e o futuro da história que é estabelecida por ela mesma e pelos demais aspectos da narrativa. Sob a denominação de código hermenêutico, ele apresenta a articulação bem específica segundo a qual são elaboradas as expectativas no romance clássico; eis o que Barthes afirma sobre a dinâmica do texto 
articulado dessa maneira:

[...] é uma dinâmica estática: o problema reside em manter o enigma no vazio inicial da sua resposta; enquanto as frases apressam o "desenrolar" da história [...], o código hermenêutico exerce uma acção contrária: deve dispor, no fluxo do discurso, de demoras (ardis, pausas, desvios); a sua estrutura é essencialmente reactiva, porque opõe, ao avanço inelutável da linguagem, um jogo escalonado de paragens: entre a pergunta e a resposta desenvolve-se todo um espaço dilatório, cujo emblema poderia ser a "reticência", essa figura retórica que interrompe a frase, suspende-a e desvia-a (o Quos ego... virgiliano). De aí, no código hermenêutico, a abundância de morfemas dilatórios, comparativamente aos seus termos extremos (a pergunta e a resposta): o logro (espécie de desvio intencional da verdade), o equívoco (mistura de verdade e logro que, muitas vezes, adensando o enigma, contribui para o envolver), a resposta parcial (cuja função é exasperar a espera da verdade), a resposta suspensa (paragem afásica da revelação) e o bloqueio (constatações da insolubilidade). A variedade destes termos (o seu jogo de invenção) testemunha bem o trabalho considerável que o discurso deve realizar se quiser suspender o enigma, mantê-lo em aberto. A espera torna-se, deste modo, a condição fundadora da verdade: a verdade, dizem-nos estas narrativas, é o que está no extremo da espera. (1980, p. 61-62)

Além disso, devemos considerar uma relação mais geral entre os eventos que constituem a sequência temporal da história. Ora, o que tradicionalmente se pensa é que tal relação seja causal:

It has been argued, since Aristotle, that events in narratives are radically correlative, enchaining, entailing. Their sequence, runs the traditional argument, is not simply but causative. The causation may be overt, that is, explicit, or covert, implicit.

Consider again E. M. Forster's example (slightly altered for present purposes). Forster argues that "The king died and the queen died" is only a "story" (in the sense of a "mere chronicle"); "The king died and the queen died of grief" is a "plot", because it adds causation. (CHATMAN, 1978, p. 45)

A distinção exposta por Forster entre os dois enunciados é mais didática do que realmente efetiva, pois Barthes já destacava a que extremo se impunha a ligação entre a causalidade e a sequência narrativa:

Tudo deixa pensar, com efeito, que a mola da atividade [narrativa] é a confusão da consecução e da consequência, o que vem depois sendo lido na narrativa como causado por; a narrativa seria, neste caso, uma aplicação sistemática do erro lógico denunciado pela escolástica sob a fórmula post hoc, ergo propter hoc, que bem poderia ser a divisa do Destino, do qual a narrativa não é em suma mais que a "língua" (langue) [...]. (1972, p. 33)

Retomando a exposição de Chatman, ele conclui que os eventos na narrativa clássica "are linked to each other as cause to effect, effects in turn causing other effects, until the final effect. And even if two events seem not obviously interrelated, we infer that they may be, on some larger principle that we will discover later" (1978, p. 46).

Qualificamos de linear a temporalidade que privilegia a cronologia (nos termos 
de Genette, a concordância entre as ordens dos tempos da história e da narrativa), o código hermenêutico e a causalidade e permite superar eventuais desvios a eles no sentido de reafirmá-los.

A importância das noções de causalidade e de elaboração de expectativas para a nossa investigação não se resume ao sentido estrito no qual operam na temporalidade linear, que predominou nas narrativas clássicas; na medida em que os tempos da narrativa e narração ganham independência frente ao da história, também consideraremos as relações causais e o controle de expectativas que sejam desenvolvidos tanto internamente nesses tempos extradiegéticos quanto nas relações entre os tempos dos três aspectos da narrativa. Ainda que de modo mais pontual, também trataremos dos conteúdos das avaliações do narrador ou do protagonista que estejam baseadas em tais noções.

Voltando às considerações teóricas de Genette, apresentemos o que aproveitaremos do seu estudo sobre o tempo da narração. Comecemos pela identificação de quatro posições temporais da narração em relação à história:

Haveria, pois, que distinguir, do simples ponto de vista da posição temporal, quatro tipos de narração: ulterior (posição clássica da narrativa no passado, sem dúvida, e de muito longe, a mais frequente), anterior (narrativa predictiva, geralmente no futuro [...]), simultânea (narrativa no presente, contemporânea da acção) e intercalada (entre os momentos da acção). (1987, p. 216)

Outra relação entre os tempos da narração e da história é encontrada especialmente nas narrativas autobiográficas:

Como em toda a narrativa de forma autobiográfica, os dois actantes que Spitzer designava por erzählendes Ich (Eu narrante) e erzähltes Ich (Eu narrado) estão separados na Recherche [de Marcel Proust] por uma diferença de idade e de experiência que autoriza o primeiro a tratar o segundo com uma sorte de superioridade condescendente ou irônica [...]. (GENETTE, 1987, p. 251)

$\mathrm{Na}$ quarta seção do terceiro capítulo do presente trabalho, comentaremos como a repetição interfere nessa articulação temporalmente fundada e predominante no contexto das narrativas de forma autobiográfica.

Por fim, destaquemos a imbricação que se pode alcançar entre o momento quando o narrador escreve e aquele quando os personagens agem com um dos recursos discursivos mais abordados teoricamente a esse respeito: "no discurso indireto livre, o narrador assume o discurso da personagem, ou, se se preferir, a personagem fala pela voz do narrador, e as duas instâncias veem-se então confundidas" (GENETTE, 1987, p. 
172-173). Logo, até um mesmo segmento textual pode valer para os tempos da história e da narração - no sentido de que o enunciado vale também para o próprio momento da enunciação -, e essa característica torna esse tipo de discurso uma fonte privilegiada para analisarmos a relação entre eles.

Mediante os aportes teóricos que apresentamos, estamos em condições de delinear como investigaremos as principais temporalidades que compõem os textos narrados por Zeno nos três capítulos seguintes ao estudo preparatório da compulsão à repetição do recalcado como componente da diegese desses textos. Como pode ser verificado na exposição a seguir, baseamos essa tripartição nas diversas elaborações das articulações entre as temporalidades nas partes do nosso corpus que estão contempladas em cada um dos capítulos.

Dedicaremos o terceiro capítulo do presente trabalho aos capítulos do romance anteriores ao diário - o prefácio, o preâmbulo e a autobiografia propriamente dita - e o dividiremos em cinco seções, nas quais investigaremos tanto a presença da repetição do recalcado e da temporalidade da nota única fora da diegese quanto outras temporalidades que se articulam à compulsão à repetição. Na primeira delas, faremos uma análise introdutória sobre o rompimento da autobiografia de Zeno com a temporalidade linear, para o que recorreremos aos seus três componentes básicos, que apresentamos no embasamento teórico: a relação de ordem entre os tempos da história e da narrativa, a relação de causalidade e a articulação das expectativas segundo o código hermenêutico. Também incluiremos na nossa análise a afirmação de um tempo subjetivo pela justaposição de dois ou mais intervalos temporais por ser uma perspectiva frequentemente abordada na fortuna crítica.

$\mathrm{Na}$ segunda seção do terceiro capítulo, aprofundaremos a nossa investigação com base na consideração de que o rompimento com a temporalidade linear não é um resultado imediato da autobiografia; com efeito, adotaremos a perspectiva de Lavagetto sobre Zeno como escritor da própria história: "Vuole arrivare a capirsi. Nella 'relazione fondamentale con se stesso' è, come tutti gli uomini, un 'narratore' e si sforza di stabilire una serie di 'allorché', 'prima che' e 'dopo che”" (2000 p. 265). Assim, abordaremos os principais aspectos pelos quais os três componentes básicos da linearidade temporal ainda são adotados na autobiografia. Vinculando os resultados prévios e novamente recorrendo aos componentes mencionados, estabeleceremos que a autobiografia é constituída propriamente pelo embate entre a adoção da linearidade temporal e o rompimento com ela e, dado que a recusa da causalidade e do código 
hermenêutico resulta numa sucessão cujas conexões entre os eventos não são efetivas, usaremos uma comparação que Zeno faz da própria vida com a onda do mar para dar o nome de temporalidade de onda ao lado do embate que é contrário à linearidade. Por fim, argumentaremos que, para Zeno, o embate nunca é resolvido, mas, se abandonamos o seu ponto de vista, a autobiografia proporciona a experiência alternativa do contínuo fracasso da temporalidade linear frente à de onda.

Nas demais seções do terceiro capítulo, articularemos os resultados da segunda seção sobre o embate das temporalidades linear e de onda com os resultados do segundo capítulo sobre as temporalidades da repetição do recalcado e da nota única. Na terceira seção, investigaremos a possibilidade dessa articulação questionando, com base no resultado que obtivemos de uma experiência temporal da autobiografia que extrapola aquela da experiência imediata de Zeno, se o romance autorizaria que prosseguíssemos no sentido de superar essa experiência a ponto de até mesmo o embate temporal que a constitui se subordinar a outras temporalidades vigentes no texto.

Para responder ao referido questionamento, partiremos de um aspecto já bem estudado na fortuna crítica de Svevo, a falta de confiabilidade do narrador; por exemplo, tal aspecto é bem elaborado por Lavagetto, o qual constata que, como o livro é narrado por Zeno, Svevo nunca contrapõe "alle parole del narratore le proprie parole date come 'verità oggetiva', come documento su cui misurare gli scarti e le deviazioni di una menzogna flagrante" (LAVAGETTO, 1975, p. 222-223). Em vez de nos determos de modo geral nessa conhecida característica do narrador, exploraremos especificamente como o início do romance - o prefácio, o preâmbulo e os primeiros parágrafos do terceiro capítulo - está permeado de diversos alertas contra a credibilidade do narrador e da própria autobiografia, já que prepara o leitor ao previni-lo contra a perspectiva de Zeno, mas também coloca em dúvida se o texto fornece elementos suficientes para que possamos propor uma abordagem capaz de superar as dificuldades apresentadas. Completaremos a investigação do preâmbulo analisando o seu episódio final como responsável por sugerir uma resposta para essa dúvida ao dar indícios ao leitor de que é possível superar as várias dificuldades justamente se afastando da perspectiva de Zeno.

Finalizaremos a terceira seção pelo estudo do início do quinto capítulo do romance, no qual exploraremos os problemas narrativos que são suscitados com base nas conexões temporais do relato apresentado por Zeno e investigaremos como as repetições do recalcado que estão presentes no texto nos permitem resolvê-los, o que resulta na compulsão à repetição do recalcado como a nossa hipótese de abordagem 
para a autobiografia que nos permita superar as dificuldades geradas pela perspectiva de Zeno.

$\mathrm{Na}$ quarta seção do terceiro capítulo, finalmente estaremos em condições de completar, ao menos para a autobiografia contida no romance, o estudo que iniciamos no capítulo preparatório do presente trabalho abordando toda a complexidade que as repetições do recalcado do narrador agregam ao se relacionar com as do protagonista. Para isso, mobilizaremos as noções da teoria literária que expusemos a fim de analisar a operação das recorrências do recalcado de Zeno nos mais variados aspectos temporais da narração, da narrativa e até mesmo da história, tais como: ações no tempo da narração; intervenções do narrador pelas quais ele pode repetir tanto de modo convergente ao protagonista, mesmo que se trate de uma vivência própria a este, quanto de modo divergente, ainda que a diferença entre os regimes repetitivos das duas instâncias narrativas permaneça implícita; compartilhamentos de enunciados em discurso indireto livre entre as repetições do protagonista e do narrador, mesmo que elas sejam divergentes; introduções implícitas de elementos próprios ao tempo da narração, inclusive causando distorções silenciosas na história; interferência velada na ordem temporal da história por inversão cronológica; e interferências diversas na constituição do tempo da narrativa determinando, por exemplo, a seletividade da recordação, a condução das expectativas, a velocidade da narrativa, o grau de articulação em termos da ordem temporal e da causalidade, as seleções do próximo episódio numa silepse temática e o desvio da ordem cronológica pelo uso de inversões.

Na quinta e última seção do terceiro capítulo, completaremos a investigação sobre a autobiografia contida no romance tratando dos seus principais aspectos referentes às articulações da compulsão à repetição do recalcado com as temporalidades linear e de onda. Começaremos pela análise dessas articulações. Quanto à temporalidade linear, apresentaremos argumentos de que ela contribui para evitar o reconhecimento do que foi recalcado, o que é requerido pela própria noção de recalque; o principal deles será o de que ela é ordenada inversamente à ordem temporal das recordações do que foi recalcado, que, conforme uma citação que fizemos no início do embasamento teórico, Freud constatou que é cronologicamente invertida. No tocante à temporalidade de onda, exploraremos tanto a sua participação na articulação anterior por meio do fracasso de se estabelecer uma narrativa linear devido à própria compulsão à repetição quanto relações mais diretas que se estabelecem por meio das repetições do narrador que perturbam o fluxo da história ou pelos apelos de Zeno a uma figura de 
oposição à causalidade, seja como recurso extremo a uma causalidade desprovida de valor cognitivo, tal como a superstição, seja para evitar o reconhecimento da natureza repetitiva de algum acontecimento.

Finalizaremos a quinta seção expondo as críticas que são implicadas pelas articulações que investigamos e abordando as diferenças entre o terceiro capítulo do romance e os demais capítulos que compõem a autobiografia, principalmente a especificidade das articulações elaboradas no terceiro capítulo, no qual a identificação das repetições é promovida pela predominância da silepse temática e pela ausência de divergências entre as repetições do protagonista e do narrador.

Dividiremos o quarto capítulo do presente trabalho em quatro seções e o dedicaremos ao último capítulo, escrito como um diário, e ao âmbito global do romance, dos quais investigaremos as transformações da repetição do recalcado e das articulações temporais que apresentamos no segundo e no terceiro capítulos do presente trabalho. Assim, ele será a etapa conclusiva do nosso estudo do romance. Na primeira seção, exporemos em que medida o que Zeno registrou nas duas datas iniciais do diário, principalmente na primeira, opera com a repetição do recalcado tal como na autobiografia, apesar das diferenças causadas pela novidade do contexto clínico dado pelas sessões de Zeno com o psicanalista.

Na segunda seção, trataremos da primeira cura parcial de Zeno, que consiste no fim de algumas repetições do recalcado, conforme podemos reconhecer no que está registrado na segunda data do diário, e das consequências dessa cura para o registro feito na primeira data e para o diário como um todo, principalmente o abandono implícito da temporalidade linear por Zeno, a qual permanece apenas de modo residual, e a própria mudança da escrita autobiográfica para diarística que decorre de tal abandono.

$\mathrm{Na}$ terceira seção, investigaremos a segunda cura parcial de Zeno, que consiste no fim das repetições do recalcado que ainda permaneceram após a primeira cura, conforme podemos reconhecer no registro feito na última data do diário, e as consequências imediatas dessa cura para o mesmo registro, principalmente o fim da temporalidade da nota única, dado que Zeno não está mais submetido à compulsão à repetição, e a mudança da escrita de um diárío privado para uma carta hostil ao psicanalista.

Na última seção do quarto capítulo, abordaremos o âmbito global do romance de modo a confirmarmos o fim das articulações temporais que vigoravam na 
autobiografia e a identificarmos as mudanças provocadas pelas duas curas parciais que determinam a ação e o ato da escrita na carta que encerra o romance, dentre as quais está a gradação temporal que encontramos na escrita de Zeno ao considerá-la segundo as quatro posições temporais da narração em relação à história que são propostas por Genette.

Por fim, dedicaremos o quinto capítulo do presente trabalho às "continuações", para as quais ele completará o estudo iniciado no segundo capítulo tal como o terceiro e o quarto capítulos completam tal estudo no que tange ao romance. Assim, investigaremos as três transformações da compulsão à repetição de Zeno nos textos das “continuações" e como as principais relações entre os tempos da história, da narrativa e da narração desses textos são elaboradas segundo a repetição do recalcado.

Dividiremos o quinto capítulo em cinco seções. Na primeira, analisaremos como a história do texto Un contratto expõe a primeira das três transformações da compulsão à repetição de Zeno, a qual consiste na sua recaída nessa compulsão na medida em que o protagonista volta a apresentar tanto as repetições do recalcado que haviam terminado devido à segunda cura parcial quanto a temporalidade da nota única, que havia terminado devido ao fim de todas as recorrências do recalcado. Também consideraremos a história dos demais textos das "continuações" para tratar das limitações dessa recaída e para verificar em que medida as repetições do recalcado que voltaram na recaída continuam ocorrendo e as demais não voltam a ocorrer.

$\mathrm{Na}$ segunda seção, investigaremos os principais aspectos da articulação entre os tempos da história e da narrativa em cada uma das "continuações" e apresentaremos a segunda transformação da compulsão, a inibição das repetições do recalcado do protagonista, a qual é crucial para um desses aspectos. Aproveitaremos que essa investigação exigirá uma abordagem minuciosa dos textos para identificar os trechos que tratam da história entre a segunda cura parcial de Zeno e a sua recaída nas repetições do recalcado e para verificar se esses trechos efetivamente não apresentam repetições compulsivas como componentes relevantes da ação do protagonista.

$\mathrm{Na}$ terceira seção do capítulo final, estudaremos tanto a constituição de Zeno como escritor autobiográfico como reação à consolidação da velhice e da temporalidade da nota única à medida que as repetições do recalcado são inibidas quanto a relação da escrita de Zeno com a última das três transformações, a retomada das repetições que estão inibidas no protagonista.

Dedicaremos a quarta seção à análise de como Zeno, ao retornar à escrita 
autobiográfica, efetivamente retoma as repetições inibidas por meio da atividade narrativa, o que faremos investigando as maneiras pelas quais os tempos da narrativa e da narração são construídos de modo que Zeno como narrador retome as repetições do recalcado que estão inibidas no final do tempo da história.

Na quinta seção, identificaremos o limite da retomada das repetições inibidas pela escrita e exploraremos as suas consequências principais para os tempos da narração e da narrativa, as quais decorrem da incorporação desse limite aos trechos nos quais Zeno não se dedica a narrar a própria vida e, retomando o estudo que fizemos na segunda seção, à articulação entre os tempos da história e da narrativa. Por fím, formularemos uma proposta para essa articulação com base no contraste entre o romance e as "continuações" no que se refere ao exercício das repetições do recalcado fora do âmbito da escrita.

Uma vez que apresentamos a complexa investigação que propomos realizar a partir do próximo capítulo, acrescentemos breves comentários que servem como uma avaliação prévia do tipo de escrita que consideramos ser praticada pelo narrador Zeno e pelo romancista Svevo nos textos do nosso corpus.

Quanto a Zeno, nos afastamos das avaliações segundo as quais a escrita seria um processo de autoconstituição do sujeito ou o instrumento pelo qual ele supera as limitações da velhice ou a doença - no último caso, em detrimento de uma psicanálise a ser criticada -; pelo contrário, consideramos que, em geral, ela opera como um instrumento da compulsão à repetição do recalcado de Zeno e, como tal, garante que o narrador permaneça tão doente e ignorante de si mesmo quanto ao começar a narrar e, especificamente no caso do romance publicado, contribui para o fracasso da terapia psicanalítica.

No tocante a Svevo, consideramos que a sua escrita, algumas vezes pouco valorizada em termos de inovação, opera como um experimento artístico sobre a temporalidade literária no qual explora as mais variadas relações temporais a partir da repetição compulsiva do recalcado. Especificamente no caso do romance publicado, também consideramos que há uma crítica à narrativa tradicional: ao fazer com que o narrador tente escrever segundo as convenções da época, mas continuamente fracasse nessa tentativa, Svevo faria uma crítica irônica e metanarrativa à própria possibilidade de ainda se produzir narrativas tradicionais, pelo menos nas condições do protagonistanarrador que ele criou. 


\section{Capítulo 2 \\ A REPETIÇÃO DO RECALCADO COMO COMPONENTE DA DIEGESE DOS TEXTOS NARRADOS POR ZENO}

Dedicaremos o presente capítulo à análise do tempo da história do romance $L a$ coscienza di Zeno e das "continuações" na medida em que está constituído em ambos pela compulsão à repetição do recalcado. Restringir de tal modo a abordagem inicial deste trabalho traz duas vantagens para a nossa investigação, das quais a primeira é a oportunidade para demarcarmos com clareza a diferença de alcance que a nossa leitura dá à repetição frente ao que encontramos nos estudos sobre Svevo. Conforme comentamos no capítulo anterior, os críticos só tratam dela no tocante ao romance e a limitam basicamente aos sintomas do protagonista e àquelas manifestações reconhecidas pelo enredo; neste capítulo, por sua vez, argumentamos que ela é igualmente relevante nas "continuações", se manifesta de múltiplas maneiras que não são reconhecidas pelo enredo e é a base para fenômenos cruciais do comportamento relatado do protagonista, como a oscilação entre duas ações e o esforço desmedido para evitar a interrupção de uma situação.

A segunda vantagem da abordagem que adotamos é o esclarecimento do nosso entendimento básico dos acontecimentos narrados, dado que a multiplicidade de interpretações vigentes sobre eles na volumosa fortuna crítica sobre Zeno poderia causar, sem tal alinhamento prévio, várias incompreensões sobre a argumentação que desenvolveremos a partir deles ao longo do presente trabalho.

Como restrição adicional ao escopo do presente capítulo, evitaremos o tempo da história do diário que encerra o romance devido ao contexto clínico que lhe é próprio e do qual trataremos no quarto capítulo deste trabalho.

Logo, apesar de este capítulo abordar quase toda a história de Zeno nos textos do nosso corpus, ele é apenas uma etapa preparatória da nossa investigação, de modo que a nossa abordagem só estará completa no terceiro capítulo no que se refere à parte do romance que antecede o diário e no quinto capítulo no que tange às "continuações".

Elaboraremos a relação entre a noção psicanalítica da compulsão à repetição do recalcado e a criação literária neste capítulo com base na construção do protagonista e na linguagem empregada por Zeno como componente importante dessa construção.

Antes de começarmos a investigar propriamente a presença da repetição nas 
diegeses dos textos do nosso corpus, faremos uma breve menção a alguns trechos do romance que servem de indícios gerais de que Zeno, como personagem e narrador, é construído conforme a noção de compulsão à repetição do recalcado, que já apresentamos no capítulo anterior. Ela implica que Zeno não recorde o que recalcou, mas repita-o sem que isso o retire do esquecimento.

No tocante à repetição, há, no capítulo sobre o fumo, dois trechos nos quais o narrador reconhece a presença desse fenômeno ao relatar a própria vida, ainda que em termos bastante vagos, dos quais o primeiro é "Eppoi il tempo, per me, non è quella cosa impensabile che non s'arresta mai. Da me, solo da me, ritorna"1 $(2004$, p. 635) e o segundo é "Non si può mai conoscere il futuro. Da me le cose si ripetono" (2004, p. 651). ${ }^{2}$ A referência ao contexto imediato são os últimos cigarros, mas justamente as formulações indeterminadas deixam uma abertura para a interpretação, o que é muito conveniente para a nossa proposta de uma repetição de algo que continua esquecido. Ademais, o problema da recordação também é abordado pelo próprio narrador, como o crítico Eduardo Saccone já destacava com afirmações pertencentes às primeiras páginas dos capítulos quarto e quinto: "Ricordo tutto, ma non intendo niente'. E' la dichiarazione folgorante di Zeno che racconta dei suoi rapporti col padre. $\mathrm{O}$, in altro luogo, narrando la storia del suo matrimonio: 'Io sto raccontando una storia che non conosco bene"” (1973, p. 11-12). A essas podemos ainda acrescentar outras, como a seguinte fala do protagonista: "- Non lo so più, ma ignoro anche tante altre cose della mia vita"3 (2004, p. 694). Aproveitemos para observar que nessas citações Zeno também se declara incapaz de entender a própria história.

\subsection{As séries básicas de repetição: o desejo pela mãe}

Tendo as declarações mais gerais de Zeno que apresentamos como um primeiro indício de comprovação de que a compulsão repetitiva é um dos componentes da construção do protagonista-narrador, continuemos a explorar essa noção psicanalítica

\footnotetext{
${ }^{1}$ Além disso, o tempo para mim não é essa coisa insensata que nunca para. Para mim, só para mim, ele retorna (2006, p. 21).

${ }^{2}$ Não se pode prever o futuro. Comigo as coisas costumam repetir-se (2006, p. 36).

3 - Nem sei mais. Há tantas coisas que ignoro sobre minha vida (2006, p. 75).
} 
ampliando - como hipótese a ser verificada - o seu alcance também para as "continuações". Ademais, o que o doente repete é aquilo que recalcou e devemos, portanto, descobrir o que Zeno recalcou. Na verdade, o diagnóstico de Zeno é determinado pelo próprio romance, dado pelo seu psicanalista, o doutor S.: trata-se do hoje célebre complexo de Édipo. Por algumas razões, se poderia duvidar da correção do diagnóstico, mas assumiremos que está correto, pois o próprio prosseguimento do presente trabalho, tanto neste capítulo quanto nos próximos, ratificará (ou desmintiria, se estivesse errado) o nosso parecer. Enfim, se o doutor S. diagnosticou corretamente o seu paciente, é óbvio, após a ampla divulgação que teve a psicanálise na cultura ocidental, que Zeno recalcou o desejo pela mãe e a rivalidade contra o pai.

Assim, identificaremos as séries das múltiplas repetições do recalcado em Zeno tendo por base a investigação das características que o romance fornece para os dois componentes do recalque edipiano. Dedicamos a presente seção do capítulo ao componente materno, sobre o qual o principal trecho é o último sonho relatado por Zeno ao doutor S.:

[...] ebbi un sogno dall'immobilità dell'incubo. Sognai di me stesso ridivenuto bambino e soltanto per vedere quel bambino come sognava anche lui. Giaceva muto in preda ad una letizia che pervadeva il suo minuto organismo. Gli pareva di aver finalmente raggiunto il suo antico desiderio.

[...] Il bambino, giacendo in una stanza della mia villa, vedeva (Dio sa in quale modo) che sul tetto della stessa ci fosse una gabbia murata su basi solidissime, priva di porte e di finestre, ma illuminata di quanta luce può far piacere e fornita di aria pura e profumata. Ed il bambino sapeva che a quella gabbia egli solo avrebbe saputo giungere e senza neppur andare perché forse la gabbia sarebbe venuta a lui. In quella gabbia non v'era che un solo mobile, una poltrona e su questa sedeva una donna formosa, costruita deliziosamente, vestita di nero, bionda, dagli occhi grandi e azzurri, le mani bianchissime e i piedi piccoli in scarpine laccate delle quali, di sotto alle gonne, sporgeva solo un lieve bagliore. Devo dire che quella donna mi pareva una cosa sola col suo vestito nero e le sue scarpine di lacca. Tutto era lei! Ed il bambino sognava di possedere quella donna, ma nel modo più strano: Era sicuro cioè di poter mangiarne dei pezzettini al vertice e alla base. ${ }^{4}(2004$, p. 1055)

\footnotetext{
${ }^{4}$ [...] tive um sonho em que havia a imobilidade dos pesadelos. Sonhei que voltara a ser criança para descobrir como eu sonhava em pequeno. Jazia mudo, presa de uma alegria que penetrava o meu minúsculo organismo. Parecia-me haver finalmente alcançado o meu antigo desejo.

[...] A criança, deitada num quarto da minha casa, via (Deus sabe como) que sobre o telhado da mesma havia uma prisão construída sobre bases muito sólidas, desprovida de portas e janelas, mas iluminada por quanta luz se possa imaginar e abastecida de ar puro e perfumado. O menino sabia que somente ele era capaz de chegar àquela masmorra, e para tanto nem precisava andar, pois ela podia vir a ele. Em seu interior só havia um móvel, uma poltrona, na qual se achava sentada uma bela mulher, de formas delicadas, vestida de negro, loura, com grandes olhos azuis, as mãos alvíssimas, e os pequenos pés metidos em sapatos de verniz, dos quais, por baixo do vestido, se via apenas um leve reflexo. Devo dizer que essa mulher constituía para mim um todo, com seu vestido preto e seus sapatos de verniz. Ela era tudo! E o menino sonhava possuir a mulher, da maneira mais estranha possível: estava certo de que podia comê-la aos pedacinhos desde o vértice até a base (2006, p. 395).
} 
Por um lado, a ausência de nomeação de uma mulher tão intensamente desejada é um forte indício de se tratar de algo recalcado; por outro lado, a sua identificação como a mãe do protagonista não oferece dificuldades, dado que Zeno ainda é uma criança no sonho e não há outra mulher que seja mencionada no romance como tendo importância comparável à da mãe para a sua infância. O único trecho que poderia ser efetivamente contraposto à nossa argumentação seria o que sugere que esse sonho seria uma variação daquele com a amante Carla, mas exploraremos, no quarto capítulo, o contexto específico no qual tal sugestão é produzida e que desqualifica a sua função de objeção à identificação mencionada.

Destaquemos as características do desejo pela mãe que estão expressas oniricamente e que usaremos na identificação das suas repetições: o canibalismo, num grau tal que o sonhador cogita comer inteiramente a mulher desejada; o fetichismo, fenômeno pelo qual partes do corpo ou da indumentária se tornam substitutas do objeto sexual; a unidade do objeto desejado, inclusive com o vestido e os sapatos (o que cria uma tensão com a característica fetichista); e também a totalidade, uma vez que é afirmado que a mulher é tudo para o sonhador.

No romance, as relações afetivas e eróticas de Zeno com as mulheres repetem sempre uma ou mais características que destacamos da relação com a mãe (a situação é diferente nas "continuações", conforme comentaremos ao abordar o fetichismo). Comecemos a determinar a abrangência dessas repetições por um trecho de grande ressonância com o sonho citado, no qual o protagonista, ainda jovem, descreve o que entende como o seu problema com as mulheres para um médico:

\footnotetext{
Fui sincero come in confessione: La donna a me non piaceva intera, ma... a pezzi! Di tutte amavo i piedini se ben calzati, di molte il collo esile oppure anche poderoso e il seno se lieve, lieve. E continuavo nell'enumerazione di parti anatomiche femminili, ma il dottore m'interruppe:

- Queste parti fanno la donna intera.

Dissi allora una parola importante:

- L'amore sano è quello che abbraccia una donna sola e intera, compreso il suo carattere e la sua intelligenza.

Fino ad allora non avevo certo conosciuto un tale amore e quando mi capitò non mi diede neppur esso la salute. ${ }^{5}(2004$, p. 638$)$
}

\footnotetext{
${ }^{5}$ Fui sincero como se me confessasse: a mulher não me atraía como um todo, mas... fragmentariamente. Em todas apreciava os pezinhos bem calçados; em muitas o colo delicado ou mesmo portentoso; e sempre os seios pequenos, pequeninos. E continuava enumerando as partes anatômicas femininas, quando o doutor me interrompeu:

- Estas partes formam uma mulher inteira.

Disse então algo importante:

- O amor saudável é aquele que se resume numa mulher apenas, íntegra, inclusive de caráter e inteligência.

Até então eu não conhecera tal amor e, quando este me sobreveio, nem mesmo ele conseguiu restaurarme a saúde (2006, p. 24).
} 
Assim, a citação inicia com o fetichismo, e depois o protagonista define o amor são justamente pela unidade e totalidade, cuja falta nas suas relações com as mulheres ele desejaria suprimir. Além das citações anteriores, a unidade e a totalidade só são repetidas com Ada, como, por exemplo, quando conclui que a ama (2004, p. 722). Logo, essas duas características são elementos distintivos entre a relação com Ada e com as demais mulheres da vida adulta de Zeno.

A série de repetição do fetichismo é a mais longa daquelas baseadas no desejo pela mãe. Além dos trechos que já citamos, a série se faz presente na relação de Zeno com Alberta (2004, p. 866) e com cada uma das três principais mulheres da sua vida erótica na maturidade - Ada (2004, p. 709), Augusta (2004, p. 644) e Carla (2004, p. 813 ) - por meio da referência às partes do corpo, principalmente os pés.

Ainda há uma referência geral ao fetichismo que sugere que ele continuou a orientar a relação de Zeno com as mulheres até a época do narrador, pois já pertence ao diário iniciado em 1915: "La donna vi [na vida e na doença de Zeno] ebbe un'importanza enorme. Magari a pezzi, i suoi piedini, la sua cintura, la sua bocca, riempirono i miei giorni."6 (2004, p. 1066).

Por fim, ainda encontramos o fetichismo no texto Umbertino - inclusive com a parte predileta, os pés -, mais exatamente, no episódio de Bigioni, um pretendente da filha Antonia:

Egli [Bigioni] addirittura non s'accorgeva che a questo mondo vi fossero altre donne fuori di Antonia. Bastava camminare con lui per le vie per accorgersene. Non vedeva le tante gambe nude che vi erano esibite abbellite dalla seta.

[...] pensai a quella donna unica che poteva soddisfare il desiderio di un uomo, fatta in quelle date dimensioni, munita di quel sorriso, di quel suono di voce, di quel modo di vestire che l'accompagna anche quando essa è nuda.

[...] E pensai ad una donna bella e grande [...] che incontro talvolta e per la quale m'assoggetto persino ad inforcare gli occhiali per veder meglio da lontano: Tutta un'armonia, una forza, un'abbondanza di forme senz'eccesso, il piede non piccolo però ben calzato e la caviglia piccola in proporzione. Insomma una donna che può apparire unica per più o meno lungo tempo. (2004, p. 1174-1176)

É importante reparar que o trecho termina com Zeno afirmando que a mulher desejada é única apenas durante um determinado tempo, o que contradiz uma das características do desejo pela mãe que estamos estudando. Na verdade, o trecho citado é excepcional no que se refere às "continuações", pois não encontramos outras repetições

\footnotetext{
${ }^{6} \mathrm{O}$ encanto feminino encheu a minha existência. Ainda que pouco a pouco [sic], uns pezinhos, uma cintura, uma boca povoaram os meus dias. (2006, p. 405).
} 
do desejo pela mãe nesses textos. Por ora, ficaremos restritos a esses comentários, uma vez que só estaremos em condições de esclarecer essa situação no último capítulo, após havermos tratado, no quarto capítulo, das curas parciais de Zeno nas páginas finais do romance.

Passemos à série do canibalismo, cuja principal ocorrência é o sonho com Carla, que está prestes a se tornar a sua amante. O canibalismo é expresso de modo bastante parecido ao do sonho com a mãe:

Ebbi un sogno bizzarro: non solo baciavo il collo di Carla, ma lo mangiavo. Era però un collo fatto in modo che le ferite ch'io le infliggevo con rabbiosa voluttà non sanguinavano, e il collo restava perciò sempre coperto dalla sua bianca pelle e inalterato nella sua forma lievemente arcuata. Carla, abbandonata fra le mie braccia, non pareva soffrisse dei miei morsi. Chi invece ne soffriva era Augusta che improvvisamente era accorsa. Per tranquillarla le dicevo: "Non lo mangerò tutto: ne lascerò un pezzo anche a te". ${ }^{7}(2004$, p. 825$)$

Na verdade, a única presença da série do canibalismo em si de importância comparável ao sonho com a mãe está no relacionamento com Carla, do qual é um dos elementos mais abrangentes, dado que a história com a amante é pontuada do início ao fim por várias expressões canibalescas, especialmente ligadas aos dentes: desde a reação hostil de Zeno ao comentário de Copler de que ela não é comida para os dentes deles (2004, p. 807) até fincar os dentes nos lábios para tentar cessar os pensamentos sobre a amante perdida (2004, p. 908).

O canibalismo é o fenômeno mais extremo do componente oral da sexualidade de Zeno. Que ele não seja o único podemos comprovar por meio de outra repetição importante desse componente no episódio do jogo na bolsa de valores após o suicídio de Guido, no qual há cinco ocorrências do verbo "succhiellare". Citemos a primeira e a última delas: "Ho la curiosa sensazione nel mio ricordo che ininterrottamente, per cinquanta ore, io fossi rimasto assiso al tavolo da giuoco succhiellando le carte" ${ }^{\prime 8}$ (2004, p. 1034) e "Non credevo più nel giuoco di Borsa o almeno mi mancava la fiducia che il

\footnotetext{
7 Tive um sonho curioso: não só beijava o pescoço de Carla, mas ainda o comia. Contudo, era um tal pescoço que não sangravam as feridas que eu lhe infligia com selvagem volúpia, e por isso permanecia sempre coberto por sua pele branca e inalterado na sua forma levemente recurva. Carla, abandonada entre meus braços, não

parecia sofrer com as mordidas. Em vez dela, sofreu-as Augusta, que surgiu de improviso. Para tranquilizá-la, eu lhe dizia: "Não comerei tudo; deixarei um pedaço para você" (2006, p. 192).

8 Tenho a curiosa sensação, em minha lembrança, de haver permanecido à mesa de jogo, ininterruptamente, por cinquenta horas, "chorando as cartas" [perde o sentido oral da palavra italiana] (2006, p. 376).
} 
mio 'succhiellare' potesse regolarne l'andamento"" (2004, p. 1045). O verbo é usado em referência às cartas de jogo, uso no qual tem o sentido de descobri-las lentamente para saborear a emoção de ser beneficiado pela sorte. Tal sentido seria suficiente se o protagonista se arriscasse a jogar na bolsa de valores apenas por ser viciado em apostar dinheiro ou pelo próprio ganho financeiro, mas não é este o caso, pois o principal objetivo para a sua arriscada atitude é prosseguir na tarefa de conquistar a mulher desejada: como Ada mesmo compreende (2004, p. 1042), Zeno, ao recuperar boa parte do prejuízo por meio da especulação na bolsa de valores, faz com que o motivo do suicídio de Guido deixe de existir, privando-o de sentido, e, portanto, de modo a deixar o caminho para Ada livre de qualquer comprometimento por parte dela com o falecido marido devido ao seu ato desesperado. É o fato de estar agindo em prol do seu desejo pela cunhada que tornam relevantes as relações semânticas do verbo "succhiellare" fora da expressão à qual está ligado no texto: ele é derivado do verbo "succhiare" ("sugar" ou "chupar") e significa saborear (regionalismo toscano), o que o torna apropriado para expressar o componente oral da sexualidade de Zeno nesse momento crítico do seu desejo por Ada.

Além do último sonho relatado por Zeno, há mais dois trechos do romance que fornecem características importantes do componente materno do recalque edipiano: o sonho da ida à escola e o sorriso da mãe. Sobre o sonho diz a crítica Teresa de Lauretis: "l'invidia per il fratello minore, a cui è permesso restare a casa, è la causa del 'passo rilutante' di Zeno bambino mentre viene accompagnato a scoula, e stabilisce il legame tra difficoltà nel camminare, gelosia della madre e invidia verso il fratello" (1976, p. 106). O protagonista reage ao afastamento forçado da mulher desejada por meio do passo relutante, o qual será objeto de repetições na forma do ato de mancar, que é identificado como um sintoma por Lauretis: "nelle memorie di Zeno la prima volta che egli si mette a zoppicare è quando gli viene chiesto di non frequentare più casa Malfenti, e che questo sintomo nevrotico si fa particolarmente acuto in presenza di Guido" (1976, p. 106). Assim, Zeno começa a mancar durante os dias nos quais é obrigado a ficar longe de Ada (2004, p. 731), claudica algumas vezes no dia que conhece Guido (2004, p. 736-752), que o separa dela, e também manca uma vez após Carla romper com ele (2004, p. 895).

Para terminarmos a análise das séries de repetição do recalcado materno,

\footnotetext{
${ }^{9}$ Não acreditava mais no jogo da Bolsa ou pelo menos me faltava confiança de que minha especulação [perde o sentido oral da palavra italiana] pudesse regular seu andamento (2006, p. 386).
} 
abordemos o trecho do sorriso da mãe:

Mio padre con voce bassa si lamentò:

- Io credo di diventar matto. Sono quasi sicuro di aver lasciato mezz'ora fa su quell'armadio un mezzo sigaro ed ora non lo trovo più. Sto peggio del solito. Le cose mi sfuggono.

Pure a voce bassa, ma che tradiva un'ilarità trattenuta solo dalla paura di destarmi, mia madre rispose:

- Eppure nessuno dopo il pranzo è stato in quella stanza.

Mio padre mormorò:

- È perché lo so anch'io, che mi pare di diventar matto!

Si volse ed uscì.

Io apersi a mezzo gli occhi e guardai mia madre. Essa s'era rimessa al suo lavoro, ma continuava a sorridere. Certo non pensava che mio padre stesse per ammattire per sorridere così delle sue paure. Quel sorriso mi rimase tanto impresso che lo ricordai subito ritrovandolo un giorno sulle labbra di mia moglie. ${ }^{10}$ (2004, p. 630-631)

Qualquer que seja a causa pela qual a mãe sorri, o resultado para Zeno, que fumou o charuto que o pai procura, é que o sorriso marca a cumplicidade dela com a realização do seu desejo e com a privação do desejo do marido em favor do desejo de outro. A própria citação termina com a repetição do sorriso materno em Augusta, mas não esclarece qual dos dois aspectos é repetido. Abordemos um exemplo que mostra que ambos se repetem, mas em situações diferentes:

Ma quel giorno ebbi un violento litigio con Augusta. Si trattava di cosa da poco. Io dicevo che la minestra era troppo salata ed essa pretendeva di no. Ebbi un accesso folle d'ira perché mi sembrava ch'essa mi deridesse e trassi a me con violenza la tovaglia così che tutte le stoviglie dalla tavola volarono a terra.

[...] Quand'io mitemente mi misi a domandarle scusa, essa volle spiegare una cosa: non aveva riso, aveva soltanto sorriso nello stesso modo che m'era piaciuto tante volte e che tante volte avevo vantato.

[...] Avevo ripetutamente domandato scusa perché dovevo indurre Augusta di ritornare al suo sorriso materno quando dicevo o facevo delle bizzarrie. Guai [...] se avesse dovuto sopprimere anche uno dei soliti suoi sorrisi affettuosi che mi parevano il giudizio più completo e benevolo che si potesse dare su me. ${ }^{11}(2004$, p. $897-898)$

\footnotetext{
${ }^{10}$ Ele pôs-se a lamentar com voz baixa:

- Devo estar maluco. Estou quase certo de ter deixado ainda há pouco um charuto apagado em cima daquela cômoda e não consigo encontrá-lo. Estou cada vez pior. Não me lembro de nada.

Também em voz baixa, mas que traía uma hilaridade contida apenas pelo temor de despertar-me, minha mãe respondeu:

- E olha que ninguém esteve aqui na sala depois do almoço.

Papai murmurou:

- Exatamente por isso acho que estou doido!

Voltou-se e saiu.

Entreabri os olhos e espreitei minha mãe. Ela havia voltado a atenção à costura, mas continuava a sorrir. Decerto não achava que papai fosse a ponto de estar doido para sorrir assim de seu temor. Aquele sorriso me permaneceu de tal forma impresso na lembrança que um dia o revi nos lábios de minha mulher (2006, p. 17-18).

${ }^{11}$ Nesse dia, porém, tive uma violenta altercação com Augusta. Tratava-se de coisa de pouca importância. Eu dizia que a sopa estava salgada e ela afirmava o contrário. Tive um acesso imbecil de irritação porque me pareceu que ela zombava de mim e puxei com toda a violência a toalha da mesa, fazendo cair por terra a louça.
} 
Com base no fim da citação, somos induzidos a concluir que o sorriso da esposa normalmente parece repetir a cumplicidade do sorriso materno - retomaremos essa questão ainda neste capítulo -, mas isso não ocorre na discussão narrada porque o protagonista sofre com a perda da amante para outro (o que não é explicitado), de modo que associa o sorriso de Augusta para ele com o outro aspecto do sorriso da mãe, aquele que zomba da privação do desejo do marido.

\subsection{As séries básicas de repetição: a rivalidade contra o pai}

Uma vez que identificamos as séries de repetições do desejo pela mãe, investiguemos as características fornecidas para o componente paterno do recalque edipiano de Zeno e, com base nelas, identifiquemos as séries da rivalidade contra o pai. Antes de começarmos, ressaltemos que não temos nenhuma intenção de sermos exaustivos nessa investigação, pois as mais variadas expressões de oposição poderiam ser mencionadas a esse respeito. Logo, nos limitaremos a expor as principais e mais abrangentes dentre tais séries.

A característica mais óbvia do componente paterno do recalque edipiano, mas que precisamos abordar devido à grande importância que possui na relação de Zeno com quase todos os principais personagens masculinos, é a competição sexual. A competição de pai e filho pela mãe está expressa no sonho da tinta derrubada:

\footnotetext{
Mio padre è ritornato a casa e siede su un sofà accanto a mamma che sta imprimendo con certo inchiostro indelebile delle iniziali su molta biancheria distribuita sul tavolo a cui essa siede. Io mi trovo sotto il tavolo dove giuoco con delle pallottole. M'avvicino sempre più a mamma. Probabilmente desidero ch'essa s'associ ai miei giuochi. A un dato punto, per rizzarmi in piedi fra di loro, m'aggrappo alla biancheria che pende dal tavolo e allora avviene un disastro. La boccetta d'inchiostro mi capita sulla testa, bagna la mia faccia e le mie vesti, la gonna di mamma e produce una lieve macchia anche sui calzoni di papà. Mio padre alza una gamba per appiopparmi un
}

[...] Quando humildemente comecei a pedir-lhe desculpas, ela só quis explicar uma coisa: não havia rido; apenas sorrira daquela forma que tanto me agradava e que eu tantas vezes havia gabado.

[...] Pedi reiteradas desculpas a Augusta, a fim de induzi-la a reaver aquele sorriso maternal de quando eu dizia ou cometia extravagâncias. Que desagradável [...] se tivesse que privar-se de um dos seus habituais sorrisos afetuosos, que me pareciam o mais completo e benévolo dos juízos que se poderia fazer a meu respeito (2006, p. 254-255). 
calcio... ${ }^{12}(2004$, p. 1054)

O desejo da criança de se colocar entre os pais é explícito - a ponto de podermos conjecturar que mesmo o acidente talvez seja equivalente a um ato falho, pois Zeno interrompe a atividade materna de reproduzir as iniciais dos pais - e o conteúdo sexual está distorcido por símbolos analisados por Freud no seu estudo sobre os sonhos (1987a): a mesa, a associação entre "mesa" e "cama" favorecida pela palavra "biancheria", que é usada em associação com as duas divisões da vida doméstica, e a tinta derrubada, que serve para simbolizar a ejaculação.

A série da competição sexual prossegue com o irmão, também pela mãe, por meio dos sonhos da ida à escola (2004, p. 1051-1052), dedicado à disputa implícita pela companhia da mãe, e da colher. Este sonho, tal como o da tinta derrubada, distorce o conteúdo sexual com símbolos oníricos analisados por Freud (1987a): a colher, como todos os objetos alongados, e o nariz são símbolos fálicos, e a xícara, como todos os recepientes, simboliza o órgão sexual feminino. Dada a estreita ligação com a relação com o concunhado Guido, conforme comentaremos ao tratar dele na série em análise, citemos o segundo sonho:

[...] io mi trovavo tuttavia nel mio letto con in mano una tazza da cui avevo sorbito tutto il caffelatte e nella quale continuavo a lavorare con um cucchiaino traendone lo zucchero. Ad un certo punto il cucchiaio non arrivò più a raccoglierne altro ed allora io tentai di arrivare al fondo della tazza con la mia lingua. Ma non vi riuscii. Perciò finii col tenere la tazza in una mano e il cucchiaio nell'altra e stetti a guardare mio fratello coricato nel letto accanto al mio come, tardivo, stava ancora sorbendo il caffè col naso nella tazza. [...] Il suo viso era pallido ed un pouco imbruttito da un lieve prognatismo. Mi disse:

- Mi presti il tuo cucchiaio?

Allora appena m'avvidi che Catina aveva dimenticato di portargli il cucchiaio. Subito e senz'alcuna esitazione gli risposi:

- Sì! Se mi dai in compenso un poco del tuo zucchero.

Tenni in alto il cucchiaio per farne rilevare il valore. ${ }^{13}$ (2004, p. 1053)

\footnotetext{
12 Meu pai, de volta a casa, está sentado a um sofá junto de minha mãe, que imprime com uma tinta indelével as iniciais na roupa branca espalhada sobre a mesa, ao lado da qual se senta. Eu estou embaixo da mesa, a brincar com bolinhas de gude. Aproximo-me cada vez mais de minha mãe. Provavelmente a querer que ela participe de minhas brincadeiras. Num dado ponto, para erguer-me dali [entre eles] agarro as pontas da toalha que pendem da mesa e acontece o desastre. O tinteiro cai na minha cabeça, derrama-se pelo meu rosto e roupas, pela saia de mamãe e vai respingar levemente também as calças de papai. Este ergue uma perna para acertar-me um pontapé... (2006, p. 394-395).

13 [...] mas eu ainda me achava na cama com uma chávena à mão, da qual havia bebido todo o café com leite e na qual continuava a mexer com uma colherinha raspando o açúcar. Em certo ponto, a colherinha já não conseguia trazer mais nada e eu tentava alcançar o fundo da chávena com a língua e não conseguia. Acabei por ficar com a chávena numa das mãos e a colherinha na outra, olhando para meu irmão, que estava deitado na cama ao lado da minha e vagarosamente ainda sorvia o seu café, o nariz enfiado na xícara. [...] Seu rosto estava pálido e um pouco enfeado por um leve prognatismo. Disse-me:

- Me empresta a sua colher?

Percebi então que Catina se esquecera de lhe trazer a colher. Súbito e sem qualquer hesitação, respondi:
} 
O próximo na série da competição sexual é Giovanni Malfenti, do qual o protagonista busca arrebatar uma das filhas pelo casamento. Examinaremos no próximo capítulo como ele decide pelo casamento antes mesmo de conhecer as filhas de Giovanni; por ora, verifiquemos como tal competição esclarece a reação que a inicial comum provoca em Zeno: "le sue quattro figliuole avevano tutti i nomi dall'iniziale in a [...]. Quell'iniziale mi colpì molto più di quanto meritasse. Sognai di quelle quattro fanciulle legate tanto bene insieme dal loro nome. Pareva fossero da consegnarsi in fascio"14 (2004, p. 692-693). A principal menção às letras iniciais no romance ocorre no sonho da tinta derrubada, no qual elas simbolizam a ligação conjugal dos pais de Zeno. Assim, o seu interesse desmesurado pela inicial das filhas de Giovanni é um indício da repetição da competição sexual expressa nesse sonho. Em seguida, Zeno imagina comercializá-las em conjunto, uma associação livre de ideias que reforça que, longe de ter ideias amorosas ou eróticas, que deveriam ter alguma prioridade ao pensar na escolha de uma esposa, ele está voltado a pensar em Giovanni, um homem dedicado ao comércio.

A senhora Malfenti também participa da série da competição sexual - e pelo mesmo motivo que o marido - depois de se tornar uma rival edipiana por uma causa que mencionaremos ainda no presente estudo do componente paterno do recalque de Zeno. Como a repetição ocorre em relação a Augusta, a única filha que o protagonista descarta por não se sentir atraído por ela, ela também indica que qualquer uma das filhas serviria para atingir a senhora Malfenti ou o seu marido: "Essa poi abbracciò Augusta e la grandezza del suo affetto si rivelò in un singhiozzo che le sfuggì [...]. Io non potevo soffrire la signora Malfenti, ma devo dire che quel singhiozzo colorì, almeno per tutta quella sera, di una luce simpatica e importante il mio fidanzamento"15 (2004, p. 765).

Obviamente a série da competição sexual também inclui Guido, para quem o protagonista perde Ada e de quem não consegue nem mesmo arrebatar a amante, Carmen. Podemos supor que se trata de repetição edipiana porque as reações do protagonista não são nada razoáveis, dado que nenhuma das duas mulheres nunca

- Empresto, mas só se você me der em troca um pouco de açúcar.

Levantei a colher ao alto para aumentar o seu valor. (2006, p. 393-394).

${ }^{14}[\ldots]$ as quatro filhas tinham nomes com a inicial " $\mathrm{A}$ " [...]. Essa inicial impressionou-me bem mais do que seria admissível. Sonhava com aquelas jovens atadas umas às outras pelo nome, como mercadoria a ser vendida por atacado (2006, p. 74).

${ }^{15}$ Em seguida, abraçou a filha e a dimensão de seu afeto revelou-se no soluço que se lhe escapou [...]. Eu não conseguia suportar a sra. Malfenti; devo porém dizer que esse soluço, pelo menos por toda essa noite, coloriu de uma luz simpática e imponente o meu noivado (2006, p. 138). 
demonstrou nenhum interesse erótico por ele. Uma vez que a competição é assumida na própria diegese (embora apenas em parte do tempo), nos limitaremos a acrescentar uma associação feita implicitamente por Zeno que se fundamenta na repetição da competição sexual com o irmão, tal como este aparece no já citado sonho da colher: ele está sonolento, na cama e tomando uma xícara de café. Como já notou a estudiosa Beatrice Stasi: "questa immagine del fratello ricorda quella di Guido, subito dopo la prima simulazione di suicidio, descritta nel capitolo precedente" (2009, p. 135). Citemos o trecho aludido do romance:

Ero sul punto di interrompergli la sonnolenza cui s'era subito abbandonato, dichiarandogli che se voleva delle registrazioni se le facesse da sé.

Intanto fu portata una grande tazza di caffè nero che Ada gli porse. Egli trasse le braccia di sotto le coperte e con ambe le mani si portò la tazza alla bocca. Ora, col naso nella tazza, pareva proprio un bambino. ${ }^{16}(2004$, p. 984)

Não só aparecem as características do irmão no sonho, mas também o próprio Zeno compara Guido a um menino e justifica a comparação com algo que é descrito com as mesmas palavras nos dois casos: "col naso nella tazza". Não por acaso, essas palavras justamente expressam a competição sexual, dados os significados simbólicos do nariz e da xícara, que já mencionamos ao comentar o sonho da colher.

A série da competição sexual também inclui o doutor Muli, com quem o protagonista imagina disputar Augusta (2004, p. 640-652); o amigo Copler, com quem imagina competir por Carla e para quem finge ter uma vida sexual patologicamente intensa sem nem mesmo saber a razão pela qual o engana, conforme é relatado no sexto capítulo; o professor de canto Vittorio Lali, para quem perde a amante, o que é relatado no mesmo capítulo.

A série da competição sexual prossegue nas "continuações". O primeiro caso e o mais importante - é o de Valentino, genro de Zeno, e é, portanto, inverso ao de Giovanni, dado que, para Zeno, se passou da disputa da filha dos outros para a da sua filha Antonia. Tal rivalidade com o genro está presente nas três "continuações" nas quais ele aparece diretamente ou por meio do luto da esposa. Encontramos a primeira alternativa quando Zeno demonstra a sua oposição à ligação conjugal nos textos $U n$ contratto - desde a crença de que Valentino estaria piorando a raça do sogro devido aos

\footnotetext{
${ }^{16} \mathrm{Eu}$ estava a ponto de interromper-lhe a sonolência, à qual de súbito se abandonara, dizendo-lhe para fazer ele mesmo os lançamentos que quisesse.

Nesse ínterim, trouxeram-lhe uma grande chávena de café puro, que Ada lhe deu. Ele tirou os braços de baixo das cobertas e com ambas as mãos levou a xícara à boca. Ali, agora, com o nariz metido na chávena, parecia mesmo uma criança (2006, p. 332).
} 
atributos corporais (2004, p. 1108) até falando contra ele para a própria filha (2004, p. 1107) - e Le confessioni del vegliardo, que se limita ao corpo pouco atraente do genro (2004, p. 1150-1151).

O mais extraordinário é que a disputa continue mesmo após a morte do genro pelo fato de a filha entrar num luto incomum e sem nenhum sinal de que venha a terminar algum dia. Nesse contexto, Zeno passa a competir por Antonia tentando distraí-la da sua dedicação hiperbólica ao luto. Momentos-chave dessa configuração da competição sexual estão nos textos Le confessioni del vegliardo, no qual está o episódio da desonra do envelhecimento precoce (2004, p. 1153-1154), doença da qual morre Valentino, e Umbertino, quando Zeno reclama do filho de Guido, Carlo, para a filha. Usemos o segundo caso para uma breve análise. A reclamação é suspeita em si mesma, pois o protagonista quase sempre fala bem de Carlo, mas Antonia não se dá tão bem com ele. Assim, é provável que Zeno não seja sincero e só reclame dele para agradar a filha. Eis o trecho ao qual nos referimos:

\footnotetext{
Avevamo un po' chiacchierato e, causa il paragone con le altre sere, oso dire allegramente, per quanto quell'alegria fosse stata impiegata a lagnarmi con qualche amarezza di mio nipote Carlo, il figlio di Guido, che mi pareva, quella sera, pieno di difetti, poco affettuoso e poco serio. Antonietta m'aveva appoggiato e ciò contribuiva a rendere la mia loquela più facile ed abbondante. Era un conforto grande quello di sentirmi appoggiato dalla mia figliuola. Sono tanto solo sempre! Mi pareva di procedere appoggiato al suo braccio, o il suo lieve peso sostenuto dal mio.

[...] volli ringraziare Antonietta di avermi procurata una bella ora. Bacciandola in fronte mormorai: - Grazie, figliuola mia. Abbiamo passato insieme una bella serata.

La sua faccina subito si oscurò. Restò un momento silenziosa eppoi disse lentamente come se avesse studiato se stessa: - Sì, la stessa serata come se Valentino non fosse morto -. Rimase ancora per un instante esitante. Poi scoppiò in singhiozzi e corse via verso la sua stanza. [...] Ero oltrecché indignato anche molto offeso. Dio mio! È difficile a settant'anni non risentirsi di una mancanza di rispetto.

E durò lungo tempo la mia ira. Io m'ero coricato ma non trovavo il sonno. Tardi trovai qualche cosa d'altro: Il sospetto di aver sbagliato io. Perché avevo sentito il bisogno di constatare ch'essa s'era lasciata svagare dalle mie chiacchiere sul carattere di Carlo? Essa provava un rimorso quando abbandonava anche solo per qualche ora il suo dolore e il pensiero al defunto ed io lo sapevo, e avevo sentito io il bisogno di farla subito avvisata che deviava così? [...]

Ma quando essa [Augusta] mi raccontò che Antonietta le aveva racontato che sentendomi vantare la gioia di quella serata, le era parso che addirittura le fosse pervenuto un rimprovero dalla boca stessa di Valentino, io ricaddi sul guanciale vinto. Lottai! Io avevo solo voluto dire che quell'ora era stata tanto gradevole che subito m'ero sentito meglio disposto al sonno. Non si trattava mica di una gioia che potesse oltraggiare il lutto. (2004, p. 1181-1183)
}

A opinião sobre Carlo é bem outra no trecho a seguir, mas novamente ele serve para que Zeno se oponha ao luto da filha, até mesmo sugerindo que o faz de um modo 
ofensivo:

Ogni domenica egli era a cena da noi. Per me era quella la cena migliore della settimana. Egli [...] non sentiva il malumore di nessuno finché non era proprio gridato e perciò era capace di ridere molto anche se seduto accanto al lutto di Antonietta. Non lo offendeva perché assolutamente non lo vedeva. Ed io lo seguivo finché potevo. Certo non c'era nessun momento in cui io sapessi dimenticare il lutto di Antonietta [...]. (2004, p. 1187)

Para encerrarmos a exposição dedicada ao luto de Antonia por Valentino, assinalemos que Zeno até mesmo conjectura que a reação dela à morte do pai será totalmente diferente: "Antonia non avrebbe pianto affatto" (2004, p. 1146).

A série da competição sexual também está presente no texto Umbertino por meio da rivalidade com Carlo, para quem Zeno mente para superar a atividade sexual que é relatada pelo sobrinho (2004, p. 1186-1187), e com Fortunato, o motorista da família Cosini, a quem é sistematicamente hostil devido ao mal disfarçado desejo que sente por Renata, empregada da família que se torna amante de Fortunato (2004, p. 1192-1196). Essa competição também surge no texto Il mio ozio, no qual Zeno descobre que compartilha a prostituta Felicita com Misceli, um conhecido do protagonista: é assumida na própria diegese e recorre a comparações baseadas na velhice e nos cigarros que cada um fuma (2004, p. 1208-1210).

O final do parágrafo anterior já menciona a segunda característica do componente paterno do recalque edipiano, específica do caso de Zeno: o vício de fumar. O romance tem um breve relato do início da série dos cigarros, no qual aparecem um jovem da idade do protagonista na época e o irmão: "Pare che Giuseppe ricevesse molto denaro dal padre suo e ci regalasse di quelle sigarette. Ma sono certo che ne offriva di più a mio fratello che a me. Donde la necessità in cui mi trovai di procurarmene da me delle altre"17 (2004, p. 628). A série já inicia associada aos principais rivais edipianos dessa época: o irmão, dado que este recebia mais cigarros (essa é, pelo menos, a convicção de Zeno), e, ainda que mais implicitamente, o pai, pois parece que Giuseppe distribuía os cigarros porque recebia muito dinheiro do seu pai. Zeno reage conjuntamente aos rivais, uma vez que consegue mais dinheiro do pai justamente para comprar uma caixa de cigarros, o que provavelmente lhe permitiria superar a quantidade recebida pelo irmão: “Così avvenne che rubai. D’estate mio padre abbandonava su una

\footnotetext{
${ }^{17}$ Parece que Giuseppe ganhava muito dinheiro do pai e nos presenteava com aqueles cigarros. Tenho certeza, porém, de que os oferecia mais a meu irmão do que a mim. Vem daí a necessidade que enfrentei para conseguir outros por conta própria (2006, p. 15-16).
} 
sedia nel tinello il suo panciotto nel cui taschino si trovavano sempre degli spiccioli: mi procuravo i dieci soldi occorrenti per acquistare la preziosa scatoletta"18 (2004, p. 628629).

Em seguida, a competição pelo vício passa a ser diretamente com o pai: "Mio padre lasciava per la casa dei sigari virginia fumati a mezzo, in bilico su tavoli e armadi. Io credevo fosse il suo modo di gettarli via e credevo anche di sapere che la nostra vecchia fantesca, Catina, li buttasse via. Andavo a fumarli di nascosto"19 (2004, p. 629). Assim, filho e pai disputam o mesmo objeto de desejo e satisfazem-no também com esse objeto compartilhado. O ápice dessa disputa ocorre no trecho do sorriso da mãe, que já citamos: após terminar de fumar o charuto que o pai procura, o sorriso da mãe expressa para Zeno a cumplicidade dela com a realização do seu desejo e com a privação do desejo do rival, o que remete muito eficazmente à configuração original do complexo de Édipo.

Da série dos cigarros deriva a dos últimos cigarros, na qual é quase totalmente absorvida e que analisaremos ainda neste capítulo. Entre as poucas ocorrências da série original após o surgimento dos últimos cigarros, mencionemos o episódio com Felicita e Misceli no texto Il mio ozio por retomar a ligação com o dinheiro, presente no início da série, e destacar a associação com a competição sexual devido a Zeno usar a compra de cigarros como pretexto ao surpreender Misceli na casa de Felicita, e a eles também recorrerem a esse uso para se referirem às visitas a ela (2004, p. 1208-1211). Além disso, a ligação com o dinheiro é reforçada quando o irmão dela entrega os cigarros usados como pretexto para ser pago por eles (2004, p. 1215-1217).

A terceira característica do componente paterno do recalque edipiano de Zeno apareceu bastante ao tratarmos do vício de fumar: é a competição monetária. Apesar dessa forte conexão com a série dos cigarros, essa característica se desenvolve numa série autônoma. Inclusive a conversa com Misceli também traz essa característica desvinculada dos cigarros: "avrei voluto sapere quanto egli pagasse mensilmente a Felicita. Mi pareva che se avessi saputo che - come a me pareva giusto - egli avesse pagato più di me, io mi sarei dichiarato contento" (2004, p. 1212).

\footnotetext{
${ }^{18}$ Sucedeu, portanto, que passei a roubar. No verão, meu pai deixava sobre uma cadeira, na sala de jantar, seu colete, em cujo bolso havia sempre alguns trocados: eu catava as moedas necessárias para adquirir a preciosa caixinha (2006, p. 16).

${ }^{19}$ Meu pai deixava pela casa charutos virgínia fumados a meio, equilibrados à borda das mesas e das cômodas. Eu imaginava que era a sua maneira de jogá-los fora e pensava também que nossa velha criada Catina dali os poria no lixo. Comecei a fumá-los às escondidas (2006, p. 16).
} 
A primeira ocorrência do dinheiro na sua série autônoma se deve ao apelido que Zeno dá ao pai: “All’Università tutti lo conoscevano col nomignolo ch'io gli diedi di vecchio Silva manda denari" ${ }^{20}$ (2004, p. 654). Outras ocorrências da série no romance são proporcionadas pela reação avarenta ao participar da filantropia de Copler (2004, p. 807) e pelo fato de escolher Lali para professor de canto da amante por ser o mais barato da cidade (2004, p. 880$)$.

No texto Un contratto, há uma fase de negociação do novo contrato proposto pelo filho de Olivi, e o que Zeno ainda tenta fazer, já considerando que não está em condições de se desfazer do administrador, é evitar de ganhar menos do que ele. Isso é obliquamente assinalado quando, após fazer duas propostas nas quais os ganhos das duas partes são iguais, comenta que lhe parece haver feito uma única proposta: "Proposi che a me fosse assegnato un onorario uguale al suo e si dividesse poi il beneficio oppure che si trascurasse di fissare un onorario qualunque sia a me che a lui e si procedesse alla divisione dell'utile. A me pareva di aver fatta una proposta sola ma non all'Olivi" (2004, p. 1099).

Por fim, a série do dinheiro ressurge até mesmo na tentativa de se reconciliar com o filho no texto Le confessioni del vegliardo, quando Zeno se sente enganado após receber a pintura que comprou dele (2004, p. 1131).

Além da competição sexual, outra característica óbvia e genérica do componente paterno do recalque edipiano é o desejo de morte dedicado aos rivais. É claro que a série dessa característica começa com o pai, a quem Zeno deseja a morte quando ele está gravemente enfermo (2004, p. 675). No caso de Guido, o protagonista se propõe a ser o próprio agente que concretizaria tal desejo ao jogá-lo rumo a uma queda letal (2004, p. 775). A série prossegue com Copler, cuja morte Zeno primeiro deixa transparecer que deseja por meio de uma hipótese e depois é incapaz de lamentar: "La sua respirazione rumorosa era composta da due suoni: [...] precipitoso quello che nasceva dall'aria espulsa. Fretta di morire?"21 (2004, p. 853) e "Ma la mia lacrima

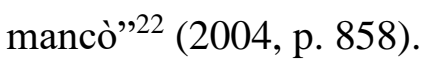

O desejo de morte contra os rivais também pode levar Zeno a imaginar-se como a causa do seu falecimento, ainda que não tenha pensado isso antes deles

\footnotetext{
${ }^{20} \mathrm{Na}$ universidade todos o conheciam pelo apelido que eu lhe dava: $O$ Velho Silva Mão-Aberta (2006, p. 40).

${ }^{21}$ A respiração ruidosa compunha-se de dois sons: [...] precipitado o que brotava do ar expulso. Pressa de morrer (2006, p. 216)?

${ }^{22}$ Mas a minha lágrima falhou (2006, p. 220).
} 
morrerem. É o que acontece no texto Un contratto ao ser informado da morte do velho Olivi (2004, p. 1090) após lhe enviar a carta na qual conta o sucesso que teve durante o período no qual assumiu os negócios; em vez disso, o rival foi vitimado por uma reles gripe.

O desejo de morte dedicado a Valentino ganha expressão jocosamente póstuma quando, no texto Umbertino, Zeno dá como exemplo do motivo que alega para amar o neto Umbertino a experiência imaginária que o menino inventa para entender o que significa que alguém esteja morto (2004, p. 1158-1159). Afinal, a ideia de chutar o falecido pai talvez seja compatível com uma suposta inocência infantil, mas ela deve ter ressonâncias bem diferentes em Zeno, dado que Valentino é um dos seus rivais edipianos. Há um trecho semelhante no mesmo texto, mas no qual não há necessidade de um intermediário para que Zeno expresse a satisfação pela morte do genro, já que ele mesmo imagina uma situação cômica com o rival no mundo dos mortos que lhe permite sorrir apesar da hora imprópria para isso (2004, p. 1169).

A série do desejo de morte atinge um ápice no texto Le confessioni del vegliardo com a tentativa ostensiva de Zeno de matar o amigo Cima. O protagonista resolve caçar sob a orientação do amigo, mas contraria a recomendação de não dar sinal de vida ao acender um cigarro. Isso provoca uma violenta reação por parte de Cima, que, de uma posição afastada, atira no companheiro e passa a lhe insultar, e então é a vez de Zeno, que não sabe atirar, acertar o chapéu do amigo (2004, p. 1141).

A quinta característica do componente paterno do recalque edipiano de Zeno é a aparência dos cabelos. A forma mais abrangente dessa característica é a competição capilar, que é claramente exposta quando a empregada lamenta a morte do pai do protagonista: “- Morire così! Con questa ricca e bella chioma. - L'accarezzava. Era vero. La testa di mio padre era incoronata da una ricca, bianca chioma ricciuta, mentre io a trent'anni avevo già i capelli molto radi"23 (2004, p. 667). Essa competição reaparece com os rivais Guido (2004, p. 735) e Cima (2004, p. 1142).

Há duas outras formas pelas quais a aparência dos cabelos é apropriada pela rivalidade edipiana de Zeno, mas elas se restringem à relação com Ada. A primeira delas opera com a sexta característica do componente paterno do recalque edipiano de Zeno, a do riso e da oposição à seriedade, que é explicitamente declarada como um dos

\footnotetext{
23 - Morrer assim, com estes cabelos tão lindos! - Acariciava-o. Era verdade. A cabeça de meu pai era cingida por uma bela cabeleira branca encaracolada, enquanto que eu aos trinta anos já tinha cabelos bastante ralos (2006, p. 52).
} 
aspectos da relação entre o protagonista e o seu pai: "Egli [o pai] mi rimproverava due altre cose: la mia distrazione e la mia tendenza a ridere delle cose più serie. [...] In quanto al mio disprezzo per le cose serie, io credo ch'egli avesse il difetto di considerare come serie troppe cose di questo mondo" 24 (2004, p. 657). Esse aspecto da relação com o pai é retomado num dos dois trechos do texto Prefazione que o menciona; mais precisamente, ficamos sabendo que o protagonista riu muito de um dos livrinhos nos quais o pai anotava lembretes para si mesmo (2004, p. 1230).

A oposição entre o riso e a seriedade é igualmente determinante para a relação de Zeno com o filho, que também o reprova por rir de tudo (2004, p. 1125-1126). Logo, não é por acaso que as duas desavenças sérias de Zeno com Alfio aconteçam por aquele rir deste. A primeira delas é provocada pela avaliação irônica que faz da teoria do filho sobre a arte e a personalidade por meio da exaltação da personalidade de Giacomo, que se embebeda com vinho e dorme durante o serviço (2004, p. 1126-1127). A segunda desavença séria acontece quando zomba das pinturas do filho, um evento que abordaremos ainda no presente capítulo.

Por fim, a seriedade de Ada é destacada por Zeno, o qual se dedica a rir de coisas consideradas sérias num contexto burguês; de fato, tanto a seriedade dela quanto o riso que o protagonista lhe opõe aparecem diversas vezes no trecho dedicado à visita à família Malfenti na qual conhece Ada, dentre as quais apresentamos três exemplos:

\footnotetext{
Ada, invece, era già una donna con i suoi occhi serii in una faccia che per essere meglio nivea era un poco azzurra e la sua capigliatura ricca, ricciuta, ma accomodata con grazia e severità. ${ }^{25}(2004$, p. 697)

Partii così alla conquista di Ada e continuai sempre nello sforzo di farla ridere di me e alle spalle mie dimenticando ch'io l'avevo prescelta per la sua serietà. Io sono un po' bizzarro, ma a lei dovetti apparire veramente squilibrato. ${ }^{26}(2004$, p. 699$)$

Io, invece, elessi la fanciulla dalla voce tanto grave e dalla capigliatura un po' ribelle, ma assettata severamente e pensai che, tanto seria, non avrebbe rifiutato un uomo intelligente, non brutto, ricco e di buona famiglia come ero io. ${ }^{27}(2004$, p. 704$)$
}

\footnotetext{
${ }^{24}$ Reprovava-me duas outras coisas: a minha distração e a minha tendência de rir das coisas mais sérias. [...] Quanto ao meu desprezo pelas coisas sérias, creio que meu pai tinha o defeito de considerar como tais demasiadas coisas desse mundo (2006, p. 42).

${ }^{25}$ Ada, ao contrário, já era mulher, com seus olhos sérios numa face que chegava a ser azulada de tão nívea, emoldurada por uma espessa cabeleira, encaracolada, embora disposta com graça e rigor (2006, p. 78).

${ }^{26}$ Parti assim na conquista de Ada e continuei sempre no propósito de fazê-la rir-se de mim ou à minha custa, sem lembrar que a havia escolhido por sua seriedade. Não deixo de ser um tanto estranho, mas devo ter-lhe parecido perfeitamente desequilibrado (2006, p. 79).

${ }^{27}$ Em vez disso, escolhi a moça de voz um tanto grave e cabeleira um pouco rebelde severamente presa e pensei que, sendo séria, não recusaria um homem inteligente, nada feio, rico e de boa família como eu (2006, p. 84-85).
} 
Retomando as apropriações edipianas da aparência dos cabelos, a segunda forma pela qual elas ocorrem é a agregação dos cabelos como um dos elementos que compõem a seriedade de Ada para Zeno, como ocorre no primeiro e no último exemplos citados supra. A última forma pela qual há tal apropriação edipiana é a equiparação do sentimento de perda definitiva que teve com a morte do pai - trataremos disso ainda neste capítulo - a partir do momento que presencia sinais de que Ada ama Guido. $\mathrm{O}$ significante que conecta os dois momentos são os caracóis notados tanto no pai morto quanto na nuca de Ada que lhe volta as costas para ficar com outro durante a noite da mesa espírita (2004, p. 751-753), configuração que ressurge até mesmo no sonho com ela (2004, p. 961).

A sétima característica do componente paterno do recalque edipiano de Zeno é a tradução da rivalidade em termos espaciais ou respiratórios. Além de uma ocorrência baseada no quarto de Carla, da qual trataremos neste capítulo quando analisarmos as complexas repetições que constituem a relação com a amante, há mais duas traduções espaciais na diegese do terceiro romance, ambas centradas na ocupação de um sofá; eis a primeira delas:

Le quattro fanciulle [as quatro irmãs Malfenti] erano sedute sul piccolo sofà sul quale stavano a stento ad onta che Anna sedesse sulle ginocchia di Augusta. Erano belle così insieme. Lo constatai con un'intima soddisfazione vedendo ch'ero avviato magnificamente all'ammirazione e all'amore. ${ }^{28}$ (2004, p. 699)

A satisfação constatada na citação equivale ao interesse desmesurado de Zeno pela inicial das filhas de Giovanni, que já abordamos ao estudar a competição sexual: assim como a inicial comum, a concentração espacial proporcionada pelo pequeno sofá expressa a identidade das irmãs para o desejo do protagonista de arrebatar ao rival uma das suas filhas.

Eis a segunda das ocorrências em análise: "Nel pomeriggio trovai Guido in ufficio. Era sdraiato sul nostro sofà in un curioso stato intermedio fra la disperazione e il sonno"29 (2004, p. 1011). O valor simbólico do sofá (lembremos também o importante episódio com a mãe nesse móvel, que analisaremos no próximo capítulo) nesse caso é plenamente adequado, dado que é o primeiro encontro com Guido após Zeno saber que

\footnotetext{
${ }^{28}$ As quatro moças [as quatro irmãs Malfenti] estavam sentadas no pequeno sofá, um tanto comprimidas para que Anna pudesse sentar-se nos joelhos de Augusta. Eram belas assim juntas. Constatei-o com íntima satisfação, vendo que me sentia magnificamente propenso à admiração e ao amor (2006, p. 80).

${ }^{29}$ De tarde, encontrei Guido no escritório. Estava estendido no sofá, num curioso estado intermédio entre o desespero e o sono (2006, p. 356).
} 
o rival perdeu muito dinheiro na bolsa de valores e, portanto, é um momento muito apropriado para que o desejo de derrotá-lo para conquistar Ada seja projetado sobre a configuração espacial na qual Guido está estirado sobre um sofá.

O caso contrário - o reconhecimento de sofrer uma derrota, real ou imaginária - pode ser acompanhado pela repetição do sintoma da dificuldade para respirar. No romance, isso ocorre em situações nas quais o protagonista sente que a mulher desejada o rejeita, como neste exemplo com Ada: "A me mancò il fiato. Era evidente che Ada mi evitava" $^{\prime 30}$ (2004, p. 709). Também lhe falta o fôlego em situação equivalente com Carla: "Quel suo saluto secco significava addirittura l'abbandono e fu quella la prima volta in cui seriamente lo temetti. La dura minaccia mi toglieva il fiato"31 (2004, p. 888).

A falta de fôlego aparece associada a uma derrota diferente no texto $U n$ contratto, no qual Zeno reconhece que precisará aceitar o novo contrato proposto pelo filho de Olivi: "E mi mancava il fiato sentendo la importanza del momento. In quel momento vedendolo [o filho de Olivi] tanto sicuramente disinvolto in un affare simile e sentendo me infelice e malsicuro intuii la superiorità sua e decisi di conservarlo nei miei affari a tutti i costi” (2004, p. 1099). No texto Il mio ozio, há o caso da rejeição sexual por parte de Felicita no que será o último encontro com ela: “Invece così m'indignai. Non trovai parole; quasi non trovai l'aria per respirare. Dissi: - Uff - con la massima indignazione" (2004, p. 1219). Também há o caso do texto Umbertino no qual uma invenção do neto é associada à morte de Zeno por asfixia e provoca o único sonho do protagonista nas "continuações":

\begin{abstract}
[Umbertino construiu uma casa de brinquedo com caixinhas], la casa del nonno che vi potrebbe capire se gli si tagliasse via una parte del corpo, anzi tutto il corpo meno la testa. [...] Antonia obiettò: - Vuoi davvero il nonno morto? Con la testa non potrebbe respirare. [...]

La grande fantasia del piccolo uomo m'inquinò. Ebbi una notte dell'affanno e tale affanno ricreò in un sogno orrendo l'idea di Umbertino. M'avevano portato via tutto il corpo e non restava di me che la sola testa poggiata su una tavola. Parlavo anche, e sopportavo tutto come se volessi eseguire il volere di Umbertino. Ma la respirazione era necessariamente breve e mi lasciava l'affannosa sete dell'aria ed io pensavo: "Quanto tempo dovrò respirare così fin che il corpo mi ricresca?". (2004, p. 1159-1160)
\end{abstract}

Finalmente, há um trecho no texto Umbertino no qual a competição sexual por Antonia encontra expressão espacial na consideração da posse e da divisão da casa da

\footnotetext{
${ }^{30}$ Quase perdi o fôlego. Era evidente que Ada me evitava (2006, p. 89).

${ }^{31}$ Sua seca despedida significava a bem dizer o abandono e foi a primeira vez em que seriamente o temi.

A dura ameaça me tirava o fôlego (2006, p. 246).
} 
viúva: "Veramente quella vasta casa pareva vuota. [...] E il Bigioni guardava serenamente intorno a sé. Quanto spazio v'era là per lui, anche troppo. Si sentiva tanto sicuro che forse meditava di subaffittare una parte di quel quartiere non appena fosse stato suo" (2004, p. 1169-1170).

A oitava característica do componente paterno do recalque edipiano de Zeno é a competição segundo uma atividade, uma habilidade ou uma qualidade pela qual, por um lado, o rival consiga uma vitória, se destaque (notoriamente ou apenas conforme a própria opinião) ou poderia se destacar (dada a sua função social ou o tempo que lhe dedica), e, por outro lado, o protagonista não é especialmente reconhecido; pelo contrário, geralmente Zeno está em franca desvantagem na disputa. A mais longeva competição desse tipo está baseada no comércio, atividade para a qual o protagonista nunca se preparou, seja pelos estudos, seja pelo exercício direto de tal prática. A sua origem está no testamento do pai do protagonista, o qual estabelece que Olivi deve permanecer como administrador dos negócios da família e, portanto, impede que Zeno os assuma na sua condição de único herdeiro (2004, p. 658).

Logo após a morte do pai, surgem as iniciativas de Zeno para se preparar para assumir os negócios e desbancar o rival Olivi, o que justamente se torna o principal elemento da relação entre os dois. O protagonista começa a frequentar a bolsa de valores como um exórdio à atividade comercial, se vincula a Giovanni por considerá-lo uma verdadeira cátedra comercial e, após algum tempo, lhe declara que quer descartar Olivi e assumir a direção dos negócios, mas Giovanni fica alarmado e o dissuade dessa intenção, o que sugere que a incompetência comercial de Zeno é notória (2004, p. 686687).

Uma vez bloqueada a sua investida para assumir os negócios, Zeno é impelido a empregar meios de permanecer vinculado a eles, como a iniciativa de simplesmente trabalhar na empresa (a qual ele apresenta inicialmente como um presente para Augusta, a esposa que ele não ama) e - quando essa iniciativa também fracassa - as muitas horas que passa na bolsa de valores. A iniciativa fracassa porque o protagonista não se restringe ao propósito inicial: tenta interferir nas decisões comerciais após começar a ter sentimentos de um jogador num cassino que o fazem ter a esperança de ter um entendimento melhor do que os demais para identificar a oportunidade de um bom negócio. Além de Zeno ser novamente preterido pelo sogro em favor de Olivi, a esposa deixa de apoiá-lo para ficar do lado dos rivais edipianos e, portanto, também se tornar um deles (2004, p. 796-800). 
O romance possui mais dois episódios nos quais Zeno age com o objetivo de assumir os negócios que eram do pai: o do doutor Muli, o qual abordaremos ainda no presente capítulo, e o da última data do diário, do qual trataremos no quarto capítulo.

O texto Un contratto continua a apresentar a repetição em análise, mas de modo simétrico, pois o protagonista passou a dirigir a empresa do pai durante a guerra e tenta evitar a assinatura do novo contrato proposto pelo filho de Olivi, que claramente é o assunto central desse texto, pois a principal consequência dessa assinatura é justamente a perda da direção da empresa. Adiantamos esse comentário no presente capítulo devido à importância desses acontecimentos para a repetição edipiana que estamos analisando, mas faremos a sua devida análise no quinto capítulo deste trabalho. No seu final, o texto Un contratto ainda traz outra novidade ao apresentar uma situação na qual o prejudicado imediato não é o próprio protagonista, mas o filho, que

\begin{abstract}
[...] pensò di dedicarsi al commercio e mettersi in società con l'Olivi. Ma si trovò che nel contratto c'era una clausola che glielo proibiva. - In fondo brontolò Alfio che non brilla per essere molto riguardoso - questa era una eredità del nonno e non bisognava lasciarla toccare.

Io allora passai qualche giorno a studiare quali concessioni avrei potuto offrire all'Olivi per ottenere il permesso per Alfio di collaborare nel suo ufficio. Pensavo di comperare tale permesso con un'ingente somma di denaro. [...] mi sentivo suo debitore ciò che mi rese anche più riguardoso nelle mie già difficili relazioni con lui. (2004, p. 1115)
\end{abstract}

Para encerrarmos a análise dessa repetição de destacada longevidade, pontuemos que o texto Prefazione, cujas histórias são muito posteriores à morte do pai, ainda traz um evento referente ao testamento feito por ele; mais precisamente, é uma recomendação do pai sobre a direção dos negócios que Zeno encontra: "Assolutamente (e questa parola è sottolineata) non devo dimenticare di dire all'Olivi quando se ne presenti l'occasione che mio figlio alla mia morte dovrà apparire verso tutti quale il vero padrone benché tale non sarà mai” $(2004$, p. 1231).

Apesar da sua extrema importância, a disputa pela direção dos negócios paternos não esgota os casos de conflito comercial contra os rivais edipianos. Ele ainda é um dos elementos importantes das relações com Giovanni, como podemos verificar no episódio das ações de uma fábrica de açúcar (2004, p. 689-690), no qual Zeno ganha dinheiro com tais ações ao não seguir o conselho do sogro, que vendera as suas, e com Guido, como podemos constatar no jogo de Zeno na bolsa de valores para recuperar as perdas do concunhado, o qual é concebido como uma competição entre eles e ainda serve como uma espécie de compensação pelo célebre lapso do funeral (2004, p. 1037 1038). 
Uma vez que examinamos a principal das competições em análise, a comercial, exponhamos as demais disputas nas quais Zeno se empenha em participar, apesar de estar potencial ou efetivamente em desvantagem. Elas são dedicadas a um único personagem e geralmente são um dos principais elementos da história da sua relação com o protagonista. Comecemos pela senhora Malfenti, que se torna uma rival edipiana quando diz a Zeno que compromete Augusta e o orienta a se afastar, ainda que temporariamente, da casa da família Malfenti e, portanto, de Ada. A futura sogra é extremamente versada nas convenções da cortesia, inclusive ao comunicar a mensagem desagradável dessa conversa, de modo que a reação de Zeno à nova rival durante os dias de afastamento é justamente tentar vencê-la na comunicação de recados corteses, mas que respondam com desprezo ao afastamento que ela cortesmente lhe propôs: ele começa enviando flores para ela com um bilhete contendo apenas a data (2004, p. 721); considera que foi derrotado quando ela responde com um bilhete com as simples letras iniciais de um agradecimento (2004, p. 725); e lhe escreve uma carta na qual informa que fará uma longa viagem, mas nunca se propôs efetivamente a enviá-la (2004, p. 728).

No caso de Guido, Zeno toma a iniciativa de enfrentá-lo em três episódios nos quais tenta reverter uma vitória que o rival alcança por meio de uma habilidade artística: o episódio da disputa de caricaturas (2004, p. 766-768), no qual o próprio Zeno reconhece o resultado infantil e insatisfatório dos seus desenhos; o da exibição de Guido ao violino (2004, p. 755-757), no qual o protagonista, que é um péssimo violinista, tenta fazer um reparo despropositado sobre um pequeno trecho da execução após o rival tocar o instrumento com extraordinária competência; e o da disputa de fábulas (2004, p. 947951), no qual a reação apaixonada de Carmen às duas fábulas de Guido, seu amante, faz o protagonista ser atormentado pelas dores surgidas durante o sucesso das caricaturas do concunhado em ridicularizá-lo e a tentar provar que também é capaz de criar fábulas apesar de nunca sermos informados de que tenha qualquer dom especial para tal atividade.

O próximo personagem que consideraremos é Copler, cujo critério que coloca Zeno em desvantagem é a própria enfermidade. De fato, o rival tem uma doença grave, nefrite, e, ao saber por Augusta que o marido - que estava muito interessado pelos seus remédios - tem uma doença imaginária, se inicia uma competição de desprezo mútuo entre os enfermos, o imaginário e o real (2004, p. 801-803). Zeno encontra uma possibilidade de vencer o embate ao sugerir que o doente real só sente a dor quando a morte não pode mais ser evitada, de modo que também se trata de uma repetição do 
desejo de morte do rival, e ele não deixará de aproveitar a concretização dessa possibilidade quando Copler se tornar um moribundo (2004, p. 855) e finalmente sucumbir a uma paralisia renal (2004, p. 858).

Os últimos personagens do romance que abordaremos na presente etapa da nossa análise são os médicos, cuja capacidade para observar o paciente ou avaliar a gravidade do estágio da doença é colocada em dúvida pelo protagonista, apesar de ele não ter nenhuma formação ou atuação profissional na área de saúde. Ele questiona sistematicamente a primeira capacidade no caso do médico com o qual faz um tratamento com eletricidade (2004, p. 635-637) e as duas capacidades no caso do doutor Paoli, quando este trata a doença de Giovanni (2004, p. 852).

As "continuações" apresentam outra competição com o pai, justamente pelo mais competente na própria função paterna; eis como é introduzida: "Pensai che sarei stato attento di non cadere nei difetti di mio padre e che avrei saputo trattare altrimenti mio figlio. Ma Dio mio! Guai se a mio padre fosse toccato un figlio simile" (2004, p. 1121). Quando Zeno estiver fazendo as pazes com o filho, a vitória sobre o pai é mencionada: "E pensai anche che mio padre non avrebbe saputo fare altrettanto" (2004, p. 1131).

Há também as competições a respeito de pintura com Alfio e de caçada com Cima - atividades que estão entre as principais desses personagens -, as quais abordaremos dentro de um contexto mais amplo ainda neste capítulo.

Encerremos a investigação das características fornecidas para os componentes do recalque de Zeno tratando da nona característica da rivalidade edipiana. Ela é própria das "continuações" - mais precisamente, do texto Umbertino - e consiste em estabelecer a rotina da convivência com o rival segundo o compulsório efeito de restrição da liberdade. É o caso do neto que, morando na casa do avô, insiste em lhe contar histórias:

\footnotetext{
Le storie le raccontava lui. Ne sapeva - credo - due soltanto che io non saprei ridire perché non stetti mai a sentirle. Quando ne avevo sopportata una guardando i gesti interessanti del bambino in lotta con la parola, egli [...] mi domandava: - T'è piaciuta? Vuoi che te la racconti di nuovo? -. Io proponevo ch'egli la raccontasse di nuovo intanto ch'io avrei letto, scritto o suonato il violino.

No, dovevo starlo a sentire altrimenti egli non sentiva la realtà del racconto. Io mi provavo di star a sentire ma subito nel mio petto sorgeva il temporale solito: "Come sono buono, come sono buono" e per poter attendere ai fatti miei consegnavo il bambino a Renata. (2004, p. 1162)
}

A convivência com o neto também restringe a liberdade de Zeno devido aos 
passeios diários que fazem juntos:

Si camminava tanto bene insieme per tutte le vie della città, io molto meno distratto di lui perché richiamato alla realtà da una minaccia d'automobile o dall'ammirazione per quel bambino dalla testa ingombra da schiocchezze. [...] non ero libero essendo incatenato a una sorveglianza. (2004, p. 1167)

Além disso, a restrição da liberdade também é um elemento crucial da convivência com Bigioni, que interrompe as leituras e as audições de Zeno (2004, p. 1176-1177).

\subsection{Os conflitos transitórios entre as repetições e o estabelecimento da sucessão diegética a despeito da recorrência}

Uma vez que identificamos as características fornecidas para o recalque edipiano de Zeno e, com base nelas, as séries das repetições mais simples que constituem a vida do protagonista, investiguemos os aspectos da temporalidade repetitiva da diegese que dependem desse resultado inicial do nosso estudo. O primeiro deles que abordaremos deriva de que as recorrências edipianas não operam isoladamente umas das outras; pelo contrário, elas incessantemente interagem entre si. Já mencionamos ocorrências de repetições que operam de modo a haver uma relação de reforço entre elas, como o vício de fumar e as competições sexual e monetária que praticamente determinam a função de Misceli na história de Zeno, e outros casos surgirão no presente capítulo. Não nos deteremos sobre essa interação porque ela produz apenas consequências triviais para a nossa investigação. $\mathrm{O}$ que nos permite explorar um amplo conjunto de situações que ainda não abordamos é a interação inversa, o conflito entre repetições.

Como caso exemplar da interação conflituosa entre repetições, escolhemos um de abrangência tão extrema que quase se confunde com a própria abrangência da rivalidade edipiana; se trata de um conflito que se estabelece em Zeno entre os componentes materno e paterno do complexo de Édipo e cujo trecho que melhor o explicita é o da dúvida sobre ser mau. Após tratar Guido com grande rudeza ao conversar com ele sobre o desastre do primeiro balanço e a possibilidade de prisão caso a empresa não fosse fechada e viesse a falir, Zeno, que trabalha como contador da 
empresa, se torna incapaz de continuar a justificar a rudeza com o concunhado quando chegam ao lugar no qual cogitou seriamente em matá-lo, pois isso impede que a distorção da originalidade da vida seja suficiente para efetivamente enganar a si próprio sobre a continuidade da rivalidade entre o candidato a assassino de outrora e o atual contador implacável, de modo que surge a recordação da dúvida sobre ser mau que é exposta perante a mãe:

Io invece ricordai che in quel luogo l'avevo voluto uccidere, e confrontando i miei sentimenti di allora con quelli di adesso, ammiravo una volta di più l'incomparabile originalità della vita. Ma improvvisamente ricordai che poco prima e per una bizza di persona ambiziosa, avevo imperversato contro il povero Guido e ciò in una delle peggiori giornate della sua vita. Mi dedicai ad un'indagine: Assistevo senza grande dolore alla tortura che veniva inflitta a Guido dal bilancio messo insieme da me con tanta cura e me ne venne un dubbio curioso e subito dopo un curiosissimo ricordo. Il dubbio: ero io buono o cattivo? Il ricordo, provocato improvvisamente dal dubbio che non era nuovo: mi vedevo bambino e vestito (ne sono certo) tuttavia in gonne corte, quando alzavo la mia faccia per domandare a mia madre sorridente: "Sono buono o cattivo, io?". Allora il dubbio doveva essere stato ispirato al bimbo dai tanti che l'avevano detto buono e dai tanti altri che, scherzando, l'avevano qualificato cattivo. Non era affatto da meravigliarsi che il bimbo fosse stato imbarazzato da quel dilemma. Oh incomparabile originalità della vita! Era meraviglioso che il dubbio ch'essa aveva già inflitto al bimbo in forma tanto puerile, non fosse stato sciolto dall'adulto quando aveva già varcata la metà della sua vita.

Nella notte fosca, proprio su quel posto ove io una volta avevo già voluto uccidere, quel dubbio mi angosciò, profondamente. Certamente il bimbo quando aveva sentito vagare quel dubbio nella testa da poco libera dalla cuffia, non ne aveva sofferto tanto perché ai bambini si racconta che della cattiveria si guarisce. Per liberarmi da tanta angoscia volli credere di nuovo così, e vi riuscii [...]. Il proposito rinnovò l'illusione! Il proposito di mettermi accanto a Guido e di collaborare con lui allo sviluppo del suo commercio da cui dipendeva la sua e la vita dei suoi e ciò senz'alcun utile per me. Intravvidi la possibilità di correre, brigare e studiare per lui e ammisi la possibilità di divenire, per aiutarlo, un grande, un intraprendente, un geniale negoziante. ${ }^{32}$

\footnotetext{
32 De minha parte, recordei que tive vontade de assassiná-lo ali naquele lugar, e confrontando meus sentimentos de então com os de agora admirava mais uma vez a incomparável originalidade da vida. De súbito recordei que pouco antes e por capricho de pessoa ambiciosa me havia irritado com o pobre Guido, e isto num dos piores dias de sua vida. Concentrei-me numa indagação: assistia sem compaixão à tortura infligida a Guido pelo balanço que eu preparara com tamanho cuidado, e me veio uma dúvida curiosa, seguida de uma curiosíssima recordação. A dúvida: eu era bom ou mau? A recordação, provocada repentinamente pela dúvida que não era nova: via-me em criança e vestido (estou certo) ainda em calças curtas, erguendo o rosto para perguntar à minha mãe sorridente: "Eu sou bom ou sou mau?". Essa dúvida devia ter sido inspirada ao menino por todos que o achavam bom, e por tantos outros que, de brincadeira, o qualificavam de mau. Não era, portanto, de admirar que a criança se sentisse embaraçada por tal dilema. Oh! Incomparável originalidade da vida! Era extraordinário que a dúvida já infligida por ela à criança, de forma tão pueril, não fosse resolvida pelo adulto depois de transposta metade de sua existência.

$\mathrm{Na}$ noite escura, exatamente naquele lugar onde uma vez já quisera matar, aquela dúvida angustiou-me profundamente. Decerto a criança não sofrera tanto ao sentir a dúvida vagar por sua cabeça mal liberta da touca, pois em pequenos nos dizem que nos podemos emendar. Para libertar-me de tanta angústia, quis acreditar de novo nisto e consegui [...]. O propósito renovou a ilusão! O propósito de ficar ao lado de Guido e de colaborar com ele no desenvolvimento de seus negócios, dos quais dependia a suma [sic] vida e a dos seus, e isto sem qualquer proveito para mim. Entrevi a possibilidade de correr, brigar e estudar por causa dele e admiti a possibilidade de me tornar, para ajudá-lo, um grande empreendedor, um genial negociante (2006, p. 323).
} 
(2004, p. 973-974)

A renovada angústia de que a mãe o julgaria mau faz com que Zeno abandone de vez o tratamento rude dedicado a Guido durante a conversa sobre o balanço em favor do propósito de ajudá-lo a recuperar a empresa do desastre! Logo, o trecho citado expõe como a repetição pela qual Zeno evita o julgamento de ser mau produz uma limitação na hostilidade manifestada nas repetições da rivalidade edipiana, o que resulta no modo velado pelo qual o protagonista se dedica ao exercício dessa rivalidade.

Não é o caso de explorarmos minuciosamente a rivalidade velada de Zeno, pois seria uma análise demasiado extensa por ser comum a praticamente todas as suas manifestações de hostilidade. Assim, restringiremos a nossa abordagem a três situações nas quais uma compensação é produzida justamente pelo protagonista haver ultrapassado o limite da hostilidade velada de algum modo.

O primeiro caso do qual trataremos será daqueles trechos nos quais Zeno recua após o seu comportamento hostil ser reconhecido, explícita ou implicitamente, por outrem. No romance, isso é bem característico das relações que estabelece com Giovanni e Guido. Quanto ao primeiro, mencionaremos três trechos. O primeiro é o episódio das ações de uma fábrica de açúcar (2004, p. 689-691), no qual o desejo de vencer Giovanni ganhando dinheiro com as ações que o sogro recomendara que vendesse, como ele mesmo já fizera, até causa um esquecimento recorrente e uma mentira para Giovanni, mas, após o sogro se mostrar ofendido, o protagonista descarta a vitória lhe contando a verdade.

Aproveitemos o contraste no modo como o protagonista concebe o recuo da hostilidade nos dois trechos que já comentamos para apresentar brevemente um importante aspecto temporal da falta de reconhecimento da repetição. No trecho da dúvida sobre ser mau acontece algo excepcional: uma associação livre na forma de uma recordação manifesta elementos do passado que estão ligados ao confronto presente. Muito diferente disso, o que costuma ocorrer é que Zeno simplesmente aborda o conflito em termos de elementos do presente, como é o caso do apaziguamento com o sogro no episódio que mencionamos no parágrafo anterior: "Mi spiacque d'irritarlo. Era tanto più divertente quand'egli danneggiava me. Gli raccontai sinceramente com'erano andate le cose"33 (2004, p. 691). Sem considerar a atuação no presente de elementos do

\footnotetext{
${ }^{33}$ Não me agradava irritá-lo. Era muito mais divertido quando me passava para trás. Por isso contei sinceramente como as coisas se tinham passado (2006, p. 72).
} 
passado, Zeno tenta justificar o que faz apenas por meio de relações entre os participantes imediatos da ação, e a falta de efetividade das relações referidas para prover a explicação almejada é assinalada pelo tratamento irônico dado à justificativa.

Retomemos os casos de recuo na hostilidade contra Giovanni. Em outro trecho, o protagonista até mesmo projeta a sua hostilidade velada nas considerações com o sogro sobre como se conduzir na competição comercial (e, ao mesmo tempo, tenta superá-lo na sua própria atividade profissional mais uma vez): ao invés da fama de astúcia defendida por Giovanni, Zeno propõe que o comerciante realmente astuto deve parecer um tolo (2004, p. 687). Encerremos os casos envolvendo o sogro mencionando o trecho no qual Zeno, embriagado, serve vinho no copo de água de Giovanni e, portanto, toma a iniciativa de agir no sentido de matá-lo, já que ele está impedido de beber por estar muito doente. O sogro reage ao gesto do parente com uma acusação de assassinato, a qual, por sua vez, faz o protagonista se sentir vil apesar de ser obviamente exagerada, dado que se tratava apenas de uma provocação feita diante de outras pessoas (2004, p. 860-861).

No tocante a Guido, apresentaremos três exemplos que se destacam pela demarcação clara da passagem da hostilidade para o apaziguamento. No primeiro deles, Zeno e o rival caminham juntos na mesma noite do episódio da exibição de Guido ao violino. O protagonista retoma o reparo feito nesse episódio, e dessa vez o violinista reconhece que cedeu a um capricho, o que basta para que Zeno valorize os dotes musicais do rival por meio de duas declarações, apaziguando a situação como se fossem bons amigos, ainda que há pouco haja perdido a mulher desejada para ele (2004, p. 772773). O segundo exemplo ocorre no episódio da disputa de fábulas (2004, p. 947-951), no qual o protagonista consegue uma vitória quando Guido reconhece que a primeira história de Zeno era um modo de atacá-lo, mas recua após a interpretação que dá ao olhar indagador de Carmen de que ele não amava o concunhado. Para que seja esclarecido que não teve intenção maligna, declara - duas vezes! - que o rival criava fábulas melhores.

O terceiro exemplo de recuo de Zeno numa hostilidade a Guido ocorre após as enormes perdas de Guido na bolsa de valores; mais precisamente, o protagonista trata rudemente, em tom exaltado de voz, o concunhado até que este finalmente reconhece o próprio erro e, a partir desse momento, Zeno cessa de hostilizá-lo, é tomado de compaixão por ele - a ponto de cogitar abraçá-lo - e se arrepende da rudeza com a qual o tratou (2004, p. 1015-1016). 
O recuo do comportamento hostil de Zeno também aparece nas "continuações". No texto Un contratto, acompanhamos uma discussão que dura dias sobre as situações distintas do protagonista e da família Olivi durante a guerra. Ela acaba com uma resposta na qual Zeno alça a voz para o filho de Olivi e que é seguida, frente à incapacidade de reação do rival, por um brusco recuo: se aborrece por falar alto e avalia favoravelmente o argumento do adversário (2004, p. 1094). Por fim, o texto Le confessioni del vegliardo apresenta um caso extremo desse recuo ao operar numa hostilidade feita a uma mosca:

[...] una volta, di sera, prima de coricarmi, arrivai a dare un lieve colpo ad una mosca che mi tormentava. La bestiola, ferita, arrivò a sfuggirmi, ed io invano la cercai volendo finirla per compassione. Non la trovai e durante la notte più volte pensai al povero animaluccio che doveva agonizzare in qualche canto recondito della stanza pieno di dolore e di rancore. (2004, p. 1139)

O segundo caso de compensações provocadas por violações do limite da hostilidade velada é específico das "continuações" e abarca uma situação duplamente frustrante: Zeno está diante de uma derrota para o rival e não é capaz de ter uma reação hostil que seja adequada à derrota imposta nem consegue manter a hostilidade plenamente velada, expondo o aborrecimento que lhe provoca o convívio com o rival ou um representante seu. À dupla frustração Zeno reage pensando sobre a própria "bondade" por não ser agressivo como desejava, o que tanto compensa o reconhecimento mínimo da hostilidade pelo rival quanto serve como um protesto pelo desejo insatisfeito. No texto Un contratto, isso ocorre duas vezes com o genro, que está representando o filho de Olivi na negociação do novo contrato, o qual significa uma derrota ímpar na crucial questão da condução dos negócios herdados do pai; logo, tratar do contrato com Valentino significaria ser também derrotado por ele. Para exemplificar, citemos o término da primeira dessas interferências do genro, no qual encontramos o seu reconhecimento do aborrecimento do protagonista e o chute que permaneceu apenas como um desejo que Zeno não realizou:

[...] prima da andarsene [Valentino] domandò scusa di avermi seccato. Io allora mi feci affettuoso ricordandomi che se c'era qualcuno da rimproverare era l'Olivi e non Valentino e gli sorrisi, lo ringrazia[i], l'accompagnai fino alla porta. Così egli non poté affatto accorgersi che dal mio animo sorgeva una rampogna ch'io spesso sento: "Come son buono! Come son buono!". [...] Che il povero morto mi perdoni ma in quel momento anzicché sorridergli come feci avrei voluto accelerare la sua uscita con un calcio. (2004, p. 1097)

O pensamento sobre a própria bondade também aparece nos textos Le confessioni del vegliardo e Umbertino. No primeiro, Zeno tenta se reaproximar de Alfio 
após ambos se ofenderem no almoço com Cima. Como o filho nunca se desculpou pelas ofensas, o desejo de Zeno seria revidá-las novamente, o que sabota o seu esforço de tomar a iniciativa de se reaproximar do Alfio, pois assume um aspecto estranho e pouco afetuoso enquanto pensa sobre o quanto é bom (2004, p. 1145). No segundo texto, Umbertino conta histórias para o avô que não o escuta, pois se ocupa em ler, escrever ou tocar violino. Quando o neto exige que ele escute, Zeno tenta fazê-lo, mas subitamente reage à interferência no seu lazer pensando sobre o quanto é bom e se nega a fazer o gosto do neto deixando-o com a empregada (2004, p. 1162).

O terceiro caso de compensações provocadas por violações do limite da hostilidade velada é destinado a compensar especificamente a concretização do desejo de morte de um rival edipiano por meio do sentimento de culpa. Para não nos delongarmos desnecessariamente, desprezaremos as manifestações diretas de tal culpa no enredo, cuja principal ocorrência está no capítulo do romance que é dedicado à morte do pai, e nos limitaremos a mencionar exemplos nos quais a culpa em análise se apoia numa construção imaginária. A principal dessas construções é a projeção de uma suposta reprovação dirigida a Zeno, geralmente envolvendo o próprio corpo, moribundo ou já morto, do rival: os últimos movimentos do pai moribundo são compreendidos como uma bofetada dada no filho, ainda que não haja nenhum elemento para corroborar se essa era a intenção paterna (2004, p. 682-683); Zeno pensa que o rosto do cadáver de Copler "manifesta" uma desaprovação desdenhosa por ele, o doente imaginário que sobrevive ao doente real (2004, p. 858); e, quando Guido morre, o protagonista encontra uma reprovação numa fotografia da mãe do falecido, que aparenta um ar muito severo (2004, p. 1041).

Em acréscimo aos exemplos já dados, recorramos de modo pontual ao oitavo capítulo para demonstrar que as mortes podem ser apenas supostas para que Zeno projete a reprovação sobre os cadáveres dos rivais; é o que podemos observar na próxima citação, na qual ele se dedica a imaginar a morte do cabo do pelotão e do pai de Teresina, os quais ele havia iludido dizendo que não haveria combates na região, e a reação de surpresa de ambos - como se reconhecessem que caíram numa emboscada armada pelo rival que fingia ser um amigo:

Volli renderlo [o cabo] più felice che fosse possibile e gli diedi le notizie che avevo propinate anche al padre di Teresina. Poi mi pesarono sulla coscienza. Nell'orrendo temporale che scoppiò, probabilmente tutte le persone ch'io rassicurai perirono. Chissà quale sorpresa ci sarà stata sulla loro faccia 
cristallizzata dalla morte. ${ }^{34}(2004$, p. 1078)

Além da projeção de uma suposta reprovação, destaquemos a construção imaginária que ocorre no texto Un contratto. Quando percebe que se submeterá ao novo contrato imposto pelo filho de Olivi, Zeno suspeita estar acometido por uma doença, a qual será a causa da morte do genro: "Non avevo allora che 63 anni ma poteva trattarsi di un invecchiamento precoce. [...] era la prima volta che in casa si evocava quella malattia. E quando essa colse Valentino ebbi per un momento un rimorso come se gliel'avessi appioppata io" (2004, p. 1101).

Uma vez que apresentamos a rivalidade velada de Zeno, cuja abrangência é de tal ordem que contempla a relação do protagonista com vários personagens do romance e das "continuações", complementemos o estudo da interação conflituosa entre repetições tratando também da sua importância em desenvolvimentos pontuais da história. Para isso, exporemos como o maior episódio do terceiro capítulo do romance, o do doutor Muli, e a principal sequência de acontecimentos do texto Le confessioni del vegliardo, a da tentativa fracassada de Zeno de fazer as pazes com Alfio, estão baseados nos conflitos entre recorrências. Antes de começarmos essa exposição, esclareçamos apenas que ela envolverá duas repetições que ainda analisaremos no presente capítulo: as tentativas fracassadas de parar de fumar e os cuidados com a saúde.

O episódio do doutor Muli (2004, p. 640-652) é uma das várias repetições de uma situação básica, derivada da série de repetições do vício de fumar: Zeno tenta parar de fumar, mas fracassa. Como a tentativa nesse episódio é justificada pela pouca disposição à atividade que lhe causa a nicotina, também estamos tratando de uma das várias repetições de outra situação básica: Zeno inicia um procedimento para cuidar de algum problema de saúde, mas o abandona sem que o objetivo dele seja atingido. Em conformidade com ambas as recorrências, o protagonista se interna na clínica do doutor Muli para se livrar do tabagismo, mas foge da internação e, logo após a fuga, busca novos cigarros. Devido a ambas, Muli se torna mais um rival edipiano do protagonista.

Às duas repetições que mencionamos se agregam outras que reforçam uma das tendências de ambas e, portanto, conflitam com a tendência oposta de cada uma delas. Por um lado, há as repetições do desejo de morte do rival e das tentativas de assumir os

\footnotetext{
${ }^{34}$ Quis torná-lo [o cabo] tão feliz quanto possível e transmiti-lhe as notícias que propiciara ao pai de Teresina. Depois, isso pesou-me na cosciência. No horrendo temporal que desabou, provavelmente todas aquelas pessoas que eu tranquilizara pereceram. Quem sabe a surpresa que terá ficado cristalizada em seus rostos pela morte (2006, p. 415).
} 
negócios herdados do pai. De fato, uma das justificativas dadas por Zeno para decidir pela internação é a consideração de que estaria pouco apto para substituir Olivi, que estava doente e ameaçava abandonar a administração da empresa, caso não se livrasse do seu vício. Logo, essa consideração permite a Zeno que as iniciativas associadas de parar de fumar e cuidar da saúde operem em reforço mútuo com os desejos de assumir os próprios negócios e de que o rival morra, que também estão associados porque a satisfação do segundo desejo acarreta que o primeiro seja igualmente satisfeito.

Por outro lado, surge a repetição de afastamento forçado que conflita com o bloco de repetições do parágrafo anterior. Destaquemos como trecho privilegiado para assinalarmos essa recorrência aquele no qual o próprio Zeno faz uma associação que fica desvinculada do enredo a partir de um comentário do médico, que apresentara argumentos quanto à impossibilidade de fugir da internação: “- [...] Non c'è male nevvero per una casa di salute destinata a bambini e puerpere? E si mise a ridere, forse all'idea di avermi rinchiuso fra bambini" 35 (2004, p. 642). O fato de ficar confinado faz Zeno se sentir uma criança. Assim, o confinamento recria a situação psíquica da separação física entre Zeno e o rival e a mulher disputada, experimentada quando ia para a escola enquanto o irmão ficava em casa com a mãe, de modo que o médico, que já era um rival edipiano devido aos cigarros e à terapia, está em condições de substituir a figura do irmão, e Augusta se torna a mulher da qual o protagonista é separado. Essa configuração excepcional causa um sentimento inédito em relação à esposa, envolvendo também o seu sorriso e os seus pés, elementos que estão ligados à mãe:

\begin{abstract}
Mia moglie si congedò da me insieme al dottore. Mi disse sorridendo:
- Giacché hai deciso così, sii forte.

Il suo sorriso che io amavo tanto mi parve una derisione e fu proprio in quell'istante che nel mio animo germinò un sentimento nuovo [...]. Una folle, amara gelosia per il giovine dottore. Lui bello, lui libero! Lo dicevano la Venere fra' Medici. Perché mia moglie non l'avrebbe amato? Seguendola, quando se ne erano andati, egli le aveva guardato i piedi elegantemente calzati. Era la prima volta che mi sentivo geloso dacché m'ero sposato. [...] Lottai! Il sorriso di mia moglie era il suo solito sorriso e non una derisione per avermi eliminato dalla casa. [...] Eppoi non ricordavo che non era tanto facile d'innamorarsi di mia moglie? Se il dottore le aveva guardato i piedi, certamente l'aveva fatto per vedere quali stivali dovesse comperare per la sua amante. ${ }^{36}$ (2004, p. 644)
\end{abstract}

\footnotetext{
35 - [...] O que não é mau para uma casa de saúde destinada a recém-nascidos e parturientes. E pôs-se a rir, talvez ante a ideia de me haver trancado junto com as crianças (2006, p. 28).

${ }^{36}$ Minha mulher despediu-se de mim juntamente com o doutor. Disse-me sorrindo:

- Já que você assim resolveu, aguente firme.

Seu sorriso, que eu amava tanto, pareceu-me zombeteiro e foi exatamente nesse instante que germinou em meu espírito um sentimento novo [...]. Um estúpido e amargo ciúme pelo jovem doutor. Ele era bonito, livre! Por que minha mulher não haveria de gostar dele? Seguindo-a, ao saírem, ele havia observado seus pés elegantemente calçados. Desde que me casara, era a primeira vez que sentia ciúmes. [...] Lutei! O
} 
Antes Zeno nunca tivera um sentimento trivial de ciúmes pela esposa nem se interessara pelos seus pés, apesar da capacidade que essa parte da anatomia feminina tem de lhe despertar o desejo sexual. Logo, a repetição do afastamento forçado cria as condições para que também se repitam a competição sexual, o sorriso como privação do desejo do marido (no caso, o de fumar) para favorecer o de outro (no caso, um adultério) e o fetichismo. Todas essas repetições estabelecem um reforço mútuo entre si e com o fracasso da tentativa de parar de fumar e a interrupção da internação na clínica.

Com base nas considerações anteriores, concluímos que o episódio do doutor Muli trabalha com diversas repetições, que podemos agrupar em dois blocos de modo que as recorrências de cada grupo se reforçam mutuamente e entram em conflito com as do outro bloco. O episódio se desenvolve em torno das relações de reforço e conflito das repetições que elencamos até que finalmente a situação se resolve com a fuga da internação e, portanto, em favor do grupo da retomada do vício tabagista.

Encontramos uma situação equivalente na tentativa fracassada de Zeno de fazer as pazes com Alfio (2004, p. 1128-1145). A principal diferença é que o conflito crucial se torna mais transparente, ainda que continue a não ser efetivamente reconhecido na diegese, devido à história da repetição edipiana de um período anterior - a rivalidade com Cima - ser colocada dentro da narrativa da história com Alfio.

Verifiquemos como se estabelece o conflito entre as repetições no caso da tentativa de reconciliação com Alfio. Zeno só se empenha em fazer as pazes porque teme a reação do filho à sua morte, o que é uma repetição, ainda que de modo simétrico, do desejo de morte do rival, e, como não pode evitar a própria morte, tenta terminar a rivalidade com Alfio para que ele não deseje a morte do pai. Essa recorrência inicial é reforçada pela competição de Zeno com o pai pela competência no desempenho da própria função paterna, dado que o pai não foi capaz de atingir a reconciliação com o protagonista.

O início da tentativa de reconciliação com Alfio é perturbado pelo conflito com a repetição da competição monetária, primeiro em relação ao preço a ser estipulado ao quadro que Zeno se propõe a comprar do filho e depois quando se sente enganado por um hábil comerciante ao receber a pintura e detestá-la. Essa competição é superada

sorriso de minha mulher era o seu sorriso de sempre e não um escárnio por me haver afastado de casa. [...] Além de tudo, não era nada fácil para alguém enamorar-se de minha mulher. Se o doutor lhe havia reparado os sapatos, era certamente porque queria comprar uns iguais para a sua amante (2006, p. 29-30). 
quando o protagonista passa a admirar o quadro de Alfio ao se sentir um colaborador ativo da pintura, mas a reconciliação só dura até Zeno conversar com o filho, pois este rejeita a colaboração daquele que observa a pintura, a qual ele considera um produto do olhar analítico do pintor. Ainda que consideremos que Alfio não seja simpático ao recusar acolhimento a outra opinião convincente sobre a própria obra, é inegável que Zeno não tem nenhuma formação ou experiência prática em pintura e, mesmo assim, não consegue admitir a opinião do próprio autor do quadro, à qual se restringe a reproduzir mecanicamente para não desagradá-lo. Além disso, se recusa a apreciar outro quadro com o qual o filho o presenteia. Esse modo de reagir à rejeição da sua apreciação da pintura de Alfio configura mais uma repetição da competição numa atividade de grande valor para o rival e é crucial para o desenlace do conflito com as repetições que sustentam a relação apaziguada com o filho.

É nesse momento do relato que é interpolada a história de outra relação edipiana cuja emergência de uma repetição a ela relacionada contribui decisivamente para o conflito em análise. Trata-se da rivalidade com Cima na juventude, que culmina com o episódio da caçada, ele próprio baseado num conflito de repetições. O episódio inicia com mais uma competição numa atividade estimada pelo rival, a caça, que Cima costuma praticar: Zeno quer se equiparar a Cima aprendendo a caçar, mas a hostilidade velada lhe cria dificuldades até quando golpeia uma mosca. Durante a espera por um animal para alvejar, surge uma nova tentativa de fumar o último cigarro, o que conflita com o propósito de caçar, pois afugenta possíveis presas no ambiente escuro. Devido ao cigarro aceso, Cima atira em Zeno, o que faz este revidar com um tiro no chapéu do rival, o que é mais uma repetição do desejo de morte do protagonista.

Voltando à história da relação apaziguada com Alfio, é a repetição da rivalidade com Cima que transforma uma troca de zombarias entre Zeno e o seu amigo que provoca risadas nos participantes de um almoço que reúne a família do protagonista numa competição na qual ele é incapaz de aceitar ser o último a ser zombado a ponto de usar os quadros de Alfio como objeto de troça. Assim, a tentativa de fazer as pazes com o filho é decidida num embate final de repetições edipianas de Zeno, no qual o desejo de morte e a disputa com o pai baseada na própria função paterna são sobrepujados pelas competições de zombaria com Cima e de julgamento pictórico com Alfio, a quem volta a opor a sua opinião sobre o quadro comprado e revela que evita olhar a pintura que ganhou dele, e pela oposição entre o riso e a seriedade, cuja gravidade é enorme devido ao motivo da troça ser aquilo que há de mais sério para o filho. De passagem, o 
protagonista ainda encontra oportunidade para aliar mais uma repetição, a dos cuidados com a própria saúde, às hostilidades contra o filho quando atrela o exame da pintura que ganhou à condição de estar com plena saúde, o que espera alcançar com o tônico que toma há cerca de um mês.

Uma vez que introduzimos o conflito entre as repetições na presente seção, estamos em condições de compreender as principais razões pelas quais a presença massiva de recorrências devidas à compulsão à repetição não faz com que uma sensação de estagnação impeça que vigore uma concepção da diegese como sucessão de acontecimentos durante a leitura. Isso é pouco intuitivo e se deve às repetições de Zeno geralmente não serem reconhecidas como tais por ele mesmo, que, portanto, concebe a própria história como sucessão; serem múltiplas e se alternarem entre si, tornando mais difícil identificar aquelas cuja distribuição é mais descontínua; e, por fim, estabelecerem relações conflituosas entre si, de modo que uma determinada ação do protagonista pode ser efetivamente contrária a qualquer uma delas, desde que seja a realização de uma das outras, e, portanto, qualquer dificuldade para reconhecer o conflito pode contribuir para que a ação não seja só contrária a uma recorrência, mas também opere como negação da sua existência.

\subsection{A instauração de ciclos no conflito: a repetição oscilatória}

A relação entre a sucessão e a repetição irrefletida de Zeno na diegese ganha mais um nível de articulação quando o conflito entre as recorrências parte de uma determinada situação e se desenvolve de modo a voltar a ela, o que constitui um ciclo. $\mathrm{O}$ ciclo é, em si, uma pequena sucessão com base em repetições e, ao mesmo tempo, é uma das ocorrências de uma repetição que acontece indefinidas vezes e que se encadeiam como sucessão na medida em que o seu aspecto recorrente não é reconhecido ou o é apenas parcialmente.

Introduzamos o tipo de dinâmica conflituosa que analisaremos na presente seção com a seguinte citação de Freud, que trata de um ato sintomático ou causal, um dos fenômenos da psicopatologia da vida cotidiana: 
ternamente, sem dúvida podiam reclamar para si alguns fundamentos reais, mas, como ele mesmo admitia, não eram assim inteiramente explicadas. Ele se ocupava incessantemente com a ideia do divórcio, que então voltava a descartar por amar muito ternamente seus dois filhos pequenos. Apesar disso, voltava constantemente a sua intenção e não buscava nenhum meio de fazer com que sua situação se tornasse suportável. Tal incapacidade de pôr termo a um conflito é vista por mim como prova de que motivos recalcados e inconscientes contribuíram para fortalecer os motivos conscientes que lutam entre si. (1987b, p. 168)

Logo a seguir, Freud relata como elucidou esse caso, no qual o paciente havia associado inconscientemente o divórcio entre os pais com a morte de um filho, de modo que o desejo de divorciar-se da esposa se tornou equivalente a desejar a morte dos filhos. Trata-se de uma repetição na qual o sujeito, incapaz de resolver o seu conflito psíquico, oscila continuamente entre os seus dois extremos.

A repetição oscilatória aparece pela primeira vez no romance quando Zeno fica doente e o médico lhe prescreve a abstenção de fumar, uma proibição que o pai reforça explicitamente mais de uma vez (2004, p. 631-632). Segundo a nossa perspectiva de construção do protagonista conforme a compulsão à repetição, ser proibido de fumar por alguém acarreta as seguintes consequências: o autor da proibição torna-se um rival edipiano (caso ainda não seja); Zeno, incapaz de se rebelar contra uma ordem direta que tem a sua saúde como objetivo porque isso seria uma violação da hostilidade velada que caracteriza a sua rivalidade edipiana, se dispõe a parar de fumar; e, sendo o tabagismo uma das suas repetições edipianas, volta a esse vício após algum tempo. Como o objetivo da saúde pode ser assumido pelo próprio Zeno, a existência de alguém que lhe imponha a proibição de fumar é descartável, ainda que ele a busque com frequência.

A repetição oscilatória da abstinência e do retorno ao tabagismo ganha dois modos de realização. O primeiro é dos últimos cigarros, aos quais o romance dedica um trecho do terceiro capítulo (2004, p. 632-635) além de apresentar algumas recorrências pontuais desse comportamento: tornando quase simultâneos os extremos da oscilação, Zeno fuma um cigarro como se nunca mais fosse fumar, fica sem fumar até recair no vício e decidir por um novo "último" cigarro. O segundo modo é constituído pelo envolvimento de outrem que forneça uma orientação para uma nova tentativa para parar de fumar: Zeno busca essa orientação alheia ou ela the é fornecida sem que precise buscá-la; caso ela seja obtida, ele começa a segui-la, mas posteriormente ele desiste dela e volta aos cigarros. As ocorrências principais desse modo são o tratamento médico com eletricidade (2004, p. 635-638), o conselho de um amigo para não pensar no vício (2004, p. 638-640), a aposta com Olivi (2004, p. 640) e a internação na clínica do 
doutor Muli, que já analisamos neste capítulo. As ocorrências mais importantes dessa repetição oscilatória nas "continuações" estão na história de Cima no texto Le confessioni del vegliardo, principalmente o episódio da caçada (2004, p. 1139-1142).

A proibição que origina as tentativas fracassadas de parar de fumar também gera outra repetição oscilatória, a dos cuidados com a saúde. Esta continua a ser um dos extremos do conflito, mas o outro se generaliza - em substituição ao vício de fumar para ser qualquer doença ou distúrbio corporal que se deseje curar, inclusive disposições corporais que estariam aquém do desejável: Zeno adota um cuidado terapêutico, o qual é abandonado ou nunca mais é mencionado; de qualquer modo, jamais somos informados de que a cura pretendida foi obtida. Assim, as duas repetições com médicos que mencionamos no parágrafo anterior também são recorrências de cuidados explicitamente interrompidos com a saúde. De fato, já observamos, ao analisar o episódio do doutor Muli, que um dos motivos para Zeno se decidir pela internação é a pouca disposição à atividade e, no caso do outro médico, o protagonista se submete ao tratamento com eletricidade na esperança de ser proibido de fumar, mas o médico despreza a sua reclamação sobre a nicotina, e a terapia se prolonga por setenta aplicações de eletricidade com Zeno se queixando de distúrbios bem diversificados.

Desvinculada do tabagismo, os cuidados com a saúde estão distribuídos ao longo do romance, aparecendo nos remédios acumulados e nos tratamentos buscados por Zeno para as dores surgidas com as caricaturas de Guido (2004, p. 768-770), no interesse pelos remédios de Copler (2004, p. 801) e até nas variadas rotinas terapêuticas mencionadas no diário, das quais as últimas a serem mencionadas são o sal de Carlsbad, o passeio antes do café e a ginástica respiratória de Niemeyer (2004, p. 1071-1072). Por fim, a ocorrência crucial dessa repetição oscilatória para o romance é a terapia com o doutor S., pois é a causa ficcional para a existência do texto, mas só faremos a análise de tal cuidado médico no quarto capítulo, no qual finalmente estaremos em condições de abordá-lo devidamente.

O texto Il mio ozio é constituído com base na repetição oscilatória dos cuidados com a saúde. A primeira parte do texto (2004, p. 1198-1201) é dedicada a uma sucessão variada de remédios e tratamentos voltados ao corpo com um todo ou a doenças ou órgãos específicos, mas apenas um dos problemas originais efetivamente apresenta alguma melhora, o da pressão sanguínea das artérias. A transição da primeira para a segunda parte do texto (2004, p. 1202) elege o órgão sexual, cuja função reprodutiva é prejudicada pela velhice, para ser o objeto de cuidado, e o tratamento escolhido é 
arranjar uma amante. A segunda parte é o episódio da relação com Felicita (2004, p. 1204-1219), a amante. O tratamento em si não entra na repetição oscilatória em análise, pois é bem sucedido, uma vez que Zeno retoma o nível da atividade sexual de um patamar anterior ao da sua idade atual; entretanto, o modo como se encaixa no texto é o dos cuidados com a saúde, já que o protagonista arranja a amante para comprovar a capacidade reprodutiva do seu órgão sexual e retorna à situação inicial quando termina a relação com Felicita. A terceira e última parte do texto (2004, p. 1220-1221) é o das relações fugidias com as mulheres na rua, que funcionam como comprovações demasiado efêmeras e hipotéticas da aptidão do seu órgão sexual para a reprodução.

As tentativas fracassadas de parar de fumar são a repetição oscilatória da qual Zeno mais explicita o aspecto recorrente, e as diversas retomadas dos cuidados com a saúde são algo esperadas devido à caracterização hipocondríaca do protagonista, mas as repetições oscilatórias que são concentradas num único personagem, as quais passaremos a analisar, quase não são reconhecidas por Zeno. Dentre os personagens que entram nesse caso, escolhemos Ada, Carla e Bigioni para abordarmos a seguir porque consideramos que são os que melhor representam a variedade de configurações que esse tipo de repetição pode assumir.

Comecemos pela repetição oscilatória que é estabelecida no início da relação com Ada e que Zeno não demonstra reconhecer. Ela consiste na hesitação do protagonista para pedi-la em casamento, ainda que frequente diariamente a casa da família Malfenti. Quanto à opção do matrimônio, uma das recorrências edipianas de Zeno é, como já comentamos, a competição sexual com Giovanni, pela qual decide se casar com uma das suas filhas antes mesmo de conhecê-las. No tocante à procastinação do pedido, o contato pessoal com Ada faz o protagonista reencontrar nela algumas características importantes dos seus rivais edipianos, a principal das quais é a seriedade. Zeno, inclusive, se opõe a ela pelo riso, e ela o faz associar o cabelo encaracolado do seu pai com o da mulher desejada, como também já expusemos. Se os aspectos de rivalidade se impõem quando o protagonista está junto de Ada, a repetição do desejo pela mãe se sobressai quando os dois estão separados, o que podemos verificar, por exemplo, no seguinte trecho:

Purtroppo io non vivevo solo con Ada le ore che passavo in quella casa. Essa ben prestò m'accompagnò il giorno intero. [...] L'adornai, le prestai tutte le tante qualità di cui sentivo il bisogno e che a me mancavano, perché essa doveva divenire oltre che la mia compagna anche la mia seconda madre che 
m'avrebbe addotto a una vita intera, virile, di lotta, e di vittoria. ${ }^{37}$ (2004, p. 705)

Assim, Ada é explicitamente assinalada como uma substituta materna e provoca em Zeno uma repetição do desejo pela mãe que nenhuma outra mulher é descrita como capaz de causar, o da característica da totalidade desse desejo. Concluímos que a relação inicial com Ada é constituída por uma repetição oscilatória segundo a qual Zeno, como resultado das repetições da competição sexual com Giovanni e do desejo pela mãe, pretende se declarar para Ada quando está longe dela e, ao visitá-la com uma frequência que logo se torna diária, se dedica a outra repetição contando histórias que se opõem à seriedade que a caracteriza em vez de lhe propor qualquer tipo de união. Essa situação, por si mesma de duração indeterminada, perdura da primeira visita à família Malfenti até a terceira ausência consecutiva da filha mais velha (2004, p. 694-709), a qual evidencia que Zeno é evitado pela mulher que deseja. Em reação a isso, ele finalmente age no sentido de declarar o seu desejo beijando a mão dela.

A partir da terceira ausência consecutiva de Ada, a relação de Zeno com ela entra numa etapa intermediária, na qual não se opõe mais à seriedade dela; pelo contrário, ele até mesmo ressalta que a deseja com esse atributo (2004, p. 722). Sem a repetição que impedia a ligação íntima com Ada, a repetição oscilatória se produz como um conflito direto entre as duas repetições restantes pela primazia nessa ligação, de modo que Zeno oscila entre torná-la sua esposa, sem que importe o amor dela, ou sua amada, mesmo que não se fale em casamento. Assim, o seu sentimento mais forte ao compreender que ela o evita não é de tristeza, e pensa em apelar ao pai dela para efetuar o casamento: "Curioso che quella prima volta il più forte sentimento che sentissi allo scontrarmi nella resistenza di Ada fosse di collera e sdegno! Pensai anche di appellarmi a Giovanni per mettere la fanciulla all'ordine. Un uomo che vuole sposarsi è anche capace di azioni simili"”38 (2004, p. 709-710). No dia seguinte, Zeno justamente se opõe a essa ordem de ideias e exige saber se ela o ama, inclusive por meio do seu corpo:

Un dubbio doloroso: e se Ada m'avesse sposato solo perché indottavi dai genitori, senz'amarmi ed anzi avendo una vera avversione per me? [...]

\footnotetext{
${ }^{37} \mathrm{E}$ dizer que com Ada eu não passava apenas as horas em que permanecia naquela casa. A moça não me saía da mente o dia inteiro. [...] Emprestei-lhe todas as qualidades de que sentia falta, para que, além de minha companheira, ela fosse também uma espécie de segunda mãe que me conduzisse por uma vida íntegra, viril, de lutas e conquistas (2006, p. 85-86).

${ }^{38}$ Curioso que o primeiro sentimento que me assaltou ao esbarrar na resistência de Ada fosse de cólera e desdém! Pensei até em recorrer a Malfenti para chamar a filha à ordem. Um homem a fim de casar-se é capaz de tais ações (2006, p. 89).
} 
Sull'orizzonte si delineava proprio il solito romanzo popolare della giovinetta costretta dalla famiglia ad un matrimonio odioso. Ma io non l'avrei permesso. Ecco la nuova ragione per cui dovevo parlare con Ada, anzi con la sola Ada. Non sarebbe bastato di dirigerle la frase fatta [que requisitaria a permissão para pedir a mão ao seu pai] che avevo preparata. Guardandola negli occhi le avrei domandato: “Mi ami tu?". E se essa m'avesse detto di sì, io l'avrei serrata fra le mie braccia per sentirne vibrare la sincerità ${ }^{39}(2004, \mathrm{p}$. 715)

A última menção a tratar com Giovanni sobre o casamento com Ada é a reação final de Zeno contra os dias de afastamento que lhe foram exigidos pela senhora Malfenti: "Via le esitazioni! Non importava più di sapere se ella mi amasse. Bisognava tentare di ottenerla e non occorreva più parlare con lei se Giovanni poteva disporne. Prontamente bisognava chiarire tutto per arrivare subito alla felicità o altrimenti dimenticare tutto e guarire" ${ }^{40}$ (2004, p. 722). No caminho para encontrar Giovanni, Zeno finalmente se torna consciente de que toda a família Malfenti pretende que ele se case com Augusta, de modo que não poderia recorrer a Giovanni para casar com Ada; pelo contrário, a primazia dada à competição sexual resulta na exigência de que renuncie à mulher desejada para tomar Augusta como esposa. A partir desse momento, acaba a repetição oscilatória em análise, e a relação com Ada passa a operar como um reforço entre as duas recorrências que estavam em conflito sob a restrição de que a competição sexual com o rival esteja subordinada à repetição do desejo pela mãe.

A repetição oscilatória que se desenvolve por meio da relação com Carla é ainda mais dinâmica do que aquela que terminamos de examinar. Antes de abordarmos tal dinamismo, explicitemos a base repetitiva da história com a amante. O próprio protagonista evoca o aspecto recorrente da ligação com Carla ao associá-la às tentativas de parar de fumar, diretamente (2004, p. 817) ou por meio de datas que deveriam marcar uma suposta última traição (2004, p. 838-840), tais como as datas dos últimos cigarros. Dentre os elementos do texto que permitem identificar a base da repetição oscilatória com Carla, elegemos o episódio no qual ela quer conhecer a esposa de Zeno e ele a faz encontrar Ada em vez de Augusta (2004, p. 889-892). Associando essa troca

\footnotetext{
${ }^{39}$ Uma dolorosa dúvida: e se Ada quisesse casar comigo só por instigação dos pais, sem amar-me e até sentindo certa aversão por mim? [...] No horizonte delineava-se o próprio enredo dos romances populares em que a "mocinha" era obrigada pela família a um casamento odioso. Só que eu não permitiria. Eis a nova razão porque devia falar com Ada, ou seja, com ela a sós. Não bastava que lhe dirigisse a frase feita [que requisitaria a permissão para pedir a mão ao seu pai] que trazia pronta comigo. Olhando-a nos olhos, perguntaria: "Você me ama?". Se dissesse sim, eu a estreitaria nos braços para sentir-lhe a vibração da sinceridade (2006, p. 94).

${ }^{40}$ Bastava de hesitações! Não importava saber se ela me amava ou não. O importante era obtê-la, e já nem pensava em falar com ela, porquanto Giovanni me poderia concedê-la. Forçoso era esclarecer tudo de uma vez, para chegar logo à felicidade, ou, em vez disso, esquecer tudo e curar-me (2006, p. 100).
} 
ao título do sexto capítulo, o qual se refere à esposa e à amante sem nomeá-las, propomos que, tanto no episódio quanto no título, não há dúvida sobre quem é a amante, mas a determinação de quem Zeno efetivamente considera como esposa não é tão simples, pois pode ser tanto Augusta quanto a mulher que ele realmente deseja, ou seja, Ada.

Em suma, Zeno deixa transparecer que faz certa confusão entre a esposa e a irmã que o rejeitou, e entendemos que isso se deve ao casamento com Augusta ser a única ligação que ainda possui com a irmã efetivamente desejada, de modo que a ruptura conjugal seria o rompimento com ambas. Se considerarmos essa conexão estreita dentro do contexto das relações conflitantes de Zeno com Ada e com Carla, o resultado é o seguinte: por um lado, o desejo por Ada é a causa de ele se esforçar para manter as aparências de um casamento perfeito, de se recuperar das traições com o afeto da esposa, de facilmente se tornar disposto a se afastar da amante e de planejar terminar com ela; por outro lado, o desejo por Carla é a causa para Zeno se permitir algumas indisposições com Augusta. Além disso, os dias que precedem o matrimônio de Ada e Guido fazem com que o protagonista se sinta traído e seja incentivado a revidar a "infidelidade" com Carla.

Estabelecida a base repetitiva do relacionamento com a amante, comprovemos a capacidade dinâmica que comporta a configuração temporal proporcionada pela repetição oscilatória. Para facilitar a nossa exposição, dividiremos em etapas o relacionamento em análise. A primeira etapa (2004, p. 807-869) se estende da primeira visita à casa de Carla até a manhã seguinte à morte de Copler (mas antes de Zeno rever a amante ainda nessa manhã) e é dominada pelos preparativos para o casamento de Ada e pela influência de Copler devido ao fato de ser o único que conhece tanto Carla quanto a família do protagonista. Assim, os modos pelos quais Zeno deseja a amante e se afasta dela são especialmente rudes, pois está sob o domínio dos ciúmes por Ada e do medo de que Copler descubra e revele as suas traições. A segunda etapa (2004, p. 869-875), que começa com a visita a Carla na manhã seguinte à morte de Copler e é interrompida pelo episódio do pernoite com a amante, se caracteriza justamente pelo término da rudeza na relação com ela devido a não ser mais confrontado com a mulher desejada prestes a ser casar com outro nem temer que as suas traições sejam reveladas, mas o protagonista ainda precisa se convencer de que consegue terminar com a amante, o que é concretizado com os propósitos de lhe arranjar um professor de canto que lhe proporcionasse uma carreira, permitindo que Zeno a abandonasse. 
A terceira etapa (2004, p. 875-880) é a do pernoite com Carla, que não é capaz de provocar mudanças permanentes na relação dos amantes porque a tentativa de pernoite não é bem sucedida. Esse fracasso acontece por causa do afastamento forçado da mulher desejada, tal como na internação na clínica do doutor Muli, mas, no caso em análise, Augusta é apenas a intermediária inevitável no desejo de Zeno por Ada. O impedimento ao qual Carla submete o amante, ao tentar mantê-lo a noite inteira no seu quarto, de experimentar o quanto antes o afeto da esposa e, portanto, de comprovar que a ligação com Ada persiste mesmo após mais uma traição origina novas repetições das traduções espacial e respiratória da rivalidade edipiana:

Ci coricammo infine nello stesso letto in una stanzuccia piccola e del tutto disadorna. Pareva un corridoio stroncato da una parete. Non avevo ancora sonno e mi disperavo al pensiero che, se ne avessi avuto, non avrei potuto dormire con tanta poca aria a mia disposizione.

[...] Quello che occorreva era di allontanarsi al più presto da quella piccola stanzuccia non contenente di più di un metro cubo di aria $[\ldots] .{ }^{41}(2004$, p. 876-877)

Todas as etapas seguintes estão relacionadas com Lali, o professor de canto escolhido por Zeno. A quarta etapa (2004, p. 880-883) começa com a contratação de Lali: Zeno se torna ciumento, mas passa a controlar esse sentimento para evitar o afastamento do professor, mantendo a possibilidade de que ele venha a lhe tomar a amante. A quinta etapa (2004, p. 883-886) começa com Lali pedindo Carla em casamento, e o resultado é equivalente ao da fase anterior: Zeno evita que a amante aceite o pedido, mas conserva o professor para manter a possibilidade de que ela venha a aceitá-lo.

A sexta etapa (2004, p. 890-895) começa quando, após Carla conhecer Ada, ela decide terminar com Zeno e aceita se casar com Lali. Antes da separação, ela concede ao amante uma última traição, a qual ele concebe como a primeira de uma repetição oscilatória de "últimas" traições, de modo análogo aos últimos cigarros. Ele também manifesta o seu desejo de que todos os dias se assemelhassem ao dessa última traição, do que depreendemos que esse é o padrão ideal de repetição para Zeno no que concerne à relação com Carla; é de tal padrão, portanto, que o protagonista tenta se aproximar, na medida do possível, em cada uma das etapas, o que torna mais fácil entender,

\footnotetext{
${ }^{41}$ Fomos deitar afinal na mesma cama do pequeno quarto desprovido de enfeites. Parecia um corredor bloqueado por uma parede. Eu ainda não tinha sono e me desesperava ao pensamento de que, mesmo que o tivesse, ser-me-ia impossível dormir com tão pouco ar à minha disposição.

[...] O que importava era fugir o mais rápido possível daquele minúsculo quarto onde não havia mais que um metro cúbico de ar [...] (2006, p. 236-237).
} 
respectivamente na segunda e quinta etapas, o seu propósito de arranjar um professor de canto e que ele mantenha Lali depois do pedido de casamento feito a Carla.

A sétima etapa (2004, p. 895-908) é a da iminente ruptura definitiva de Carla com Zeno e dos seus esforços desesperados para evitá-la, da qual trataremos na próxima seção deste capítulo. Por fim, a oitava etapa (2004, p. 908-909) é a da reação à ruptura definitiva, que consiste, como resultado da permanência do desejo por Carla, na substituição da amante por prostitutas mantendo o propósito de que cada traição seja a última, o que implica um certo afastamento do padrão idealizado por Zeno e resulta numa repetição oscilatória equivalente à dos últimos cigarros.

Assim, verificamos como uma mesma repetição oscilatória pode assumir diversas configurações conforme mudam as circunstâncias que envolvem a sua realização, o que introduz um dinamismo na história que concede um aspecto difuso à repetição, apesar de toda a sua abrangência e importância.

A última repetição oscilatória que é concentrada num único personagem e nos dedicaremos a analisar é aquela que é estabelecida entre Zeno e Bigioni no texto Umbertino. Por um lado, como já assinalamos, esse personagem é um rival edipiano do protagonista devido à restrição da liberdade que lhe impõe por interromper as suas leituras e audições; por outro lado, Bigioni é uma esperança para Zeno porque deseja casar com a sua filha (2004, p. 1167-1168), o que proporcionaria um drástico final ao persistente luto dela e, portanto, à humilhante derrota para o genro já falecido no que tange à competição sexual por Antonia. A novidade dessa repetição é que, ao invés de ser caracterizada por mudanças descontínuas que a dividem em etapas, ela é marcada por uma contínua diminuição da ligação favorável a Bigioni simultaneamente com o crescimento das hostilidades contra ele conforme muda a atitude de Antonia:

Il curioso era che come si allontanava dal giorno della morte del povero Valentino il suo [de Antonia] contegno con l' amico dello stesso si faceva più duro. [...] Pareva facesse delle esperienze per scoprire con esattezza il punto a cui poteva giungere senza buttarlo fuori [...].

E debbo dire che tutti noi seguimmo il suo esempio, cercando cioè il punto a cui potevamo arrivare con lui senza buttarlo fuori di casa. Prima di tutti io. (2004, p. 1173)

Assim, a filha trata cada vez pior o pretendente, o que diminui a esperança de Zeno e torna mais frequentes as confissões de Bigioni que interrompem as atividades do protagonista e, portanto, aumenta o principal fator de rivalidade entre eles. Associada à mudança contínua, outra novidade da repetição oscilatória em análise é o seu comportamento assintótico: apesar da esperança no casamento ser cada vez menor e a 
hostilidade contra o pretendente, cada vez maior, jamais é atingido o limite no qual Zeno se recuse a receber Bigioni para não ser interrompido e a lhe dar esperança de que a filha se torne mais favorável ao seu desejo por ela. Tal relação assintótica é curiosamente refletida na conclusão que Clara, a irmã de Valentino, provê para o modo de lidar com Bigioni:

Io l'amai specialmente per il suo contegno col Bigioni. Io m'aspettavo che come sorella di Valentino avrebbe aiutato a gettarlo fuori di casa. Invece essa fu con lui ferma ma cortese. [...] pensava che prima o poi una giovine donna come Antonietta avrebbe finito con lo sposarsi. E allora era meglio lo facesse col Bigioni ch'era stato un sincero amico di Valentino che con un altro. Ma il Bigioni sbagliava di certo volendo avere tanto presto quello che non gli spettava. Ora il compito suo e di tutti noi era di tenerlo a bada e riservalo per epoche migliori.

Ne fui incantato. (2004, p. 1179-1180)

Logo, o incômodo causado pelo Bigioni é encerrado sem terminar com a esperança de que ele case com Antonia desde que novas tentativas de realizá-la sejam postergadas por um prazo completamente indeterminado, já que era justamente a proposta de casamento que criou a esperança de Zeno no fim de um luto que se notabiliza por não dar sinais de esmorecimento por mais que o tempo passe.

Tanto a incapacidade de Zeno para se recusar a receber Bigioni quanto os elogios que concede na última citação à solução dada por Clara nos remetem ao assunto da próxima seção deste capítulo.

\subsection{A interrupção da repetição e a tendência a evitá-la}

É intrínseco à noção de compulsão repetitiva que a interrupção da repetição seja uma questão privilegiada. Comecemos pela tendência a evitar tal interrupção, o que é uma consequência direta de se tratar de uma compulsão. De fato, a seção anterior apresenta situações nas quais Zeno defende de modo obstinado uma das suas repetições, seja no romance, seja nas "continuações".

No tocante ao romance, ao analisarmos as etapas da relação com Carla, nos referimos à sétima delas como sendo a dos esforços desesperados de Zeno para evitar a ruptura definitiva com a amante: apesar do claro anúncio do casamento com Lali, o protagonista ainda tenta, contra todos os indícios, recuperar a relação com Carla ou pelo 
menos se manter ligado à mãe lhe oferecendo um sustento mensal, o qual é recusado, e deixando aberta a possibilidade de que ela o procure caso mude de ideia. Quanto às “continuações”, o caso em questão é o de Bigioni, a quem Zeno é incapaz de dispensar porque seria uma renúncia à competição sexual com Valentino que o desejo de Bigioni por Antonia proporciona, ainda que haja uma contínua diminuição da ligação favorável ao pretendente. Logo, essa repetição oscilatória se torna assintótica pela incapacidade do protagonista de encerrar as suas recorrências edipianas. Também é ela que faz Zeno gostar tanto da solução dada por Clara, pois consegue conservar Bigioni como potencial pretendente de Antonia antes que a rudeza crescente com qual é tratado o fizesse desistir definitivamente.

Dentre as interrupções de repetição que Zeno evita, a de maiores consequências para a sua história é a do desejo por Ada quando ela rejeita o seu pedido de casamento. Para isso, faz o mesmo pedido para Alberta e depois para Augusta, o que lhe permite manter uma ligação com Ada e, portanto, a expectativa de ainda conseguir satisfazer o seu desejo por ela. Essa característica de evitar um fim indesejado já era ressaltada por Saccone:

[...] il successo (se si può chiamare tale un compromesso) nevrotico di Zeno, la sua riuscita nell'evitare una conclusione definitiva, emerge bene da un passo come il seguente, dalle pagine in cui è narrato il rifiuto di Ada: "Quando, tardi, la compagnia si sciolse, Augusta lietamente disse: -A domani! -L'invito mi piacque perché provava che avevo raggiunto il mio scopo e che niente era finito e tutto avrebbe continuato il giorno appresso". (1973, p. 35)

Prosseguindo ainda com a reação do protagonista à recusa de Ada e a citação supra, consideramos que a obstinação em evitar a interrupção da repetição é um momento privilegiado para abordarmos a defasagem entre presente e passado na repetição do recalcado. De fato, o contraste entre Augusta e Zeno na última citação ilustra bem a questão: ela se despede dele acenando para o futuro, o do noivado de ambos, ao passo que ele pensa na continuação do dia de então, o do desejo pela irmã. Assim, a reação à recusa de Ada cria um enorme descompasso temporal entre Zeno, que continua a viver numa situação que concretamente ficou no passado, e ela própria, Augusta e Guido, que assumem plenamente o novo presente dos noivados e depois dos casamentos, deixando a situação anterior definitivamente no passado. A confusão entre as duas irmãs, que abordamos ao tratar da relação com Carla, também é bastante instrutiva no que tange a essa duplicidade temporal, pois o protagonista vive a relação presente com a esposa na medida em que persiste a ligação com Ada, que está relegada 
ao passado desde o momento da recusa. Por fim, acrescentemos uma citação que trata metaforicamente dessa temporalidade dupla em termos das dificuldades de Zeno para tocar violino:

\begin{abstract}
Se tuttavia continuo a sonare, lo faccio per la stessa ragione per cui continuo a curarmi. Io potrei sonare bene se non fossi malato, e corro dietro alla salute anche quando studio l'equilibrio sulle quattro corde. C'è una lieve paralisi nel mio organismo, e sul violino si rivela intera e perciò più facilmente guaribile. Anche l'essere più basso quando sa che cosa sieno le terzine, le quartine o le sestine, sa passare dalle une alle altre con esattezza ritmica come il suo occhio sa passare da un colore all'altro. Da me, invece, una di quelle figure, quando l'ho fatta, mi si appiccica e non me ne libero più, così ch'essa s'intrufola nella figura seguente e la sforma. ${ }^{42}(2004$, p. 742$)$
\end{abstract}

Voltaremos a abordar especificamente a defasagem temporal da repetição no quarto capítulo do presente trabalho, no qual apresentaremos a menção mais extrema do romance a essa questão.

Por fim, ainda falta examinarmos qual é a consequência de o protagonista ser impedido de manter uma repetição, seja no romance, seja nas "continuações". No primeiro caso, há quatro momentos nos quais essa consequência é um componente importante da diegese. O primeiro deles é o da morte do pai no capítulo quarto, cujo resultado ainda reverba intensamente no início do capítulo seguinte: "La mia vita non sapeva fornire che una nota sola senz'alcuna variazione, abbastanza alta [...], ma orribilmente tediosa. [...] Può perciò essere che l'idea di sposarmi mi sia venuta per la stanchezza di emettere e sentire quell'unica nota"43 (2004, p. 685). Como já não há menção a uma disposição tediosa desde o estabelecimento da relação com Giovanni, avaliamos que o fim da rivalidade contra o pai instaura uma condição de tédio que se impõe à repetição e que só será superada com a substituição da figura paterna por Giovanni. Aproveitemos a metáfora sonora da citação para dar o nome de temporalidade da nota única à configuração temporal que substitui a da repetição pela imposição do tédio.

Retrocedendo para o quarto capítulo, reencontramos a questão da vida tediosa

\footnotetext{
${ }^{42} \mathrm{Se}$, apesar disso, continuo a tocar, faço-o pela mesma razão por que continuo a me tratar. Poderia tocar bem se não estivesse doente e corro atrás da saúde mesmo quando pratico o equilíbrio nas quatro cordas do violino. Há uma leve paralisia no meu organismo que se revela em sua integridade quando toco violino e por isso é mais facilmente curável. Até o ser mais rude, quando sabe o que são as terças, as quartas e as sextas, passa de umas às outras com exatidão rítmica como a sua vista sabe passar de uma cor a outra. Comigo, ao contrário, quando executo uma daquelas figuras, a ela me apego e não me liberto mais, e assim ela se intromete na figura seguinte e a deforma (2006, p. 117-118).

${ }^{43}$ Minha vida constituía-se de uma única nota, sem variações, certamente alta [...], mas horrivelmente tediosa para mim. [...] Daí talvez ter-me vindo a ideia de casar-me apenas pelo cansaço de emitir e ouvir aquela mesma nota (2006, p. 67).
} 
na forma da problematização do futuro devido à ausência de propósitos que resultaria da morte paterna, o que Zeno aborda no início do agravamento da doença do pai (2004, p. 667), perto dos seus instantes finais (2004, p. 681) e depois do falecimento (2004, p. $654)$.

O segundo momento do romance no qual é importante diegeticamente o impedimento de manter uma repetição permance apenas como antecipação do protagonista, como nos dois casos anteriores ao falecimento do pai que mencionamos no parágrafo anterior. Estamos nos referindo ao fato de a ruptura definitiva com Ada ser previamente concebida pelo protagonista, em duas ocasiões ao procurar Giovanni para lhe pedir a filha em casamento, como um tempo parado (2004, p. 722-724), outra figura do tédio inerente à temporalidade da nota única. O terceiro momento ocorre durante o período inicial de vida conjugal com Augusta, após ser impedido pelo sogro e pela esposa de continuar a trabalhar na empresa com Olivi. Sem conseguir estabelecer alguma repetição pela qual se oponha a esse impedimento, Zeno é tomado pelo tédio:

Poi nella mia stanzetta magnificamente organizzata venne talvolta la noia.
Era piuttosto un'ansia perché proprio allora mi pareva di sentirmi la forza di
lavorare, ma stavo aspettando che la vita m'avesse imposto qualche compito.
Nell'attesa uscivo frequentemente e passavo molte ore al Tergesteo o in
qualche caffè.
Vivevo in una simulazione di attività. Un'attività noiosissima. ${ }^{44}$ (2004, p.
$800)$

Zeno sai dessa situação tediosa por intermédio de Carla, com quem trairá Augusta. A traição funciona como uma hostilidade edipiana contra a esposa e, por meio dela, contra o sogro. Desse modo, o protagonista retoma a repetição da rivalidade contra os que decidiram que ele deveria parar de trabalhar na empresa com Olivi. De fato, o texto possui três trechos (2004, p. 812-815) que sugerem uma relação praticamente causal do desejo por Carla com o ócio e o tédio aos quais Zeno foi relegado ao ser impedido de trabalhar com Olivi.

O quarto e último momento do romance no qual é importante diegeticamente o impedimento de manter uma repetição está no final do sétimo capítulo com a perda de Ada, que parte para Buenos Aires a fim de viver com a família do marido. O protagonista quase sofreu essa perda quando a cunhada rejeitou o seu pedido de

\footnotetext{
${ }^{44}$ Meu refúgio magnificamente organizado era vez por outra visitado pelo tédio. Tratava-se mais de uma ânsia, pois, embora me sentisse com forças para trabalhar, estava sempre à espera de que a vida me impusesse alguma tarefa. Nessa expectativa saía muitas vezes e passava horas seguidas no Tergesteo ou num café.

Vivia numa simulação de atividade, uma atividade aborrecidíssima (2006, p. 170).
} 
casamento, mas conseguiu evitá-la casando com Augusta, o que é relatado no fim do capítulo quinto. Além de ser a ruptura desse sucesso anterior em evitar o afastamento definitivo de Ada, a partida da cunhada retoma o encerramento do quarto capítulo (notemos, de passagem, que o quinto capítulo também termina de modo semelhante, uma vez que relata a ruptura definitiva com Carla e a manutenção da repetição oscilatória iniciada com ela pela sua substituição por prostitutas), pois a perda de Ada é tão definitiva quanto àquela provocada pela morte do pai de Zeno.

A ligação entre as perdas do pai e da cunhada é expressa textualmente por meio do último período do sétimo capítulo (2004, p. 1047), “Ecco ch'essa ci abbandonava e che mai più avrei potuto provarle la mia innocenza", 45 cujas palavras ressoam outras presentes no romance: “La frase suona identica all'altra che troviamo verso la fine del capitolo dedicato alla morte del padre: 'Egli era morto ed io non potevo più provargli la mia innocenza"” (SACCONE, 1973, p. 11-12).

No caso das "continuações", a temporalidade da nota única é um componente importante da diegese dos textos Un contratto, Il mio ozio e Prefazione. Ela também é crucial para as conclusões da história do texto Le confessioni del vegliardo, mas isso só é estabelecido com mais clareza por meio do narrador, de modo que adiaremos tal tarefa para nos incumbirmos dela no quinto capítulo do presente trabalho.

O tédio do protagonista no texto Un contratto é registrado em dois momentos. No primeiro, surge como resultado da constatação do próprio Zeno de que não é mais capaz de dar alguma orientação comercial que seja válida ao filho de Olivi, o qual está administrando o negócio para o patrão: "A forza di governare e non regnare io presto non seppi più nulla dei miei affari. Quando per caso mi avveniva di dare qualche consiglio venivo subito deriso. [...] Io cominciavo sinceramente ad annoiarmi in quell'ufficio" (2004, p. 1094). No segundo, Zeno simplesmente exclama de tédio logo após assinar o novo contrato com o administrador (2004, p. 1112). Assim, a instauração da temporalidade da nota única nesse texto está associada à crescente incapacidade do protagonista manter a repetição de rivalidade com o filho de Olivi por não descobrir um modo de derrotá-lo, o que atinge um impasse final na recusa a simplesmente voltar ao escritório porque significaria trabalhar sem receber nenhum salário (2004, p. 1112) conforme estava estipulado no novo contrato ao qual sucumbira, o que por si só representaria mais uma vitória do rival.

\footnotetext{
${ }^{45}$ Ia-se sem que jamais lhe pudesse provar minha inocência (2006, p. 387).
} 
Assim como a rivalidade com o filho de Olivi é interrompida pelo impasse criado pelo novo contrato a que o protagonista é submetido, a relação com Felicita, narrada no texto Il mio ozio, estabelece um impasse no desejo de Zeno pelas mulheres. De fato, ele afirma que foi educado por Felicita à velhice e enumera diversas mudanças posteriores a essa educação (2004, p. 1219-1220): não teve outros amores; não declarou mais os seus sentimentos às mulheres com as quais permanecera por mais de dez minutos, ao contrário de como procedia anteriormente com a finalidade de sentir melhor a vida e o seu pertencimento a ela; aprendeu que no amor só vale por aquilo que paga; e a sua feiúra lhe é sempre presente. Novamente adotamos o questionamento sobre o propósito como indício mais direto da temporalidade da nota única, o que avaliamos ocorrer no trecho no qual, no próprio dia no qual escreve o relato, Zeno, após pensar em Felicita, faz uma confissão oculta para Augusta, segundo a qual expressa a ausência de propósito resultante do impasse sexual no qual se encontra: “- [...] non si capisce perché si nasca, si viva e si divenga vecchi -. Così le avevo detto proprio tutto senza compromettermi affatto" (2004, p. 1220).

Zeno ainda faz tentativas que aproxima da abordagem homeopática de Samuel Hahnemann devido às doses reduzidas, uma vez que quase todas estão limitadas ao olhar e não devem revelar o seu objetivo sexual, mas os obstáculos são tão restritivos que impedem a superação do impasse: "Anche qui la dosatura si fa anche più avara di quello che io e Hahnemann vorremmo" (2004, p. 1220).

Mencionemos também uma referência sumária à inércia na qual o protagonista se encontra, a qual é feita no texto Prefazione ao tratar de um problema de medição temporal: "Ho pensato tanto a lungo a questo problema che persino la mia vita inerte mi diede l'occasione ad un'esperienza che potrebbe chiarirlo [...]" (2004, p. 1229).

Por fim, verifiquemos qual é o estado de ânimo de Zeno antes do encontro excepcional com a moça que ele confunde com a filha do velho Dondi, conforme está descrito no início do texto Prefazione:

Rincasavo di sera in automobile [...] ero incline al riposo. Non al sonno ma all'inerzia. Mi trovavo lontano dalle cose che mi circondavano e che tuttavia lasciavo arrivare a me perché nulla le sostituiva: Andavano via prive di senso. [...] tanto conosciute [elementos da paisagem] che arrivavano previste, e guardarle era poco meno che dormire. (2004, p. 1222)

Apesar de Zeno estar num carro em movimento - um símbolo trivial da velocidade da vida moderna -, a descrição enfatiza a falta de movimento e de mudança e, portanto, é altamente compatível com o tédio da temporalidade da nota única. Assim, 
Zeno está propenso ao repouso, mas não se trata de sono, o qual é afastado no início e no fim da citação. Além disso, as coisas ao redor estão vinculadas a essa condição tediosa por não lhe trazerem nenhuma novidade ou por estarem privadas de sentido, pois não o interessam nem ele se demonstra capaz de lhes impor algo próprio que crie algum interesse.

Resta-nos apenas assinalar o motivo pelo qual foi instaurada a temporalidade da nota única que permeia a citação supra. Como o episódio da confusão com a filha do velho Dondi (2004, p. 1222-1224) é a única expressão do desejo sexual do protagonista no texto em análise e é referenciado quando Zeno trata da abordagem homeopática pela qual tenta manter o desejo pelas mulheres (2004, p. 1220-1221) no texto Il mio ozio, podemos supor que o motivo que procuramos é justamente o impasse sexual que se estabelece para o protagonista por meio do término da relação com Felicita.

Como nos concentramos no tempo da história no presente capítulo, não abordamos a relação crucial entre a temporalidade da nota única e a atividade de Zeno como narrador, a qual será devidamente analisada nos próximos capítulos deste trabalho. 


\section{Capítulo 3 \\ A REPETIÇÃO DO RECALCADO E A ELABORAÇÃO DAS ARTICULAÇÕES TEMPORAIS NO ROMANCE LA COSCIENZA DI ZENO - OS DOIS CAPÍTULOS INICIAIS E A AUTOBIOGRAFIA}

No presente capítulo, estudaremos os capítulos do romance anteriores ao diário, dos quais investigaremos tanto a presença da repetição do recalcado e da temporalidade da nota única fora da diegese quanto outras temporalidades que se articulam à repetição compulsiva, o que nos possibilitará propor formulações para as articulações temporais que vigoram ao longo dos capítulos em questão com mais abrangência e acurácia do que aqueles encontrados na fortuna crítica de Svevo.

Assim, enquanto a relação entre a noção psicanalítica da repetição do recalcado com a criação literária no capítulo anterior tinha por base a construção do protagonista e a linguagem pela qual Zeno se expressa, a base dessa relação no presente capítulo são o tempo literário, no qual estão imbricados os aspectos temporais da história, da narrativa e da narração, e o narrador, na medida em que a sua elaboração está profundamente vinculada aos tempos da narrativa e da narração, os quais são de grande importância para o terceiro romance de Svevo.

A fim de cumprirmos a tarefa que estabelecemos para este capítulo, faremos uma análise introdutória dos meios pelos quais o romance rompe com a temporalidade linear; trataremos das duas principais relações temporais que compõem o âmbito da experiência manifestada por Zeno como protagonista e narrador; introduziremos a superação desse âmbito da experiência de Zeno; investigaremos qual é a temporalidade que resulta de tal superação; e concluíremos com a exposição das articulações entre as temporalidades que analisamos. As duas primeiras seções se limitarão à autobiografia de Zeno, ou seja, do terceiro capítulo ao sétimo; incluíremos o prefácio e o preâmbulo nas nossas considerações a partir da terceira seção.

\subsection{Uma primeira abordagem do rompimento com a temporalidade linear}

Dedicamos esta seção a uma análise introdutória sobre o rompimento do 
romance com a temporalidade linear, que era a principal configuração temporal das narrativas clássicas. Comecemos pelos aspectos temporais do romance mais comumente destacados pelos seus estudiosos, que são o afastamento da ordenação cronológica e a afirmação de um tempo subjetivo que justapõe dois ou mais intervalos temporais. Justamente por serem tão comumente abordados, nos contentaremos simplesmente em apresentar dois exemplos que abarquem níveis bem diferentes do texto e nos sirvam à consideração posterior de outras questões.

Como primeiro exemplo, usemos o levantamento feito pelo crítico Mario Lavagetto da relação entre as séries dos acontecimentos na história e da sua apresentação narrativa no terceiro capítulo do romance. Ele identificou os vinte e cinco segmentos temporalmente contínuos que compõem a narrativa, nomeados por letras (a propósito, ele esqueceu a letra $\mathrm{W}$ ), e a posição relativa no tempo de cada um dos segmentos, desde 1 para o segmento que narra os acontecimentos mais antigos até 13 para o dos acontecimentos mais recentes (o zero é usado para indicar o presente do narrador). O resultado do levantamento foi:

$\begin{array}{lllccrrrrrrrr}\mathrm{A} & \mathrm{B} & \mathrm{C} & \mathrm{D} & \mathrm{E} & \mathrm{F} & \mathrm{G} & \mathrm{H} & \mathrm{I} & \mathrm{J} & \mathrm{K} & \mathrm{L} & \mathrm{M} \\ 0 & 1 & 0 & 2 & 3 & 4 & 5 & 0 & 6 & 7 & 0 & 6 / 7 & 0 \\ & & & & & & & & & & & & \\ \mathrm{~N} & \mathrm{O} & \mathrm{P} & \mathrm{Q} & \mathrm{R} & \mathrm{S} & \mathrm{T} & \mathrm{U} & \mathrm{V} & \mathrm{X} & \mathrm{Y} & \mathrm{Z} & \\ 6 / 7 & 9 & 10 & 12 & 13 & 11 & 5 & 0 & 5 & ? & ? & 8 & \end{array}$

$(1975$, p. 79$)$

O esquema de Lavagetto torna fácil observar que a cronologia é insistentemente perturbada por intromissões do presente do narrador e por dúvidas quanto à posição relativa de eventos no tempo e, por fim, entra em colapso após o segmento R, quando se passa de um intervalo temporal para outro por saltos bem diversificados. As dúvidas podem ser uma simples indecisão entre duas possibilidades no caso dos segmentos $\mathrm{L}$ e $\mathrm{N}$ ou uma indeterminação mais radical, indicada pelo ponto de interrogação, como ocorre com os segmentos X e Y.

O nosso segundo exemplo do que os críticos destacam abrange um trecho do romance de apenas poucas frases, referente a Carla e Lali:

Cantavano ora insieme delle canzoni sue che mi parvero povera cosa tanto quando amavo Carla quanto allorché la sentivo come una catena. Può tuttavia essere che fossero buone ad onta che io poi non ne abbia più sentito a parlare. Egli diresse poi delle orchestre negli Stati Uniti e forse colà si cantano anche quelle canzoni. ${ }^{46}(2004$, p. 880$)$

\footnotetext{
${ }^{46}$ Cantavam canções de sua autoria, que achei bastante chochas, fosse quando Carla me inspirava amor, fosse quando me parecia um trambolho. Pode ser, contudo, que fossem boas, ainda que nunca ouvisse
} 
Eis como o crítico Giulio Savelli apresenta a multiplicidade temporal do pequeno trecho:

Qui i tempi dei verbi non sono marche dei differenti piani temporali. Questi sono tre: il passato in cui Carla e il suo maestro cantavano delle canzoni da lui composte, Zeno era l'amante di Carla, ed era geloso del Lali [...]; un presente in cui Zeno scrive e in cui, egli ipotizza, negli Stati Uniti si cantano le canzoni scritte dal Lali; un altro tempo, passato rispetto a questo presente ma futuro rispetto al momento in cui Carla e Lali cantavano assieme, in cui Zeno non ha sentito parlare più di queste canzoni e in cui Lali ha diretto delle orchestre negli Stati Uniti. Indubbiamente questo passo è un esempio del "trascorrere continuo da una zona temporale all'altra" col quale "Svevo crea la complessità temporale del suo romanzo". (1998, p. 26)

Sem nos determos mais em análise tão difundida, declaremos apenas que compartilhamos a avaliação generalizada da crítica de que há um afastamento sistemático da cronologia no romance em favor de um tempo subjetivo que é constituído pelos deslocamentos temporais realizados por Zeno. Feita essa consideração preliminar, iniciemos a exposição dos aspectos temporais que operam conjuntamente no sentido de distanciar a nossa perspectiva dessa base comum. Nesta seção, ampliaremos a análise do rompimento com a temporalidade linear para abarcar também a recusa de uma adoção generalizada de duas articulações temporais que introduzimos no primeiro capítulo do presente trabalho: a causalidade e o código hermenêutico.

Comecemos verificando o tratamento dado à relação causal no romance. $\mathrm{O}$ estranhamento que pode provocar é bem enfatizado pelo comentário que Savelli dedica ainda ao mesmo trecho referente a Carla e Lali:

Nel primo periodo si dice che le canzoni del Lali sono sembrate a Zeno "poca cosa". È un giudizio gratuito, nel senso che, buone o cattive, nulla cambiano nella posizione di nessuno dei protagonisti né nella valutazione che il lettore può dare della situazione. Zeno [...] sospetta che il suo giudizio sia stato alterato dall'emozione, e cerca una spiegazione che sia anche una giustificazione: la sua valutazione, dice, è stata indipendente dall'oscillazione dei suoi sentimenti per Carla. Ovviamente, però, non questi sono in gioco, ma quelli verso il Lali. La frase successiva prende atto del fatto che questa spiegazione è sfocata come di troppo è stato il giudizio sulle canzoni, e precisa: "può tuttavia essere che fossero buone". Ma Zeno non resiste a correggere questa concessione con un dubbio: "ad onta che io poi non ne abbia più sentito a parlare": quindi tanto buone non dovevano poi essere se non hanno avuto successo. Ma anche questa congettura è sospetta per lo scrupolo di Zeno [...]

Ma ciò che colpisce maggiormente, in questa discussione riguardo l'effetto della gelosia di Zeno sulla lucidità del suo giudizio musicale, è la perfetta gratuità. Sembra sia in ballo la verità circa il talento del Lali, in effetti è in ballo la verità circa gli effetti della gelosia sulla facoltà di Zeno di giudicare,

depois falarem delas. O homem foi mais tarde reger orquestras nos Estados Unidos e talvez por lá até cantem essas canções (2006, p. 242). 
ma già sappiamo che Zeno è stato geloso, e lo sa lui stesso: lo sta dicendo in modo assolutamente esplicito da mezza pagina. Perché allora gioca con se stesso come se non volesse ammetterlo? (1998, p. 26-27)

Complementarmente à desorientação produzida pela reunião um tanto improvisada de julgamentos pelo narrador, há várias intervenções suas que introduzem elementos sem que sequer se tente desenvolver a razão pela qual isso é feito. Exemplifiquemos esse caso com duas intervenções presentes no episódio com a mãe no sofá: a menção à divisão da sala na qual brincava com o irmão (2004, p. 630) apresenta uma associação entre os tempos da história e da narração que não recebe nenhum desenvolvimento, e a ligação entre dois momentos da história feita ao declarar que reencontrou o sorriso materno nos lábios da esposa (2004, p. 630-631) não será retomada por Zeno apesar de o sorriso de Augusta ser mencionado diversas vezes (citamos e examinamos duas delas no capítulo anterior). No tocante à causalidade, o resultado da acumulação de tais lacunas explicativas por parte do narrador é o enfraquecimento causal do texto. Tais intervenções e o exemplo que Savelli comenta serão retomados por nós na penúltima seção do presente capítulo para que os analisemos com maior abrangência e sob outra perspectiva.

Uma vez que tratamos da causalidade no que se refere ao narrador, nos concentremos no enredo, que apresenta vários casos de debilidade causal na sua composição. Como exemplo do alcance de tais casos, retomemos o esquema temporal de Lavagetto para o terceiro capítulo a fim de estudar as conexões que o enredo estabelece entre os sucessivos segmentos temporais da vida do protagonista. Há uma parte inicial que vai até a doença que exige que Zeno fique acamado, o que ocorre no segmento $G$, e é constituída por uma progressão que descreve as mudanças na propensão do protagonista para fumar. Cada segmento da parte inicial possui uma dependência minimamente causal com a cadeia dos segmentos anteriores.

Após o começo com alguma organização causal, o terceiro capítulo não apresenta mais nenhuma mudança na conduta do protagonista como fumante na medida em que ele está sempre alternando entre fumar e buscar uma oportunidade para cessar de fumar após um último cigarro. Tampouco o enredo fornece dependências causais que liguem os segmentos (na presente análise, não há porque diferenciarmos os segmentos $\mathrm{T}$ e V, pois tratam do mesmo intervalo temporal numerado como 5, interrompido apenas por um comentário do narrador), exceto no caso daqueles rotulados como I e J, pois Zeno só pode abandonar o curso de química para voltar a cursar direito já tendo feito o 
caminho contrário (2004, p. 632-633). Isso significa que quaisquer outros dois segmentos da parte em análise do capítulo estão ordenados no tempo da história por indicações meramente cronológicas, como uma data, uma época, a idade de um personagem ou a relação imediata de antecedência, simultaneidade ou sucessão com respeito a um evento da história humana ou do romance. Logo, o enredo pretende assegurar a causalidade apenas em dois grupos de segmentos diegéticos, os de B a G e o par formado por I e J, e não expõe vínculos causais entre os demais.

Para finalizar a nossa análise da causalidade na presente abordagem inicial do rompimento com a temporalidade linear, destaquemos o apelo direto do texto a figuras de oposição à ligação causal comentando algumas das suas principais ocorrências. Como primeira delas, examinemos a ideia de originalidade da vida (2004, p. 972). Após Guido declarar que a vida é injusta e dura, o protagonista faz a própria escolha e qualifica a vida como original. Assim, a escolha de Zeno recai justamente numa qualificação que afasta o domínio da causalidade. Além disso, há um comentário que sugere que essa ideia foi produzida por uma associação casual.

Outras ocorrências de figuras de oposição à ligação causal estão baseadas no recurso à superstição, a qual é uma crença irracional e, portanto, não pode estar sustentada em relações de causalidade. Como exemplos do comportamento supersticioso de Zeno destacamos os "últimos" cigarros baseados no início ou fim de eventos externos e principalmente nas relações numéricas das datas (2004, p. 634); o pressentimento, análogo ao da mesa de jogo, para decidir operações de compra ou venda da empresa que Olivi administra (2004, p. 797-799); e a ação de "chorar" o valor das ações, como se fossem cartas de baralho, no episódio do jogo na bolsa de valores após o suicídio de Guido (2004, p. 1033-1045).

Por fim, tratemos de três transições temáticas que estão baseadas em figuras de oposição à ligação causal. As duas primeiras operam com a descoberta casual feita pelo narrador de uma data de um último cigarro anotada num livro. Logo, a transição entre os assuntos narrados é determinada por um acaso ocorrido no tempo da narração. É desse modo que um assunto inteiramente novo - a troca dos estudos de direito para os de química - entra na narrativa após o narrador encontrar um registro da data do último cigarro dedicado a essa troca num dicionário (2004, p. 632). Como não é dito que ele procurava tal registro, o acaso se torna um fator do que será incluído na narrativa, como se fosse sugerido que se Zeno não houvesse encontrado esse registro, a troca de estudos não seria relatada dentro do histórico do vício. A segunda transição realizada pela 
descoberta casual em análise se encontra logo após Zeno anunciar que tratará do pai no quarto capítulo: “"15.4.1890 ore 4 1/2. Muore mio padre. U. S.'. Per chi non lo sapesse quelle due ultime lettere non significano United States, ma ultima sigaretta. È l'annotazione che trovo su un volume di filosofia positiva"47 (2004, p. 653). Assim, o relato sobre o pai é submetido a uma radical inversão cronológica ao ser iniciado pela referência à sua morte, a qual é seguida pela menção a efeitos que causou em Zeno, e o único motivo que o narrador sugere para essa inversão é o acaso de encontrar a anotação da data. Exploraremos outros aspectos da antecipação da morte do pai ainda neste capítulo.

A terceira e última transição temática para a qual desejamos ressaltar a oposição a conexões causais é a apresentação de um novo assunto, o do casamento no início do quinto capítulo; mais precisamente, na época anterior ao encontro do protagonista com as filhas de Giovanni. Zeno desvincula o casamento, em termos de causalidade, de duas ações que realiza nessa época, apesar da sua importância para o futuro matrimônio: a ligação com o futuro sogro e o rompimento de uma antiga relação amorosa. De fato, Zeno inicialmente evoca o destino ao comentar a ausência de vínculo causal delas com o fato de pretender se casar (2004, p. 686) e depois recorre ao próprio acaso quando relata o rompimento amoroso com mais pormenor (2004, p. 693). Além de enfatizar a ausência de vínculo por meio do destino e do acaso, Zeno apresenta uma causa para a sua opção pelo casamento, mas isso já envolve outras questões, que analisaremos na antepenúltima e penúltima seções deste capítulo.

Uma vez que examinamos as lacunas da causalidade, encerremos a presente seção analisando como a narrativa se afasta do código hermenêutico. Svevo enfraquece sistematicamente o controle das expectativas segundo tal código por meio de uma prolepse ou de uma informação referente ao tempo da narração que antecipa algum fato crucial da história em todos os capítulos da autobiografia. Além disso, como nenhum código hermenêutico é mobilizado para desestabilizar a informação antecipada, constantemente ratificada pelo rumo dado ao enredo, o resultado é um enfraquecimento decisivo do estabelecimento de um suspense ou uma tensão que seja sustentada ao longo da condução da narrativa. Em prol das nossas considerações, apresentemos cada uma dessas antecipações.

\footnotetext{
47 "15.4.1890, às 4 e 30. Meu pai morreu. U. S." Para os menos avisados as duas últimas letras não significam United States, mas última sigaretta [último cigarro]. É a anotação que encontro num volume de filosofia positiva (2006, p. 39).
} 
No terceiro capítulo, o narrador informa que ainda sofre com o distúrbio dos "últimos" cigarros logo após relatar o seu início (2004, p. 632). Isso impede os leitores de criarem a expectativa crucial sobre um eventual fim do distúrbio, e faz com que, tão logo reconheçam que Zeno está contando mais um caso de um último cigarro ou mais uma tentativa de parar de fumar, eles não criem nenhuma expectativa de que seja narrada alguma mudança na situação do fumante. No capítulo seguinte, a antecipação está no próprio título, pois a morte do pai é o seu principal acontecimento, em torno do qual se organizam os demais eventos, exceto um pouco mais de uma dezena de parágrafos dedicados à convivência entre pai e filho (2004, p. 654-657): antes deles, Zeno trata das consequências desse acontecimento para a sua vida; depois deles, apresenta uma sequência que é teleologicamente baseada nesse falecimento e consiste no episódio do testamento, nas manifestações da doença fatal e finalmente na morte e no enterro do pai.

Ainda nas páginas iniciais do quinto capítulo, há uma prolepse na qual Zeno anuncia que Ada casou com outra pessoa (2004, p. 688) antes mesmo de narrar o encontro com as filhas de Giovanni. Logo, o relato central do capítulo, o do desejo intenso do protagonista por Ada e dos seus esforços para casar com ela, é inteiramente feito já com a informação de que Zeno não será exitoso. No capítulo seguinte, cujo principal e mais duradouro elemento do enredo é o relacionamento extraconjugal de Zeno com Carla, há uma prolepse que anuncia tanto o fim dessa relação quanto o fato de que a amante não tentará prejudicar Zeno ainda no terceiro encontro entre eles (2004, p. 834-835), que é o primeiro na condição de amantes (o segundo encontro só consolida essa condição com o beijo que ocorre quando Zeno se despede). Essa prolepse esvazia duas das expectativas mais imediatas de uma relação extraconjugal; talvez a única comparável a elas seja a questão da descoberta da traição, a qual tampouco é elaborada segundo um código hermenêutico, ainda que não seja neutralizada como as demais.

No tocante ao sétimo capítulo, uma prolepse sobre o resultado da empresa de Guido aparece já nas primeiras páginas, antes mesmo de começar o relato das suas primeiras atividades: Zeno nos informa que a sua contribuição à empresa de Guido não deu fruto a nenhum dos dois e até declara que apenas a sorte impediu que o concunhado o arruinasse (2004, p. 912). Esses indícios do fracasso da empresa jamais são desmentidos; pelo contrário, a própria história continuamente enfatiza a incompetência de Guido para os negócios e o pouco interesse que lhes dedica. Assim, toda a narrativa da atividade empresarial na qual os concunhados se empenham, que dura quase o 
capítulo inteiro, transcorre tendo como horizonte o seu resultado fracassado.

Com base nos aspectos temporais que abordamos na presente seção, consideramos que, de um modo geral, o romance rompe com a temporalidade linear; entretanto, também consideramos que tal avaliação está muito longe de exaurir a complexidade temporal do romance. O restante deste capítulo justamente será dedicado a tratar dos demais elementos importantes para compreender tal complexidade, os quais estão intimamente articulados com o rompimento que estudamos nesta seção.

\subsection{As relações temporais no âmbito da temporalidade manifestada por Zeno: o embate entre as temporalidades linear e de onda}

Dedicaremos esta seção a compreender quais são duas principais relações temporais que encontramos na autobiografia de Zeno ao considerarmos a temporalidade manifestada por ele. Logo, não abordaremos na presente seção a repetição e a temporalidade da nota única, que Zeno só reconhece em algumas oportunidades, como comentamos no capítulo anterior.

Para atingirmos o objetivo proposto, analisaremos a temporalidade manifestada por Zeno como uma articulação entre a aceitação e a recusa da temporalidade linear. Como já introduzimos o rompimento com a linearidade temporal na seção anterior, a primeira etapa da nossa análise abordará os principais aspectos pelos quais a temporalidade linear ainda é adotada na autobiografia de Zeno. A segunda etapa se dedicará a superar esses resultados prévios investigando propriamente a articulação que mencionamos. Concluiremos explorando como podemos derivar duas alternativas de configurações temporais da investigação que realizamos na etapa anterior.

Antes de iniciarmos as três etapas nas quais dividimos a presente seção, introduzamos sumariamente a contraposição frente a abordagem que adotamos na seção prévia. De fato, a simples proposta de que precisamos examinar a temporalidade linear relativiza o rompimento que estudamos na seção anterior e opõe o presente trabalho àqueles que desprezam os aspectos lineares do tempo no romance como se fossem meramente acessórios ou uma espécie de fundo que serviria apenas para delinear a figura do que realmente importa; pelo contrário, consideramos que a escrita de Zeno 
efetivamente tenta se compor segundo essa temporalidade, o que podemos aproximar de um comentário de Lavagetto (2000 p. 265) que citamos no primeiro capítulo, segundo o qual Zeno escreve sobre a própria história tentando entender a si mesmo, de modo que se esforça para estabelecer uma série de relações de ordem cronológica.

A primeira etapa da nossa análise será dedicada aos maiores segmentos textuais da autobiografia que são explicitados pelo próprio discurso, a saber, os capítulos nos quais está dividido, o que fazemos devido ao nível máximo de segmentação ser o de maior êxito na adoção da temporalidade linear. No tocante à cronologia, podemos verificar facilmente o quanto ela predomina nos capítulos: Zeno começa a fumar muitos anos antes da morte do pai; conhece a família Malfenti e se casa com Augusta após o pai morrer; a vida com a esposa e Carla é obviamente posterior ao casamento; e começa a trabalhar com Guido após já estar com Carla. Logo, a sucessão dos inícios dos capítulos é perfeita; só aparecem imperfeições cronológicas ao considerarmos os finais: quando Zeno termina com Carla, ele já está trabalhando com Guido e, principalmente, Zeno fuma até o momento da narração e alguns eventos narrados no terceiro capítulo, como a internação na clínica do doutor Muli, são posteriores à morte de Guido.

A linearidade da temporalidade instaurada pelos capítulos não se esgota na cronologia. De fato, a curva autobiográfica construída por eles está - com a contraposição da doença, cujo andamento seria mais adequado a uma lógica burguesa se fosse curada pelos médicos ou houvesse provocado a morte de Zeno - em conformidade com a temporalidade intrínseca à ordem burguesa, a qual lhe empresta uma aparência de progressão lógico-causal: a morte do pai está acoplada à necessidade de o homem deixar a família de nascimento para formar a própria por meio do casamento, ao qual é inerente as amantes que possui um marido rico, e para a qual deve prover o sustento por meio de uma atividade econômica. A construção de biografias segundo um modelo fortemente articulado é um fenômeno literário muito antigo. O teórico Mikhail Bakhtin o encontra em obras de Platão sobre Sócrates, sobre as quais declara pertencerem ao cronotopo "o caminho de vida do indivíduo que busca o verdadeiro conhecimento". Sobre esse cronotopo, ele afirma:

A vida desse indivíduo que busca desmembra-se em épocas ou níveis precisamente limitados. O caminho passa pela ignorância presunçosa, pelo ceticismo autocrítico e pelo conhecimento de si mesmo para o verdadeiro conhecimento (Matemática e Música).

[...] O tempo biográfico real está, aqui, quase totalmente dissolvido no tempo ideal e mesmo abstrato dessa metamorfose [as mudanças de nível]. (1993, p. 
Ora, os capítulos da autobiografia de Zeno (exceto o primeiro deles) são os níveis do caminho de vida do burguês, de modo equivalente ao cronotopo que citamos.

A adoção de uma temporalidade socialmente reconhecida e que efetivamente constitui a história dos demais personagens também garante que a leitura seja guiada por expectativas e, portanto, projete previamente como se dará a progressão da narrativa; por exemplo, o marido rico poderá manter uma amante desde que ela não seja descoberta pela esposa, a qual agirá para manter o casamento, geralmente tentando romper a relação extraconjugal, como efetivamente ocorre nos casos do pai de Zeno (2004, p. 655-656), Giovanni (2004, p. 696-697) e Guido, tanto no que se refere a uma empregada doméstica (2004, p. 893-894) quanto no caso de Carmen, que é um assunto que se desenvolve ao longo de boa parte do sétimo capítulo.

Como resultado da presente etapa da nossa análise, consideramos que a macrossegmentação dos capítulos da autobiografia adota, com poucos desvios, a temporalidade linear.

A segunda etapa da nossa análise aprofundará a investigação da temporalidade linear na autobiografia no sentido de superar os dois resultados particulares que já obtivemos no presente capítulo: o alto grau de adoção dessa temporalidade na organização geral dos capítulos e o rompimento com ela em variados níveis do texto, conforme resulta do nosso estudo na primeira seção. De fato, mesmo a etapa anterior já expôs os desvios das articulações temporais entre os capítulos em relação à linearidade. Assim, dedicaremos esta etapa à tensão entre a adoção da temporalidade linear e o seu rompimento como constituinte da autobiografia de Zeno, sempre partindo do que abordamos na primeira seção.

No tocante à cronologia, retomemos o esquema temporal de Lavagetto para o terceiro capítulo. Para construir esse esquema, o crítico se limita a aplicar os estudos de Genette sobre as relações de ordem temporal entre a história e a narrativa, o que traz riscos de desconsiderar aspectos relevantes para a situação concreta em análise, mas abstraídos da perspectiva teórica do autor francês. De fato, uma diferença relevante entre os segmentos do esquema é desconsiderada: o último deles, o episódio do doutor Muli, não pode ser tratado como os demais, pois é muito maior do que qualquer outro (quase a metade de todo o capítulo). Por ser relatado cronologicamente, o último segmento recupera a cronologia que havia sido abolida no segmento $\mathrm{S}$ por meio de 
anacronias e até de acronias, de modo que uma apreciação mais precisa do capítulo no que tange a essa ordenação é a de que é composto por dois blocos em grande medida cronológicos - ainda que possuam frequentes ocorrências do presente do narrador -, separados por um bloco que interrompe essa disposição e é o menor dentre os três.

Em suma, tal como no caso da organização temporal intercapítulos, consideramos que a tendência à cronologia predomina como andamento geral da narrativa e, ao mesmo tempo, que os desvios cronológicos aparecem com bastante clareza, seja em segmentos isolados, como aqueles que estão no presente do narrador, seja em um grupo de segmentos, tal como o bloco intermediário do terceiro capítulo.

Quanto à causalidade, comecemos retomando o comentário de Savelli ao trecho referente a Carla e Lali. A incapacidade de estabelecer as conexões causais do trecho comentado não se deve à carência de explicações por parte de Zeno, mas antes à proliferação das mesmas sem estarem devidamente articuladas.

Outro exemplo de proliferação de causas que se reverte numa exposição tácita de uma incapacidade explicativa são os quatro trechos próximos no terceiro capítulo (2004, p. 632-635) nos quais Zeno tenta fornecer alguma explicação sobre o seu vício tabagista. Além de nenhuma delas ser propriamente convincente, não há nenhum esforço para fazê-las convergir, de modo que a própria multiplicidade de explicações discordantes produz um efeito de anulamento recíproco que colabora para a debilidade causal do texto.

Retomemos também os recursos à superstição e ao destino. Ao contrário do mero apelo ao acaso, tais recursos ainda pretendem apresentar uma causa, ainda que esteja nos limites de arbitrariedade: a superstição justamente se destaca por ser uma causa que está fora dos padrões vigentes sobre a causalidade, e o destino é paradoxalmente evocado como substituto das causas prováveis que são negadas pelo narrador.

Assim, recuperamos a apresentação causal dada por Zeno a alguns elementos que analisamos na primeira seção segundo o seu efeito de enfraquecimento da causalidade. Tratemos também da situação inversa retomando ligações causais que identificamos nessa seção. Ao estudarmos as conexões causais que o enredo estabelece entre os sucessivos segmentos do esquema temporal de Lavagetto, concluímos que havia muitas lacunas em termos de causalidade, pois tais conexões só eram apresentadas em dois casos: o dos segmentos diegéticos de $\mathrm{B}$ a $\mathrm{G}$ e o do par de segmentos I e J.

No segmento I, o protagonista troca o curso de direito pelo de química 
alegando que o primeiro estaria afastado da vida, mas volta ao direito no segmento $\mathrm{J}$ sem que o motivo alegado para abandoná-lo seja superado, de modo que volta exatamente à situação inicial, e os leitores ficam com a sensação de que a ordem dos cursos é simplesmente arbitrária ou até mesmo de que tanto faz para a história de Zeno se as trocas de curso aconteceram ou não. Esse procedimento de uma justificativa abandonada de modo displicente reaparece em outras oportunidades, como os episódios do doutor Muli e do jogo na bolsa de valores após o suicídio de Guido. No segundo caso (2004, p. 1033-1045), o propalado objetivo de agir em proveito do suicida é perseguido por meio do ousado jogo com as ações, que é justificado por uma atitude de um jogador supersticioso e obstinado, que, mesmo diante de resultados desfavoráveis, acredita que será favorecido e que a força do seu desejo pode interferir no acaso. A confiança nessa atividade supersticiosa é reiterada várias vezes, mas abandona abruptamente o protagonista após a conversa com a viúva, e ele desiste de se arriscar no jogo com as ações. A rigor, a perda pura e simples de confiança poderia ocorrer a qualquer momento, o que incentiva o descarte da justificativa dada aos grandes riscos corridos por Zeno.

Talvez seja o episódio do doutor Muli que obtenha o máximo proveito de uma justificativa abandonada de modo displicente ao usá-la para dar início a uma sequência de ações dentre as de maior encadeamento causal de todo o romance, narrando até mesmo o planejamento e a execução de uma fuga. Zeno começa o episódio reconhecendo duas justificativas para a sua decisão:

\begin{abstract}
Mio figlio aveva da poco compiuti i tre anni quando mia moglie ebbe una buona idea. Mi consigliò, per sviziarmi, di farmi rinchiudere per qualche tempo in una casa di salute. Accettai subito, prima di tutto perché volevo che quando mio figlio fosse giunto all'età di potermi giudicare mi trovasse equilibrato e sereno, eppoi per la ragione più urgente che l'Olivi stava male $\mathrm{e}$ minacciava di abbandonarmi per cui avrei potuto essere obbligato di prendere il suo posto da un momento all'altro e mi consideravo poco atto ad una grande attività con tutta quella nicotina in corpo. $^{48}$ (2004, p. 640-641)
\end{abstract}

A primeira delas é apresentada como a mais importante, mas verifiquemos o modo pelo qual cada uma delas é abandonada:

Da mia moglie ebbi una buona notizia. Ritornando dalla casa di salute s'era imbattuta nel figlio dell'Olivi che le aveva raccontato che il vecchio stava

\footnotetext{
${ }^{48}$ Meu filho acabava de completar três anos quando minha mulher teve uma ideia excelente. Insistiu para que eu me internasse por algum tempo numa casa de saúde, a fim de desintoxicarme. Aceitei incontinenti, primeiro porque queria que meu filho, ao chegar à idade da razão, pudesse considerar-me equilibrado e sereno, e também pela razão mais urgente de Olivi andar adoentado e ameaçar abandonar-me. Tendo eu assim de assumir suas atividades de um momento para o outro, considerava-me pouco apto para tamanha atividade com toda aquela nicotina no corpo (2006, p. 26-27).
} 
molto meglio dopo di aver presa una medicina prescrittagli da un suo nuovo medico.

Addormentandomi pensai di aver fatto bene di lasciare la casa di salute poiché avevo tutto il tempo per curarmi lentamente. Anche mio figlio che dormiva nella stanza vicina non s'apprestava certamente ancora a giudicarmi o ad imitarmi. Assolutamente non v'era fretta. ${ }^{49}$ (2004, p. 652)

A justificativa considerada menos importante deixa de fazer sentido quando Olivi se recupera da doença e é, portanto, apropriadamente abandonada. Por outro lado, a justificativa que seria a mais importante é descartada sem que nenhum fato novo seja introduzido, de modo que Zeno apenas expõe uma opinião contrária àquela que tinha ao decidir aceitar a sugestão de se internar numa casa de saúde. Isoladamente, essa explicação dá uma fachada racional à ação de Zeno, pois possui uma forma de argumentação e se fundamenta numa opinião sobre um assunto para o qual o senso comum não tem uma resposta definitiva. O problema é que Zeno não só havia apresentado a opinião contrária no início do episódio, mas também considerava que ela era a mais importante das duas justificativas que identificava para a sua decisão, o que deixava implícito que estava convencido da opinião inicial. Ora, a maneira como adota uma opinião inversa no final do episódio, sem maiores considerações sobre a mudança de uma para outra, simplesmente invalida a efetividade da causa que haveria originado todo o episódio.

Em suma, o maior trecho causalmente articulado do terceiro capítulo parece ser criado apenas para se revelar um grande fracasso em termos causais, pois toda a cadeia intermediária de conexões fracassa retrospectivamente com a justificativa inicial que é abandonada, e o que parecia ser o ápice da causalidade desse capítulo produz um resultado dominado pela casualidade.

No tocante aos segmentos diegéticos de $\mathrm{B}$ a $\mathrm{G}$, tratemos de um pequeno trecho que nos permite estudar outras formas pelas quais Zeno propõe conexões causais que se revelam insubsistentes em termos do enredo ao serem analisadas criticamente: "Pare che Giuseppe ricevesse molto denaro dal padre suo e ci regalasse di quelle sigarette. Ma sono certo che ne offriva di più a mio fratello che a me. Donde la necessità in cui mi

\footnotetext{
${ }^{49}$ De minha mulher recebi, mas foi uma boa notícia. Ao voltar da casa de saúde, encontrou na rua o filho de Olivi que lhe contara estar o velho muito melhor depois que tomara um remédio prescrito pelo novo médico a quem consultara.

Ao deitar-me, achei que fizera bem em deixar a casa de saúde, pois tinha tempo suficiente para curar-me aos poucos. Meu filho, que dormia no quarto ao lado, ainda não estava certamente em idade de julgar-me ou imitar-me. Não havia pressa absolutamente nenhuma (2006, p. 37).
} 
trovai di procurarmene da me delle altre. Così avvenne che rubai”,50 (2004, p. 628). Há conexões insubsistentes que consistem em fornecer uma condição ou causa provável para um fato, mas que é dispensável para a trama. É o que ocorre no início da citação: é bem provável que, para dar cigarros aos irmãos Cosini, Giuseppe receba muito dinheiro do pai, mas essa informação não acrescenta nada ao enredo. Na verdade, ela poderia ser retirada sem alterar o resto da história narrada.

Outra conexão insubsistente aparece no fim da citação e consiste em simplesmente mencionar de modo normal a articulação ignorando silenciosamente a desproporção entre os acontecimentos conectados. A ligação causal entre a necessidade de Zeno conseguir mais cigarros e a quantidade maior recebida pelo irmão ainda pode ser considerada como uma explicação satisfatória na medida em que a competição entre irmãos é um dado culturalmente disseminado; no entanto, a próxima ligação causal, na qual é sugerido que a necessidade de superar o irmão é tal que seria suficiente para impelir o protagonista ao roubo, é desproporcional a ponto de não poder ser assegurada por elementos culturais que pudessem ser dispensados de explicitação. Apesar disso, a narrativa não a coloca em questão nem lhe dá um desenvolvimento hermenêutico; ela simplesmente não diferencia as duas conexões, reservando o mesmo tratamento a ambas.

Além disso, a conexão em análise parece estar amparada na causalidade virtual da sequência narrativa, que expusemos no primeiro capítulo. De fato, a confusão entre a causalidade e a sucessão narrativa favorece que o narrador simplesmente assuma e apresente diretamente a necessidade de não ser superado na quantidade de cigarros pelo irmão como causa para roubar o pai - justamente o próximo trecho da história de Zeno a ser relatado -, desprezando, por mais superficiais que pudessem ser, quaisquer investigações para confirmar essa relação causal e quaisquer argumentações para expôla. Num contexto de generalizada debilidade em termos causais, o recurso a tal procedimento é bastante discreto e eficiente em despistar as carências de causalidade nas transições narrativas.

Encerremos a presente análise, pois consideramos que ela já foi suficientemente desenvolvida no sentido de expor a importância que a tendência a apresentar causas, ainda que costumem se revelar insubsistentes, possui na autobiografia

\footnotetext{
${ }^{50}$ Parece que Giuseppe ganhava muito dinheiro do pai e nos presenteava com aqueles cigarros. Tenho certeza, porém, de que os oferecia mais a meu irmão do que a mim. Vem daí a necessidade que enfrentei para conseguir outros por conta própria. Sucedeu, portanto, que passei a roubar (2006, p. 15-16).
} 
de Zeno, tanto ao recuperarmos o apelo à causalidade que ainda persiste no recurso à superstição ou ao destino quanto ao explicitarmos algumas formas pelas quais são constituídas as relações que Zeno insiste em operar como se fossem efetivamente causais.

Por fim, analisemos o tratamento dado às expectativas partindo do que estudamos previamente neste capítulo. Trabalhando com dois modelos fortemente articulados de expectativas, o código hermenêutico e o caminho de vida do burguês, os resultados que obtivemos inicialmente foram: na primeira seção, argumentamos que o narrador recusava sistematicamente a convenção literária do código hermenêutico por meio da prolepse de algum fato crucial em cada capítulo da autobiografia; ao passo que, na primeira etapa da presente seção, constatamos em grande medida a conformidade da organização global dos capítulos da autobiografia com o modelo social da vida burguesa.

Comecemos observando que a prolepse de recusa ao código hermenêutico não deixa o futuro do protagonista jogado ao acaso; pelo contrário, ela confirma dentro de cada capítulo a expectativa concernente à vida burguesa, ainda que o resultado antecipado possa ser a sua frustração, como nos casos da incapacidade de casar com Ada ou do fracasso da empresa na qual trabalha com Guido - afinal, resultados negativos não são uma recusa de um modelo de expectativas.

A recusa do código hermenêutico não exige o abandono completo das expectativas, pois, ao mesmo tempo que o fato crucial do capítulo deixa de ser desenvolvido como expectativa por ser antecipado, uma nova expectativa se impõe, a de como esse final será alcançado, dando origem a um campo de expectativas interno à prolepse global do capítulo.

As expectativas internas à prolepse tampouco recebem codificação hermenêutica do narrador, mas há uma mudança no que tange ao modelo social da vida burguesa. Ainda que o resultado antecipado esteja aderente ao modelo, algumas situações importantes pelas quais Zeno passa ao longo do capítulo são incompatíveis com ele. Como exemplo, usemos o sexto capítulo, para o qual podemos citar como atos de Zeno que são estranhos a uma vida burguesa: o tratamento rude dispensado à amante dócil, o qual é especialmente tematizado na parte na qual estão os primeiros encontros com ela (2004, p. 818-870), a manutenção do professor de canto quando se declara para a aluna (2004, p. 883-885) e a anuência ao desejo de Carla de encontrar a sua esposa (2004, p. 889-890). Tais ações do protagonista o afastam da ordem burguesa e frustram 
as expectativas correspondentes, como se a relação formulada por Bakhtin fosse invertida nos segmentos inferiores aos capítulos, dado que seria o tempo biográfico "real" que dissolveria o tempo ideal do modelo social que Zeno, como protagonista e narrador, supostamente adota.

Assim, tanto as ações de Zeno quanto a sua escrita não aderem a modelos fortemente articulados de expectativas bastante comuns na época histórica referida pelos tempos da narração e da história, mas isso não impede que a narrativa continue a gerar expectativas que se organizam de duas maneiras conflitantes: no âmbito dos capítulos em geral e de cada um deles, elas tendem a aderir ao modelo da vida burguesa; no desenvolvimento interno de cada capítulo, surgem desvios a tal modelo num grau suficiente para que tal adesão malogre nesse âmbito mais restrito.

Com base nos resultados que já obtivemos neste capítulo, concluamos a segunda etapa da presente seção considerando que a autobiografia de Zeno dá dois tratamentos conflitantes à temporalidade linear. Por um lado, ela não é ostensivamente negada; pelo contrário, argumentamos que ela é uma das suas temporalidades cruciais na medida em que a autobiografia se constitui sistematicamente de modo que a cronologia predomina, a apresentação de causas prolifera, e um modelo linear e fortemente articulado como a vida burguesa fornece as expectativas sobre a vida do protagonista. A sua adoção é particularmente bem sucedida no nível máximo de segmentação proposto pela narrativa, o dos capítulos, que seguem em grande medida a cronologia da história e cuja divisão é feita, com exceção do capítulo sobre o vício de fumar, segundo o modelo da vida burguesa, o que garante o controle de expectativas sobre cada etapa do modelo e o encadeamento causal entre as etapas.

Por outro lado, consideramos que o texto autobiográfico de Zeno não fornece uma sustentação efetiva para a temporalidade linear, a qual nunca se estabelece para além da mera aparência. De fato, ela está constantemente não só sendo proposta, mas também fracassando: os desvios cronológicos são recorrentes; a condução das expectativas malogra no âmbito interno dos capítulos, tanto por não ser elaborada segundo o código hermenêutico quanto pelo comportamento do protagonista se afastar recorrentemente do modelo burguês; proliferam as lacunas causais, ainda que sejam quase sempre silenciadas; e, a mais sintética expressão do conflito em análise, as causas apresentadas geralmente se revelam insubsistentes.

As falhas no encadeamento causal fazem com que um acontecimento seja narrado sem que sejam efetivamente identificados os acontecimentos passados que o 
causaram, e as falhas na codificação hermenêutica fazem com que um acontecimento seja narrado sem que os acontecimentos vindouros sejam antecipados na condição de expectativas, ainda que o desenlace principal de cada capítulo seja informado com muita antecedência. Em suma, a narrativa geralmente progride sem que haja a apresentação das causas principais do acontecimento narrado nem a sugestão dos principais efeitos que ele tende a causar. O baixo nível das conexões causais com os eventos passados e das projeções por expectativa dos eventos futuros provoca a impressão geral de uma mera sucessão de fatos ou que eles se sucedam casualmente, e isso caracteriza o que denominamos como temporalidade de onda devido à caracterização da onda do mar como mera mudança incessante num trecho que comentaremos na próxima seção.

Usando a denominação que apresentamos no parágrafo anterior, reformulemos assim a conclusão da segunda etapa desta seção: a autobiografia de Zeno é constituída pelo embate entre as temporalidades linear e de onda.

Por fim, reservamos a terceira etapa da presente seção à breve tarefa de derivar duas alternativas de configurações temporais para o embate entre temporalidades com o qual encerramos a etapa anterior. A primeira configuração temporal é própria a Zeno e se define pelo confronto entre as temporalidades linear e de onda jamais ser resolvido. Por um lado, seja como protagonista, seja como narrador, Zeno não propõe nada que recupere retrospectivamente as deficiências da temporalidade linear que assinalamos; por exemplo, ele não nos apresenta uma explicação que nos permitisse reconstituir a cadeia causal do seu comportamento nos tempos da história e da narração. É contundente o contraste de tal construção com o da principal obra do escritor Marcel Proust, na qual o protagonista finalmente compreende como reencontrar o tempo perdido; como comenta o crítico Guido Guglielmi, no que se refere à incapacidade de Zeno para oferecer uma síntese que finalmente estabelecerá retrospectivamente a ordem causal da autobiografia:

[...] la differenza con il modello proustiano si rivela massima. La Recherche è una totalità labirintica ma chiusa, in cui frammenti di mondo sono depositati e custoditi per sempre. [...] L'opera è perfettamente autosufficiente: nessun evento può più turbala. Il presente è il presente assoluto della scrittura, non più suscettibile di trasformazioni. (1986, p. 40)

Por outro lado, Zeno não desiste da temporalidade linear nem conclui que ela fracassou apesar dos insistentes desvios; simplesmente continua a tentar adotá-la até o fim da autobiografia, ainda que os resultados das tentativas sejam sempre incapazes de 
superar o embate com a temporalidade de onda. Enfim, a configuração temporal que resulta da experiência manifestada por Zeno é a da manutenção indeterminada do embate em análise.

A segunda configuração temporal surge quando abandonamos o ponto de vista de Zeno sobre o embate entre as temporalidades linear e de onda, pois a acumulação de falhas da primeira torna plausível que a autobiografia proporcione a experiência alternativa de que o embate atinge um resultado, o do contínuo fracasso da temporalidade linear frente à de onda.

Assim, a segunda configuração consiste propriamente em dois momentos, um negativo e outro positivo. Há um momento negativo porque não é que a autobiografia simplesmente não esteja articulada segundo a temporalidade linear; na presente seção, justamente insistimos nas tentativas feitas para adotá-la, mas o resultado efetivo de tal empenho é o fracasso em impor essa temporalidade ao texto. A partir do fracasso da articulação linear do tempo, nos deparamos com o momento positivo da afirmação da temporalidade de onda, que nesse caso se torna aquela efetivamente estabelecida pela autobiografia.

\subsection{A superação do âmbito da temporalidade manifestada por Zeno: uma introdução}

No capítulo anterior, a nossa análise expôs enfaticamente a importância crucial que atribuímos às temporalidades da repetição do recalcado e, como consequência imediata dessa, da nota única na diegese dos textos narrados por Zeno. Na seção anterior, tratamos de configurações temporais que, a princípio, independem das temporalidades que abordamos no segundo capítulo. O nosso objetivo na presente seção é começar a articular esses dois grupos de resultados a fim de propor uma síntese das configurações temporais do romance que vigoram ao longo dos dois capítulos iniciais e da autobiografia.

Comecemos observando que um dos resultados que obtivemos na seção anterior foi uma configuração temporal da autobiografia de Zeno que extrapola aquela da experiência imediata do seu protagonista e narrador, ainda que ambas estivessem 
extremamente conectadas por se originarem do mesmo embate entre as temporalidades linear e de onda. Ora, tal movimento da nossa análise prévia nos induz a questionar se o romance autorizaria que prosseguíssemos no sentido de superar a temporalidade manifestada por Zeno, de modo que até mesmo o embate que a constitui se subordinaria a outras temporalidades vigentes no texto. Com o intuito de responder essa pergunta, dedicaremos esta seção a examinar as seguintes partes do romance: o prefácio, o preâmbulo e o começo do quinto capítulo.

A inclusão do prefácio fictício provoca uma radical inversão cronológica, pois, tal como ocorre com os prefácios reais, ele é colocado antes do texto propriamente dito - como primeiro capítulo do romance - e foi escrito após o mesmo. Além disso, introduz uma voz narrativa que não volta a aparecer, a do doutor S., que assina o prefácio. A fim de compreender melhor essa inversão e a única ocorrência dessa voz, iniciemos o nosso estudo pelo trecho que apresenta o conflito acerca dos motivos para a própria existência do texto prefaciado:

\begin{abstract}
Debbo scusarmi di aver indotto il mio paziente a scrivere la sua autobiografia; gli studiosi di psico-analisi arriccerranno il naso a tanta novità. Ma egli era vecchio ed io sperai che in tale rievocazione il suo passato si rinverdisse, che l'autobiografia fosse un buon preludio alla psico-analisi. Oggi ancora la mia idea mi pare buona perché mi ha dato dei risultati insperati, che sarebbero stati maggiori se il malato sul più bello non si fosse sottratto alla cura truffandomi del frutto della mia lunga paziente analisi di queste memorie. ${ }^{51}(2004$, p. 625)
\end{abstract}

Em termos dos dados antecipados sobre o que será narrado, somos apresentados à história baseada no tratamento de um paciente por um psicanalista e da qual se esboçam cinco fases: a vida do paciente, que é narrada por ele próprio; a consulta prévia (supostamente única) ao tratamento; a autobiografia, que serve de prelúdio à terapia; o tratamento; a fase posterior ao abandono da terapia, na qual o prefácio é escrito. Somos informados apenas de que a primeira e a terceira fases são tratadas no livro, de modo que as três fases restantes parecem estar restritas ao prefácio. Só no último capítulo os leitores saberão que o livro também trata das duas fases finais. Em suma, o prefácio nos antecipa que leremos uma autobiografia preparatória a uma terapia psicanalítica e, quanto ao resto, nos faz crer que seria a única fonte de

\footnotetext{
${ }^{51}$ Devo escusar-me por haver induzido meu paciente a escrever sua autobiografia; os estudiosos de psicanálise torcerão o nariz a tamanha novidade. Mas ele era velho, e eu supunha que com tal evocação o seu passado si reflorisse e que a autobiografia se mostrasse um bom prelúdio ao tratamento. Até hoje a ideia me parece boa, pois forneceu-me resultados inesperados, os quais teriam sido ainda melhores se o paciente, no momento crítico, não se tivesse subtraído à cura, furtando-me assim os frutos da longa e paciente análise destas memórias (2006, p. 11).
} 
informação.

Os dados mencionados no parágrafo anterior já são suficientes para sugerir um resultado de extrema importância: o prefácio do doutor S. é a única parte do texto cujo escritor ficcional não é o paciente. O que é confirmado mesmo no caso do último capítulo, um diário que Zeno escreve após abandonar a terapia, sobre o qual o prefácio não faz nenhuma menção. A grande relevância de a narração posterior ser exclusiva do paciente é enfatizada pela acusação da sua inveracidade no final do prefácio: "Se sapesse quante sorprese potrebbero risultargli dal commento delle tante verità e bugie ch'egli ha qui accumulate!"52 (2004, p. 625). Não nos deteremos na análise da falta de confiabilidade do narrador, tão bem elaborada por Lavagetto, conforme já mencionamos no primeiro capítulo. Destacaremos apenas que o prefácio elabora a falta de confiabilidade por meio de conceitos psicanalíticos e o faz não só para Zeno, mas também para o doutor $\mathrm{S}$.

De fato, o prefácio inicia aludindo ao conceito de transferência: "Io sono il dottore di cui in questa novella si parla talvolta con parole poco lusinghiere. Chi di psicoanalisi s'intende, sa dove piazzare l'antipatia che il paziente mi dedica"53 (2004, p. 625). Ao insinuar a razão da antipatia de Zeno, o psicanalista introduz "l'idea del transfert, il meccanismo con cui il paziente traspone sull'analista sentimenti ed emozioni che ha provato in passato nei riguardi di persone importanti della sua infanzia" (MOLONEY, 1998, p. 86). Simetricamente, o prefácio também trata da contratransferência, a transposição que o analista faz de tais sentimentos e emoções para o paciente, uma vez que o doutor S. "ci rivela anche senza volerlo che ha avuto luogo anche il controtransfert" (MOLONEY, 1998, p. 88) no último parágrafo: "Le pubblico per vendetta e spero gli dispiaccia. Sappia però ch'io sono pronto di dividere con lui i lauti onorarii che ricaverò da questa pubblicazione a patto egli riprenda la cura"54 (2004, p. 625). Ou seja, a publicação do livro serve para que o psicanalista, de modo premeditado, busque se vingar do paciente, quebre o sigilo sobre as suas informações pessoais e ainda tente comprar o seu retorno ao tratamento! É claro que semelhante relação com o paciente é inaceitável para qualquer médico; na verdade, o exagero

\footnotetext{
${ }^{52}$ Se soubesse quantas surpresas poderiam resultar do comentário de todas as verdades e mentiras que ele aqui acumulou (2006, p. 11)!...

${ }^{53}$ Sou o médico de quem às vezes se fala neste romance com palavras pouco lisonjeiras. Quem entende de psicanálise sabe como interpretar a antipatia que o paciente me dedica (2006, p. 11).

${ }^{54}$ Publico-as por vingança e espero que o autor se aborreça. Seja dito, porém, que estou pronto a dividir com ele os direitos autorais desta publicação, desde que ele reinicie o tratamento (2006, p. 11).
} 
cômico com o qual é apresentada garante que a credibilidade profissional do doutor S. seja comprometida mesmo para os leitores que desconhecem o conceito de contratransferência.

Enfim, as dificuldades expostas pelo prefácio extrapolam as mais comuns de um narrador que não inspira confiança no sentido de implicar também as questões próprias a um paciente psicanalítico. $\mathrm{Na}$ verdade, a situação colocada pelo prefácio é ainda mais complexa, pois não se trata da prática clínica ortodoxamente conduzida pelos psicanalistas: como é afirmado na primeira citação que fizemos do prefácio, eles rejeitariam a ousada inovação de uma autobiografia. Logo, o romance propõe uma situação para o qual nem os psicanalistas seriam diretamente treinados.

Consideramos que a extrema dificuldade que expusemos no parágrafo anterior é enfatizada pelo fato de que o psicanalista parece só se dirigir aos leitores para abandoná-los, pois, como não anuncia o relato do tratamento e do que ocorre depois dele, eles não esperam conhecer o parecer clínico que formou a respeito de Zeno. Eles podem mesmo duvidar que ele haja formado algum, já que o paciente abandonou a terapia. Além disso, mesmo quando forem surpreendidos, no último capítulo, com tal parecer e os comentários do doutor S. sobre a autobiografia, o prefácio novamente garante, como já comentamos, que eles não poderão contar com a credibilidade profissional do psicanalista.

Em suma, concluímos que, no romance em análise, o principal aspecto temporal de um prefácio fictício - a radical inversão cronológica de preceder o texto propriamente dito de uma escrita que lhe é posterior - se deve à necessidade de antecipar para os leitores as dificuldades que o texto lhes impõe desde as primeiras frases de Zeno pela falta de confiabilidade do narrador, a qual é agravada por questões originadas pelo contexto psicanalítico do enredo, seja a transferência intrínseca à relação entre o psicanalista e o paciente, seja o procedimento heterodoxo da autobiografia. Concluímos também que se pretende sugerir - como se a alusão às dificuldades mencionadas não fosse suficiente - que os leitores não terão auxílio para dirimi-las da parte de um personagem psicanaliticamente instruído como o doutor S., pois as poucas frases que lhe competem no romance são o bastante para lhe retirar a credibilidade profissional pela contratransferência comicamente exagerada e para realçar a sua precipitada saída do texto sem anúncio concreto de retorno.

Uma vez que analisamos o prefácio, examinemos o preâmbulo, o capítulo que precede a escrita da autobiografia, que se estende do terceiro ao penúltimo capítulos. 
Assim, há uma parte prévia à autobiografia propriamente dita, por meio da qual o narrador registra brevemente a sua preparação para essa tarefa e as primeiras tentativas frustradas de realizá-la. Além do preâmbulo, a parte prévia continua nos quatro primeiros parágrafos do terceiro capítulo.

Longe da simplória concepção de que a autobiografia seria uma mera exposição das vivências do passado, somos confrontados com uma incisiva exploração de conexões temporais envolvendo tanto o presente quanto o passado transcorrido desde o momento que se pretende narrar. Uma boa amostra disso já está presente no parágrafo inicial do preâmbulo: "Vedere la mia infanzia? Più di dieci lustri me ne separano e i miei occhi presbiti forse potrebbero arrivarci se la luce che ancora ne riverbera non fosse tagliata da ostacoli d'ogni genere, vere alte montagne: i miei anni e qualche mia ora"55 (2004, p. 626). A recordação da infância é um problema não só por causa das décadas que a separam do momento no qual Zeno escreve, mas também é afetada pelo momento atual em si mesmo, como podemos deduzir da referência tanto aos olhos cansados de Zeno quanto às horas que antecedem o ato de lembrar. Ademais, essas horas são uma influência de tal importância a ponto de serem qualificadas de altas montanhas e colocadas em pé de igualdade com as dezenas de anos já vividos, que, por sua vez, não são uma mera redundância do grande intervalo temporal (os dez lustros) mencionado, pois o pronome possessivo "miei” os diferencia a fim de expressar que são as vivências de Zeno nesse tempo que importam. Logo, às dificuldades expostas pelo prefácio para abordar a autobiografia em questão, devemos acrescentar as interferências de outros tempos na narrativa de cada momento determinado.

Em seguida, há uma retomada da consulta inicial que desenvolve a importância do tempo da narração e a reação de Zeno à recomendação médica:

Il dottore mi raccomandò di non ostinarmi a guardare tanto lontano. Anche le cose recenti sono preziose per essi e sopra tutto le immaginazioni e i sogni della notte prima. Ma un po' d'ordine pur dovrebb'esserci e per poter cominciare $a b$ ovo, appena abbandonato il dottore [...], solo per facilitargli il compito, comperai e lessi un trattato di psicoanalisi. ${ }^{56}$ (2004, p. 626)

Nesse segundo parágrafo, a recomendação do doutor S. se baseia na concepção

\footnotetext{
${ }^{55}$ Rever a minha infância? Já lá se vão mais de dez lustros, mas minha vista cansada talvez pudesse ver a luz que dela ainda dimana, não fosse a interposição de obstáculos de toda espécie, verdadeiras montanhas: todos esses anos e algumas horas de minha vida (2006, p. 13).

${ }^{56} \mathrm{O}$ doutor recomendou-me que não me obstinasse em perscrutar longe demais. Os fatos recentes são igualmente preciosos, sobretudo as imagens e os sonhos da noite anterior. Mas é preciso estabelecer uma certa ordem para poder começar ab ovo. Mal deixei o consultório do médico [...], corri a comprar um compêndio de psicanálise e li-o no intuito de facilitar-me a tarefa (2006, p. 13).
} 
psicanalítica de que os conteúdos recalcados continuam a interferir no presente por meio das associações livres de ideias, um elemento fundamental da psicanálise pelo qual são produzidos materiais que escapam ao controle consciente. Trata-se de outra via para o conhecimento do sujeito, pela qual ele seria alcançado por intermédio de ocorrências no tempo presente, principalmente de eventos mentais nos quais o controle consciente é reduzido, facilitando a ocorrência de tais associações livres. A isso se segue uma mudança supreendente de rumo, para a qual os leitores já deveriam se acautelar conforme o aviso feito no prefácio sobre as mentiras de Zeno. Como bem comenta a estudiosa Beatrice Stasi:

Mentre il medico ha coscienziosamente suggerito al suo paziente di non cercare d'impremere una determinata direzione al suo sforzo di memoria, costui dichiara subito un'intenzione di mettere ordine nei suoi recordi che rivela una volontà di controllo razionale sui ricordi decisamente in contrasto con l'atteggiamento di abbandono prescritto dalla terapia psicanalitica [...]. Di male in peggio: non solo Zeno programma di organizzare la sua rievocazione autobiografica in maniera assolutamente consapevole, [...] ma per giunta confessa candidamente di aver comprato e letto un trattato di psicanalisi. Altro che abbandono! Il paziente vuole essere in grado di controllare non solo le proprie parole, ma anche il modo in cui il medico interpretarà quelle parole, impossessandosi preventivamente del codice in base al quale saranno decifrate. (2009, p. 102-103)

Consideramos que os aspectos temporais da exigência de ordem são ressaltados ao ganhar a formulação de um começo $a b$ ovo, de modo que ela parece ser pensada em termos do tempo da história da sua autobiografia, seja porque esse era o contexto principal do preâmbulo até então, seja porque geralmente se espera que a vida de uma pessoa seja contada desde o nascimento; no entanto, uma nova surpresa é produzida ao se verificar que a origem exigida se refere ao tempo da narração e ao doutor S., o que também assinala que Zeno já se prepara para a fase do tratamento. Ainda que não sejam explicitadas as consequências, a leitura do tratado de psicanálise introduz mais uma dificuldade para lidar com a autobiografia de Zeno e leva ao ápice a gradação que os dois parágrafos iniciais operam em relação à importância do presente daquele que recorda e narra para o que é recordado e narrado: as meras alusões das reflexões de Zeno no primeiro parágrafo são seguidas pela referência direta na recomendação médica e finalmente pela realização concreta que se dá nessa inesperada leitura. Ainda neste capítulo trataremos das interferências provocadas ao longo do livro pelo conhecimento psicanalítico que o narrador adquire com o tratado lido.

Comentada a valorização do presente do narrador que reconhecemos nos dois parágrafos iniciais do preâmbulo, verifiquemos como o restante dele e os primeiros 
parágrafos do capítulo seguinte expõem como o conflito entre os principais elementos do tempo da narração - o tratamento, no qual é recomendado que Zeno assuma uma atitude de entrega, e a autobiografia - impede o início do relato e determina a rejeição da valorização do tempo da narração. Esse conflito ganha uma correlação objetiva por meio da oposição entre a poltrona e o lápis:

Dopo pranzato, sdraiato comodamente su una poltrona Club, ho la matita e un pezzo di carta in mano. La mia fronte è spianata perché dalla mia mente eliminai ogni sforzo. Il mio pensiero mi appare isolato da me. Io lo vedo. S'alza, s'abbassa... ma è la sua sola attività. Per ricordargli ch'esso è il pensiero e che sarebbe suo compito di manifestarsi, afferro la matita. Ecco che la mia fronte si corruga perché ogni parola è composta di tante lettere e il presente imperioso risorge ed offusca il passato. Ieri avevo tentato il massimo abbandono. L'esperimento finí nel sonno più profondo [...]

Mercé la matita che ho in mano, resto desto, oggi. Vedo, intravvedo delle immagini bizzarre che non possono avere nessuna relazione col mio passato: una locomotiva che sbuffa su una salita trascinando delle innumerevoli vetture; chissà donde venga e dove vada e perché sia ora capitata qui! ${ }^{57}$ (2004, p. 626-627)

Quanto à função desempenhada pelo lápis, adotamos o comentário de Stasi:

Strumento di scrittura, e dunque di un'attività intellettuale che richiede
concentrazione, la matita, prima ancora di essere usata, impone a Zeno il
pensiero dell'atto compositivo che sta per compiere, sovrapponendo così
nella sua coscienza l'impegno presente - la sua programmazione ed
esecuzione - ai ricordi inseguiti del passato. Ancora una volta, dunque, il
Preambolo illumina l'intima contraddizione che vizia all'origine il tentativo
di recupero memoriale di Zeno: una consapevole attenzione alla scrittura che
prende il sopravvento sull'abbandono tendenzialmente incosciente al flusso
di ricordi. (2009, p. 103-104)

A poltrona, por sua vez, é o local privilegiado para assumir uma atitude de entrega e é explicitamente abandonada no início do próximo capítulo, no qual Zeno efetivamente começa a sua autobiografia: "Credo che del fumo posso scrivere qui al mio tavolo senz'andar a sognare su quella poltrona"58 (2004, p. 628). Ao abandoná-la, também renuncia à postura psicanalítica representada por ela e, portanto, a incentivar que o seu inconsciente se manifeste, como é sucintamente conotado pelo verbo

\footnotetext{
57 Depois do almoço, comodamente esparramado numa poltrona de braços, eis-me de lápis e papel na mão. Tenho a fronte completamente descontraída, pois eliminei da mente todo e qualquer esforço. Meu pensamento parece dissociado de mim. Chego a vêlo. Ergue-se, torna a baixar... e esta é sua única atividade. Para recordar-lhe que é meu pensamento e que tem por obrigação manifestar-se, empunho o lápis. Eis que minha fronte se enruga ao pensar nas palavras que são compostas de tantas letras. $\mathrm{O}$ presente imperioso ressurge e ofusca o passado. Ontem tentei um abandono total. A experiência terminou no sono mais profundo [...] Graças ao lápis que hoje trago à mão, mantenho-me desperto. Vejo, entrevejo imagens bizarras que não podem ter qualquer relação com meu passado: uma locomotiva que resfolega pela encosta acima a arrastar inúmeros vagões; sabe-se lá de onde vem e para onde vai e o que estará fazendo nestas recordações (2006, p. 13-14)?!

58 Acredito, inclusive, que a respeito do fumo posso escrever aqui mesmo, à minha mesa, sem necessidade de ir sonhar ali naquela poltrona (2006, p. 15).
} 
"sonhar", dado que os sonhos são a mais intensa manifestação do inconsciente descoberta pela psicanálise em pessoas livres das psicopatologias. A poltrona é substituída pela mesa, de modo que o narrador agora se apresenta "nell'atteggiamento classico e controllato dello scrittore" (STASI, 2009, p. 110). Zeno, ao recordar as caixas nas quais se vendiam os primeiros cigarros que fumou, ainda retornará uma última vez à poltrona, aparentemente conseguindo um acesso ao seu inconsciente, mas reagindo de uma maneira nada promissora:

Ecco: attorno a una di quelle scatole s'aggruppano subito varie persone con qualche loro tratto, sufficiente per suggerirmene il nome, non bastevole però a commovermi per l'impensato incontro. Tento di ottenere di più e vado alla poltrona: le persone sbiadiscono e al loro posto si mettono dei buffoni che mi deridono. Ritorno sconfortato al tavolo..$^{59}(2004$, p. 628)

Notemos que, das tentativas fracassadas de iniciar a narração, apenas as duas primeiras ainda eram realmente incipientes e provavelmente não poderiam ser melhor aproveitadas. A imagem da locomotiva que surge na terceira tentativa valeria ser investigada psicanalicamente mesmo sem trazer uma relação manifesta com o passado de Zeno, e a última tentativa é sumariamente interrompida quando ele sente desconforto ao imaginar que está sendo escarnecido, o que é um sinal incisivo de que não quer se confrontar com sentimentos desagradáveis. Enfim, não será o paciente que estimulará expressões mais manifestas do seu inconsciente, e o rumo da autobiografia é decidido: "Il riso bufonesco sembra liquidare la praticabilità dell'approccio alla memoria suggerito dal dottore, determinando il ritorno definitivo al tavolo e al controllo razionale del racconto" (STASI, 2009, p. 111).

Concluímos que a parte prévia à autobiografia, iniciada no preâmbulo e encerrada nos primeiros parágrafos do terceiro capítulo, rejeita os procedimentos clínicos com os quais o psicanalista opera, confirmando o anúncio feito no prefácio. Obviamente, isso inclui a rejeição da temporalidade clínica da psicanálise, o que significa recusar a valorização do tempo da narração, no qual surgiriam os eventos mentais a partir dos quais se tentaria identificar os rastros do passado. Também significa recusar a ordem na qual Freud esperava que esses rastros fossem obtidos na clínica psicanalítica: conforme já comentamos no primeiro capítulo, ele constatou que a recordação dos momentos recalcados ocorre segundo uma temporalidade

\footnotetext{
${ }^{59}$ Aí está: em volta de uma dessas caixas agrupamse de repente várias pessoas, mostrando um ou outro traço fisionômico, suficientes para sugerir-lhes o nome mas não tanto para deixar-me comovido pelo inesperado do encontro. Procuro buscar mais e vou para a poltrona: as pessoas esfumam-se, dando lugar a indivíduos cômicos, que escarnecem de mim. Com desconforto, retorno à mesa (2006, p. 15).
} 
cronologicamente invertida. $\mathrm{O}$ preâmbulo fornece o que seria a primeira recordação dessa cadeia que avança para o passado (caso Zeno não rejeitasse o estado de entrega), mas os leitores só terão condições de saber isso no quarto capítulo, quando o narrador descobrir que a locomotiva remete ao pai moribundo:

[...] scopro che l'immagine che m'ossessionò al primo mio tentativo di vedere nel mio passato, quella locomotiva che trascina una sequela di vagoni su per un'erta, io l'ebbi per la prima volta ascoltando da quel sofà il respiro di mio padre. Vanno cosí le locomotive che trascinano dei pesi enormi: emettono degli sbuffi regolari che poi s'accelerano e finiscono in una sosta, anche quella una sosta minacciosa perché chi ascolta può temere di veder finire la macchina e il suo traino a precipizio a valle. Davvero! Il mio primo sforzo di ricordare, m'aveva riportato a quella notte, alle ore più importanti della mia vita. ${ }^{60}(2004$, p. 669$)$

Comentaremos, ainda no presente capítulo, essa descoberta que a narrativa de Zeno faz do momento passado a que aludia a imagem da locomotiva. Por ora, observemos que, rejeitada na preparação para a autobiografia, a temporalidade invertida das recordações só ocorrerá quando Zeno efetivamente estiver em tratamento com o psicanalista. Então, como é relatado no diário, terá a sequência de visões que evocam a infância: as duas primeiras com o irmão, sobre as quais o próprio narrador diz que a segunda (2004, p. 1053) é muito anterior à primeira (2004, p. 1051-1052); a terceira (2004, p. 1054) só com os pais, como se o irmão ainda nem fosse nascido; a quarta (2004, p. 1055) só com a mãe, que é entendida como tudo para a criança, o que remete a uma fase ainda anterior da infância.

Interrompamos a análise do preâmbulo para elaborar uma síntese dos resultados que obtivemos do estudo do início do romance até os primeiros parágrafos do terceiro capítulo. Consideramos que a credibilidade da autobiografia de Zeno é questionada insistentemente pelo alerta direto às mentiras do narrador, pela alusão à dificuldade da interferência de outros tempos da vida de Zeno ao relatar um momento determinado e pelas complicações psicanalíticas para a confiabilidade do narrador, como a transferência, a leitura do tratado de psicanálise logo após a consulta com o doutor S. e a heterodoxia clínica da própria autobiografia, a qual ainda é agravada pela sua recusa a seguir a orientação médica de valorizar o tempo presente, principalmente

\footnotetext{
${ }^{60}[\ldots]$ descubro que a imagem que me obcecou desde a primeira tentativa de perscrutar o passado, a locomotiva que arrasta uma série de vagões ladeira acima, surgiu em meu espírito, ouvindo daquele sofá a respiração de meu pai. É exatamente assim que fazem as locomotivas que arrastam pesos enormes: emitem baforadas regulares, que depois aceleram para terminar numa parada, também esta perigosa, porque quem a ouve teme que a máquina e seus vagões se precipitem morro abaixo. Curioso! Meu primeiro esforço para evocar o passado conduziu-me precisamente àquela noite, às horas mais importantes da minha vida (2006, p. 53).
} 
no caso dos eventos mentais menos conscientes. Com base na concentração de tantos questionamentos contundentes em pouco mais de uma dúzia de parágrafos, retomemos a pergunta que fizemos sobre a superação da temporalidade manifestada por Zeno. Por um lado, a desconfiança resultante sobre a credibilidade do narrador nos incentiva amplamente a adotarmos abordagens para a narrativa que se distanciem daquela adotada por Zeno. Por outro lado, a credibilidade da autobiografia é tão questionada que coloca em dúvida se o seu texto fornece elementos suficientes para que consigamos propor uma abordagem capaz de superar as próprias dificuldades que nos induzem à desconfiança da narrativa.

Finalizemos a nossa análise do preâmbulo justamente argumentando que ele termina, ao tratar da suposta recordação de um bebê, fornecendo indícios a favor da adoção de uma abordagem que supere a do próprio Zeno, pois alerta os leitores para o fato de o narrador recusar que a busca do passado parta do presente não impede que essa relação entre os dois tempos apareça indireta e involuntariamente:

Nel dormiveglia ricordo che il mio testo asserisce che con questo sistema si può arrivar a ricordare la prima infanzia, quella in fasce. Subito vedo un bambino in fasce, ma perché dovrei essere io quello? Non mi somiglia affatto e credo sia invece quello nato poche settimane or sono a mia cognata [...]. Povero bambino! Altro che ricordare la mia infanzia! Io non trovo neppure la via di avvisare te, che vivi ora la tua, dell'importanza di ricordarla a vantaggio della tua intelligenza e della tua salute. Quando arriverai a sapere che sarebbe bene tu sapessi mandare a mente la tua vita, anche quella tanta parte di essa che ti ripugnerà? $\mathrm{E}$ intanto, inconscio, vai investigando il tuo piccolo organismo alla ricerca del piacere e le tue scoperte deliziose ti avvieranno al dolore e alla malattia cui sarai spinto anche da coloro che non lo vorrebbero. Come fare? È impossibile tutelare la tua culla. Nel tuo seno fantolino! - si va facendo una combinazione misteriosa. Ogni minuto che passa vi getta un reagente. Troppe probabilità di malattia vi sono per te, perché non tutti i tuoi minuti possono essere puri. Eppoi - fantolino! - sei consanguineo di persone ch'io conosco. I minuti che passano ora possono anche essere puri, ma, certo, tali non furono tutti i secoli che ti prepararono. ${ }^{61}$ (2004, p. 627)

\footnotetext{
${ }^{61} \mathrm{Na}$ minha sonolência, recordo que o compêndio assegurava, por este sistema, ser possível recordarmos a primeira infância, a dos cueiros. De repente, vejo uma criança de fraldas, mas por que tem de ser eu? Não se parece nada comigo; na verdade, acho que se trata do bebê de minha cunhada, nascido há poucas semanas [...]. Pobre criança! Ainda bem que se trata de recordar a minha infância! Não saberia encontrar um jeito de te aconselhar, agora que vives a tua, sobre a importância de recordá-la para o bem de tua inteligência e de tua saúde. Quando chegarás a saber que seria bom se pudesses reter na memória a tua vida, até mesmo as partes que te possam repugnar? E, no entanto, inconsciente, vais investigando o teu pequeno organismo à procura do prazer, $\mathrm{e}$ as tuas deliciosas descobertas te levarão à dolore e à doença, para as quais contribuirão até mesmo aqueles que mais te querem. Que fazer? É impossível tutelar teu berço. No teu seio - pequerrucho! - se vai processando uma combinação misteriosa. Cada minuto que passa, lança-lhe um reagente. Há demasiadas possibilidades de doenças para ti, porque não é possível que sejam puros todos esses minutos. E além disso - pequerrucho! - és consanguíneo de pessoas que conheço. Os minutos que agora passam até que podiam ser puros, mas tal não foram decerto os séculos que te prepararam (2006, p. 14).
} 
O começo da citação parece bem desfavorável, pois o trecho parte do tratado de psicanálise, o que indicaria uma disposição nada espontânea. De fato, Zeno nega mais uma vez que haja recordado o seu passado remoto e sugere que seria necessário advertir o bebê sobre a importância de memorizar o que está vivendo, mas, como isso é impossível, questiona quando ele saberá isso. Se acabasse nessa pergunta, o parágrafo seria apenas mais um exemplo do que já havíamos examinado, mas Zeno continua escrevendo sobre o bebê: a sua busca pelo prazer; a relação entre o prazer buscado e a doença; e a função dos familiares nessa relação. Também aproveita para acusar a impureza de parentes. Todas essas declarações feitas no presente da escrita provavelmente são reveladoras sobre o passado de quem as fez, mas nos concentremos no que foi escrito sobre o bebê da cunhada. São afirmações que um psicanalista poderia fazer tranquilamente, mas por que Zeno pode fazê-las, uma vez que elas não fazem parte do senso comum e ele não é especialista em bebês, prazer, doença ou psicanálise? Com certeza conta que leu um tratado, mas começa o parágrafo colocando em dúvida a capacidade de lembrar a primeira infância que era defendida no livro, de modo que devemos nos perguntar pela razão segundo a qual, sem ser um especialista, Zeno duvida de algumas ideias psicanalíticas e ratifica outras. Assim, o preâmbulo exemplifica que as associações que se manifestam no presente da escrita fornecem material para investigar o passado mesmo que ela não seja voluntariamente pautada por essa relação temporal.

Logo, a nossa análise dos dois capítulos iniciais sustenta que adotemos uma abordagem para a autobiografia que se distancie daquela adotada por Zeno e que um elemento crucial para a nossa abordagem seria de natureza temporal, a conexão do que se pretende narrar com outros tempos da história de Zeno, inclusive o presente da narração. Como primeira aproximação para a nossa proposta para tal abordagem que supera o âmbito da temporalidade manifestada pelo protagonista e narrador, analisaremos a configuração temporal do início do quinto capítulo por implicar de maneira concentrada as principais temporalidades da autobiografia, algumas delas explicitadas pelo próprio narrador, e por nos dar a oportunidade de começar a investigar como elas são articuladas pe1o texto. O quinto capítulo inicia pelo relato da vida de Zeno imediamente após a morte do pai; citemos os seus primeiros parágrafos:

Nella mente di un giovine di famiglia borghese il concetto di vita umana s'associa a quello della carriera e nella prima gioventù la carriera è quella di Napoleone I. Senza che perciò si sogni di diventare imperatore perché si può somigliare a Napoleone restando molto ma molto più in basso. La vita più intensa è raccontata in sintesi dal suono più rudimentale, quello dell'onda del 
mare, che, dacché si forma, muta ad ogni istante finché non muore! M'aspettavo perciò anch'io di divenire e disfarmi come Napoleone e l'onda. La mia vita non sapeva fornire che una nota sola senz'alcuna variazione, abbastanza alta e che taluni m'invidiano, ma orribilmente tediosa. [...]

Può perciò essere che l'idea di sposarmi mi sia venuta per la stanchezza di emettere e sentire quell'unica nota. ${ }^{62}$ (2004, p. 685)

Comentemos inicialmente como três temporalidades que estudamos neste trabalho são diretamente abordadas e relacionadas entre si nessa citação. No primeiro parágrafo, observamos uma aproximação gradual, irônica e paradoxal entre a concepção linear da vida burguesa, capaz de estabelecer para si uma direção e um destino, e a onda, cuja existência é reduzida à própria mudança, sem aludir a nenhuma ordem ou finalidade. Para entender essa ligação entre elementos tão díspares, precisamos primeiro analisar o restante da citação. Ao referenciar o som da onda, o contraste mencionado também se estabelece num patamar sonoro, usado para opor ambas as concepções de existência baseadas na mudança em relação à concepção da nota única, na qual não há nenhuma variação e o tédio domina. Essa é a temporalidade na qual o protagonista se encontra no momento narrado na citação e é devida à morte do seu pai, conforme já comentamos no capítulo anterior. Zeno afirma que a ideia de casamento surge a partir dessa situação, o que seria uma adesão à direção e ao destino de uma determinada temporalidade linear, a da ordem burguesa, mas apenas para acabar com o tédio, ou seja, pela mudança em si, o que é próprio do que denominamos, desde a seção anterior, de temporalidade de onda, caracterizada pela mudança incessante e sem finalidade.

A partir da citação, retomemos com mais vagar as conexões temporais que estão implicadas no início do quinto capítulo para exemplificar como elas são importantes para que superemos a abordagem de Zeno para a autobiografia. Na citação, são mencionados dois momentos da história do protagonista - um de tédio, sobre o qual não somos informados da sua causa, e outro posterior da decisão de se casar -, e o narrador tenta conectá-los por meio do simples desejo de mudança. Num contexto narrativo tão suspeito, tal tratamento assimétrico dado pelo narrador ao momento de

\footnotetext{
${ }^{62}$ No espírito de um jovem de origem burguesa o conceito da vida humana associa-se ao da carreira e, na mocidade, o que se entende por carreira é a de Napoleão. Não que necessariamente o jovem sonhe em tornar-se imperador, já que é possível assemelharse a Napoleão permanecendo em escala muito inferior. A vida mais intensa pode ser sintetizada pelo mais rudimentar dos sons, o da onda do mar, que, a partir do momento em que se forma, muda sem cessar até o instante em que morre! Eu também aspirava a transformar-me e desfazer-me, a exemplo de Napoleão e da onda.

Minha vida constituía-se de uma única nota, sem variações, certamente alta e invejada por muitos, mas horrivelmente tediosa para mim. [...]

Daí talvez ter-me vindo a ideia de casar-me apenas pelo cansaço de emitir e ouvir aquela mesma nota (2006, p. 67).
} 
tédio não pode ser simplesmente desprezado: Zeno não explicita a sua ligação com os eventos anteriores, mas tematiza enfaticamente o que o ligaria a um evento futuro. Como a posição temporal desse momento não é precisada, o tédio fica situado simplesmente após os acontecimentos que encerram o capítulo anterior: a morte e o funeral do pai. Assim, um primeiro problema narrativo seria o da existência de uma ligação entre essa perda e a condição posterior de enfado. Um segundo problema está aludido no próprio discurso do narrador: o casamento é uma instituição dentro da ordem burguesa da sociedade na qual Zeno vive e, portanto, a ideia de que alguém se case só pela mudança em si é antes contraditória do que explicativa.

Os problemas da conexão proposta no trecho citado não se limitam aos dois que já mencionamos, pois ele não é seguido pelo relato das iniciativas do protagonista para se casar, o que só será feito propriamente com a narração do retorno da viagem da família Malfenti (2004, p. 694) e da primeira visita que Zeno lhe faz; pelo contrário, a conexão proposta simplesmente não opera na parte intermediária formada pelos trechos seguintes ao citado, uma vez que essa parte não fornece nenhuma indicação de que o protagonista pretendesse se casar - exceto já no penúltimo parágrafo, no qual é relatado quando Zeno soube que Giovanni tinha quatro filhas (2004, p. 692-693) - e até mesmo pode ser lida como se Zeno não houvesse pensado em se casar antes de conhecer Giovanni (exceto o parágrafo inicial, seguinte ao último da citação, no qual o narrador introduz a parte intermediária já destacando as estranhezas provocadas pela conexão que propôs), pois o narrador só se refere com antecipação ao casamento no sentido de que Giovanni será o seu sogro.

Não só a parte intermediária sobre a relação com Giovanni e sobre o rompimento de uma relação amorosa não opera com a conexão apontada na citação, mas também fornece indícios de outras ligações para o fim do tédio e para o futuro casamento, de modo que, quanto mais essa parte se prolonga, mais fragiliza essa conexão. De fato, Zeno só conhece Giovanni porque vai à bolsa de valores com o objetivo de assumir os negócios que o pai deixou sob a direção de Olivi (conforme analisamos no capítulo anterior, no qual também expusemos como essa era a primeira de uma série de iniciativas do protagonista com esse objetivo), e a sua relação com Giovanni é apresentada justamente por meio do desejo de novidade que Zeno introduziu como superação do estado de nota única: "Il desiderio di novità che c'era nel mio animo 
veniva soddisfatto da Giovanni Malfenti [...]”63 (2004, p. 686). Esse estado só volta a se instalar no espírito do protagonista após o casamento (2004, p. 800). Além disso, a parte intermediária termina com Zeno rompendo o relacionamento longo com uma mulher justamente quando ela buscava tornar a relação entre eles mais séria sem apresentar razões que inspirem confiança para uma atitude de tal importância (2004, p. 693), o que é exatamente um exemplo contrário à conexão em análise.

Em suma, quando passamos da conexão inicialmente proposta pelo narrador entre o tédio e a decisão de se casar para a narrativa que ele cria entre os dois extremos de tal ligação, encontramos uma sucessão mais complexa de eventos e para a qual ainda precisamos acrescentar o evento anterior àquele ao primeiro da conexão: a morte do pai; o tédio; o encontro com Giovanni, ao qual está vinculado o fim do tédio, e a relação com ele (que antecipa até momentos nos quais Zeno já está casado); a decisão de se casar (que só está atribuída ao protagonista com o uso de tempo passado quando ele é informado sobre as filhas do futuro sogro); e o rompimento com uma antiga amante quando ela tenta tornar mais forte a ligação entre eles. Tal sucessão parece antes passar pela mediação do encontro com Giovanni do que operar segundo a conexão exposta pelo narrador: quanto ao início da sequência, é com o futuro sogro que termina o tédio posterior à morte do pai; quanto ao final dela, a ideia de se casar, no que se refere ao protagonista, não é aplicada especificamente a nenhuma outra mulher que não seja uma das filhas de Giovanni (pelo contrário, Zeno rompe com a única personagem feminina dos eventos em análise). Em concordância com toda a nossa linha argumentiva na presente seção, elegeremos as relações temporais que encontramos efetivamente em operação no texto em detrimento daquelas que Zeno destaca, principalmente caso sejam relações próprias ao âmbito da sua temporalidade manifesta, ou seja, ao embate das temporalidades linear e de onda.

Para finalizarmos a presente análise do início do quinto capítulo, tentemos estabelecer a temporalidade que resulta da sucessão mediada pelo encontro com o futuro sogro. Quanto à primeira parte da mediação, há duas questões principais que requerem investigação: por que o tédio sucede a morte do pai e por que ele termina ao conhecer Giovanni? Por ora, tratemos da segunda pergunta. A nossa resposta se baseia na análise do termo intermediário da sucessão a partir das indicações dadas por Zeno de que concebe Giovanni como uma figura paterna, tanto ao mencionar a suposta amizade

\footnotetext{
${ }^{63} \mathrm{O}$ desejo de novidade que havia em meu espírito encontrou perfeita satisfação em Giovanni Malfenti [...] (2006, p. 68).
} 
entre eles (2004, p. 686) quanto ao sentir-se diminuído pela morte do sogro por perder um segundo pai (2004, p. 692). O texto ratifica essas indicações tanto nas considerações gerais sobre a relação entre eles, como na oposição entre a curiosidade intelectual de um e o desprezo generalizado pelo intelecto do outro (2004, p. 686), quanto nos episódios narrados, seja porque num deles (2004, p. 687) o futuro sogro confirma a decisão do pai de preterir Zeno na direção dos negócios, seja porque o principal tema dos episódios é a rivalidade mútua na forma da competição em torno da atividade comercial (2004, p. 687-691). A repetição das relações paternas tornaria coerente o fato de o tédio, iniciado após a morte do pai, terminar quando o protagonista conhece Giovanni, ainda que não soubéssemos qual fosse a conexão entre a ausência de tais relações e o tédio.

No tocante à segunda parte da mediação, qual seria a relação entre o encontro com Giovanni e a decisão de se casar? A rivalidade também serviria para esclarecer essa ligação? É o que faz o doutor S. no oitavo capítulo (2004, p. 1059-1060): o casamento seria apenas um meio pelo qual o ódio de Zeno atingiria Giovanni. Para o início do quinto capítulo, a mera repetição da rivalidade paterna nos permite considerar como aparentes as duas temporalidades que sustentam a experiência manifesta de Zeno: não há um tempo linear na medida em que as mudanças são apenas meios para manter a repetição das relações paternas nem há, exceto apenas no caso do surgimento do tédio, o acaso das mudanças que vigora na temporalidade de onda na medida em que a repetição da rivalidade permite compreender causalmente o fim do tédio, a relação com Giovanni e a ideia de se casar com uma de suas filhas.

Uma vez que vislumbramos a possibilidade de superação da experiência manifesta do protagonista e narrador por meio da repetição da rivalidade paterna, não há motivo razoável para nos impedir de explorar a hipótese mais geral de que, além das três temporalidades explicitamente elaboradas nos parágrafos iniciais do quinto capítulo, a autobiografia de Zeno seja construída segundo uma quarta, a da compulsão à repetição do recalcado, o qual, neste caso, é o complexo de Édipo. De fato, a consideração de tal hipótese proporciona dois resultados para a nossa argumentação. O primeiro deles é a conclusão da análise final da presente seção, pois fornece a última conexão causal que faltava - a do surgimento do tédio devido à morte do pai - pelo esclarecimento da relação entre a compulsão repetitiva e a temporalidade da nota única e fundamenta o potencial causal da rivalidade ao lhe dar uma base psicopatológica. $O$ segundo resultado é o estabelecimento da ligação entre o capítulo anterior deste trabalho e o presente na medida em que aquele justamente explora o quanto a hipótese da 
compulsão repetitiva do recalcado está amparada pelo texto por meio da ampla disseminação de recorrências no comportamento que nos é relatado do protagonista.

Assim, respondemos à pergunta, com a qual abrimos a presente seção, sobre a superação da temporalidade manifestada por Zeno com a configuração repetitiva do tempo que resulta da noção à qual dedicamos o capítulo anterior deste trabalho, a compulsão à repetição do recalcado. Dedicaremos a próxima seção a prosseguir com o estudo de tal configuração na autobiografia de Zeno por meio da análise dessa compulsão repetitiva no caso do narrador.

\subsection{A configuração temporal da autobiografia de Zeno como superação do âmbito da sua experiência manifesta: a compulsão à repetição do recalcado fora da diegese}

Dedicaremos a presente seção a completar o estudo da compulsão à repetição do recalcado na autobiografia de Zeno a partir da retomada do que elaboramos no capítulo anterior, o qual tratou desse fenômeno compulsivo no que concerne à diegese. Para completarmos a investigação da configuração temporal que resulta da superação do âmbito da experiência imediata de Zeno, devemos ampliar o nosso estudo considerando também as consequências de o narrador operar igualmente segundo a compulsão à repetição.

Comparemos inicialmente a situação final do protagonista na narrativa com a do narrador. Na última seção do capítulo anterior, expusemos a ligação entre dois momentos, os das perdas do pai e de Ada, nos quais o protagonista se encontra em idêntica condição temporal, a da nota única. Pois bem, a mesma temporalidade enseja outra associação no início do quinto capítulo e novamente com o momento da perda do pai, mas não mais entre diferentes segmentos narrativos; neste caso, a condição temporal de tédio liga os tempos da história e da narração de um mesmo segmento narrativo: "La mia vita non sapeva fornire che una nota sola senz'alcuna variazione, abbastanza alta e che taluni m'invidiano, ma orribilmente tediosa"64 (2004, p. 685).

\footnotetext{
${ }^{64}$ Minha vida constituía-se de uma única nota, sem variações, certamente alta e invejada por muitos, mas horrivelmente tediosa para mim (2006, p. 67).
} 
Como comenta a estudiosa Micaela Claar, a citação nos dá uma indicação de que a temporalidade da nota única também vigora para o narrador, graças a uma mistura de tempos verbais que transfere o sentido entre a época narrada e o presente do narrador:

Poiché è chiaro che il passato appartiene ai fatti rievocati e il presente
all'analisi di Zeno, l'accostamento all'imperfetto della narrazione (sapeva) di
un improvviso presente (mi invidiano) che trasferisce l'effetto dell'invidia nel
presente-attualità del protagonista, impedisce al lettore di capire chiaramente
se la considerazione sulla monotonia della sua vita appartenga allo Zeno
dell'epoca dei fatti narrati o allo Zeno narrante. (1986, p. 142)

Logo, o narrador se encontra na mesma disposição temporal da nota única, tal como o fim da autobiografia nos entrega o protagonista. De fato, nenhum dos episódios cronologicamente posteriores, como o do doutor Muli, altera a situação do protagonista para além da duração do próprio episódio. Em suma, Zeno se tornou narrador, mas continua tão doente quanto antes e, portanto, compelido a repetir, o que não poderá passar despercebido justamente pelo seu desempenho como narrador ao longo da autobiografia.

Se a compulsão à repetição também é determinante para o narrador, devemos considerar a autobiografia de Zeno como sendo constituída por duas grandes séries repetitivas, as do protagonista e do narrador, que são temporalmente distintas, mas se encontram justamente na elaboração da narrativa. Assim, não acompanhamos simplesmente a sucessão das mudanças nas interferências entre as repetições do protagonista, que analisamos minuciosamente no capítulo anterior deste trabalho, pois há uma interferência mútua entre as repetições do narrador e o relato do comportamento repetitivo do personagem que faz com que o texto tenda a se distanciar em alguma medida da experiência vivida por Zeno no tempo da história para oferecer a experiência que ele tem de recordá-la e narrá-la ao se preparar para uma terapia psicanalítica, o que inclui a perspectiva do protagonista em variados graus de distorção.

Aproveitemos os resultados que obtivemos no capítulo anterior sobre a compulsão à repetição na diegese da autobiografia para explorar as repetições do narrador em função da sua relação com as séries repetitivas do protagonista, começando pelo grupo daquelas cuja relação é de máxima convergência e progredindo até o grupo da divergência máxima.

O grupo no qual a convergência entre as repetições do protagonista e do narrador é máxima é formado pelas repetições daquele que voltam a ser repetidas de algum modo próprio apenas ao narrador, ainda que não haja acréscimo de elementos 
alheios ao momento em questão da história, ou são integralmente compartilhadas por ambos, distintas apenas pelo momento das respectivas ocorrências.

A repetição própria ao narrador de uma repetição do protagonista é uma reação daquele à história narrada que acrescenta algo ainda vinculado ao momento diegético. Um dos exemplos mais drásticos pertence à série do vício de fumar: "Ancora oggi mi pare che se quella data [primeiro de janeiro de 1901] potesse ripetersi, io saprei iniziare una nuova vita" ${ }^{\circ 5}$ (2004, p. 634). Ao narrar, Zeno reproduz de modo imaginário a reação que teve ao dia mencionado no momento da sua ocorrência; além disso, a própria impossibilidade de a data se repetir sugere a sua incapacidade de iniciar uma nova vida, ou seja, de não continuar a repetir. Em suma, a série repetitiva do tabagismo continua em plena operação no narrador.

Apesar da data do exemplo do parágrafo anterior ser única, o narrador continua a ter o hábito de fumar; no entanto, isso não implica que haja necessidade de uma vivência explicitamente contínua para que ele repita diretamente o protagonista. De fato, até mesmo repetições que produzam um sentimento que se destaca pela sua ocorrência única na história podem ser diretamente repetidas pelo narrador, como acontece no único episódio no qual somos informados de que o protagonista teve um sentimento trivial de ciúmes pela esposa, o do doutor Muli. Conforme analisamos no capítulo anterior, o episódio está baseado num complexo conflito de repetições do personagem, do qual um dos resultados são esses ciúmes inéditos. Pois bem, após Zeno contar que foi a esposa que teve a ideia da internação, comenta que era a primeira vez que ela o auxiliava a tentar parar de fumar e que antes ela nunca tratara com seriedade o que ele considerava uma doença. A esse respeito, Zeno faz um gracejo irônico: "Io credo ch'essa [Augusta] fosse stata sorpresa gradevolmente dopo di avermi sposato di non sentirmi mai rimpiangere la mia libertà, occupato com'ero a rimpiangere altre cose" 66 (2004, p. 641). Apesar do vínculo ao contexto mais imediato, o gracejo também se refere à noção de liberdade para além da mera perda dela devido a uma internação: com a menção à liberdade das pessoas solteiras, o narrador já se adianta à conotação sexual que essa noção ganha na própria história relatada e, portanto, repete o sentimento de ciúmes que sentiu como protagonista pela primeira e última vez nesse episódio.

\footnotetext{
65 Ainda hoje sinto que se fosse possível repetir a data [primeiro de janeiro de 1901] eu saberia como iniciar nova vida (2006, p. 21).

${ }^{66}$ Acho que constituiu para ela [Augusta] surpresa agradável constatar que depois de nosso casamento jamais lamentei a perda de minha liberdade, preocupado que estava em lamentar outras coisas (2006, p. 27).
} 
Para completar o primeiro grupo das repetições do narrador, abordemos aquelas que são integralmente compartilhadas com o protagonista. O modo mais eficiente de realizar isso é compartilhar o próprio enunciado narrativo por meio do discurso indireto livre, no qual as instâncias do personagem e do narrador estão confundidas, como expusemos no primeiro capítulo. O sentimento de ciúmes do narrador por Augusta e pelo doutor Muli é expresso dessa forma nos momentos de maior impacto emocional, como nos exemplos a seguir: "Una folle, amara gelosia per il giovine dottore. Lui bello, lui libero!"67 (2004, p. 644) e "Ecco dove m'aveva condotto la fiducia in mia moglie!"68 (2004, p. 646). Outra repetição compartilhada da competição sexual por meio dos ciúmes, dessa vez por Ada, ocorre na forma de sentenças em discurso indireto livre que operam como reação à tentativa dela e de Guido de disfarçarem que estavam se beijando (2004, p. 851). Também é um recurso frequente em pensamentos conjecturais, cuja autoria muitas vezes não é elucidada, como nessa conjunção entre as séries de repetições do tabagismo e dos cuidados com a saúde por meio da expectativa de que o médico o proíbisse de fumar: "Chissà come sarebbero andate le cose se allora fossi stato fortificato nei miei propositi da una proibizione simile"69 (2004, p. 636). Apesar de ser um uso comum desse tipo de discurso, não é o único, conforme argumentaremos ainda neste capítulo.

Também há ocorrências mais simples da repetição compartilhada pela menção explícita ao fato de o narrador repetir o protagonista, como no caso do desgosto que Zeno ainda sente ao evocar a situação na qual o pai quase o surpreende roubando os trocados deixados no bolso do colete e que Zeno atribui de modo suspeito à desfaçatez (afinal, ele não é nenhum paradigma de moralidade para que esperemos tais demonstrações de escrúpulos) com a qual engana o pai (2004, p. 629). Consideramos que tanto o desgosto que volta a se manifestar no narrador quanto a causa que lhe atribui são ocorrências da hostilidade velada, conflito entre repetições que estudamos no capítulo anterior, durante a escrita de Zeno.

O segundo grupo das repetições do narrador é formado por aquelas que ainda convergem com as do protagonista, mas acrescentando elementos alheios ao momento em questão da história, de modo que tais repetições nos desviam, em maior ou menor grau, da experiência do protagonista. A variedade de tais elementos é bem grande; pode

\footnotetext{
${ }^{67}$ Um estúpido e amargo ciúme pelo jovem doutor. Ele era bonito, livre (2006, p. 30)!

${ }^{68}$ Eis aonde me havia conduzido a confiança em minha mulher (2006, p. 31)!

${ }^{69}$ Quem sabe as coisas tomariam outro rumo se meus propósitos fossem fortificados por uma tal proibição (2006, p. 22)?
} 
ser até mesmo algo que não seja próprio ao tempo da narração por meio da antecipação de um momento posterior da história. Como exemplo dessa situação, mencionemos que, antes de o narrador nos oferecer qualquer ocorrência da série dos últimos cigarros do protagonista, ele fuma o primeiro cigarro do romance a ser qualificado de último, justamente em reação às recordações do início do seu vício tabagista: "Ecco che ho registrata l'origine della sozza abitudine e (chissà?) forse ne sono già guarito. Perciò, per provare, accendo un'ultima sigaretta e forse la getterò via subito, disgustato"70 (2004, p. 629). A repetição do narrador não questiona aquelas que narrou sobre o protagonista; pelo contrário, a reforça ao antecipar a forma que assumirá depois de alguns anos.

Apesar do exemplo que demos no parágrafo anterior, o mais comum é que os elementos alheios sejam próprios ao tempo da narração, ou seja, não pertençam ao tempo da história da autobiografia. Tais elementos podem ser triviais como a velhice, que proporciona duas considerações, ainda que contraditórias, sobre o hábito de fumar envolvendo a etapa final da vida (2004, p. 632-633), ou mais inesperados, como a observação sobre a atual disposição da sala da infância ao lembrar de estar deitado no sofá junto à mãe após uma excursão da escola:

[...] come se fossi adesso là accanto a quel caro corpo [da mãe] che più non esiste.

Ricordo la stanza fresca e grande ove noi bambini si giuocava e che ora, in questi tempi avari di spazio, è divisa in due parti. In quella scena mio fratello non appare, ciò che mi sorprende perché penso ch'egli pur deve aver preso parte a quell'escursione e avrebbe dovuto poi partecipare al riposo. Che abbia dormito anche lui all'altro capo del grande sofà? Io guardo quel posto, ma mi sembra vuoto. Non vedo che me, la dolcezza del riposo, mia madre [...]. ${ }^{71}$ (2004, p. 630)

O narrador interrompe o relato para comparar a sala grande e fresca na qual as crianças brincavam com as duas partes nas quais ela se encontra dividida no momento da narração, supostamente por avareza de espaço. O fato de ele próprio não esclarecer o motivo para interromper a narrativa com uma comparação sem consequências para o que está relatando é um indício de uma possível associação livre pela qual se torna

\footnotetext{
${ }^{70}$ Mas com isso já registrei a origem do hábito pernicioso e (quem sabe?) talvez assim já esteja curado. Para certificar-me, vou acender um último cigarro, que talvez atire fora em seguida, enojado (2006, p. 16).

${ }^{71}[\ldots]$ como se eu ainda estivesse lá, junto daquele corpo [da mãe] que não existe mais. Recordo a sala grande e fresca onde nós, crianças, brincávamos e que hoje, nestes tempos ávidos de espaço, foi dividida em duas. Meu irmão não aparece nesta cena, o que muito me surpreende, pois creio que certamente participara da excursão e teria, portanto, igual direito ao repouso. Também teria sido posto a dormir, no outro braço do sofá? Olho para o local, mas me parece vazio. Vejo apenas a mim, a delícia do repouso, minha mãe [...] (2006, p. 17).
} 
viável uma manifestação indireta de conteúdos recalcados de Zeno e, portanto, de mais uma ocorrência de uma repetição do recalcado. Nesse sentido, a provável presença do irmão, que é introduzida na sentença seguinte da citação, nos sugere que se trata de uma repetição pelo narrador da tradução da rivalidade em termos espaciais ou respiratórios, uma das séries repetitivas do protagonista que analisamos no capítulo anterior. De fato, ainda que Zeno não consiga lembrar, é provável que o irmão dividisse o espaço do sofá com o protagonista e, portanto, a proximidade com o corpo da mãe.

Além disso, seria coerente com outras apropriações aparentemente plausíveis que Svevo haja feito de elaborações pontuais do livro de Freud sobre a interpretação dos sonhos, as quais ainda abordaremos no presente capítulo, que a comparação entre a sala no passado e no presente também seja uma repetição do narrador do desejo pela mãe, cujo corpo próximo é relembrado com a intensidade de uma sensação atual na sentença anterior à da comparação. Mais obscura por ser mais intensamente recalcada, tal repetição seria baseada na seguinte observação:

Encontramos um vínculo interessante com as investigações sexuais da
infância quando alguém sonha com dois quartos que eram originalmente um
[...]. Na infância, os órgãos genitais femininos e o ânus são considerados
como uma área única - o "traseiro" (segundo a "teoria da cloaca" própria da
infância), e só mais tarde é que se faz a descoberta de que essa região do
corpo compreende duas cavidades e orifícios separados. (FREUD, 1987a, p.
336)

Assim, a comparação não seria apenas entre duas configurações espaciais para o mesmo lugar, mas também entre duas configurações anatômicas para o mesmo desejo do protagonista ainda criança e do narrador pelo corpo materno.

Começamos explorando dois elementos próprios ao tempo da narração que operam de modo muito pontual na autobiografia. Uma vez que terminamos essa etapa introdutória, tratemos dos elementos que se destacam pela sua operação recorrente ao longo do texto; mais precisamente, são aqueles que resultam da ação primária do narrador, a terapia com o doutor S.: o tratado psicanalítico que leu por conta própria e a escrita autobiográfica que lhe foi prescrita.

Com a leitura do tratado, Zeno aprimora o seu conhecimento sobre psicanálise, ao qual foi introduzido pela consulta com o doutor S., e isso contribui para as suas repetições como narrador. Poucas são explícitas, como acontece quando ele repete com a psicanálise a exigência que o protagonista fez ao tratamento pela eletricidade de controlar o seu desejo, que tende a se destinar a diversas mulheres (2004, p. 637). A propósito, depois das diversas repetições de cuidados com a saúde do protagonista, não 
deve nos surpreender que a própria terapia psicanalítica seja a continuação dessa série por parte do narrador.

Além disso, os efeitos da leitura do tratado podem ocorrer sem qualquer referência à psicanálise. É o caso dos comentários feitos à inversão no sonho com o médico Coprosich (2004, p. 676-677), ao olhar que o protagonista embriagado dirige para Ada (2004, p. 867-868) e à declaração sobre a originalidade da vida (2004, p. 972).

Quanto ao primeiro comentário, consiste em propor que a inversão ocorrida no sonho do narrador - ao contrário do que ocorreu, Zeno imagina exigir que as sanguessugas sejam aplicadas ao pai - seja devida ao "instrumento ótico" que é capaz de produzi-lo. A sucinta proposição do narrador é suspeita tanto porque não está claro o motivo para fazê-la, dado que é uma constatação trivial a de que a realidade seja alterada pelos sonhos, quanto porque a sua capacidade explicativa é bem baixa. A nossa suspeita se torna ainda maior justamente por se tratar de uma inversão onírica, um fenômeno amplamente destacado pela psicanálise. Logo, consideramos que o narrador sente necessidade de se defender exatamente por causa do conhecimento adquirido com o tratado psicanalítico e que a defesa consiste no fato de que a inversão independa do seu desejo; mais precisamente, que seja efeito da própria produção do sonho, o que sustentaria a comparação implícita com as imagens invertidas que são produzidas por certos instrumentos óticos. Em suma, o narrador repete duas vezes o desejo de que o pai morra: uma vez por meio do próprio sonho, no qual a reprodução do ato do protagonista de impedir a aplicação das sanguessugas é distorcida pela inversão onírica, e outra vez ao evitar o reconhecimento desse desejo atribuindo outra causa para a distorção, o que implica um elemento alheio ao da época da morte do pai, que é o conhecimento psicanalítico sobre tais fenômenos.

No tocante ao caso no qual Zeno está embriagado, a situação que suscita o comentário do narrador são duas manifestações consecutivas do desejo do protagonista por Ada: os pensamentos pelos quais tenta se convencer de que não a deseja e o olhar cheio de desejo que lhe dirige. Zeno, o narrador sóbrio e já afastado da visão da mulher desejada, pode repetir o desejo por Ada do primeiro modo negando que a desejasse quando the dirigiu aquele olhar. Parece fazer isso recorrendo a uma determinada distorção do que é revelado sobre o passado e o presente do sujeito em condições nas quais sobrepuja o seu controle consciente, como Freud estudou no que tange, por exemplo, aos sonhos e aos atos falhos. Enquanto a psicanálise defende que tais condições revelariam manifestações menos distorcidas do que ainda se encontra sob a a 
ação do recalque e, portanto, de algo passado que persiste no presente, o narrador argumenta que a embriaguez revelaria um momento passado sem as mudanças posteriores, de modo que o ato do protagonista bêbado expressaria algo já superado.

Quanto ao episódio da originalidade da vida, também há uma relação de reforço entre as distorções do protagonista e do narrador. Para começar, devemos observar que o passeio noturno de Guido e Zeno no episódio repete semelhante passeio que ambos fizeram quando se conheceram, o que é recordado por ambos. Apesar de relação tão notável, o protagonista resolve afirmar que a vida é original. Trata-se de uma avaliação altamente descabida, pois não só há a reconhecida repetição das caminhadas, mas também o ódio de Zeno por Guido é a ligação crucial entre as duas: a segunda é motivada pela apresentação que o protagonista faz para Guido do desastroso balanço do primeiro ano da empresa, e o balanço é uma etapa no processo de vencer o concunhado sem matá-lo, o qual começou no primeiro passeio, quando Zeno teve a oportunidade de cometer o assassinato, mas renunciou a fazê-lo. A mesma necessidade que o protagonista teve de distorcer a repetição na qual incorria parece voltar a acometer o narrador ao recordar e relatar o episódio em análise, pois esse relato possui dois períodos que recorrem à noção de associação casual para presumivelmente justificar o despropositado surgimento da ideia de originalidade da vida. Ora, as associações livres de ideias são justamente um elemento fundamental da psicanálise, como comentamos ao tratar da declaração do doutor S. no preâmbulo, segundo a qual o presente da escrita fornece material para investigar o passado. Logo, tal repetição do narrador também seria um efeito da leitura do tratado.

Apesar de ser um acontecimento do tempo da narração, a leitura do tratado psicanalítico pode até mesmo influenciar o que aparentemente estaria restrito ao tempo da história. Isso ocorre por meio de um procedimento bastante específico, o qual denominamos de sobreposição silenciosa de um tempo mítico. Verifiquemos como ele opera por meio do estudo dos relatos sobre o doutor Coprosich e sobre o primeiro sonho com Ada, nos quais a escrita do narrador remete implicitamente à tragédia de Édipo em referência ao complexo homônimo. No primeiro caso, o tempo mítico é introduzido pela identificação do doutor Coprosich com o profeta cego Tirésias, aquele que diz ao rei Édipo que ele assassinou Laio (ainda que não lhe esclareça que este era o pai do rei). A identificação ocorre durante a visita que o médico faz à família Cosini ao ser chamado para tratar do pai moribundo e é feita principalmente pelos seus olhos, pois, quando está sem óculos, fica praticamente tão cego quanto Tirésias. São quatro os principais trechos 
nos quais ocorre esse processo, todos sempre se referindo a Coprosich:

Un'altra sua debolezza gli dava dell'importanza: quando levava gli occhiali (e lo faceva sempre quando voleva meditare) i suoi occhi accecati guardavano accanto o al disopra del suo interlocutore e avevano il curioso aspetto degli occhi privi di colore di un statua, minacciosi o, forse, ironici. Erano degli occhi spiacevoli allora.

[...] Mi domandò di raccontargli esattamente quello ch'era avvenuto dal primo allarme fino al suo arrivo. Si levò gli occhiali e fissò con i suoi occhi strani la parete dietro di me.

[...] Anzi aveva creduto che lo avessimo abbandonato per altro medico; egli allora aveva ben chiaramente dichiarato che mio padre abbisognava di cure. Quando rimproverava, così senz'occhiali, era terribile. Aveva alzata la voce e voleva spiegazioni. I suoi occhi le cercavano dappertutto.

[...] Egli s'agitò tanto che dimenticò d'inforcare gli occhiali e tuttavia scoperse esattamente il punto ove si trovava la mia testa per fissarla con i suoi occhi terribili. Mi disse che gli pareva io volessi recidere anche quel tenue filo di speranza che vi era ancora. Me lo disse proprio così, crudamente. ${ }^{72}(2004$, p. $670-673)$

Inicialmente o narrador apresenta o hábito do médico de tirar os óculos e o aspecto dos seus olhos sem esse aparato: são como os de um cego e incolores como os de uma estátua. É um motivo livre, pois nada mudaria na história de Zeno se Coprosich não tivesse esse hábito. Ainda assim, o narrador não só se refere mais de uma vez a isso, mas também qualifica os olhos nesse estado e informa a direção à qual estão voltados. Os olhos sem óculos são qualificados de ameaçadores, irônicos, desagradáveis, estranhos e terríveis. Quanto à direção, parece haver uma gradação. Quando o médico solicita as primeiras informações sobre o caso que veio atender, ele simplesmente não olha para o interlocutor, como já havia sido informado na apresentação do hábito, mas os olhos "cegos" passam a buscar algo quando ele descobre que o moribundo não fez o tratamento necessário e encontram o protagonista quando este é acusado de querer que o pai morra. Com esse processo de identificação de Coprosich com Tirésias, o narrador despreza o médico que foi chamado para salvar o pai moribundo para sobrepô-lo pelo profeta que acusa Zeno-Édipo de parricídio, o que propicia tanto mais uma repetição do

\footnotetext{
${ }^{72}$ Outro defeito que lhe dava também importância: quando tirava os óculos (e o fazia sempre que queria meditar), os olhos míopes [sic] miravam para o lado ou por cima de seu interlocutor e mostravam o curioso aspecto dos olhos sem cor das estátuas, ameaçadores ou, talvez, irônicos. Eram então desagradáveis.

[...] Pediu-me que lhe contasse exatamente o que havia ocorrido desde o primeiro sinal de perigo até o momento de sua chegada. Tirou os óculos e fitou com seus olhos enviesados [sic] a parede atrás de mim. [...] Chegou a insinar que talvez o tivéssemos abandonado por outro médico; quando o consultamos, chegou a dizer que meu pai necessitava de tratamento. Ao repreender-me, assim sem os óculos, mostrouse terrível. Tinha erguido a voz e queria uma explicação. Seus olhos buscavam-na por toda a parte.

[...] Estava tão agitado que se esqueceu de colocar os óculos; mesmo assim descobriu perfeitamente onde se achava a minha face para fixá-la com os olhos terríveis. Falou que eu parecia querer partir até mesmo o tênue fio de esperança que ainda nos restava. Disse-me isso exatamente assim, de maneira crua (2006, p. 54-57).
} 
desejo de matar o pai quanto uma repetição da rivalidade contra Coprosich, pois não só este é transfigurado de acusador em profeta da realização do desejo parricida, mas também tal profecia engloba a derrota do próprio médico por não conseguir salvar a vida do pai de Zeno.

No caso do primeiro sonho com Ada, a sobreposição silenciosa do tempo mítico ocorre no final do seu relato, após Zeno dizer que Ada está curada do mal de Basedow e perguntar onde ele está. Além desse trecho, a nossa análise também depende de outro do segundo sonho. Eis os trechos que nos importam dos dois sonhos:

\begin{abstract}
"Non vedi?" domandò Augusta ch'era la sola fra di noi che arrivasse a guardare sulla via. Con uno sforzo ci sporgemmo anche noi e scorgemmo una grande folla che s'avanzava minacciosa urlando. [...] Era lui [Basedow] che s'avanzava inseguito da quella folla: un vecchio pezzente coperto di un grande mantello stracciato, ma di broccato rigido [...]. E la folla urlava: "Ammazzate l'untore!".

[...] Ada era posta per alcuni scalini più in alto, ma rivolta a me ch'ero in atto di salire, mentre lei sembrava volesse scendere. Io le abbracciavo le gambe e lei si piegava verso di me non so se per debolezza o per essermi più vicina. Per un istante mi parve sfigurata dalla sua malattia, ma poi, guardandola con affanno, riuscivo a rivederla come m'era apparsa alla finestra, bella e sana. Mi diceva con la sua voce soda: "Precedimi, ti seguo subito!". Io, pronto, mi volgevo per precederla correndo, ma non abbastanza presto per non scorgere che la porta della mia soffitta veniva aperta pian pianino e ne sporgeva la testa chiomata e bianca di Basedow [...]. Arrivai a correre via, ma non so se per precedere Ada o per fuggirla. ${ }^{73}$ (2004, p. 962)
\end{abstract}

Pelo segundo parágrafo citado, podemos verificar que há uma ambivalência na relação com Ada devido ao mal de Basedow: por três vezes, o sonhador coloca pares de alternativas a respeito dela, que parecem compartilhar uma associação entre o desejo por ela e a doença. Ora, a nossa primeira hipótese poderia ser simplesmente de que se trata de uma expressão onírica para o conflito entre a atração sexual por Ada, que o protagonista recalcou, e a doença, que tenderia a afastá-lo da mulher desejada, por repugnância ou qualquer outra razão. Consideramos que essa hipótese seja insuficiente porque o próprio Zeno apresenta complicações para ela por meio de uma das suas

\footnotetext{
73 "Não vê?", perguntou Augusta, que era a única de nos [sic] a conseguir ver a rua. Com um esforço, debruçamo-nos também e percebemos uma grande multidão que avançava ameaçadoramente a gritar. [...] Era ele [Basedow] que seguia acompanhado pela multidão: um velho andrajoso coberto por um grande manto esfrangalhado, de brocado rígido [...]. E a multidão gritava: "Morte ao propagador da peste!" [...] Ada se achava alguns degraus acima de mim, voltada em minha direção; eu subia, ela parecia querer baixar. Abracei-lhe as pernas e ela se curvou para mim, não sei se em decorrência de sua fragilidade ou se para ficar mais junto de mim. Por um momento pareceu-me desfigurada pela moléstia; logo, olhando-a com atenção, consegui vê-la novamente tal como havia aparecido à janela, saudável e bela. Dizia-me com a voz firme: "Vá na frente que sigo você!". Voltei-me para precedê-la correndo, mas sem deixar de perceber que a porta do sótão começava a entreabrir-se devagar e que por ela passava a cabeça branca e eriçada de Basedow [...]. Consegui correr na frente, não sei se para preceder Ada ou se para fugir dela (2006, p. 312-313).
} 
reações (que ele chama de doença) quando sabe da enfermidade da cunhada, a qual incluiria as perversões psíquicas entre os seus distúrbios:

La mia malattia fu un pensiero dominante, un sogno, e anche uno spavento. Deve aver avuto origine da un ragionamento: con la designazione di perversione si vuole intendere una deviazione dalla salute, quella specie di salute che ci accompagnò per un tratto della vita. Ora sapevo che cosa fosse stata la salute da Ada. Non poteva la sua perversione portarla ad amare me, che da sana aveva respinto $?^{74}$ (2004, p. 958-959)

Assim, antes do que fazer com que o protagonista passe a rejeitar Ada, a doença faz com que ele volte a ter esperança de que ela possa amá-lo. Essa mudança não se opõe ao desejo pela cunhada, porém o fato de a mulher desejada passar a sentir atração por ele devido a uma patologia permite que uma simples operação de simetria crie suspeitas sobre o seu desejo por Ada ter origem patológica. Ora, tais suspeitas são passíveis de conflito com a condição recalcada de a cunhada ser uma substituta da relação de Zeno com a mãe, de modo que os sinais patológicos de Ada no segundo sonho seriam efetivamente projeções de Zeno para a própria doença e, portanto, o que lhe perturba o desejo por Ada seria o reconhecimento iminente de que a sua sexualidade está doente.

Se o reconhecimento da doença da própria sexualidade torna mais plausível o conflito do sonhador em relação ao desejo por Ada, apenas a sua repetição por parte do narrador no primeiro sonho apresenta um elemento simbólico de mediação que permite isolar o conflito em análise com mais nitidez. Esse simbolismo é produzido por uma nova sobreposição silenciosa do tempo mítico, outra vez por meio da tragédia de Édipo, e consiste na associação entre a personificação onírica de Basedow e o herói trágico de um período específico, no qual já foi descoberto que ele é o assassino de Laio, e, portanto, a causa da peste que é lançada como castigo contra Tebas em razão desse crime. Tal como o velho do primeiro sonho, Édipo também é um propagador da peste perseguido por uma multidão, o povo de Tebas. Além disso, depois de banido, ele é descrito assim por Sofócles: "Viveste muito, é óbvio" (1998, p. 110) e "Identificam-te os andrajos" (1998, p. 134). Ora, Zeno inicia a descrição de Basedow justamente identificando-o como um velho andrajoso e, além disso, menciona um grande manto esfrangalhado feito de brocado rígido, alteração que acompanha a decadência de Édipo,

\footnotetext{
74 A minha enfermidade consistia numa ideia fixa, um sonho, e mesmo um pesadelo. Deve ter-se originado de uma reflexão: sob o nome de perversão queremos significar um desvio da saúde, aquela espécie de saúde que nos acompanhou por um período de nossa vida. Agora sabia em que consistia a saúde de Ada. Não poderia sua doença levá-la a amar-me, a mim que repelira quando estava boa (2006, p. $310)$ ?
} 
de rei a miserável: a qualidade do brocado denuncia a origem do manto em uma classe rica, mas o seu estado atual é condizente com o mendigo que o veste.

Logo, consideramos que o narrador acrescenta involuntariamente traços de Édipo ao relato do primeiro sonho do protagonista com Ada numa repetição do conflito já operante no sonhador e que o fato de que ele evoque traços do mendigo banido em vez do rei poderoso se deve ao seu temor das consequências do conflito caso efetivamente reconheça a própria sexualidade doente: o fim do seu desejo, o qual é evocado pela decadência de Édipo depois que descobriu a verdade sobre os atos que cometeu envolvendo os seus pais.

Uma vez que terminamos de analisar as repetições do narrador que resultam da leitura do tratado psicanalítico, abordemos aquelas cujo elemento alheio ao protagonista resulta diretamente da própria escrita autobiográfica que lhe foi prescrita, das quais examinaremos dois casos a seguir ao passo que trataremos de outros casos ao analisarmos o próximo grupo de repetições da presente seção. No primeiro caso, tratamos de uma condição intrínseca à escrita autobiográfica: para que Zeno escreva a própria história, é necessário que seja capaz de recordá-la. As repetições do narrador também operam em tal capacidade. Talvez o melhor exemplo dessa operação seja o esquecimento de corpos de certas personagens da época da infância de Zeno no terceiro capítulo. Comecemos observando que Zeno lembra palavras, lugares e até as roupas usadas pelos garotos que venceu numa competição envolvendo cigarros, mas não lembra os seus corpos (2004, p. 631). Ainda que de modo indireto, a constituição corpórea de Olivi também é objeto de esquecimento, pois a afirmação do narrador de que crê que o aspecto do administrador, o qual já trabalhava para o pai de Zeno há muitos anos, sempre foi igual ao do momento da narração (2004, p. 640) equivale a declarar que não lembra o seu aspecto passado. No caso do pai, o seu corpo nem mesmo é mencionado. Por fim, há o episódio com a mãe no sofá (2004, p. 629-631), no qual o contraste é máximo, pois Zeno não tem nenhuma reminiscência da presença do irmão ao passo que lembra o próprio corpo e o da mãe na sensação evidente que tem ao recordar o descanso no sofá.

As observações que reunimos no parágrafo anterior expõem o contraste muito forte que se destaca na recordação de corpos da infância de Zeno, o que propomos ser causado por repetições edipianas do narrador operando sobre tais lembranças, pois os corpos esquecidos são justamente dos rivais edipianos e o único corpo alheio do qual se recorda é o da mãe. 
O segundo caso no qual a repetição do narrador é específica da própria escrita autobiográfica é o dos episódios que são encadeados segundo essas repetições, de modo que elas são uma causa do próprio tempo da narrativa. Isso ocorre, por exemplo, nas tentativas de parar de fumar que encerram o terceiro capítulo, pois cada tentativa está conectada às anteriores pela reação do narrador aos efeitos que provocaram a narração delas

De fato, ao recordar a frustração por não ter a sua doença compreendida pelo médico do tratamento com eletricidade (2004, p. 635-638), Zeno repete a rivalidade edipiana contra ele contando o próximo episódio, que inicia justamente afirmando que quem melhor entendeu a sua doença não foi um médico, mas um amigo literato (2004, p. 638). Além disso, ao relatar como esse amigo descreve o seu distúrbio em termos da relação de conflito entre o senhor e o escravo (2004, p. 639), a qual consideramos que Zeno associa com a sua relação com o rival Olivi (dado que este seria como um escravo que se tornou o senhor dos negócios que Zeno deveria controlar após a morte do seu pai), o narrador é compelido a hostilizar o rival, o que lhe é propiciado não só pelo episódio da aposta (2004, p. 640), no qual o xinga, declara que não gosta dele e o acusa de tentar diminuir a herança materna, mas também, ainda que apenas pela recordação de hostilidades passadas, pelo relato da internação na clínica do doutor Muli (2004, p. 640652), no qual - como analisamos no capítulo anterior - a internação é uma ação pela qual o protagonista indireta mas tenazmente expressa o desejo de que o rival morra e de substituí-lo no controle dos próprios negócios.

Apesar da convergência entre as repetições de rivalidade do narrador e do protagonista com Olivi e o médico do tratamento com eletricidade, o tempo da narrativa encadeado pelas repetições do narrador está no limite de tal convergência, pois a ruptura com a cronologia destaca as variações de uma mesma situação básica, a das tentativas fracassadas para parar de fumar, e, portanto, a própria repetição é mais destacada nessa sequência de episódios do que na história do protagonista. Apenas não nos parece que esse limite seja ultrapassado porque o narrador não manifesta um reconhecimento da recorrência no caso da própria situação na qual se encontra: a própria terapia psicanalítica se apresenta como uma potencial tentativa fracassada para parar de fumar, que daria continuidade à sequência narrada, inclusive compartilhando o recurso a um terapeuta com dois dos seus episódios.

O terceiro e último grupo das repetições do narrador é formado por aquelas que divergem das repetições do protagonista, o que ocorre devido à diferença entre as 
situações de Zeno nos tempos da história e da narração. A incapacidade do narrador de entender o que recorda devido ao processo de recalcamento faz com que essa diferença não seja superada na narrativa; pelo contrário, ela cria descompassos entre as vivências do protagonista e os relatos correspondentes do narrador que perturbam o tecido narrativo.

A partir da apresentação que fizemos do parágrafo anterior já podemos suspeitar o quão afastada a escrita de Zeno está daquela relação comum na narrativa autobiográfica segundo a qual o narrador trata o protagonista com uma superioridade condescendente ou irônica, conforme a citação que fizemos de Genette no primeiro capítulo deste trabalho. De fato, os dois primeiros grupos que analisamos na presente seção equiparam as duas instâncias narrativas de Zeno ao abarcarem as repetições do narrador que continuam a operar, ainda que com outros elementos, como as do protagonista, e o grupo que começamos a estudar esclarece que mesmo as repetições divergentes de ambos se devem apenas a diferentes arranjos das mesmas recorrências edipianas, de modo que a nossa proposta é de que não haveria uma superação da compulsão repetitiva de Zeno, seja pelo processo de envelhecimento do protagonista, seja pela sua nova condição de narrador ao seguir a prescrição de escrever sobre a própria vida.

As principais repetições divergentes estão distribuídas do quarto ao sétimo capítulos e podem ser agrupadas em dois tipos. Investiguemos como eles efetivamente operam. O primeiro tipo opera por intervenções do narrador, sejam elas próprias a ele ou em enunciados compartilhados com o protagonista. No capítulo quarto, várias intervenções do narrador assumem uma forma especial de remorso que constitui mais uma repetição da hostilidade velada, como nas compensações operadas pelo protagonista devido a violações do limite desse tipo de hostilidade, conforme expusemos no capítulo anterior. Dentre essas intervenções, aquelas que acontecem antes que a doença paterna se manifeste definitivamente são repetições divergentes, pois nelas o narrador adianta um remorso ligado à morte do pai que o protagonista só demonstrará após a gravidade da doença se tornar clara.

As principais ocorrências do remorso divergente estão no jantar com o pai na noite na qual ele começa a sucumbir à doença (2004, p. 661-664). Por um lado, no episódio inteiro, a conduta hostil do protagonista contra o próprio genitor só é suspensa por breves dúvidas sobre o seu estado de saúde, que logo são descartadas em favor de outra hipótese para o seu comportamento. Por outro lado, Zeno, como narrador, sabe 
que a doença fatal já se apossou do pai e não consegue referendar pela simples narração as atitudes pelas quais fica mais clara a rivalidade do protagonista contra o pai já combalido pela enfermidade, de modo que recorre ao remorso fazendo algumas intervenções que destacam a incapacidade que teve em reconhecer a moléstia paterna, mas, por sua vez, é incapaz de reconhecer a hostilidade como causa dessa incapacidade; pelo contrário, pretende apenas haver falhado em perceber que o pai estava gravemente enfermo e, portanto, em agir de modo condizente com tal situação, seja sendo mais afetuoso, seja chamando um médico imediatamente. A repetição da rivalidade edipiana também se revela pelo fato de o narrador, nas duas intervenções nas quais formula hipóteses sobre o comportamento paterno, continuar a pensar em termos de hostilidade, mas distorcida por ser deslocada para o rival, que só estaria evitando o confronto pelo desvio do olhar e por não afrontar o ceticismo religioso do filho porque a doença o haveria deixado numa condição frágil.

No quinto capítulo, as principais intervenções divergentes do narrador estão fundadas em duas diferenças entre o seu desejo edipiano por Ada e a situação do protagonista. A primeira diferença influi no relato da escolha de uma das irmãs Malfenti como esposa. Para o protagonista, as situações inicial e final dessa escolha são dominadas pela arbitrariedade, pois no começo ela pode recair indiferenciadamente em qualquer uma das quatro irmãs e no final ele pede em casamento as três para as quais pode fazer o pedido. $\mathrm{O}$ narrador reconhece a arbitrariedade final pela qual conseguiu evitar a ruptura definitiva com Ada, mas não reconhece a configuração inicial pela qual o casamento derivou da rivalidade edipiana com Giovanni, pois a repetição do desejo por Ada o impede de aceitar que poderia efetivamente preteri-la optando por uma das suas irmãs. Sem a relação edipiana com Giovanni, a visita na qual conheceu as suas filhas com o propósito de casar com uma delas se torna um completo mistério, fazendo com que o narrador introduza questionamentos acerca da sua incapacidade de justificar esse propósito. De fato, eles enquadram o relato da visita na qual conheceu as filhas de Giovanni. O questionamento presente no término do relato (2004, p. 704) é bastante direto e argumenta que haveria sido mais vantajoso para Zeno conhecer muitas mulheres antes de escolher uma noiva; as interrogações que perturbam o início do mesmo episódio, por sua vez, são mais elaboradas:

Quella prima visita io la ricordo come se l'avessi fatta ieri. Era um pomeriggio fosco e freddo d'autunno; e ricordo persino il sollievo che mi derivò dal liberarmi del soprabito nel tepore di quella casa. Stavo proprio per arrivare in porto. Ancora adesso sto ammirando tanta cecità che allora mi pareva chiaroveggenza. Correvo dietro alla salute, alla legittimità. Sta bene 
che in quell'iniziale $a$ erano racchiuse quattro fanciulle, ma tre di loro sarebbero state eliminate subito e in quanto alla quarta anch'essa avrebbe subito un esame severo. Giudice severissimo sarei stato. Ma intanto non avrei saputo dire le qualità che avrei domandate da lei e quelle che avrei abbominate. ${ }^{75}$ (2004, p. 694)

O narrador não consegue simplesmente contar a história vivida pelo protagonista, mas a interrompe com os seus questionamentos. Quanto ao início do parágrafo, é dominado pelas interrupções por meio do presente do narrador, chegando até mesmo a destacá-las ao fazê-las perturbar procedimentos narrativos tradicionais, como a dizer que não devemos esperar que tal maneira de narrar e a clara separação dos intervalos temporais que a caracteriza sejam levadas a sério nesse romance:

La prima frase, "Quella prima visita io la ricordo come se l'avessi fatta ieri",
- che in effetti istruisce il dibattimento interiore - sembra debba preparare a
un abbandonarsi al ricordo. La seconda, con un piglio dei più "narrativi"
secondo la tradizione del grande romanzo ottocentesco, "era un pomeriggio
fosco e freddo d'autunno", annuncia l'avvio di una storia; ma subito il ricorso
a un nuovo "io ricordo", al presente temporale e verbale, interrompe il
promesso slancio. (SAVELLI, 1998, p. 28)

Depois de as interrupções do presente do narrador impedirem que o relato seja completamente dedicado às recordações, o parágrafo finalmente cede espaço a sentenças cuja autoria é ambígua devido ao uso combinado do discurso indireto livre com tempos verbais apropriados - inicialmente o pretérito imperfeito e depois o futuro do pretérito. Trabalhemos com duas hipóteses principais para a autoria ambígua, das quais a primeira é que ela seja compartilhada entre o narrador e o protagonista, mas resultando em sentidos diferentes conforme se considere quem seja o autor dessas declarações.

No compartilhamento das sentenças em análise, os tempos verbais são usados de forma a confrontar temporalmente o narrador e o protagonista: este expressaria expectativas ou propósitos em relação ao seu futuro imediato, enquanto aquele os avalia quando esse futuro já se transformou em passado. Assim, em orações com verbos no futuro do pretérito no final do parágrafo citado, o protagonista expressa o seu propósito de escolher rigorosamente qual será a esposa, mas o narrador, mesmo sem expor o que

\footnotetext{
75 Recordo-me dessa primeira visita como se tivesse sido ontem. Era uma tarde acinzentada e fria de outono; recordo até mesmo a satisfação que me invadiu ao tirar o sobretudo na tepidez da sala. Sentia-me como se entrasse num porto seguro. Ainda agora me admiro da cegueira que então me parecia clarividência. Eu buscava a salvação, a honorabilidade. É certo que naquela inicial "A" estavam encerradas quatro moças; três delas seriam logo eliminadas e a quarta haveria de ser submetida a um exame severíssimo. Devo ter sido um juiz bastante rigoroso, embora não saiba descrever ao certo as qualidades que viria a exigir de minha futura esposa (2006, p. 75-76).
} 
efetivamente ocorrerá, avalia que ele não tinha nenhum critério para fazer a sua escolha. O cerne da postura do narrador está em que ele sabe dos resultados frustrantes a que chegaram as expectativas ou os propósitos do protagonista, o que é brevemente aludido pelo trecho "Ancora adesso sto ammirando tanta cecità che allora mi pareva chiaroveggenza". Logo, quando Zeno escreve "Stavo proprio per arrivare in porto", "Correvo dietro alla salute, alla legittimità" e "Giudice severissimo sarei stato", sem afastar a possibilidade de que ele próprio como narrador enuncie tais sentenças, é impossível evitar a ironia com que ele as enunciaria, na medida em que, se elas possuem alguma verdade, estão muito longe do sentido que realmente importa ao protagonista quando as enuncia, a saber, de que escolheria uma esposa para se casar, pois se casará com Augusta, a quem descartou como esposa na primeira vez que a viu.

A segunda hipótese principal para a autoria ambígua é que o único autor seja o narrador, o que seria possível se o protagonista, antes de conhecer Ada, só se interessasse pelo casamento como meio de colocar Giovanni ao alcance do seu ódio, dado que qualquer uma das filhas serviria a esse fim. Aliás, é justamente porque não pode errar em tal escolha, dada a sua arbitrariedade, que o protagonista pode se sentir tomado pela clarividência. O que talvez seja mais interessante nessa hipótese é que, após os dois períodos iniciais da citação, o tempo da história se reduziria unicamente ao sentimento de clarividência; todo o resto proviria do tempo da narração, a partir do qual se projetaria no protagonista a concepção do casamento como algo mais do que apenas um meio a serviço da rivalidade edipiana. Essa projeção também produz o interessante efeito de levar a função hipotética do futuro do pretérito ao extremo mesmo da irrealidade, pois nesse caso o protagonista jamais cogitara em ser um juiz que decide qual das filhas de Giovanni serviria para ser a sua esposa e que elabora critérios para auxiliá-lo em tal decisão.

Observemos também que o discurso indireto livre seria usado em ambas as hipóteses de modo diferente do que analisamos quando abordamos as repetições integralmente compartilhadas entre o protagonista e o narrador, pois expressa justamente uma divergência tal entre ambos que este se entrega à perplexidade frente à ação do protagonista.

Segundo a nossa proposta de leitura do romance, as duas hipóteses não são excludentes. A primeira é própria ao narrador, pois a repetição do seu desejo por Ada o impede de recuperar a repetição de rivalidade do protagonista contra Giovanni. A segunda se torna possível quando reconhecemos as repetições divergentes do recalcado 
e, como consequência de tal divergência, a deformação que a recorrência edipiana do narrador provoca sobre o relato produzido.

Para entendermos a segunda diferença entre o desejo edipiano do narrador por Ada e a situação do protagonista que funda intervenções divergentes no quinto capítulo, precisamos retomar a primeira mudança crucial do relacionamento de Zeno com Ada. Conforme já examinamos no capítulo anterior, essa relação inicia com um conflito entre as repetições da rivalidade contra o pai e do desejo pela mãe, ambas tendo a filha de Giovanni como substituta edipiana, e evolui para o fim do conflito com a permanência apenas da segunda repetição. De modo semelhante ao da primeira diferença, a narrativa é feita segundo a situação final, na qual o conflito já foi resolvido, o que falseia a história devido à deformação da rivalidade que está inicialmente presente na relação com Ada.

Consideramos que a ausência no narrador do conflito entre repetições do protagonista que envolvem Ada determine algumas das intervenções do narrador que se distribuem ao longo do relato do período inicial da relação de Zeno com ela, sendo que várias delas são acompanhadas pela referência à suposta intenção de se casar antes de conhecer as filhas de Giovanni, a qual já apresentamos na seção anterior do presente capítulo. Como exemplos de tais intervenções podemos mencionar um parágrafo (2004, p. 698) eivado de dúvidas sobre o comportamento do protagonista na sua relação com Ada - como a falta de uma paixão à primeira vista e a valorização de qualidades comuns entre ela e o pai dela como a seriedade e a energia - e de pretensas explicações que resolveriam essas dúvidas, como a busca da saúde e da higiene e as diferenças que haveria entre uma esposa e uma amante; os comentários de Zeno sobre a longa hesitação para se declarar à mulher que escolheu para ser a sua esposa (2004, p. 706707); e as explicações para as dificuldades do protagonista em cortejar Ada que Zeno elabora com base justamente na suposta intenção prévia de se casar (2004, p. 707-709).

No sexto capítulo, as principais intervenções divergentes do narrador estão fundadas na relação com as três mulheres principais da história: Ada, Augusta e Carla. Como examinamos no capítulo anterior, o personagem se esforça para manter um casamento aparentemente feliz dado que depende dele para manter alguma ligação com a mulher amada, o que afeta inclusive o seu desejo pela amante, pois recorrentemente age contra ele devido ao receio de que a esposa descubra a traição e acabe com o casamento. Para o narrador, Augusta não serve mais como ligação com Ada, de modo que está livre tanto para ser mais hostil do que o protagonista foi em algumas repetições 
de rivalidade contra a esposa e Vittorio Lali, o professor de canto que casa com Carla, quanto para lamentar as ações contra o desejo pela amante.

Quanto à relação conjugal, destaquemos duas repetições de rivalidade edipiana próprias ao narrador. $\mathrm{Na}$ primeira delas, ele não perde a oportunidade de destacar a implicação negativa de uma declaração do protagonista à amante de que estima muito a mulher:

C'era qualche centro proibitivo che agiva ancora in me. Avevo detto di stimare mia moglie, ma non avevo mica ancora detto di non amarla. [...] In quel momento mi pareva di essere molto sincero; ora so di aver tradito con quelle parole tutt'e due le donne e tutto l'amore, il mio e il loro. ${ }^{76}(2004, \mathrm{p}$. 836-837)

A mudança de opinião quanto à sinceridade da declaração se deve à alteração da situação de Zeno. Como protagonista, ele não pode negar o amor à esposa, pois depende dele para continuar ligado a Ada, o que justifica que considere sincero dizer que a estima, ainda mais porque é válido para as duas irmãs, que estão indissoluvelmentes ligadas para ele. Como narrador, não há mais tal dependência e a sinceridade estaria em romper a declaração conjunta a fim de negar que ama Augusta e afirmar o amor por Ada.

A segunda repetição de rivalidade própria ao narrador ocorre no início do capítulo, quando trata do que chama de saúde de Augusta. De fato, ele comenta (2004, p. 788) que, ao analisar a saúde da esposa, a converte em doença e começa a duvidar se semelhante saúde não necessitaria ser curada, apesar de que tal dúvida nunca lhe surgiu enquanto viveu com ela durante tantos anos. Também conclui que a esposa não sabia do que a saúde era feita, pois apenas os doentes analisam a si mesmos (2004, p. 793). Devido ao casamento com Augusta ser a única maneira de continuar ligado a Ada, Zeno precisou viver segundo a temporalidade burguesa da esposa. Apesar de se supreender com vários dos seus aspectos (2004, p. 786-788), o protagonista nunca questionou seriamente essa disposição temporal para manter o vínculo com a cunhada. É o narrador, para o qual o casamento já não tem a importância que tivera, que não consegue tratar disso sem aproveitar para exprimir as conclusões críticas sobre a concepção burguesa do tempo: ela seria incapaz de autoanálise e precisaria ser submetida a um tratamento. Logo, a compulsão repetitiva de Zeno é responsável pela dupla relação que ele estabelece com a temporalidade burguesa nos trechos que

\footnotetext{
${ }^{76}$ Havia um centro repressor qualquer que ainda agia em mim. Afirmei que estimava minha mulher, mas ainda não dissera que a amava. [...] Naquele momento pareceu-me estar sendo muito sincero; agora sei que traí com aquelas palavras ambas as mulheres e todo o amor, o meu e o delas (2006, p. 201).
} 
comentamos: o protagonista adere a ela apenas aparentemente, o que ressoa o efeito proporcionado pelos títulos dos capítulos e que já comentamos no presente capítulo, e o narrador lhe faz uma avaliação crítica tão severa que até se pergunta sobre a necessidade de erradicá-la - avaliação que só pode ser formulada por alguém alheio à saúde burguesa, devido à incapacidade desta para analisar a si própria.

No tocante aos lamentos pelas ações contra o desejo pela amante, o narrador é compelido a fazer o seu relato da relação extraconjugal ser pontuado por eles. Assim, no terceiro encontro com Carla, que é o primeiro na condição de amantes (o segundo encontro só consolida essa condição com o beijo que ocorre quando Zeno se despede), já é anunciado o fim dessa relação, e aparecem os lamentos do narrador de que se envergonha por haver amado Carla tão mal e de que só agora confia nela e aprecia a sua ingenuidade (2004, p. 834-837). Os lamentos em análise prosseguem em diversos momentos do relato do relacionamento com Carla, como os que derivam da simpatia que passou a reconhecer que ela merecia (2004, p. 870), da reprovação que parece ouvir ao lembrar uma das canções cantadas por ela $(2004$, p. 881$)$ e da sua falta de apoio à mulher que se entregou a uma aventura amorosa com ele (2004, p. 889). Destaquemos também, pelo fato de o narrador transferir uma situação que só ele pode cogitar para o protagonista, uma variação extrema da sua defesa do desejo pela amante segundo a qual troca a lamentação pela atitude de desafio a Ada:

Neppure adesso so esattamente perché io abbia presentata Ada a Carla quale
mia moglie. [...] Può avere influito sulla mia decisione anche la prudenza.
Avevo certamente ragione di temere gli umori della mia amante e se essa si
fosse lasciata trascinare a qualche atto inconsulto con Ada, ciò non avrebbe
avuto importanza visto che questa m'aveva già dato prova che mai avrebbe
tentato di diffamarmi presso mia moglie.
Se Carla m'avesse compromesso con Ada, a questa avrei raccontato tutto e
per dire il vero con una certa soddisfazione. ${ }^{77}(2004$, p. 890$)$

De fato, só o narrador, que não tem mais esperanças de conquistar Ada, pode cogitar que o protagonista revelaria a traição para ela, pois este age exatamente de modo inverso: procede recorrentemente contra o seu desejo por Carla justamente porque ainda almeja conquistar a cunhada.

Para encerrar as intervenções divergentes do narrador que nos propusemos

\footnotetext{
${ }^{77}$ Nem hoje sei por que desejei que Ada passasse aos olhos de Carla como sendo minha mulher. [...] Pode ter influído sobre a minha decisão até mesmo a prudência. Tinha certamente razão de temer os humores de minha amante e, se ela se deixasse levar a qualquer ato precipitado com Ada, isto não teria importância, já que esta me dera provas de que jamais tentaria difamar-me junto a minha verdadeira mulher.

Se Carla me comprometesse com Ada, eu haveria de contar-lhe tudo e, para dizer a verdade, com certa satisfação (2006, p. 248).
} 
abordar no caso do sexto capítulo, tratemos da diferença entre as situações de Zeno nos tempos da história e da narração em relação à hostilidade contra Lali: o protagonista precisava controlá-la como parte da necessidade de inibir os ciúmes para evitar que Carla decidisse abandonar as aulas com o professor de canto (2004, p. 882) ao passo que o narrador obviamente não tem mais necessidade de tal controle. Logo, são dele as principais hostilidades contra Lali:

Io non lo vidi mai, ma devo dire che oramai so molto di lui ed è una delle
persone che più stimo a questo mondo. Dev'essere un semplicione sano ciò
che è strano per un artista che viveva per la sua arte, come questo Vittorio
Lali. Insomma un uomo invidiabile, perché geniale e anche sano.
[...] Cantavano [Carla e Lali] ora insieme delle canzoni sue che mi parvero
povera cosa tanto quando amavo Carla quanto allorché la sentivo come una
catena. Può tuttavia essere che fossero buone ad onta che io poi non ne abbia
più sentito a parlare. Egli diresse poi delle orchestre negli Stati Uniti e forse
colà si cantano anche quelle canzoni. ${ }^{78}$ (2004, p. $\left.880-883\right)$

Esses trechos (o segundo deles é o mesmo analisado por Savelli nas citações que fizemos dele no início da primeira seção do presente capítulo) são repetições de uma das características da rivalidade edipiana de Zeno, a competição com o rival em alguma área que lhe seja própria, a qual comentamos no capítulo anterior, apenas para o protagonista, como a oitava característica do componente paterno do recalque edipiano de Zeno. No caso de Lali, essa disputa assume a forma de uma avaliação da sua capacidade artística, na qual o narrador a questiona de algumas maneiras e inclusive tenta fazê-lo de modo a escapar de um julgamento pessoal apelando à noção romântica de gênio, segundo a qual a grandeza artística estaria associada à doença e à loucura, à independência em relação aos ciúmes que sente por Carla e aos critérios impessoais de sucesso junto ao público (mesmo no caso do sucesso meramente hipotético em outro país, ele não haveria sido o suficiente para uma repercussão internacional) e na carreira profissional, pelo qual fica subtendido que o posto de regente no país norte-americano resultaria do fracasso em conseguir o mesmo posto nos países efetivamente importantes para a arte da música na época de Zeno.

Por fim, abordemos a principal diferença entre as situações de Zeno como protagonista e narrador no último capítulo da autobiografia analisando um trecho no

\footnotetext{
${ }^{78}$ Nunca cheguei a vê-lo, mas devo afirmar que agora sei muito a respeito dele, e é uma das pessoas que mais estimo neste mundo. Devia ser uma dessas criaturas simplórias, o que é estranho para um artista que vivia de sua arte, esse Vittorio Lali. Em suma, um homem de se invejar, pois que, além de genial, era também saudável.

[...] Cantavam [Carla e Lali] canções de sua autoria, que achei bastante chochas, fosse quando Carla me inspirava amor, fosse quando me parecia um trambolho. Pode ser, contudo, que fossem boas, ainda que nunca ouvisse depois falarem delas. O homem foi mais tarde reger orquestras nos Estados Unidos e talvez por lá até cantem essas canções (2006, p. 240-242).
} 
qual o segundo começa expondo a própria incapacidade para explicar a razão pela qual permaneceu dois anos associado a Guido e termina lamentando o vazio da sua vida após o fim do grande afeto pelo concunhado, ainda que esse afeto, convenientemente, não seja melhor identificado (2004, p. 912-913). Toda a ação do protagonista enquanto ele trabalhou com Guido foi baseada na articulação entre as suas relações edipianas com Ada e o concunhado; mais precisamente, Zeno se dedicou a promover secretamente o fracasso do rival aos olhos da esposa para que o casamento deles fosse abalado a ponto de que pudesse tentar satisfazer o desejo pela cunhada. $\mathrm{O}$ narrador manteve as relações do protagonista com ambos os parentes, mas a articulação entre elas simplesmente se desfez desde o momento no qual Ada revelou que entendeu que Zeno odiava o seu marido (2004, p. 1042-1045).

A diferença que expusemos no parágrafo anterior nos permite considerar que o sucinto resumo que fizemos sobre o trecho em análise do romance derive de que Zeno, ao narrar a associação com Guido, reaja à relação com o concunhado como se ela não estivesse articulada ao desejo por Ada. Há duas reações conflitantes, as quais diferem pelo elemento da compulsão repetitiva do narrador que envolvem. O primeiro elemento é a repetição da própria rivalidade contra Guido, que impede que Zeno simplesmente relate que permaneceu submisso a um rival durante vários meses, ainda mais no contexto da administração de um negócio, que é um objeto privilegiado da competição comercial que caracteriza a sua rivalidade edipiana, de modo que interrompe o relato para questionar com firmeza o fato de haver trabalhado na empresa do concunhado. $\mathrm{O}$ segundo elemento é o tédio da temporalidade da nota única, na qual Zeno geralmente se encontra desde a partida de Ada após o suicídio do marido, já que nunca mais estabeleceu ligações edipianas que fossem duradouras segundo o que registrou na autobiografia. Dada a ausência de repetições regulares, o narrador até mesmo apresenta a relação com Guido como desejável por si própria por meio da referência ao afeto entre eles, em franca contraposição ao questionamento que comentamos; para o protagonista, porém, a submissão ao concunhado só é possível por estar vinculada ao desejo por Ada.

Uma vez que abordamos as intervenções divergentes do narrador estudando as suas principais ocorrências ao longo da autobiografia de Zeno, investiguemos como opera o segundo tipo de repetições divergentes, aquelas que alteram a própria escrita autobiográfica, como no último dos casos do segundo grupo de repetições. Nesse tipo, as recorrências edipianas do narrador são decisivas para a constituição do tempo da narrativa, além de poderem gerar distorções em graus variados no tempo da história. 
Como material para a nossa investigação, usemos dois exemplos de tais repetições divergentes.

O primeiro exemplo que investigaremos é a peculiar composição do quarto capítulo, que está associada a uma alegada divisão da vida do protagonista. Comecemos por essa alegação, que consiste em Zeno considerar que a morte do seu pai era uma grande catástrofe segundo a qual a vida anterior a esse evento era a sua parte mais importante e decisiva e a posterior seria esvaziada de propósitos devido à ausência de objeto para eles (2004, p. 654). O narrador precede a exposição dessa consideração do protagonista pela seguinte formulação sobre o mesmo evento: “" 15.4 .1890 ore 4 1/2. Muore mio padre. U. S. [último cigarro]'. [...] Nessuno lo crederebbe, ma, ad onta di quella forma, quell'annotazione registra l'avvenimento più importante della mia vita"79 (2004, p. 653).

A qualificação que o narrador atribui à morte do primeiro rival edipiano ratifica a função crucial exercida por esse evento na divisão sugerida pelo protagonista, mas introduz uma diferença sutil e decisiva ao atribuir importância antes ao falecimento em si do que à vida anterior a ele. Como vestígio adicional da introdução de um elemento próprio ao narrador nessa qualificação, propomos que a sua formulação textual favorece a hipótese de que ela seja mais uma apropriação resultante da leitura feita por Zeno de um tratado psicanalítico (talvez tal empréstimo sirva justamente como o principal indício para identificar esse livro), dado que Freud usou tal formulação na seguinte consideração autobiográfica de um de seus livros mais célebres, dedicado à interpretação dos sonhos:

Pois este livro tem para mim, pessoalmente, outra importância subjetiva uma importância que só apreendi após tê-lo concluído. Ele foi, como verifiquei, parte de minha própria autoanálise, minha reação à morte de meu pai - isto é, ao evento mais importante, à perda mais pungente da vida de um homem. (1987a, p. 32)

$\mathrm{Na}$ época da morte do pai, o protagonista valorizava ao máximo a vida pregressa a tal evento porque ela foi provida de duradouras relações edipianas, sendo que a mais longeva foi a rivalidade contra o pai, e porque esse falecimento introduziu a temporalidade da nota única na sua vida; o narrador, por sua vez, valoriza bem menos essa relação geral de rivalidade porque já teve substitutos duradouros para o pai no que tange a ela, e, portanto, as repetições que se impõem ao narrador no que se refere ao

\footnotetext{
79 "15.4.1890, às 4 e 30. Meu pai morreu. U.S. [último cigarro]" [...] Ninguém acreditaria mas, malgrado aquela forma, essa anotação registra o acontecimento mais importante de minha vida (2006, p. 39).
} 
progenitor estão ligadas ao conflito entre o desejo de que o rival morresse e a derrota que este infligiria a Zeno pela entrada em vigor do testamento, pois o fim do rival não resolveu o conflito, o qual permanece operante inclusive para o narrador. Tal divergência justifica a mudança que mencionamos do que Zeno considera mais importante na própria vida.

A divergência que examinamos ganha toda a sua relevância na peculiar composição do quarto capítulo. Ofereçamos uma primeira e breve aproximação a essa questão expondo o conflito básico do tema do trecho narrativo em análise. Segundo o seu título, o tema do quarto capítulo seria a morte do pai, mas o primeiro parágrafo já menciona a biografia desse personagem, restringida apenas ao critério de que os momentos relatados sirvam para reavivar as recordações de Zeno sobre si próprio (2004, p. 653); de fato, há mais de dez parágrafos dedicados à vida mesma do pai e à convivência com Zeno anteriores a qualquer indício relacionado à morte paterna (2004, p. 654-657).

Uma vez que expusemos o conflito básico do tema do quarto capítulo, estudemos a sua relação com a composição do quarto capítulo por meio dos seguintes aspectos temporais: a ordem temporal, a condução das expectativas, a velocidade da narrativa e a causalidade.

Comecemos abordando a ordem temporal e a condução das expectativas. Como um dos temas trata do pai ainda vivo e o outro, da sua morte, obviamente eles estão separados cronologicamente. Em termos de blocos temáticos, o capítulo está dividido em três, dos quais o primeiro (2004, p. 653-654) e o terceiro (2004, p. 657-684) são dedicados ao tema da morte paterna e o segundo aborda o tema cronologicamente anterior. Além disso, o bloco inicial trata das consequências do falecimento, o que encerraria o capítulo se ele seguisse a cronologia, de modo que ele instaura uma radical inversão em relação ao tempo da história.

Reconsiderando os blocos temáticos em termos de como as expectativas são conduzidas, observamos que o primeiro deles se associa ao título para direcioná-las decisivamente para a morte do pai, mas esse direcionamento inicial é abruptamente interrompido pelo bloco intermediário, para o qual o narrador não elabora uma condução definida das expectativas. Por fim, o direcionamento inicial dado a elas finalmente é atendido no último bloco, no qual efetivamente é relatada a morte paterna.

Logo, a peculiar composição do quarto capítulo enfatiza sobremaneira a morte do pai, pois o título e o início direcionam todo o horizonte da narrativa para esse 
acontecimento -inclusive porque o começo o apresenta caracterizado pelo protagonista e pelo narrador, conforme já comentamos, como sendo aquele que divide a vida de Zeno em duas partes -, e o bloco final responde ao direcionamento inicial. Isso provoca tal deformação na importância relativa a ser dada aos eventos narrados a ponto de os leitores tenderem a considerar que o bloco intermediário do capítulo retarda a narrativa do que realmente interessa.

Em suma, o que é mais importante para o narrador se torna o tema efetivo do capítulo ao passo que o tema das repetições, que importam muito mais ao protagonista do que ao narrador, fica relegado a uma condição periférica, como se fosse uma perturbação para a elaboração do tema efetivo. O contraste no tratamento temporal dado aos dois blocos finais do capítulo reforça essa conclusão, como podemos verificar considerando a ordem temporal e a causalidade. Segundo ambos os aspectos, o bloco intermediário está fracamente articulado - uma acumulação de relatos sobre a relação com o pai na qual a ordem e a datação dos eventos e as conexões causais entre eles são mal estabelecidas (ou nem mesmo há indícios para estabelecê-las) - ao passo que o último bloco possui uma nítida progressão cronológica e causal: o episódio do testamento, as manifestações da doença fatal e finalmente a morte e o enterro do pai.

Por fim, há um claro contraste na velocidade da narrativa dos dois blocos finais, o qual também reforça a nossa conclusão. Esses blocos preenchem trinta e uma páginas na edição que usamos para o presente trabalho. Os relatos sobre a vida do pai abrangem vários anos e ocupam apenas quatro dessas páginas ao passo que o episódio da crise final da doença do pai, no qual efetivamente a iminência da sua morte domina o texto, abrange uns quinze dias (LAVAGETTO, 1975, p. 79) e ocupa vinte e seis páginas.

O segundo exemplo que investigaremos de repetições divergentes que alteram a própria escrita autobiográfica são as inversões cronológicas do início do quinto capítulo. Conforme comentamos no primeiro capítulo deste trabalho, essa manipulação temporal é uma técnica de distorção de conteúdos recalcados que Freud destacou ao estudar os sonhos.

$\mathrm{Na}$ seção anterior do presente capítulo, já abordamos, ainda que implicitamente, uma das inversões cronológicas em questão: na própria história autobiográfica de Zeno, estão invertidos a ideia de se casar e o fato de conhecer Giovanni. Consideramos que se trata novamente da repetição do desejo por Ada que impede o narrador de aceitar que poderia efetivamente preteri-la optando por uma das 
suas irmãs, como fez na condição de protagonista antes de conhecê-la, conforme argumentamos ao tratar das intervenções divergentes do narrador no quinto capítulo. De acordo com a nossa proposta, por recusar que poderia preterir Ada, o narrador também recusaria a causa da indiferença dessa escolha apresentando o propósito de casar como superação do tédio no qual vivia após a morte do pai. De fato, ao oferecer uma justificativa supostamente racional, qualquer que seja, para se casar, Zeno recupera a suposta normalidade da sua conduta e, portanto, a exigência de escolher a futura cônjuge, desautorizando que se cogite que Ada pudesse ser preterida pelo protagonista.

Além da inversão supra, interna à própria diegese, há também inversão do tempo da narrativa em relação ao da história quando Zeno relata que conheceu Giovanni antes de narrar a ida à bolsa de valores de Trieste, onde conheceu o futuro sogro (2004, p. 686). Propomos que essa disposição narrativa seja mais um dos elementos de um processo de divergência, em grande medida, equivalente àquele do conflito temático que exploramos no caso do quarto capítulo: a repetição da rivalidade edipiana com o sogro deixou de ser importante para Zeno após a morte do rival (neste caso, o protagonista já tinha até um rival mais importante, Guido), de modo que o mais importante na relação do narrador com Giovanni é outra repetição edipiana, a do desejo por Ada. Em favor da nossa linha de análise, podemos recorrer à notável semelhança no tratamento dado ao bloco do quarto capítulo sobre o pai ainda vivo e ao trecho dedicado à relação entre Zeno e Giovanni (2004, p. 686-692), baseada no interesse de ambos pelo comércio, pois esse trecho é uma acumulação de relatos de fraca articulação narrativa e fica isolado na parte interna de um capítulo que é dedicado, inclusive no seu título, à história do casamento. Ao ser constituído de modo invertido, o trecho em análise está de acordo com essa divergência, na medida em que principia pelas referências ao futuro sogro, prossegue apresentando o seu nome e a sua descrição e apenas então relata como conheceu Giovanni.

Em suma, o resultado da dupla inversão devida às divergências repetitivas entre o narrador e o protagonista é que os três momentos em análise da história de Zeno estão cronologicamente invertidos na narrativa: a ideia de casar é apresentada antes dos relatos iniciais sobre Giovanni, que são anteriores à exposição do primeiro encontro com o futuro sogro.

Com base na investigação que fizemos da operação do narrador segundo a compulsão à repetição do recalcado, a nossa conclusão é de que a constituição do narrador, justamente pelo seu desempenho na produção da autobiografia, é tão 
determinada por tal compulsão quanto estabelecemos para o protagonista. Logo, consideramos a autobiografia de Zeno como sendo constituída por duas grandes séries repetitivas, as do protagonista e do narrador, que são temporalmente distintas, mas se encontram justamente na elaboração da narrativa. Assim, não acompanhamos simplesmente a sucessão das mudanças nas interferências entre as repetições do protagonista, que analisamos minuciosamente no capítulo anterior deste trabalho, pois há uma interferência mútua entre as repetições do narrador e o relato do comportamento repetitivo do personagem que faz com que o texto tenda a se distanciar em alguma medida da experiência vivida por Zeno no tempo da história para oferecer a experiência que ele tem de recordá-la e narrá-la ao se preparar para uma terapia psicanalítica, o que inclui a diegese em variados graus de distorção.

Os casos de distorção mínima da diegese são os de convergência entre as duas séries repetitivas, exceto quando a recorrência do narrador incorpora algum elemento alheio ao momento em questão da história sem lhe dar um tratamento transparente. Tais casos realçam a natureza repetitiva da conduta de Zeno ao assinalar uma permanência entre o protagonista e o narrador apesar dos muitos anos que os separam. Nas demais repetições do narrador, encontramos os mais variados fenômenos de distorção: quanto ao tempo da história, elas podem incluir detalhes que retomam uma repetição que está sendo narrada ou causar uma inversão cronológica; no tocante ao tempo da narrativa, elas podem moldá-lo conforme a importância distinta que concedem a dois momentos da história ou simplesmente causar um desvio da cronologia; e, no que se refere ao tempo de narração, elas podem permeá-lo com lamentos e dúvidas devidos às divergências em relação ao regime repetitivo do protagonista. Essa variada produção de distorções dificulta a compreensão de aspectos importantes do texto, o que torna relevante a investigação das repetições que estão operando em cada uma das duas instâncias narrativas, conforme fizemos com os trechos analisados na presente seção.

Como resultado da nossa investigação, consideramos que tanto a intríseca tendência da compulsão repetitiva a não reconhecer o recalcado nem as repetições que ele constitui quanto a profusão das distorções que destacamos no parágrafo anterior dificultam de tal modo a identificação das repetições do protagonista e do narrador que se torna muito fácil reduzir a incomum complexidade temporal do romance às perturbações da cronologia e à multiplicação de intervalos temporais cujo entrelaçamento subjetivo seria de natureza pouco determinada. Foi como um embate entre as temporalidades linear e de onda que abordamos, nas duas primeiras seções, esse 
âmbito temporal da autobiografia que desconsidera em grande medida as recorrências que a compõem. Na próxima seção, explicitaremos as maneiras pelas quais essas temporalidades estão articuladas.

Além disso, ainda precisamos analisar outros fatores relevantes para a constituição temporal do romance. No que tange à autobiografia, procederemos a essa análise na última parte da próxima seção. No tocante à totalidade do romance, obviamente devemos incluir os fatores que são nitidamente mobilizados apenas no último capítulo e, portanto, trataremos dos mesmos no capítulo seguinte do presente trabalho.

3.5. A configuração temporal da autobiografia de Zeno como superação do âmbito da sua experiência manifesta: as articulações da compulsão à repetição do recalcado com as temporalidades linear e de onda

Dedicaremos a presente seção a investigar as articulações que a compulsão à repetição do recalcado estabelece com as temporalidades linear e de onda na autobiografia de Zeno, as críticas contundentes que são implicadas por tais articulações e a mudança sofrida por tal esquema articulatório na transição do terceiro capítulo para os demais.

A fim de começarmos a entender como se articulam as temporalidades que identificamos na autobiografia de Zeno, recorramos a elementos cruciais da sua construção que são introduzidos no preâmbulo e nos dois primeiros capítulos autobiográficos. Da nossa análise do capítulo preparatório e dos parágrafos de abertura do próximo, retomemos os seguintes resultados: a rejeição da valorização psicanalítica do presente e da recuperação do passado segundo uma temporalidade cronologicamente invertida. Por um lado, o narrador recusou a recomendação do doutor S. para valorizar o presente; por outro lado, acatou plenamente outra orientação do psicanalista, a de iniciar a autobiografia pela análise histórica da sua propensão ao fumo (2004, p. 628). De fato, a escrita autobiográfica de Zeno inicia desenvolvendo cronologicamente um determinado tema, apesar de todas as limitações que já expusemos nas duas primeiras seções deste capítulo. A partir dessa divergência na recepção pelo narrador das abordagens recomendadas pelo doutor S., investiguemos como o próprio preâmbulo 
fornece um valioso material para comparação entre as duas abordagens: a imagem da locomotiva.

Como comentamos ao analisar o preâmbulo, a locomotiva seria a primeira associação que poderia desencadear a sequência cronologicamente invertida de recordações traumáticas de Zeno, pois o resfolegar desse veículo remete à respiração barulhenta do pai moribundo (2004, p. 669). A partir das reações ambíguas do protagonista à iminente morte paterna, talvez fosse possível recuperar as relações de rivalidade com o pai e com o irmão e, por fim, o desejo pela mãe; porém, tal possibilidade é afastada quando o narrador descarta a imagem da locomotiva antes mesmo de entendê-la e, portanto, abandona a valorização psicanalítica do presente. Aceitando a recomendação de uma abordagem histórica do vício tabagista, Zeno inicia a autobiografia a partir do começo do vício com o irmão na escola sem as recordações traumáticas necessárias para compreendê-la. Tal começo é posterior ao que seria o próximo elemento da sequência clínica (conforme a primeira visão obtida no tratamento com o doutor S.), que remete aos primeiros anos na escola, quando o irmão ainda fica em casa (2004, p. 1051-1052).

Quanto à morte do pai, a qual deveria haver sido o ponto de partida das recordações, ela só será alcançada no quarto capítulo, quando finalmente o narrador entende que a locomotiva está associada a esse evento, mas já é muito tarde, pois os principais acontecimentos traumáticos que essa associação deveria ajudar a recuperar foram relegados a um passado anterior ao próprio início da autobiografia e não serão mais buscados numa narrativa concebida cronologicamente. Mesmo os momentos anteriores ao pai morrer foram relatados sem a perspectiva aberta pela compreensão de tal associação e não serão retomados à luz dessa descoberta justamente por causa da ordenação cronológica que o narrador adota. Por meio dessas considerações, a tensão de uma locomotiva resfolegante segundo as duas direções contrárias que os trilhos the permitem - a progressão de uma subida com extrema dificuldade de uma encosta ou a regressão de uma descida que conduziria a um precipício - cessa de expressar apenas a associação própria ao enredo da difícil luta do pai contra a morte para poder também comportar um significado atrelado à própria situação da escrita de Zeno: a oposição entre insistir com a narrativa cronológica, apesar das dificuldades que resultam no fracasso em impor uma temporalidade linear ao texto, e suspender o controle consciente em favor de uma atitude de entrega que propicie a inversão temporal das recordações traumáticas em direção ao "precipício" do que foi recalcado. 
Com base na escolha do narrador entre as duas recomendações do doutor S. para a escrita autobiográfica e na nossa análise da locomotiva imaginada por ele, consideramos que a principal articulação entre a temporalidade linear e a compulsão à repetição do recalcado é a eficiência da primeira em evitar o reconhecimento do que foi recalcado, uma atitude que é inerente à própria noção de recalque, por ser inversa à ordem temporal capaz de superar o recalque, a qual inicia nos pensamentos atuais e opera regredindo para conteúdos recalcados cada vez mais antigos. Sem que as recordações traumáticas surjam, o paciente não conhece devidamente a vida pregressa ao momento ao qual remete a primeira recordação e, portanto, tampouco adquire o conhecimento correspondente sobre a sua vida após esse dia. Assim, Zeno permanece sem o devido conhecimento sobre a própria história e até mesmo declara mais de uma vez a sua incapacidade de entendê-la, como destacamos no início do segundo capítulo. Desse modo, a ignorância de Zeno abrange, antes de mais nada, o recalcado e, portanto, que ele esteja constantemente sendo repitido. De fato, tal como o protagonista, o narrador também é geralmente incapaz de reconhecer a presença da repetição na sua vida.

Além da oposição entre as recomendações recusada e aceita pelo narrador, há outro fator para a articulação que propomos entre a temporalidade linear e a repetição do recalcado, o qual deriva da relação direta entre os tempos da história e da narrativa: como o relato replica a ordem na qual os acontecimentos se deram, há uma trivial propensão a uma atitude de pouco questionamento sobre a transição entre os eventos e à instalação de um regime de continuidade no qual um certo automatismo faz o foco da nossa atenção se deslocar para o próximo acontecimento. Tais efeitos ainda são amplificados pela causalidade virtual da sequência narrativa, que expusemos no primeiro capítulo e exemplificamos ao tratar da causalidade na segunda seção deste capítulo. A pouca atenção dispensada às conexões entre os eventos é de extremo proveito no contexto da repetição do recalcado, no qual a incapacidade intrínseca de reconhecimento do que foi recalcado gera conexões inexistentes ou insubsistentes em abundância, pois faz com que várias delas nem mesmo sejam percebidas ou sejam displicentemente desconsideradas por supostamente não serem importantes.

Além da ordenação cronológica da narrativa, outro elemento de constituição da temporalidade linear na autobiografia de Zeno é o modelo da vida burguesa, o qual já é adotado em grande medida na conduta aparente do protagonista e é reforçado pelo narrador, seja pelo ocultamento do vínculo do casamento com a rivalidade contra 
Giovanni, seja pela divisão em capítulos conforme etapas compatíveis com o paradigma burguês. Esse modelo está relacionado com a repetição do recalcado de modo semelhante ao que expusemos no caso da cronologia narrativa, pois também propicia a instalação generalizada de uma orientação temporal direcionada para o futuro e de uma dissimulação da fragilidade causal da sequência de eventos. Além dessa base comum, também devemos destacar dois aspectos da relação em análise que são contribuições adicionais para a construção aparente da autobiografia segundo uma temporalidade linear e, portanto, para dificultar o reconhecimento da temporalidade repetitiva que constitui a história e a escrita de Zeno. Por ser um paradigma socialmente reconhecido, a orientação burguesa para o futuro também abarca o conteúdo dos momentos futuros, de modo que também propicia um esquema geral, ainda que frágil no caso de Zeno, de condução de expectativas. No tocante à causalidade, a contribuição do modelo burguês é grande, pois introduz a pressuposição generalizada de uma causa, a da adesão à norma social.

Em suma, consideramos que a adoção da temporalidade linear na autobiografia - por meio tanto da abordagem cronológica da narrativa quanto da propalada adesão do protagonista e do narrador ao modelo da vida burguesa - está, antes de mais nada, em conformidade com a repetição do recalcado de Zeno por justamente operar no sentido de dificultar o reconhecimento dos conteúdos submetidos ao recalque, inclusive a compulsão a repeti-los.

Uma vez que analisamos a articulação entre a linearidade temporal e a repetição do recalcado, introduzamos a temporalidade de onda na nossa investigação. Dividiremos a nossa tarefa em duas partes, cada uma delas abordando uma das principais articulações entre essas três temporalidades.

Como já examinamos na segunda seção, a temporalidade de onda na autobiografia de Zeno implica o fracasso da temporalidade linear que o narrador tenta impor ao texto. Isso vale para as duas articulações que exporemos, de modo que o fator crucial para diferenciá-las é a relação dessas duas temporalidades com a repetição do recalcado.

A primeira das articulações em análise é a mais abrangente, pois é intrínseca à própria constituição da temporalidade linear a partir da repetição do recalcado, cujo estudo foi o principal objeto do início da presente seção. De fato, como o tratamento linear do tempo é adotado para dificultar o reconhecimento do recalcado e das suas repetições, o próprio sucesso desse objetivo impede a reconstituição das conexões 
causais entre os eventos e das expectativas efetivas, a qual permitiria o estabelecimento exitoso dessa configuração temporal.

Logo, a autobiografia de Zeno falha com muita frequência no encadeamento por causas efetivas e na codificação hermenêutica, o que provoca a impressão geral de uma sucessão casual de eventos. Ora, foi justamente por essa debilidade na constituição do fluxo linear do tempo que caracterizamos a temporalidade de onda no final da segunda seção. Acrescentemos apenas que essa debilidade pode até mesmo perturbar a cronologia da narrativa, já que tal falta de ligações entre os eventos pode tornar irrelevante a ordem na qual ocorreram e até mesmo a sua datação; por exemplo, podemos observar o descuido no tratamento das posições temporais tanto na imprecisão dessa posição em eventos pertecentes a uma sequência cronológica bem definida quanto na indeterminação temporal dos acontecimentos dentro de períodos de décadas.

A segunda articulação entre as temporalidades linear, de repetição do recalcado e de onda consiste na relação direta entre as duas últimas, ou seja, sem a intermediação da linearidade temporal, que é crucial na articulação anterior. Um caso de poucas ocorrências dessa configuração é interno ao tempo da história: o próprio protagonista apela a uma figura de negação da causalidade como uma distração que retire a atenção da natureza repetitiva de uma das suas ações ou de um dos seus hábitos. Os principais exemplos desse caso são dois componentes da história de Zeno que já comentamos no presente capítulo. São eles a relação supersticiosa dos "últimos" cigarros baseados com as motivações externas, principalmente as relações numéricas das datas, e a ideia de originalidade da vida, que surge justamente num passeio noturno de Guido e Zeno no qual ambos recordam um passeio muito semelhante que fizeram quando se conheceram.

Muito mais abrangente na autobiografia de Zeno é a temporalidade de onda que é causada pelo simples fato de que o narrador também participa da repetição do recalcado. Isso ocorre tanto com as repetições convergentes quanto com as divergentes que expusemos na seção anterior. A presença frequente de ambos os tipos tende a interromper o fluxo temporal da história pelas intervenções no presente do narrador e pela introdução dos elementos alheios ao contexto da história e, como as repetições tendem a não ser reconhecidas, elas contribuem para o agravamento da debilidade da causalidade e da condução de expectativas no texto; inclusive, ímpetos explicativos causados por recorrências do narrador podem enfraquecer a causalidade como nos casos das explicações discordantes sobre o cigarro e o das tentativas desarticuladas de julgar a capacidade artística de Lali. 
As prolepses de algum fato crucial da história de cada capítulo da autobiografia, que apresentamos na primeira seção, também são causadas pelas repetições do narrador: uma das suas explicações sobre o cigarro está baseada em ele ainda sofrer com o distúrbio dos "últimos" cigarros; as antecipações da morte do pai e de aspectos da relação com Carla são efeitos das repetições divergentes referentes a esses personagens e que abordamos na seção anterior; e o desejo por Ada é a causa para que o narrador indiretamente lamente o fracasso em conquistá-la na primeira oportunidade de que dispõe nos capítulos quinto e sétimo, ao mencionar respectivamente um episódio com Giovanni que ocorreu nas núpcias de Ada e o fato de que a sua atividade na empresa de Guido não the deu nenhum fruto, ou seja, não permitiu que conquistasse a cunhada apesar da vitória sobre o concunhado.

As repetições divergentes contribuem de modos específicos para causar a temporalidade de onda. Quando a divergência entre o protagonista e o narrador não é explícita, ela pode produzir uma versão alternativa à da história do protagonista que é tão ou mais frágil em termos de causalidade ou condução de expectativas do que a versão substituída. Consideramos que esse seja o caso da inversão cronológica entre Zeno conhecer Giovanni e decidir se casar, o que faz o narrador recorrer a algumas figuras do acaso, as quais comentamos na primeira seção.

Quando o narrador explicita a sua divergência com as ações do protagonista, ele acrescenta ao emaranhado de possibilidades promovidas pelo protagonista a respeito do seu comportamento - como estudamos no capítulo anterior, o comportamento edipiano do personagem é composto por repetições simultâneas que interferem entre si e que geralmente nem mesmo são reconhecidas como sendo recorrências - novas perspectivas ao modo como o personagem agiu, seja implicitamente com o reconhecimento de que não sabe a razão dessa ação ou simplesmente por atribuí-la ao acaso, seja explicitando a ação alternativa, como acontece ao lamentar pelo que não fez ou ao promover hostilidades que tampouco cometeu.

Quanto mais se torna explícita a divergência entre o narrador e o protagonista, mais é desestabilizada a própria história, pois as alternativas trazidas pelo tempo da narração são embasadas de modo tão frágil quanto as próprias ações do protagonista. Ao trazer para a história novas perspectivas que não produzem a versão derradeira mas sim alternativas àquela versão que seria simplesmente a da vivência do protagonista, o narrador deixa a história num estado de indeterminação, dado que nada assinala que novas perspectivas não possam ser introduzidas do mesmo modo como as anteriores o 
foram. O resultado temporal dessa indeterminação é, mais uma vez, a temporalidade de onda.

Observemos que as nossas considerações ampliam o contraste com Proust que fizemos no final da segunda seção. De fato, a desestabilização da história pela produção de alternativas àquela versão que seria simplesmente a da vivência do protagonista aprofunda a ausência de recuperação retrospectiva das deficiências da temporalidade linear. Assim como a própria narrativa não se encaminhou por si mesma para um maior esclarecimento da história, o narrador ainda aumenta a necessidade de esclarecimento com as suas repetições divergentes que desestabilizam a própria história que tenta relatar.

Uma vez que finalizamos o estudo de como estão articuladas as temporalidades que identificamos na autobiografia de Zeno, estamos preparados para abordar as críticas tácitas mas contundentes que são implicadas por tais articulações a convenções literárias e sociais que eram hegemônicas na época de Svevo: a temporalidade linear da narrativa clássica e a concepção burguesa da vida. Baseamos a nossa apreciação no fracasso que, mais cedo ou mais tarde, infalivelmente arremata as incansáveis tentativas tanto de Zeno, como protagonista e narrador, de conceber as próprias ações dentro das etapas burguesas da vida quanto do narrador de escrever a autobiografia segundo a temporalidade linear. O reiterado e previsível fracasso termina por expor ao ridículo as próprias convenções que Zeno insiste em impor à história e à narrativa, o que ainda é reforçado pelo humor irônico que frequentemente acompanha tais tentativas frustradas.

Ainda precisamos identificar o que exatamente seria criticado na temporalidade linear e na concepção burguesa da vida. Ambas instauram uma progressão do passado para o futuro cujos eventos sucessivos estão ligados por relações de causa e efeito, o que dificulta o reconhecimento de padrões repetitivos, desconsidera a importância das associações livres de ideias por focar na causalidade entre os eventos que se sucedem e inviabilizam a adoção da temporalidade invertida para a recuperação das recordações patogênicas. Além disso, as etapas burguesas estabelecem um conteúdo básico para a sucessão temporal que serve de material para produzir distorções para o comportamento repetitivo de Zeno e reforça ainda mais a desconsideração das associações livres, dado que alguns dos eventos principais e as suas ligações de causa e efeito estão supostamente asseguradas pelas normas inerentes à sociedade burguesa.

Em suma, ao menos no caso de Zeno e de todos os que estão submetidos à compulsão da repetição do recalcado, a temporalidade linear e a concepção burguesa da 
vida são fatores de alienação do sujeito na medida em que operam no sentido de impedir que ele elabore um conhecimento efetivo sobre si mesmo por dificultarem o reconhecimento dessa repetição. Podemos nos perguntar se a crítica à alienação burguesa ficaria restrita às vítimas dessa psicopatologia. Apresentaremos indícios que sustentam uma resposta negativa a essa questão no final do próximo capítulo, no qual abordaremos o final do romance, o qual nos fornecerá o material necessário para os referidos indícios.

Uma vez que expusemos quais são as articulações elaboradas entre as principais temporalidades da autobiografia, estamos em condições de fazer uma breve avaliação da mudança sofrida por tal esquema articulatório na transição do terceiro capítulo para os demais: apesar das articulações que expusemos serem válidas para todos eles, elas apresentam uma variação importante ao considerarmos separadamente cada uma das duas partes autobiográficas. Iniciando pela primeira dessas partes, tratemos de tal variação analisando como ela é constituída com base nos principais elementos específicos do tempo da narração no presente caso, que são o tratamento com o doutor S. e a própria escrita da autobiografia, a começar pela recomendação do psicanalista que é acatada pelo narrador para a sua escrita.

Como já assinalamos na presente seção, a recomendação do doutor S. que é acatada pelo narrador é a de iniciar a autobiografia pela análise histórica da sua propensão ao fumo. Com base na escrita dedicada a um tema e, especificamente, ao vício tabagista, podemos compreender a situação peculiar que o terceiro capítulo possui na autobiografia.

Abordemos inicialmente o componente mais geral da recomendação em questão, o da silepse temática. Como o doutor S. também recomenda que Zeno faça uma análise histórica, a temporalidade linear da narrativa não é simplesmente descartada, mas ela é submetida a um tratamento temático, cuja anacronia inerente às silepses favorece o reconhecimento da repetição.

A predominância da abordagem temática no terceiro capítulo é determinante tanto para facilitar a identificação das perturbações que enfraquecem a temporalidade linear devido principalmente à descontinuidade temporal e à permutabilidade narrativa de alguns eventos, uma vez que a determinação temporal de alguns é imprecisa mesmo em termos relativos ou é tematizada de tal modo que a sua ordenação se torna irrelevante, quanto para diminuir a dispersão das várias ocorrências de uma mesma repetição. Observemos que a promoção da identificação das recorrências diferencia as 
relações que a silepse temática e a temporalidade de onda estabelecem com a repetição do recalcado, pois esta é sistematicamente distorcida pela mera sucessão do regime temporal da casualidade dentro da autobiografia.

No que se refere especificamente ao conteúdo, o tema ao qual o terceiro capítulo é dedicado - o vício do fumo - também reforça o efeito de promover a identificação das recorrências, pois se trata de um dos principais elementos do comportamento repetitivo do protagonista no sentido de que não só nunca deixou de ser repetido, mas também não sofreu mudanças no modo como opera como repetição edipiana, já que Zeno sempre sente necessidade de fumar ou faz mais uma tentativa de parar com o vício. Além disso, como essas observações também valem para o narrador, a abordagem de tal tema bloqueia o surgimento de repetições divergentes com o protagonista, um dos fatores que dificultam o reconhecimento dos padrões repetitivos da história de Zeno.

Assim, a adoção da silepse temática como forma principal do terceiro capítulo e o fato de quase não haver variações na repetição de Zeno da qual trata o relato operam conjuntamente para criar a melhor oportunidade da autobiografia para a identificação inicial da compulsão repetitiva de Zeno, o qual até mesmo reconhece explicitamente, como narrador, a presença da repetição na sua vida, ainda que isso seja feito de modo muito vago e limitado.

Por fim, consideramos que há uma função preparatória no fato de a autobiografia iniciar com o capítulo de maior facilidade para reconhecer o enfraquecimento da temporalidade linear da narrativa e as repetições de Zeno. Propomos que o capítulo de abertura tenta preparar o leitor para que preste a atenção necessária para identificar as repetições nos capítulos seguintes, nos quais a tarefa de reconhecê-las é bastante dificultada, conforme comentaremos a seguir, inclusive porque a temporalidade linear perde a posição subordinada na abordagem adotada pelo narrador. Notemos que a mesma função de preparação responderia pelo fato de os únicos reconhecimentos diretos da repetição pelo narrador também se encontrarem nessa abertura.

Uma vez que examinamos a situação peculiar do terceiro capítulo dentro da autobiografia, investiguemos as mudanças que estabelecem o padrão de articulações entre as temporalidades que estudamos no início da presente seção para os demais capítulos autobiográficos. Começaremos analisando como é estabelecida a nova abordagem que o narrador adota e quais são as consequências de tal transformação e, 
por fim, trataremos da proliferação de variações divergentes das repetições abordadas.

O narrador adota uma nova abordagem logo no começo do quarto capítulo, no qual encontramos a próxima grande opção narrativa de Zeno após a opção implícita por uma das duas recomendações do doutor S., um processo que inicia no preâmbulo e só termina nos primeiros parágrafos do terceiro capítulo. Comentamos que a abordagem desse capítulo foi dada pelo psicanalista, mas o próximo começa com a seguinte declaração: "Il dottore è partito ed io davvero non so se la biografia di mio padre occorra" ${ }^{80}$ (2004, p. 653). Logo, a próxima etapa da autobiografia não se origina de uma recomendação médica, pois é uma escolha do narrador, e isso também ocorre nos demais capítulos. Em termos do tempo da narrativa, a silepse temática se torna subordinada à cronologia, como explicitaremos adiante. Em termos de assunto, a primeira escolha recai sobre o pai e não é efetivamente justificada; de fato, podemos nos perguntar por que Zeno não resolve contar algo sobre a biografia da mãe ou do irmão ou sobre os tempos da escola, etc.

Como resposta à questão sobre a escolha do assunto do quarto capítulo, podemos propor que o narrador obedece em boa medida à lógica de formações de compromisso entre a consciência e o recalcado, pelo qual o sujeito só permite que este se manifeste para aquela por meio de procedimentos de distorção, como o deslocamento, segundo o qual os componentes do recalcado tendem a ser tratados na proporção inversa à sua importância: os menos importantes se tornam os principais elementos do que é representado, e os mais relevantes podem simplesmente não serem manifestados. De fato, a escolha em análise permite que, por um lado, o narrador, ao relatar a vida com o pai após a morte da mãe, aborde uma época na qual ainda está presente um elemento ligado às origens da doença, o próprio pai, ou seja, o primeiro rival edipiano, e, por outro lado, dado que a narrativa de Zeno se torna predominantemente cronológica, só aborde a época final de tal presença e evite, portanto, os momentos mais importantes da convivência com o pai e a mãe, principalmente a infância.

Quanto ao quinto, sexto e sétimo capítulos, não começam mais mencionando o tratamento, como acontece com os dois primeiros da autobiografia, e o assunto deles é obtido por meros recortes consecutivos da continuação da história iniciada no quarto capítulo, o que é um dos aspectos da subordinação da silepse temática à cronologia, da

\footnotetext{
${ }^{80}$ Com o médico ausente, não sei na verdade se a biografia de meu pai é necessária (2006, p. 39).
} 
qual trataremos após explicitarmos um pouco mais a relação das mudanças na narrativa produzida por Zeno com o seu contexto terapêutico.

Assim, no que se refere à escolha do assunto de cada capítulo a partir do quarto, há uma dissociação entre os principais elementos específicos do tempo da narração; mais precisamente, não há mais influência direta do tratamento com o doutor S. sobre a escrita autobiográfica. De modo equivalente, a autobiografia perde as frequentes referências explícitas à terapia que tinha no terceiro capítulo. De fato, as centenas de páginas dos capítulos seguintes da autobiografia trazem apenas algumas referências explícitas à terapia, todas de pouca importância. Logo, a narrativa perde, em grande medida, o contexto terapêutico e parece se restringir à finalidade propriamente autobiográfica. Na verdade, a terapia continua a influenciar Zeno, como é o caso das repetições do narrador que analisamos como estando ligadas à leitura do tratado psicanalítico, mas o seu efeito se tornou velado. Por meio das noções aprendidas por essa leitura e sem identificá-las como tais, o narrador distorce repetições edipianas, seja intervindo explicitamente, seja sobrepondo silenciosamente um tempo mítico.

Encontramos a mesma dissociação entre terapia e autobiografia quando consideramos os tempos da narração e da narrativa. Afinal, após rejeitar a recomendação para valorizar o presente do narrador para recuperar o passado, Zeno também se afasta da predominância temática inerente à orientação do doutor S. para iniciar pela análise da propensão ao fumo ao privilegiar a abordagem cronológica a partir do quarto capítulo: tanto porque Zeno escolhe o pai como assunto inicial, prossegue o relato basicamente acompanhando a própria vida da morte do pai à partida de Ada e o recorta tematicamente em capítulos que correspondem a etapas da vida burguesa quanto porque os trechos efetivamente temáticos são curtos e nunca ameaçam a predominância cronológica da narrativa.

Logo, o narrador inverte a relação predominante no terceiro capítulo, de modo que a silepse temática se torna secundária frente à cronologia. Ora, tal inversão reduz drasticamente nos capítulos seguintes os efeitos que essa predominância da silepse contribui para produzir, a saber, as perturbações mais nítidas da cronologia e a promoção da identificação das repetições. Como a tendência a evitar o reconhecimento do recalcado e das suas recorrências é inerente à compulsão de repeti-lo, consideramos que a inversão em análise é resultado de mais uma das repetições edipianas do narrador.

Por fim, tratemos da proliferação de variações divergentes das repetições do recalcado a partir do quarto capítulo. Ao examinarmos o tema do terceiro capítulo, 
ressaltamos que se trata de uma repetição que não sofre mudanças no modo pelo qual opera. As recorrências edipianas na continuação da autobiografia geralmente não funcionam assim, pois estabelecem conflitos entre si e a participação das recorrências nos diversos conflitos se modifica conforme a evolução dos mesmos. Isso vale não só para o protagonista no decorrer do tempo da história, mas também para os arranjos repetitivos do protagonista e do narrador com respeito ao mesmo trecho da narrativa, uma vez que a mesma repetição pode estar operando em cada um dos dois arranjos de modos que se opõem entre si.

Como já comentamos em outros contextos de investigação do presente trabalho, ambos os processos de produção de variações divergentes de repetições dificultam o reconhecimento da compulsão repetitiva, o que é um resultado convergente com o da subordinação da abordagem temática à cronológica. No caso das variações que surgem na sucessão da própria história, já analisamos o dinamismo diegético que torna difusa as recorrências do protagonista ao examinar detalhadamente as oito etapas da relação com Carla na quarta seção do capítulo anterior. No caso das variações num mesmo segmento narrativo, envolvendo o protagonista e o narrador, foi na presente seção que tratamos dos modos pelos quais as repetições divergentes contribuem para causar a temporalidade de onda, a qual não pode afirmar a sucessão casual sem negar em grande medida as recorrências que permeiam o texto.

Em suma, consideramos que o primeiro capítulo da autobiografia, devido tanto ao vínculo da escrita autobiográfica ao tratamento com o doutor S. por meio da abordagem temática quanto ao tema ser uma repetição de baixo grau de variação, apresenta perturbações mais nítidas da temporalidade linear e promove a identificação das repetições a ponto de concorrer em alguns trechos com o estabelecimento de uma temporalidade de onda, de modo que esse capítulo serve de preparação para os demais da autobiografia, nos quais a subordinação da organização temática à cronológica e a diversidade de recorrências com variações relevantes dificultam bastante 0 reconhecimento das repetições, de modo a fazer com que prevaleça o embate direto entre as temporalidades linear e de onda, conforme analisamos minuciosamente ao longo do presente capítulo. 


\section{Capítulo 4 \\ A REPETIÇÃO DO RECALCADO E A ELABORAÇÃO DAS ARTICULAÇÕES TEMPORAIS NO ÚLTIMO CAPÍTULO E NO ÂMBITO GLOBAL DO ROMANCE LA COSCIENZA DI ZENO}

No presente capítulo nos dedicaremos ao último capítulo e ao âmbito global do romance, dos quais investigaremos as transformações da repetição do recalcado e das articulações temporais. Elaboraremos a relação entre a noção psicanalítica da compulsão à repetição do recalcado e a criação literária neste capítulo com base na construção do enredo, o qual desenvolve o contexto clínico da história por meio das sessões com o doutor S., no tempo literário, por meio das relações entre os tempos da história, da narrativa e da narração, e na escrita de Zeno, que finalmente deixa de ser uma autobiografia.

Considerando que o último capítulo foi ficcionalmente escrito por Zeno em quatro datas, chamaremos o trecho escrito em cada uma dessas datas de uma seção. A fim de cumprirmos a tarefa que estabelecemos para este capítulo do presente trabalho, estudaremos a primeira e a segunda seções - as do abandono da terapia e do passeio no campo - com base na repetição do recalcado de Zeno dentro do contexto clínico da terapia com o doutor S.; investigaremos as mudanças nessa repetição que são apresentadas no relato sobre o passeio no campo e as relações de tais alterações com o relato sobre o abandono da terapia e com o capítulo como um todo; também investigaremos as mudanças no mesmo processo repetitivo que são apresentadas na quarta seção; e concluíremos com o estudo tanto das transformações das articulações temporais que são delineadas no âmbito global do romance quanto da temporalidade resultante da combinação dessas transformações.

4.1. A articulação da repetição do recalcado com o contexto clínico: a primeira seção do diário e o propósito subjacente à escrita das seções iniciais

Dedicamos esta seção a expor o quanto as duas seções iniciais do diário, principalmente a primeira, operam com a repetição do recalcado do modo que 
apresentamos nos dois capítulos anteriores do presente trabalho, apesar das diferenças causadas pela novidade do contexto clínico dado pelas sessões de psicanálise com o doutor S. Comecemos pela análise da primeira seção do diário, na qual novamente abordaremos isoladamente as repetições do protagonista e do narrador e, no que se refere ao primeiro caso, o dividiremos em duas partes que estão separadas pelo anúncio do diagnóstico de Zeno pelo psicanalista.

Antes de o doutor S. anunciar o diagnóstico de complexo de Édipo, Zeno é um paciente colaborativo; de fato, ele relata ao psicanalista os quatro sonhos, os quais são um grande sucesso clínico, pois, conforme já examinamos nos dois capítulos anteriores, tanto a ordem na qual ocorrem está em perfeita conformidade com a temporalidade invertida das recordações traumáticas, tal como proposto por Freud, quanto permitem que elementos cruciais do inconsciente do protagonista ganhem expressão, tais como as suas relações com o irmão e a mãe, o canibalismo e o fetichismo. As referências a tais elementos nos capítulos anteriores do romance são tão pontuais e esparsas que essa expressão obtida durante o tratamento é decisiva, dando suporte à sua compreensão adequada. Podemos fazer a mesma afirmação no que se refere à compreensão das associações que Zeno estabelece para dois elementos já usados nos seus relatos: a dificuldade para caminhar e a letra inicial dos nomes.

É importante que registremos as reações imediatas de Zeno aos sonhos relatados ao doutor S., pois ele as renegará, ainda na condição de protagonista, conforme analisaremos adiante. Ele destaca o grau de realidade das manifestações oníricas, ao qual dedica um parágrafo (2004, p. 1050-1051). A esse trecho podemos acrescentar manifestações mais pontuais sobre a mãe se mover como uma pessoa viva numa das aparições (2004, p. 1054) e sobre a semelhança com o espaço nesse acesso a supostos momentos da própria infância (2004, p. 1054). Explicitemos que tais considerações correspondem a uma característica especialmente distintiva dos sonhos segundo a teoria de Freud, que a chamou de representabilidade em imagens sensoriais (1987a, p. 489). Além disso, Zeno declara a crença que teve em tais imagens oníricas na continuação do primeiro e do terceiro trechos que citamos. Por fim, o protagonista dá demonstrações de fortes reações emocionais aos eventos oníricos, como as lágrimas (2004, p. 1050) e as emoções cuja intensidade é suficiente para interromper os sonhos da colher (2004, p. 1053) e da tinta derrubada (2004, p. 1054).

Em acréscimo ao âmbito do que foi efetivamente sonhado, o próprio contexto clínico promove manifestações menos distorcidas do recalcado, o que é propício às 
repetições do protagonista, como é registrado de duas maneiras no diário. Na primeira, ele busca obter, conforme as suas palavras, recordações que sejam as rosas de maio em pleno inverno (2004, p. 1050), o que é compatível com a tendência contrária ao reconhecimento do recalcado e com a compulsão à repetição. A segunda maneira é formada por aplicações do caso geral dado pela primeira. São repetições do desejo pela mãe na forma de lamentos devido às interrupções dos sonhos da colher e da tinta derrubada: Zeno lamenta não haver visto a mãe que talvez viesse ajudar a empregada a puni-lo (2004, p. 1053-1054) nem o ato de proteção materna diante da ameaça de punição do pai (2004, p. 1054).

Não encontramos mais nenhuma atitude de colaboração do protagonista em relação à terapia psicanalítica depois que o doutor $\mathrm{S}$. anuncia o diagnóstico de complexo de Édipo. Na verdade, a única característica que destacamos da fase inicial do protagonista que se conserva após o diagnóstico é a busca em obter as tais rosas de maio, mas sem o sucesso obtido na etapa anterior (2004, p. 1057). Dividiremos a fase posterior ao diagnóstico em duas partes: a continuidade das sessões de psicanálise e a interrupção da terapia. Trataremos da primeira parte abordando a causa clínica de tantas alterações e investigando as principais mudanças provocadas nas repetições do recalcado do protagonista.

No contexto da clínica psicanalítica, inerente à primeira seção do diário, há um fenômeno crucial, que é denominado de resistência: "quando assumimos a tarefa de recuperar um paciente para a saúde, aliviá-lo dos sintomas de sua doença, ele nos enfrenta com uma resistência intensa e persistente, que se prolonga por toda a duração do tratamento" (FREUD, 1976a, p. 337). Esse fenômeno é tão importante que define a segunda das duas fases nas quais Freud divide a terapia: "Primeiro, a busca pela repressão e, depois, a remoção da resistência que mantem a repressão" (1976a, p. 509). O tratamento também é dividido em duas partes pelo doutor S., que, após chegar ao diagnóstico, muda a condução das sessões; como observa Zeno, o psicanalista inicia a reeducação do paciente (2004, p. 1056). Ao compararmos as duas bipartições, verificamos que, ainda que possamos avaliar como demasiado restrita a concepção que o doutor S. tem dos efeitos do complexo de Édipo em Zeno, a parte inicial do método clínico coincide em ambos os casos, o que podemos declarar sobre a etapa final somente se a mencionada reeducação consistir em remover a resistência. Para nos auxiliar na avaliação de tal condição, recorramos à concepção de Freud sobre essa remoção: 
mostrando-a ao paciente. Na realidade, também a resistência deriva de uma repressão - da mesma repressão que nos esforçamos por solucionar, ou de uma repressão que se realizou anteriormente. Foi provocada pela anticatexia, que surgiu a fim de reprimir o impulso censurável. Assim, fazemos o mesmo que tentamos fazer inicialmente: interpretar, descobrir, comunicar; mas, então, estamos fazendo-o no lugar certo. A anticatexia ou a resistência não fazem parte do inconsciente, e sim do ego, que é nosso colaborador, sendo-o, ainda que não consciente. (1976a, p. 509)

Ora, não encontramos indício de que o doutor S. trabalhe da maneira descrita na citação; em vez disso, a sua proposta de reeducação do paciente parece ganhar uma descrição adequada no seguinte comentário de Freud:

O que, pois, devemos fazer a fim de substituir o que é inconsciente, em
nossos pacientes, por aquilo que é consciente? Houve uma época em que
pensávamos ser isto algo muito simples: tudo o que tínhamos de fazer era
descobrir esse material inconsciente e comunicá-lo ao paciente. Já sabemos,
porém, que este é um erro primário. O nosso conhecimento acerca do
material inconsciente não é equivalente ao conhecimento dele; se lhe
comunicamos nosso conhecimento, ele não o receberá em lugar de seu
material inconsciente, mas ao lado do mesmo; e isso causará bem pouca
mudança no paciente. (1976a, p. 509)

De fato, o doutor $S$. se restringe justamente a comunicar o material inconsciente que descobriu a Zeno, confundindo o próprio conhecimento com o do paciente. Consequentemente, não considera devidamente as reações do paciente ao tentar curá-lo, deixando que a resistência aja livremente. O melhor exemplo desse descompasso na condução do tratamento é a tentativa de curar o protagonista do que este considera uma doença, o seu hábito de fumar (2004, p. 1059): por um lado, o doutor S. simplesmente argumenta que a relação do paciente com o fumo era baseada na competição com o pai e, agora que Zeno sabia disso, não havia mais razão para ele achar que esse hábito lhe fizesse mal; por outro lado, o protagonista sai da sessão fumando um cigarro depois do outro até que a sua broquite crônica se manifeste, de modo que conclui que o tabagismo lhe faz mal e, portanto, negue as declarações do psicanalista sobre a sua doença. A hiperbólica frequência de cigarros, que serve a Zeno para se contrapor ao tratamento por meio dos seus efeitos, é uma manifestação da resistência e, portanto, deveria ser diretamente combatida pelo doutor S. argumentando, por exemplo, que essa frequência deve ter um limite, o qual depende inclusive das condições físicas do fumante. Para agravar a situação, Zeno simplesmente diz ao psicanalista que fumou muito e não se importa mais com isso, de modo que lhe oculta a resistência, um fenômeno também comentado por Freud (1976a, p. 341). Após o diagnóstico, o ocultamento é recorrente nas atitudes do protagonista, que esconde os 
pensamentos por meio de um respeito exagerado ao doutor S. (2004, p. 1049) e guarda para si as objeções a ele quanto ao efeito da nicotina sobre o experimento com as cores (2004, p. 1058) e à antipatia contra Guido demonstrada pela ausência no seu funeral (2004, p. 1060).

Em suma, consideramos que a causa da mudança do protagonista após o diagnóstico é o fenômeno clínico da resistência, cuja atuação sem controle é uma grave falha profissional do doutor S. Para completar a nossa análise da primeira parte da fase da história posterior ao diagnóstico, verifiquemos quais são as principais transformações causadas pela resistência no tocante à compulsão à repetição do protagonista: elas acontecem na sua relação com os sonhos e com o psicanalista.

Os sonhos obtidos durante a terapia merecem especialmente a nossa atenção, pois o diagnóstico os transforma de supostas recordações da infância em explícitas repetições da rivalidade contra o pai e o irmão e do desejo pela mãe. Para evitar o reconhecimento dos sonhos como repetições do recalcado, o protagonista efetua uma desqualificação retrospectiva deles e das reações inicialmente favoráveis que teve a eles.

Assim, após os relatos dos sonhos da ida à escola e com a mãe, somos informados de julgamentos futuros do protagonista que desqualificariam a confiança que teve nessas produções oníricas: no primeiro caso, o suposto deslocamento da inveja (2004, p. 1052), e, no segundo caso, a hipótese de que o sonho seria apenas uma variação mais infantil daquele que teve com Carla (2004, p. 1055-1056). De modo equivalente, quando o doutor S. alega que as observações de Zeno sobre as cores são provocadas pela nicotina, o protagonista não resiste a pensar na hipótese de que os seus sonhos também poderiam ser efeitos dessa substância (2004, p. 1058).

Também contribui para a desqualificação em análise o sonho simulado pelo protagonista (2004, p. 1056-1057), pois não somos informados sobre nenhum indício de que o doutor S. reconheça a farsa e, portanto, somos assaltados pela dúvida sobre o quão competente ele é para reconhecer falsidades menos grosseiras nos sonhos que não foram simulados.

Quanto à relação do protagonista com o doutor S., ela é transformada por meio de uma forma específica de resistência, a transferência negativa, segundo a qual há repetição de sentimentos hostis, provenientes de uma relação anterior com outra pessoa (FREUD, 1976a, p. 342). No caso de Zeno, o doutor S. se torna mais um dos substitutos paternos, e a rivalidade edipiana contra ele é realizada colocando em dúvida a sua capacidade como terapeuta de variadas maneiras. No que se refere ao protagonista, 
encontramos essa transferência negativa na reação supostamente presunçosa do doutor S. quando Zeno lhe mente que não se importa mais com o tabagismo (2004, p. 1059), pelo ridículo que supostamente sentiria caso contasse que havia se entregado ao que qualifica de charlatanice (2004, p. 1061-1062) e, já na segunda parte da fase posterior ao diagnóstico, na curiosidade de saber como o psicanalista trataria do diabetes, uma hipótese diagnóstica que Zeno recebe do doutor Paoli (2004, p. 1063).

Sem as devidas providências para remover a resistência, a terapia não avança, ficando estagnada na repetição da rivalidade edipiana de Zeno com o novo substituto paterno. A situação só muda, dando início à segunda parte da fase posterior ao diagnóstico, após uma inesperada descoberta do doutor S.:

\begin{abstract}
Pare che il dottore a proposito di Guido abbia fatte anche delle indagini. Egli asserisce che, scelto da Ada, egli non poteva essere quale io lo descrissi. Scoperse che un grandioso deposito di legnami, vicinissimo alla casa dove noi pratichiamo la psico-analisi, era appartenuto alla ditta Guido Speier \& C. Perché non ne avevo io parlato? [...]

Io proposi al dottore di prendere delle informazioni su Guido da mia moglie, da Carmen oppure da Luciano ch'è un grande commerciante noto a tutti. ${ }^{81}$ (2004, p. 1060-1061)
\end{abstract}

Em contraste com a falta de qualquer esforço voltado a enfrentar a resistência de Zeno por parte do doutor S., essa passagem é a única em todo o tratamento na qual ele demonstra desconfiar da capacidade do paciente em colaborar com o processo de cura. De fato, ele não questiona Zeno imediatamente sobre possíveis problemas na descrição que este fizera de Guido. Por meio de indagações (pelo menos essa é a hipótese do narrador), descobre algo que o seu paciente não havia lhe contado. De qualquer modo, o que nos importa é que Zeno não é procurado para dirimir a dúvida a respeito de Guido. Assim, o doutor S. comete dois erros simétricos ao tratar o paciente: quando conduz o processo de cura sem combater a resistência, é de uma confiança ingênua na colaboração deste com a terapia; quando finalmente desconfia de tal colaboração, reage de modo extremo, recusando qualquer participação do doente.

Descoberta a omissão de Zeno, o psicanalista confronta-o diretamente, questionando-lhe o motivo desse comportamento. O protagonista reage evasivamente, propondo que o doutor S. descubra mais sobre Guido com outras pessoas, ou seja, que

\footnotetext{
${ }^{81}$ Parece que ele [o doutor S.] andou fazendo algumas indagações a propósito de Guido. Admitiu que, tornando-se o eleito de Ada, não podia ser como eu o descrevera. Descobriu que um imenso depósito de madeiras, vizinho à casa onde praticávamos a psicanálise, pertencia à firma Guido Speier \& Cia. Por que eu não lhe falara sobre isto? [...]

Propus ao doutor que obtivesse informações sobre Guido através de minha mulher, de Carmen ou mesmo de Luciano, que era um grande comerciante conhecido de todos (2006, p. 400).
} 
continue a fazer descobertas sem a participação do paciente. Obviamente, isso não dá nenhum indício para identificar o motivo da omissão mencionada.

Como o questionamento mencionado é o último relato sobre as sessões de psicanálise, fica a sugestão de que é o confronto direto para o qual o paciente não tem uma resposta para enganar o psicanalista com uma colaboração simulada que desencadeia a decisão de interromper o tratamento, ou seja, o que ponderamos ser a segunda parte da fase posterior ao diagnóstico. De fato, a quebra de confiança torna o psicanalista um rival fora da repetição da relação com o pai, que é sempre velada sob um relacionamento amistoso, conforme examinamos no segundo capítulo.

Com base na nossa análise da última citação, consideramos que a incapacidade de manter a relação de rivalidade com o doutor S. devido à desconfiança causada pela omissão que este descobriu no relato de Zeno sobre Guido e que foi deixada sem justificativa é a causa das principais mudanças do protagonista na segunda parte da fase posterior ao diagnóstico, as quais ocorrem na relação de Zeno com a terapia, o que inclui os sonhos, e com a autobiografia.

No tocante à terapia, o protagonista começa a tratá-la como se fosse uma doença, o que podemos observar no mal estar e no abatimento que atribui respectivamente aos sonhos e à liberdade para fumar (2004, p. 1061), uma vez que ambos foram propiciados pelo tratamento com o doutor S. No que tange aos sonhos, destaquemos que a alegação de que produziriam mal estar é mais uma desqualificação do fenômeno onírico, em conformidade com o processo que analisamos ao abordarmos a parte inicial da fase posterior ao diagnóstico. Também podemos observar a patologização da terapia por parte do protagonista no fato de ele se dedicar nessa época a duas repetições oscilatórias de cuidados com a saúde, a consulta com o doutor Paoli (2004, p. 1061-1063) e o tratamento contra a neurastenia concebido pelo doutor Beard (2004, p. 1063-1064). A constituição de tais apelos à medicina como repetições de cuidados com a saúde, as quais apresentamos no segundo capítulo, é especialmente ressaltada pelo paralelo textual entre os relatos das consultas com o médico que emprega eletricidade e com o doutor Paoli: de fato, o primeiro relato apresenta o trecho "correvo a quelle sedute nella speranza di convincere il dottore a proibirmi il fumo. Chissà come sarebbero andate le cose se allora fossi stato fortificato nei miei propositi da una proibizione simile" 82 (2004, p. 636), cuja construção é muito semelhante à do

\footnotetext{
82 [...] corria ao consultório na esperança de convencer o médico a me proibir de fumar. Quem sabe as coisas tomariam outro rumo se meus propósitos fossem fortificados por uma tal proibição (2006, p. 22)?
} 
trecho do segundo no qual lemos "Ero salito da lui [Paoli] col proposito di domandargli se credeva dovessi continuare la psico-analisi. [...] se il Paoli m'avesse proibita la psicoanalisi, la mia posizione sarebbe stata semplificata di molto" (2004, p. 1061-1062). ${ }^{83}$

Quanto à autobiografia, ela é somente a fonte da história de Zeno durante as sessões de psicanálise; de fato, ela só é considerada sob aspectos que extrapolam o âmbito do que é relatado após a interrupção da terapia. Essa situação acontece com o protagonista apenas uma única vez, quando encontra casualmente o doutor S. e cogita lhe pedir o manuscrito de volta, mas resolve adiar o pedido para uma oportunidade mais favorável. Para analisarmos devidamente esse momento da história, precisamos considerar também as atitudes correspondentes do narrador; por ora, nos contentaremos em sugerir um possível paralelo entre a desqualificação dos sonhos após o diagnóstico dado pelo doutor $\mathrm{S}$. com base no último deles e essa tentativa de lhe subtrair o manuscrito após a sua descoberta de uma omissão de Zeno ao duvidar da descrição de Guido nesse relato.

Para finalizarmos a análise sobre a segunda parte da fase da história posterior ao diagnóstico, ressaltemos que a resistência continua operante no protagonista apesar da interrupção. Observemos inicialmente que, ao tratarmos da transferência negativa, já apresentamos um caso no qual ela continua a operar na parte em análise, o qual é baseado na suspeita de diabetes que surge durante a consulta ao doutor Paoli. O mesmo episódio proporciona dois exemplos bastante elaborados de outras formas de resistência. O primeiro é um caso de uma das vertentes da resistência nomeada como intelectual; mais precisamente, daquela que consiste na argumentação que explora as dificuldades e improbabilidades que um pensamento sem a instrução adequada encontra nas concepções psicanalíticas (FREUD, 1976a, p. 337). De fato, com base no exame a que se submete para verificar a suspeita de diabetes, o protagonista faz uma comparação desfavorável da psicanálise, na qual ele enganou o psicanalista com o sonho simulado, em relação a uma ciência amplamente reconhecida, a química, na qual a substância analisada oferece pouca resistência ao ser submetida ao reagente (2004, p. 1062), mas a dificuldade tematizada por Zeno é exatamente a resistência sobre a qual comentamos na presente seção, quando expusemos que Freud justamente orientava a dedicar a segunda parte da terapia à remoção desse obstáculo.

\footnotetext{
${ }^{83}$ Fui ao seu consultório [Paoli] com o propósito de perguntar se eu devia continuar as sessões de psicanálise. [...] se o dr. Paoli me tivesse proibido a psicanálise, minha posição ficaria bastante simplificada (2006, p. 401).
} 
O segundo exemplo de resistência do protagonista na consulta ao doutor Paoli é um caso de outra forma desse fenômeno clínico que Freud registrou, a qual recorre a um acontecimento pertubador externo à análise, sendo que um dos exemplos que ele forneceu para tal evento é uma doença orgânica eventual (1976a, p. 343). O exemplo em questão é a intensa reação de Zeno à suspeita de diabetes, apesar de o próprio doutor Paoli dizer que não acredita nessa hipótese:

\begin{abstract}
Io, intanto, me ne andai glorioso, carico di diabete. [...]
Devo confessare che il diabete fu per me una grande dolcezza. [...]

Io amavo la mia malattia. Ricordai con simpatia il povero Copler che preferiva la malattia reale all'immaginaria. Ero oramai d'accordo con lui. La malattia reale era tanto semplice: bastava lasciarla fare. Infatti, quando lessi in un libro di medicina la descrizione della mia dolce malattia, vi scopersi come un programma di vita (non di morte!) nei varii suoi stadii. Addio propositi: finalmente ne ero libero. Tutto avrebbe seguito la sua via senz'alcun mio intervento. ${ }^{84}$ (2004, p. 1063)
\end{abstract}

A mera suspeita de estar com diabetes já é suficiente para Zeno ser tomado pela convicção de estar realmente doente e de que deverá dedicar-se completamente à doença, fornecendo justamente o motivo procurado para manter-se afastado das sessões. Assim, não é por acaso que, quando Paoli lhe diz que ele não é diabético, Zeno receba a notícia como se alguém cujo apoio lhe fosse de grande importância houvesse partido (2004, p. 1063).

Uma vez que analisamos a articulação da repetição do recalcado com o contexto clínico no caso do protagonista, completaremos a investigação da primeira seção do diário com a análise correspondente para o narrador. Comecemos abordando a transição do protagonista para o narrador, a qual nos servirá de base para investigar a construção textual da primeira seção por Zeno.

Analisaremos a transição de Zeno de protagonista para narrador do diário recorrendo a cinco elementos de tal processo. O primeiro deles é o abandono da terapia, o qual é concomitante ao início do tempo da narração do último capítulo. Com efeito, o protagonista tanto não consegue abandonar a terapia com as repetições de cuidados com a saúde, por meio das quais apenas adia o retorno às sessões de psicanálise, como o próprio Zeno declara (2004, p. 1064), quanto ainda posterga o retorno a elas no dia

\footnotetext{
${ }^{84} \mathrm{Eu}$, no entanto, saí do consultório glorioso, carregado de diabete. [...]

Devo confessar que o diabete foi para mim de uma grande doçura. [...]

Eu amava a minha doença. Recordei com simpatia o pobre Copler que preferia a doença real à imaginária. Agora, concordava com ele. A doença real era tão simples: bastava deixá-la agir. De fato, quando li num livro de medicina a descrição de minha doce enfermidade, descobri um programa de vida (não de morte!) em seus vários estágios. Adeus propósitos: era finalmente livre. Tudo seguiria o seu destino sem a minha intervenção (2006, p. 402).
} 
anterior ao qual inicia a escrita do diário mandando dizer ao doutor $\mathrm{S}$. que estava impossibilitado de ir à consulta (2004, p. 1048), mas o narrador inicia o diário com o anúncio do mencionado abandono: "L'ho finita con la psico-analisi. Dopo di averla praticata assiduamente per sei mesi interi sto peggio di prima"85 (2004, p. 1048).

O segundo elemento da transição de Zeno de protagonista para narrador também está presente na citação que fizemos do início do diário; mais precisamente, ele está presente por meio da avaliação do narrador de que está pior do que antes da terapia. Esse julgamento remete ao último momento da história da primeira seção do diário, o encontro do protagonista com o doutor S., cujo relato encerra com a seguinte declaração do psicanalista: “- Se lei esamina il suo animo, lo troverà mutato. Vedrà che ritornerà subito a me solo che s'accorga come io seppi in un tempo relativamente breve avvicinarla alla salute" 86 (2004, p. 1064).

Associando os dois elementos que apresentamos, propomos a seguinte articulação entre o protagonista e o narrador: este conclui que a terapia o piorou como resposta à investida final do doutor S. sobre o protagonista - segundo a qual Zeno voltaria à terapia porque eventualmente reconheceria o aprimoramento de saúde que a psicanálise lhe proporcionou -, pois essa conclusão garante que a investida para que retome as sessões não terá êxito, e o protagonista se torna narrador justamente a fim de escrever a história da terapia de forma a favorecer a negação do aprimoramento alegado pelo doutor S. Consideramos que o o restante da nossa análise da primeira seção do diário no que concerne ao narrador evidencia a capacidade da nossa proposta para extrair uma rede de relações que abarque uma ampla gama de elementos do texto. Por ora, assinalemos dois trechos do início do diário que consideramos como indícios da nossa proposta. No primeiro trecho, a capacidade de distorção da escrita é tematizada na recomendação do psicanalista para que Zeno parasse de escrever a autobiografia a fim de não reforçar as tendências que impedem a sinceridade e a entrega (2004, p. 1048). No segundo trecho, o narrador efetivamente declara que a psicanálise piorou a sua saúde e que escreve para combater tais efeitos do tratamento: "Ma ora mi trovo squilibrato e malato più che mai e, scrivendo, credo che mi netterò più facilmente del male che la

\footnotetext{
85 Acabei com a psicanálise. Depois de havê-la praticado assiduamente durante três [sic] meses inteiros, sinto-me pior do que a princípio (2006, p. 389).

86 - Se o senhor examinar seu espírito há de encontrá-lo mudado. Verá que retornará aos meus cuidados, tão logo se aperceba de como eu consegui em tempo relativamente curto aproximá-lo da saúde perfeita (2006, p. 403).
} 
cura m'ha fatto" ${ }^{87}$ (2004, p. 1048).

O terceiro elemento da transição de Zeno de protagonista para narrador é a relação com os cuidados da saúde, o que envolve os dois elementos anteriores. A conclusão do narrador de que a sua saúde piorou fornece justamente o pretexto para abandonar a terapia que o protagonista buscava nos cuidados terapêuticos. Logo, a conjunção do segundo e do terceiro elementos da transição justificam o primeiro, ou seja, que o referido abandono seja concomitante à constituição de Zeno como narrador da terapia. Aproveitemos para destacar que a reciprocidade que se estabelece entre as repetições oscilatórias dos cuidados com a saúde e o abandono do tratamento com o doutor S. devido a essa desistência inclui definitivamente a própria terapia psicanalítica, que também deu origem à autobiografia de Zeno, na série das mesmas repetições oscilatórias.

O quarto elemento da transição de protagonista para narrador é a hostilidade velada de Zeno, da qual identificamos mais uma ocorrência no fato de a dupla refutação da investida do doutor S. se realizar por uma escrita privada como o diário, dado que Zeno não conseguiria declarar ao psicanalista que a sua saúde não melhorou ou que desistiu do tratamento. Isso é até mesmo aludido no que se refere à desistência não só por Zeno, como narrador, deixar de avisar o doutor S. sobre a sua decisão, mas também por inventar um pretexto, amparado na transferência negativa, para evitar o reencontro com o psicanalista: "Non ho ancora congedato il dottore, ma la mia risoluzione è irrevocabile. [...] Se fossi ben sicuro di saper ridere di lui senz'adirarmi, sarei anche capace di rivederlo. Ma ho paura che finirei col mettergli le mani addosso"88 (2004, p. 1048). Na verdade, a dispensa só ocorrerá vários meses depois, mas verificaremos que então a situação estará muito mudada.

O quinto e último elemento da transição de Zeno de protagonista para narrador é a escrita do diário como reação ao tédio da temporalidade da nota única que é instaurada pelo abandono da terapia, dado que esta concentra as principais repetições do recalcado para Zeno nessa época. De fato, o diário justamente retoma a rivalidade contra o doutor S. ao ser dedicado a desautorizar a sua competência profissional. O próprio narrador ressalta que escreve por causa do tédio já no início da primeira seção

\footnotetext{
${ }^{87}$ Hoje, contudo, acho-me mais desequilibrado e enfermo do que nunca e, escrevendo, creio que me livrarei mais facilmente do mal que a cura me provocou (2006, p. 389).

${ }^{88}$ Ainda não despachei o doutor, mas minha resolução é irrevogável. [...] Se estivesse bastante seguro de poder rir dele sem me irritar, seria até capaz de voltar a vê-lo. Tenho medo, porém, de chegar às vias de fato (2006, p. 389).
} 
do diário, inclusive mencionando a substituição da psicanálise pela escrita (2004, p. 1048), e também na terceira seção (2004, p. 1070).

Em suma, a partir dos cinco elementos apresentados, propomos que a instauração de Zeno como narrador do diário é uma manifestação da resistência contra a investida do doutor S. para retomar a terapia do protagonista com base num suposto aprimoramento da saúde deste na medida em que o diário é dedicado a estabelecer que a saúde de Zeno piorou com a psicanálise e é produzida por meio da articulação com algumas repetições do recalcado: com a hostilidade velada referente ao suposto insucesso clínico do psicanalista, dada a privacidade intrínseca de um diário; com a repetição oscilatória dos cuidados com a saúde, porque, para abandonar a terapia, Zeno precisa se manter convencido de que ela haveria lhe tornado menos saudável; e com a compulsão a escapar ao tédio do tempo da nota única que é derivado de tal abandono, pois o diário justamente é dedicado a uma tarefa que também opera como rivalidade edipiana contra o doutor S.

Com base na nossa investigação sobre o protagonista na primeira seção do diário e sobre a sua transição para narrador, completemos a nossa análise dessa seção abordando como a sua construção por Zeno na função de narrador contribui para estabelecer que a sua saúde não melhorou com a psicanálise. Começaremos essa etapa final examinando o trecho anterior ao início da narrativa da terapia, depois trataremos da desqualificação dos sonhos, da autobiografia e da acusação de omissão que faz Zeno interromper as sessões de psicanálise e, por fim, abordaremos o final da seção em análise.

De fato, a primeira seção do diário não inicia com a narrativa da terapia, pois o narrador faz com que o relato seja antecedido por uma dezena de parágrafos. Já tratamos dos dois primeiros ao examinarmos a transição de Zeno de protagonista para narrador: os períodos de abertura do diário são dedicados ao tempo da narração e nos informam que Zeno está abandonando a terapia e que está pior do que antes dela; no parágrafo seguinte, o narrador afirma que está mais doente do que nunca e atribui o agravamento da doença ao tratamento com o doutor S.; e expressa, com a ajuda de formulações hipotéticas quanto ao anúncio do abandono das sessões de psicanálise, o desejo de zombar do psicanalista e de bater nele. Logo, antes de qualquer relato sobre a terapia, Zeno abre o diário com uma avaliação inteiramente negativa sobre ela, que justamente é o último estado da relação que desenvolveu com o doutor S. e o tratamento. 
O diário prossegue com a ofensiva do narrador contra o doutor S. e a capacidade terapêutica das sessões de psicanálise, cuja abordagem sofre duas alterações. A primeira delas é a introdução das opiniões favoráveis que o próprio Zeno teve como protagonista sobre os dois objetos da ofensiva, mas segundo o esquema geral pelo qual tais opiniões serão tratadas pelo narrador, a saber, para imediatamente desautorizá-las. Assim, tanto a crença do protagonista no parecer do doutor S. de que estava curado é apresentada apenas para ser contradita pela constatação de que sentiu as dores surgidas na disputa de caricaturas contra Guido durante a terapia e ainda as sente (2004, p. 10481049) quanto o apreço que tinha pelas sessões é acompanhado pela sua desqualificação como ilusão tola e truque destinado a velhas histéricas e pela mais intensa manifestação de transferência negativa contra o psicanalista (2004, p. 1049). A segunda alteração é que a ofensiva contra a capacidade terapêutica passa a ser feita de modo complementar à inicial na medida em que o narrador deixa de insistir no agravamento da sua doença para argumentar que a terapia não melhorou a sua saúde, como ocorre no caso das dores que continua sentindo.

Nos parágrafos seguintes, o narrador aprofunda tal ofensiva complementar por meio da negação da melhora da saúde pela terapia objetando que ela não teve sucesso clínico; mais precisamente, apresenta objeções tanto contra o diagnóstico proposto pelo doutor S. (2004, p. 1049-1050), entre as quais inclui astutamente a própria constatação de que não está curado, quanto contra os principais elementos nos quais se baseia essa conclusão clínica, a saber, os sonhos e a autobiografia. A investida do narrador contra as bases do diagnóstico não só encerra o trecho do diário anterior ao começo da narrativa da terapia, mas também possui desdobramentos importantes dentro desse relato, de modo que trataremos a seguir numa análise única de todos os esforços do narrador para desqualificar os sonhos e a autobiografia.

A primeira base do diagnóstico que é explicitamente desqualificada pelo narrador é a autobiografia, a qual forneceria uma noção enganosa da vida de Zeno em razão da seleção baseada no contraste entre as suas competências linguísticas na fala do dialeto triestino e na escrita da língua italiana:

Il dottore presta una fede troppo grande anche a quelle mie benedette confessioni che non vuole restituirmi perché le riveda. Dio mio! Egli non studiò che la medicina e perciò ignora che cosa significhi scrivere in italiano per noi che parliamo e non sappiamo scrivere il dialetto. Una confessione in iscritto è sempre menzognera. Con ogni nostra parola toscana noi mentiamo! Se egli sapesse come raccontiamo con predilezione tutte le cose per le quali abbiamo pronta la frase e come evitiamo quelle che ci obbligherebbero di ricorrere al vocabolario! È proprio così che scegliamo dalla nostra vita gli 
episodi da notarsi. Si capisce come la nostra vita avrebbe tutt'altro aspetto se fosse detta nel nostro dialetto. ${ }^{89}$ (2004, p. 1050)

Além de questionar o diagnóstico, a desqualificação da autobiografia também serve para desautorizar a acusação de omissão do doutor S., o que o narrador efetivamente faz quando relata esse acontecimento que o fez interromper a terapia; mais precisamente, ele retoma o argumento linguístico da citação ao aplicá-lo às palavras em dialeto toscano e em línguas estrangeiras que são usadas para se referir às madeiras guardadas no depósito omitido (2004, p. 1060-1061). Logo, o argumento linguístico possibilita ao narrador superar dois fracassos do protagonista, o qual não conseguiu oferecer nenhum motivo para a omissão da qual foi acusado nem reaver o manuscrito autobiográfico que está com o doutor S. Além disso, o narrador reforça a superação do fracasso do protagonista no tocante à acusação de omissão finalizando o seu relato (2004, p. 1061) com outras investidas para desqualificá-la: em mais uma ocorrência da transferência negativa, supõe que o psicanalista não procurou esclarecimentos com outras pessoas por medo de que isso invalidasse o que Zeno chama de edifício de acusações e suspeitas, e recorre mais uma vez à resistência intelectual ao usar as noções de histeria e, implicitamente, de contratransferência na sugestão de que o fundamento do ódio do doutor S. esteja em ser um grande histérico por haver desejado a mãe em vão.

Quanto aos sonhos, a segunda base do diagnóstico que é explicitamente desqualificada pelo narrador, comecemos mencionando que uma primeira desqualificação já aparecera, ainda que de modo vago e enviesado, na seguinte declaração do narrador sobre o seu ato de escrita: "Almeno sono sicuro che questo è il vero sistema per ridare importanza ad un passato che più non duole [...]"90 $(2004, \mathrm{p}$. 1048). Sem nenhuma especificação ulterior, tal ausência de dor se aplica inclusive aos principais conteúdos do passado da história a ser narrada, a infância aludida pelos sonhos, e, portanto, estaria superada a condição do protagonista, o qual fícava encharcado de lágrimas com eles.

\footnotetext{
${ }^{89} \mathrm{O}$ doutor confia tanto nas minhas benditas confissões que não quer nem mesmo devolvê-las para que as reveja. Meu Deus! Ele só estudou medicina; por isso não sabe o que significa escrever em italiano para nós que falamos (e não sabemos escrever) o dialeto. Uma confissão escrita é sempre mentirosa. Mentimos em cada palavra toscana que dizemos! Podemos falar com naturalidade das coisas para as quais temos frases prontas, mas evitamos tudo quanto nos obrigue a recorrer ao dicionário! Dessa mesma forma, escolhemos de nossa vida os episódios mais notáveis. Compreende-se que ela teria uma feição totalmente diversa se fosse narrada em dialeto (2006, p. 391).

${ }^{90}$ Pelo menos estou seguro de que este é o verdadeiro sistema de reatribuir importância a um passado que já não dói [...] (2006, p. 389).
} 
Podemos comprovar o exercício do poder da escrita voltada a negar a dor que os sonhos causaram no protagonista no encerramento do trecho anterior à narrativa da terapia; com efeito, são alguns parágrafos (2004, p. 1050-1051) nos quais o narrador desqualifica sistematicamente, ainda que de formas equivocadas, as reações favoráveis que lhes tinha na condição de protagonista: torna incertas as lágrimas que eles causaram ao aludir à incapacidade de o próprio psicanalista diferenciar o sonho simulado dos demais; atribui a sensação de realidade que transmitiam a serem invenções tais como as da febre, pois não passavam de projeções provindas do seu intenso desejo de reproduzir imagens do passado; e desautoriza tanto a crença que tinha neles recorrendo ao modo apático pelo qual se recorda deles quanto as conclusões que o doutor S. obteve a partir deles reduzindo os mesmos à irrealidade ao caracterizá-los como meros signos gráficos ou esqueletos de imagens.

Quando finalmente narra os quatro sonhos que teve durante as sessões de psicanálise, Zeno acompanha o relato de cada um deles de algum indício de sua atual descrença neles. De fato, tanto a narração do primeiro é introduzida pela menção ao que induziu o protagonista a crer nele (2004, p. 1051), e a do terceiro é seguida pelo lamento por não crer mais neles (2004, p. 1054-1055) quanto, após o relato dos demais, efetivamente argumenta para desqualificá-los recorrendo à semelhança entre a mãe no sonho e no retrato que Zeno possui ao lado do leito no caso do segundo (2004, p. 1054) e à redução a uma variação infantil da manifestação onírica de Carla no caso do último (2004, p. 1055-1056). Quanto ao último trecho referido, notemos, de passagem, que o narrador desqualifica mais uma vez a autobiografia como base para a terapia com o doutor S. ao manifestar a sua surpresa com o fato de este não haver relacionado os sonhos com Carla e com a mãe.

Após a narrativa, que termina com a investida do psicanalista para que o protagonista retome a terapia argumentando que o paciente finalmente reconhecerá que a sua saúde melhorou com o tratamento, há apenas três parágrafos, nos quais o narrador afirma que a terapia lhe causou novas doenças, que está decidido a se curar dela e que evita os sonhos e as recordações (2004, p. 1064-1065), justamente os dois componentes nos quais se baseia o doutor S. para tratar Zeno. Logo, quem se revelou capaz de confrontar a investida final do psicanalista sobre o protagonista e de abandonar a terapia não foi ele próprio, mas o narrador, o que alude à própria instauração do narrador como instrumento para a obtenção do resultado final da rejeição da investida, conforme propusemos ao analisar a transição de Zeno de protagonista para autor do diário. 
Finalizemos a análise da construção da primeira seção do diário pelo narrador com a conclusão de que a interferência de Zeno na história relatada para estabelecer que a sua saúde não melhorou com a psicanálise gera dois resultados principais. O primeiro são as intromissões durante a narrativa pelas quais o narrador oferece oposição direta à terapia quando relata momentos nos quais o protagonista não o fez: os sonhos, a acusação de omissão e a investida final do doutor S. O segundo resultado é obtido impedindo que o diário inicie com Zeno simplesmente narrando a única fase do tratamento na qual poderia haver pensado que ele pudesse funcionar; em vez disso, Zeno começa o diário com um trecho de intensa oposição do narrador à terapia, que inclui a argumentação de que a crença inicial nela era ilusória, e, portanto, só narra a fase de aceitação inicial da terapia pelo protagonista após apresentar toda uma argumentação contra a terapia conduzida pelo doutor S. e contra as suas bases, que são os sonhos e a autobiografia.

Uma vez que terminamos a análise da primeira seção do diário, comentemos brevemente como a escrita da segunda seção serve para que Zeno continue a constituir o diário como um acúmulo polêmico contra a declaração do doutor $\mathrm{S}$. de que havia contribuído para melhorar a saúde do seu paciente. Comecemos pela apresentação da dúvida sobre um possível êxito terapêutico do psicanalista:

\begin{abstract}
In quel momento ricordai che fra le tante bugie che avevo propinate a quel profondo osservatore ch'era il dottor S., c'era anche quella ch'io non avessi più tradita mia moglie dopo la partenza di Ada. Anche su questa bugia egli fabbricò le sue teorie. Ma là, alla riva di quel fiume, improvvisamente, con spavento, ricordai ch'era vero che da qualche giorno, forse dacché avevo abbandonata la cura, io non avevo ricercata la compagnia di altre donne. Che fossi stato guarito come il dottor S. pretende? ${ }^{91}$ (2004, p. 1066)
\end{abstract}

O protagonista inicialmente desqualifica mais uma vez o doutor S. por ele não identificar as mentiras do seu paciente e depois nota que não trai Augusta há dias, talvez desde o abandono da terapia. É uma mudança surpreendente, pois não somos informados de nenhuma interrupção da série de traições iniciada com Carla e as prostitutas que a substituíram, de modo que seria o fim de uma repetição de muitos anos. De fato, o único acontecimento que nos é relatado e poderia justificar tamanha mudança é a terapia abandonada. O que nos interessa na presente seção do nosso

\footnotetext{
${ }^{91}$ Naquele momento, recordei que, entre tantas mentiras que preguei ao profundo observador que era o dr. S., havia também a de que eu não traíra mais minha mulher depois da partida de Ada. Até sobre esta mentira ele fabricou as suas teorias. Mas ali, à margem do rio, de repente, com surpresa recordei ser verdade que, desde há alguns dias, talvez desde aquele em que abandonara o tratamento, eu não tinha procurado a companhia de outras mulheres. Estaria curado como pretendia o dr. S. (2006, p. 405)?
} 
trabalho é que o protagonista conclui contra o que consideraria um êxito terapêutico do tratamento psicanalítico: ao acariciar uma camponesa chamada Teresina, Zeno sugere que atingiu a excitação sexual agradecendo por ainda não estar curado e declarando que cessou o tratamento a tempo (2004, p. 1069). As nossas considerações sobre a excitação com Teresina são bem diferentes, mas trataremos disso na próxima seção.

A terceira seção do diário também contribui para a argumentação de Zeno de que a terapia não melhorou a sua saúde, mas a oposição à capacidade terapêutica do tratamento com o doutor S. não é explícita como no caso da segunda seção, de modo que aguardaremos até estarmos em melhores condições para explicitar tal questão, o que só ocorrerá na terceira seção do presente trabalho.

4.2. A segunda seção e a adoção da forma temporal do diário de escrita casual: as mudanças na repetição do recalcado com a primeira cura parcial de Zeno

Nesta seção, investigaremos as mudanças na repetição do recalcado que são apresentadas na segunda seção do diário e as relações delas com a seção de abertura e com o diário como um todo. Para abordarmos a primeira parte da nossa investigação, começaremos tratando apenas do fim das repetições do aspecto fetichista do desejo de Zeno e depois proporemos que tal destino é comum a todas as repetições que dependem apenas do desejo pela mãe.

Comecemos a examinar o fim do fetichismo de Zeno observando que ele é apresentado na segunda seção do diário tanto no domínio diretamente sexual quanto na relação do sujeito com o tempo. Quanto ao declínio da sexualidade fetichista, a nossa análise se baseia na incapacidade inicial de Zeno se excitar com Teresina, seja porque o corpo da camponesa não está coberto por elementos que despertam o apetite sexual do protagonista, uma vez que ela não está usando sapatos, pó de arroz nem saia de crinolina (2004, p. 1067-1068), seja porque o rosto, os pés e as pernas que Teresina deixava à mostra eram da mesma cor por pertencerem todos ao ar livre (2004, p. 1068). A relação da mencionada ausência de maquiagem e de indumentária com a falta de excitação é obviamente compatível com o que conhecemos previamente sobre o desejo fetichista de Zeno, mas não podemos afirmar o mesmo no que tange às partes corporais 
ordinariamente expostas e de cor uniforme da camponesa. A própria referência aos pés nus de Teresina parece indicar esse duplo aspecto: por um lado, a ausência dos desejados sapatos; por outro lado, a presença do principal objeto do fetichismo do protagonista, os pés.

Para ambos os casos em análise, a narrativa favorece a contribuição da mudança ambiental da cidade para uma região rural, mas é difícil conciliar tal influência sobre a falta de excitação com a recuperação da mesma ao simplesmente acariciar o braço de Teresina (2004, p. 1068): de fato, esse ato não resgata nenhum elemento notório por ser uma fonte privilegiada de excitação de Zeno nem há indicação de retorno a uma situação urbana. Descartada da presente investigação, retomaremos a mudança ambiental num contexto mais abrangente na próxima seção deste trabalho. Em vez de entendermos que a ausência temporária de oportunidades impeça as repetições do fetichismo, a nossa proposta é de que estas acabaram porque o desejo de Zeno não é mais fetichista. Assim, propomos que a visão de pés ou pernas torna-se insuficiente como fonte da excitação do protagonista devido ao fim do fetichismo, pois não há mais partes do corpo feminino que são privilegiadas em detrimento das demais, e não por elas próprias, mas pelo objeto desejado que elas substituem. Logo, cada parte passa a ser valorizada em si, e não como mera substituta de outra; também deixa de haver uma divisão rígida em partes privilegiadas como substitutas e outras irrelevantes, de modo que a relação entre elas torna-se muito relevante, como no caso da uniformidade da cor da pele de uma camponesa.

Ora, a relação do sujeito com o tempo que é explorada no trecho anterior ao episódio com Teresina é compatível com a nossa proposta de que o fetichismo acabou na medida em que seria a projeção dessa mudança no desejo de Zeno sobre tal relação que resultaria na importância dada por ele à heterogeneidade das divisões temporais e dos momentos que constituem a sucessão temporal ainda que considerando apenas os mesmos objetos num fluxo exíguo de tempo.

Assim, quando Zeno narra a retomada do seu antigo costume de escolher datas para os últimos cigarros, lamenta a desordem do tempo devido à variação na quantidade de dias entre meses consecutivos (2004, p. 1065). Depois de tantos anos pensando em datas para parar de fumar, é notável que só então essa variação se torne relevante para o vício de Zeno, o que expressa uma importante mudança na sua relação com o tempo, devido à qual não é mais insensível à heterogeneidade entre as divisões temporais.

De modo equivalente, é destacada a diversidade dentro da própria constituição 
do fluxo temporal ao enfatizar a mudança incessante na aparência dos objetos mais triviais: "l'acqua corrente [do rio Isonzo] fornisce lo svago che occorre perché non è uguale a se stessa nel colore e nel disegno neppure per un attimo. [...] Certamente in alto soffiava un forte vento perché le nubi vi mutavano continuamente di forma [...]"92 (2004, p. 1065-1066). A nossa compreensão do trecho citado parece ser reforçada por uma possível referência implícita à antiga filosofia grega no período sobre a água, que lembra imediatamente uma das sentenças mais célebres do filósofo Heráclito, o qual entendia a natureza em termos de mudança e multiplicidade e se opunha à escola eleática, que, por sua vez, tinha entre os seus principais representantes Zenão, cuja filosofia justamente é conhecida pelos paradoxos sobre o movimento e cujo nome remete imediamente ao do protagonista, de modo que Svevo poderia haver alusivamente sintetizado a transformação em curso de Zeno na oposição entre os filósofos aos quais remetem implicitamente o nome do protagonista e a observação que ele faz sobre a água corrente do rio.

Uma vez que analisamos o fim do fetichismo de Zeno, ampliemos a nossa investigação para verificar se não há outras repetições que são encerradas na segunda seção do diário. Retomando a relação do sujeito com o tempo nesse novo contexto, podemos constatar que a diversidade destacada nessa relação também se opõe às repetições da unidade e da totalidade que caracterizam o desejo de Zeno pela mãe. $\mathrm{O}$ fim de tais recorrências é abordado de modo mais direto no parágrafo seguinte às observações sobre a água do rio e as nuvens (2004, p. 1066), no qual Zeno também reconhece a mudança incessante na própria história dos seus relacionamentos eróticos, marcados pelo desejo de partes das diferentes mulheres com as quais se envolveu: em oposição aos trechos nos quais o protagonista valoriza decisivamente o amor por uma mulher única e inteira, dos quais tratamos na seção inicial do segundo capítulo, Zeno reage positivamente à lembrança da diversidade de mulheres que desejou fragmentariamente.

Além das repetições cujo final é abordado na segunda seção do diário, nenhuma das demais que estudamos nas séries básicas que derivam do desejo pela mãe voltam a aparecer nas três últimas seções do diário: o ato de mancar, o sorriso materno e as expressões da sexualidade oral, como o canibalismo. Mais do que isso, propomos que

\footnotetext{
92 [...] a água corrente [do rio Isonzo] fornece a distração que surge porque nunca é igual a si mesma na cor e no desenho, nem mesmo por um átimo. [...] Certamente no alto soprava um vento forte, pois as nuvens mudavam continuamente de forma [...] (2006, p. 404).
} 
encerraram todas as repetições que dependem apenas do desejo pela mãe. Para que compreendamos melhor como o texto elabora o término generalizado dessas recorrências, examinemos o final do episódio com Teresina.

Imediatamente antes de Zeno obter a excitação buscada acariciando o braço da camponesa, há o inusitado trecho propiciado por um burrico: "Allungò il muso ed emise il suo grande grido d'amore [...]. Come varca le distanze e com'è significante con quel primo grido che invoca e si ripete, attenuandosi poi e terminando in un pianto disperato. Ma sentito così da vicino, mi fece dolere il timpano"93 (2004, p. 1068). Propomos que o zurro é, ao ser qualificado de grande, a expressão sonora de intensidade máxima para um burro e representa, ao ser suposto como de amor, a expressão mais intensa desse sentimento em Zeno, ou seja, o amor pela mãe. Considerando também que o período seguinte da citação inicia por uma transposição espacial de um intervalo temporal, ponderamos que a descrição de Zeno ressoa o grande amor pela mãe atravessando os anos e repetindo-se com menor intensidade com outras mulheres. Além disso, a tristeza resultante do fim da repetição também é válida para ambos os casos. Por fim, aquele que finalmente "escuta" o seu inconsciente - que tal como o burrico está fora do domínio da razão - termina por ser atingido pela dor que evitara até então.

Da nossa proposta de que as repetições do desejo pela mãe terminaram resulta que a excitação sexual com Teresina seria a primeira experiência do protagonista nesse campo na qual é superada a sexualidade forjada na sua infância, o que também elucidaria como a puberdade da camponesa contribui para a construção do sentido do relato, dado que essa é a fase na qual geralmente se tem a experiência mencionada. Consideramos também que a nova sexualidade de Zeno, por estar finalmente liberada de conflitos psíquicos, encontra expressão no duelo verbal (2004, p. 1069) que encerra o episódio com Teresina, pois nem mesmo a recusa sexual da camponesa é capaz de impedir o tom de satisfação que se instala com os risos, a alegria de Zeno e os gritos no final do duelo e que culmina com a seguinte síntese da condição do protagonista: "Urlavo, compiacendomi del mio spirito che veniva direttamente dal mio sesso"94 (2004, p. 1069).

Ora, segundo as considerações que fizemos sobre o final do episódio com

\footnotetext{
93 Ergueu o focinho e emitiu um grande zurro de amor [...]. Como transpõe a distância e como é significativo aquele primeiro grito que invoca e se repete, atenuando-se depois e terminando num pranto desesperado. Mas, ouvido assim de tão perto, fez-me doer os tímpanos (2006, p. 407).

${ }^{94}$ Eu berrava, satisfeito com aquele humor que me vinha diretamente do sexo (2006, p. 408).
} 
Teresina, a excitação sexual com a camponesa não é uma retomada da série das traições que Zeno iniciou com Carla. O término dessa série é condizente com nossa proposta de que encerraram todas as repetições que dependem apenas do desejo pela mãe, pois, conforme analisamos no segundo capítulo, as traições com Carla eram repetições oscilatórias que estavam baseadas no conflito gerado por desejar tanto Ada quanto a amante, ambas substituitas edipianas da mãe.

Com base nos resultados da nossa investigação sobre as mudanças na repetição do recalcado que são apresentadas na segunda seção do diário, tratemos das relações dessas modificações com a seção de abertura e com o diário como um todo. Quanto à primeira delas, retomemos a resposta de Zeno contra a investida final do doutor S., o qual declarava que havia contribuído para melhorar a saúde do seu paciente. Após abordarmos o fim de tantas repetições, consideramos que a saúde do protagonista melhorou a ponto de podermos falar em uma cura parcial. Além disso, o único acontecimento recente da história de Zeno que nos parece capaz de efetuar essa cura é o tratamento com o doutor S. Logo, concordamos com a declaração do psicanalista, o que é uma imensa mudança em relação ao fracasso terapêutico que é expresso pela história e pela escrita da primeira seção do diário; devemos, entretanto, assinalar que a sua investida fracassa, pois a saúde de Zeno melhora sem que ele reconheça essa mudança e, portanto, não há a retomada da terapia conforme previsto pela investida.

Qualificamos a cura do protagonista na segunda seção de parcial por duas razões prinicipais. A primeira delas é que, apesar do fim das repetições, toda a história das suas ocorrências permanece sob o domínio do recalque, pois, ainda que Zeno passe a aceitar a história dos seus relacionamentos eróticos, não demonstra nenhum reconhecimento do fetichismo, do canibalismo e dos demais aspectos que constituíam o seu desejo edipiano, o que o impede, inclusive, de compreender a novidade da sua excitação por Teresina. A segunda razão para qualificarmos a cura em análise de parcial é que as repetições da rivalidade edipiana não terminaram, o que exploraremos na próxima seção do presente capítulo. Notemos que as duas razões estão ligadas na medida em que é justamente a concepção de Zeno de que a excitação por Teresina seria uma mera retomada da série de traições da esposa que lhe permite declarar que parou a terapia antes de ser curado e, portanto, refutar novamente a investida final do doutor S.

A fim de analisarmos a relação das mudanças na repetição do recalcado que são apresentadas na segunda seção com o próprio diário ao qual pertence, precisamos tratar inicialmente de um componente da relação entre duas partes nas quais o romance 
divide a escrita de Zeno: a autobiografia e o diário. Mais precisamente, há uma ruptura temporal entre essas partes, como já está indicado pelos próprios hiatos temporais que as separam, os da história e da narração. O primeiro deles ocorre porque, na segunda parte, Zeno se dedica a relatar acontecimentos recentes, ocorridos, no máximo, há alguns meses, e, portanto, cancela a narração do seu passado remoto, iniciada no terceiro capítulo. Como os acontecimentos contados no fim da autobiografia são de 1895 e a primeira data registrada no diário é de 1915, há um hiato de aproximadamente vinte anos. O segundo hiato é explicitado no início do diário, quando Zeno declara que não escrevia há um ano (2004, p. 1048).

Por ora, o que nos interessa na ruptura temporal que é anunciada pelos hiatos temporais que identificamos está na mudança entre as configurações temporais dos capítulos da autobiografia e das seções do diário. No capítulo anterior, expusemos como a divisão em capítulos estava baseada, em grande medida, no modelo da vida burguesa, de modo que constituíam etapas temporalmente sucessivas que estavam ligadas em termos de causalidade e expectativas segundo esse modelo. No caso do diário, as suas divisões não ganham nenhum título, sendo identificadas apenas pelas datas nas quais foram escritas, de modo que tal segmentação não adota nenhum modelo que oriente a narrativa em termos causais e de expectativas e que impeça o esvaziamento da cronologia numa pura sucessão. Além disso, o acaso de tal sucessão é reforçado por não se tratar em nenhum momento de um diário no sentido estrito de haver anotações para dias praticamente consecutivos; pelo contrário, as seções sempre estão separadas por mais de uma semana, e os saltos entre elas são de duração bastante variável: menos de duas semanas, mais de um mês e mais de meio ano. Aproveitemos para ressaltar que a seção final é uma carta, no sentido de que é escrita para ser lida por um interlocutor específico (2004, p. 1081), mas propomos que alguns dos seus aspectos ainda operam como nas divisões anteriores do capítulo e consideramos somente a eles por ora, deixando para tratar ulteriormente das novidades trazidas pela carta.

Voltamos a encontrar a mudança que analisamos no parágrafo anterior, no qual nos restringimos ao âmbito do processo de divisão da autobiografia e do diário, quando tratamos do âmbito do produto resultante da divisão em cada caso. No capítulo anterior, exploramos a tendência de cada capítulo da autobiografia a tentar adotar, em termos da sua organização geral, uma temporalidade linear na medida em que a cronologia predomina como andamento da narrativa, supostas causas proliferam e há uma elaboração das expectativas, que privilegiam as questões inerentes ao modelo da vida 
burguesa. No caso do diário (e da carta), a identificação da seção por uma mera data já retira a orientação básica das expectativas que o título do capítulo propicia: por exemplo, intitular a primeira seção de abandono ou fracasso da terapia teria um efeito muito parecido com o título dado ao capítulo sobre a morte do pai.

Mais decisiva é a fragmentação extrema das seções devido à história de cada uma delas ser dedicada a um único dia - com exceção da primeira, que ganha, portanto, um caráter de transição entre a autobiografia e o diário. Sem uma organização geral que remeta a um modelo prévio de causas e expectativas e com o relato sucinto sobre o reduzido intervalo de um dia, o texto deveria ser composto com a determinação de reconstituir as carências causais e expectantes para que esboçasse adotar uma temporalidade linear, como seria o caso de um diário no qual acompanhássemos os êxitos e as dificuldades de um projeto de ação ou de escrita, mas nada disso ocorre nas seções posteriores ao abandono da terapia: até surgir a dúvida sobre estar curado das traições, o passeio de Zeno acontece a esmo, e o duelo verbal que encerra o episódio com Teresina extrapola a resolução dessa dúvida; a exposição do esforço do protagonista para reencontrar a família após o início da guerra não impede que o resultado do relato seja um acúmulo de situações absurdas; e o anúncio do narrador de que está curado não só se torna enigmático tão logo Zeno identifique a saúde a uma convicção e simplesmente se declare curado com uma vitória comercial, mas também é incapaz de servir de base causal e das expectativas para as reflexões finais sobre a saúde no que tange à vida em geral e ao futuro da humanidade.

Com base nas nossas considerações sobre a temporalidade linear ser abandonada no nível geral da mera sucessão das datas do diário e da carta e reduzida drasticamente em cada uma das três seções finais do último capítulo, concluímos que ela se torna residual e não é mais capaz de sustentar um embate com a temporalidade de onda, de modo que essas seções não apresentam as duas configurações temporais da autobiografia que expusemos no final da segunda seção do capítulo anterior: desaparecem tanto a configuração que era própria ao ponto de vista de Zeno, a do embate mencionado, quanto o fracasso da imposição da linearidade temporal ao texto, que é o momento negativo da segunda configuração. Logo, resta apenas a afirmação geral da temporalidade de onda, a qual passa a constituir a experiência temporal do ponto de vista de Zeno, ou seja, resta uma sucessão de acontecimentos para a qual, de modo geral, não se tenta apresentar as causas que a constituiriam nem as expectativas que os antecederiam. De fato, as três seções finais nos confrontam com acontecimentos 
inesperados - um passeio no campo, a interrupção das traições do protagonista, o início de uma guerra, a cura pelo comércio e a carta do doutor S. - e as reações inusitadas de Zeno, as quais são pouco justificadas pelo relato e esclarecem pouco os acontecimentos mencionados.

Especificada a mudança entre as configurações temporais dos capítulos da autobiografia e das seções de um diário de escrita casual, encerremos a presente seção verificando como ela está relacionada com as mudanças na repetição do recalcado que avaliamos como sendo uma cura parcial de Zeno. Principiemos observando que o diário e a cura surgem em momentos muito próximos. O que permite ligá-los temporalmente é o abandono da terapia. Quanto ao diário, já comentamos na seção anterior que ele inicia com o anúncio desse abandono ao passo que Zeno ainda postergava o retorno à terapia no dia anterior ao qual começou a escrevê-lo (2004, p. 1048). No tocante à cura, Zeno declara que o fim das traições, que é o seu primeiro indício, talvez haja ocorrido no mesmo dia no qual abandonou o tratamento (2004, p. 1066). Assim, o texto traz a sugestão de que o diário e a cura haveriam começado no mesmo dia.

O início concomitante do diário e da cura parcial de Zeno é facilmente inteligível com base nos resultados que obtivemos na presente seção, pois o fim das repetições que dependem apenas do desejo pela mãe provoca efeitos equivalentes sobre a observação da natureza pelo protagonista e sobre a relação de Zeno com o tempo. Já comentamos a dificuldade do narrador com a divisão do ano em meses, dos quais destaca a desigualdade na duração. Do modo equivalente, Zeno não consegue mais nem dar um esboço de temporalidade linear ao que relata após o fim das repetições edipianas de fetichismo, unidade e totalidade, o que resulta no amplo domínio da temporalidade de onda, cuja expressão mais explícita são as datas do diário e da carta. Precisamos ressalvar apenas que a primeira seção ainda apresenta um embate entre essas temporalidades, seja porque o próprio processo de cura ainda está em transição durante a escrita dessa seção, seja por retomar a história de Zeno antes da sua transformação pela cura parcial.

\subsection{A seção final do último capítulo como carta hostil para o rival: a segunda cura parcial de Zeno e as mudanças ambientais e na repetição do recalcado}


A presente seção é dedicada à análise das mudanças na repetição do recalcado que são apresentadas na última seção do capítulo que encerra o romance, que é escrita como uma carta no sentido de que é destinada para a leitura do doutor S. Tal como na segunda seção, o elemento crucial para a nossa análise é uma cura parcial do protagonista. Assim, como introdução à abordagem das últimas modificações na repetição do recalcado no romance, faremos uma apresentação inicial da segunda e última cura de Zeno e investigaremos como as mudanças ambientais operam no âmbito terapêutico desde a primeira cura parcial.

$\mathrm{Na}$ quarta seção, é o próprio Zeno que se declara curado e identifica o comércio como sendo a causa da cura (2004, p. 1082). Verifiquemos melhor no que consiste essa inaudita terapêutica mercantil. Na ausência da família, de Olivi e dos melhores empregados devido à guerra (2004, p. 1070), Zeno ganha uma liberdade inédita e finalmente assume a administração da empresa herdada do pai. Além disso, a guerra mudou o comércio a tal ponto que Zeno fala como se ele estivesse morto e que os conselhos de um comerciante experiente se tornam estranhos (2004, p. 1082). Nessa situação radicalmente alterada, o protagonista, que não tem as habilidades exigidas para o comércio, atua de um modo que os bons comerciantes reprovariam (2004, p. 10821083): só consegue assumir riscos incomuns porque se trata de uma oportunidade única na qual Olivi não está presente para impedi-lo, compra num sentido diferente dos comerciantes e a sua principal transação está baseada num argumento - o uso do incenso como substituto da resina - que um vendedor usa para enganá-lo. O protagonista aposta que esse argumento, certamente falso numa situação de paz, pode tornar-se verdadeiro durante uma guerra, o que efetivamente acontece.

Ao passo que mudanças tão grandes tornam compreensível que o protagonista consiga assumir o pleno controle da empresa herdada do pai e auferir lucros, o efeito terapêutico que Zeno atribui a essa vitória comercial não é nada trivial nem ganha uma explicação efetiva. Apesar de Zeno não explicitar a associação desses acontecimentos com as tentativas de assumir os negócios que eram do pai, não deveríamos ter dificuldade, uma vez que fazemos tal associação, em reconhecer que a vitória do protagonista não é apenas comercial, pois é também a primeira dessas tentativas que é bem-sucedida e, portanto, Zeno finalmente alcança algo que buscou durante mais de duas décadas, a vitória sobre o pai. Que ela também seja uma cura, eis o que sustentaremos ao tratar dessa transformação ao longo da presente seção. 
Antes de prosseguirmos o nosso estudo da quarta seção, tratemos de uma dúvida que poderia ser suscitada pela importância crucial que a guerra tem para que Zeno finalmente alcance a vitória sobre o pai: a primeira cura parcial também não seria apenas um efeito de uma mudança ambiental, a da cidade para o campo, em vez de ser causada pela terapia com o doutor S.? Afinal, Zeno insiste sobre os problemas que os costumes do campo trazem para a prática habitual da sua sexualidade (2004, p. 10671068), tais como a dificuldade para encontrar prostitutas e a falta de rostos empoados e de membros femininos cuja coloração não seja uniforme ao resto do corpo e cuja exposição completa seja evitada pela crinolina e por calçados.

Consideramos que a terceira seção do diário, que separa as duas curas de Zeno, seja uma resposta a uma excessiva valorização da mudança ambiental no que se refere à capacidade de transformar os indivíduos. Comparando com a seção seguinte, a guerra altera radicalmente o ambiente em ambas, mas Zeno não é modificado no caso da terceira. Este contraste de um indivíduo inalterado no contexto de um ambiente transformado é sutilmente sintetizado na correção do narrador sobre o que qualifica como novo: "Da un giorno all'altro io fui un uomo del tutto nuovo, anzi, per essere più esatto, tutte le mie ventiquattr'ore furono nuove del tutto"95 (2004, p. 1070). De fato, a terceira seção justamente destaca que, apesar de toda a gama de comportamentos agressivos proporcionados pela guerra, o protagonista não participa de nenhum deles. Isso é elaborado mais explicitamente no trecho no qual ele encontra os militares do exército austríaco (2004, p. 1075-1077). Assim, ainda que Zeno esteja desarmado e seja apenas um civil inofensivo, sofre ameaças de atirarem nele e é tratado com rudeza desmedida por meio de gritos e zombarias, inclusive sendo ofendido sem reservas pelo oficial austríaco. Apesar de não estar em condições de ser propriamente agressivo, um grande contraste é criado porque o protagonista não expressa nenhuma agressividade, que seja, mesmo uma única vez, dizer uma palavra mais ríspida, elevar o tom de voz ou protestar pelo tratamento rude; pelo contrário, age até mesmo com desnecessária consideração e brandura.

Zeno não participa da tendência a manifestar mais abertamente a agressividade que a guerra proporciona porque continua limitado à hostilidade velada que restringe a sua relação com os rivais edipianos. A sua recusa das agressões declaradas, que são intrínsecas a um conflito bélico, é de tal ordem que ele se entrega a uma sistemática

\footnotetext{
${ }^{95}$ De um dia para o outro, eu era um homem totalmente diferente, ou, para ser mais exato, todas as minhas 24 horas foram inteiramente diversas (2006, p. 409).
} 
negação da guerra, a qual perpassa a terceira seção. Citemos alguns exemplos desse comportamento de Zeno, começando pelos que negam diretamente a guerra: a atitude de ouvir as histórias sobre ela sem se preocupar que pudesse ser alcançado pelo conflito (2004, p. 1070); as conversas com o pai de Teresina (2004, p. 1073-1074) e com o cabo (2004, p. 1078), nas quais sustenta que a Itália não entrará no confronto; o pensamento de que, apesar das ameaças, os países não chegariam ao enfrentamento (2004, p. 1079); e a ideia otimista e infantil de que a paz poderia ser refeita porque ninguém morrera ainda na fronteira (2004, p. 1081).

Há também trechos nos quais o conflito é negado indiretamente, principalmente por meio de comportamentos que seriam normais ou até banais numa época de paz, mas tornam-se absurdos numa situação bélica. Dentre essas negações indiretas, citamos os seguintes exemplos: a insistência de Zeno em voltar para casa a fim de tomar o café da manhã ou de buscar o casaco e o chapéu (2004, p. 1074-1078), o que exigiria passar entre os exércitos dos dois países; a intenção de protestar com o burgomestre pelo modo como foi tratado pelos militares, cuja preparação para o combate ele está atrapalhando, que ocorre a Zeno tanto após a primeira ameaça que sofre de um soldado (2004, p. 1075) quanto após se afastar do pelotão (2004, p. 1079); e a recusa de Zeno até mesmo a contar as suas experiências com os militares durante a viagem para Trieste, o que justifica sob o pretexto de comunicá-las apenas a conhecidos da sua cidade (2004, p. 1080).

Esse descompasso de um indivíduo que está mergulhado num ambiente dominado pela agressividade e, ao mesmo tempo, parece ser incapaz de agir ou falar de modo agressivo está sintetizado na imagem exposta quase ao final da terceira seção: "La notte era illuminata dal bagliore di molti incendi e un amico che mi vide andare verso casa mia in maniche di camicia mi gridò: - Hai preso parte ai saccheggi?"96 (2004, p. 1081). Em vez de estar protegido e isolado dentro de casa, o protagonista está sem uma indumentária burguesmente civilizada e mergulhado num ambiente de incêndios e saques sem estar envolvido em nada disso...

Com base na nossa análise sobre a terceira e a quarta seções do capítulo final, concluímos que a mesma mudança ambiental - a guerra - pode ou não causar a transformação do protagonista e, portanto, as duas curas de Zeno não podem serem atribuídas a alterações no ambiente sem considerações mais pormenorizadas. Para o

\footnotetext{
${ }^{96}$ A sombra iluminava-se pelo resplandecer de muitos incêndios e um amigo que me viu seguir para casa em mangas de camisa gritou: - Você esteve no saque (2006, p. 418)?
} 
presente trabalho, é de pouca relevância se a cura pelo comércio depende apenas da guerra ou também da terapia com o doutor S. ou do fim de algumas repetições que examinamos na seção anterior; nos importa apenas que essa conclusão apoia a nossa análise de que a primeira cura de Zeno inicia no mesmo dia que o abandono da terapia e, portanto, antes do passeio no campo, o qual completa o processo de cura ou talvez apenas antecipe o que ocorreria de modo mais lento mesmo sem uma mudança ambiental.

Uma vez que fizemos as nossas considerações iniciais para a presente seção, investiguemos as modificações nas repetições do recalcado de Zeno após a vitória no comércio e como elas se relacionam com a segunda cura e com o próprio ato de escrever de Zeno. Começaremos tratando desses temas na medida em que as repetições do recalcado terminam e depois abordaremos em que sentido elas e o próprio recalcado permanecem, e o que isso acarreta para a segunda cura.

Na seção anterior, expusemos como a primeira cura parcial está associada ao fim de repetições do desejo de Zeno pela mãe; de modo equivalente, propomos que a segunda cura está associada ao fim de repetições da rivalidade edipiana, a começar obviamente pelo término das iniciativas para assumir os negócios e desbancar o rival Olivi, já que Zeno finalmente teve êxito nesse propósito. Além dessa, há outras cujo final podemos verificar com base no que Zeno escreve: a hostilidade velada, os cuidados com a saúde e a competição segundo a atividade profissional de um médico, o doutor S.

Quanto à hostilidade, ela deixa de ser velada para se tornar declarada. Em contraste com as demonstrações de cortesia e a negação da guerra da terceira seção, Zeno é declaradamente hostil contra um rival - o doutor S. - e aborda explicitamente a rivalidade entre os homens ao escrever pela última vez no romance. Para destacarmos como Zeno se torna abertamente hostil ao doutor S., exploremos as três relações que são produzidas entre eles pela atividade da escrita. A primeira relação é produzida pelo manuscrito autobiográfico, o qual é destinado à leitura do psicanalista desde o princípio e cujas centenas de páginas trazem poucas referências a ele, sendo que nenhuma das quais o critica diretamente. A segunda relação é produzida pelas três primeiras seções do diário, as quais não estavam destinadas a serem lidas pelo doutor S., o qual é recorrentemente tratado nelas, principalmente na primeira seção, com termos ofensivos e com atitudes e ponderações pelas quais é ridicularizado, ou seja, com manifestações de transferência negativa - como já analisamos neste capítulo. Além disso, a capacidade 
terapêutica do psicanalista é diretamente afrontada por Zeno, seja pela negação que faz nas duas primeiras seções de que haja sido curado, seja pela alegação de desprezo pela cura numa situação de guerra (2004, p. 1070-1071). Por fim, eis como o paciente apresenta a sua derradeira produção escrita:

Ecco che dalla Svizzera il dr. S. mi scrive pregandomi di mandargli quanto avessi ancora annotato. È una domanda curiosa, ma non ho nulla in contrario di mandargli anche questo libercolo dal quale chiaramente vedrà come io la pensi di lui e della sua cura. Giacché possiede tutte le mie confessioni, si tenga anche queste poche pagine e ancora qualcuna che volentieri aggiungo a sua edificazione..$^{97}$ (2004, p. 1081)

Por meio desse trecho inicial da quarta seção do último capítulo, constatamos que a terceira relação produzida entre o doutor S. e o seu paciente pela atividade da escrita é um híbrido das duas anteriores, pois Zeno escreve expressamente para o psicanalista como na primeira relação e não o poupa das expressões de hostilidade, a começar por aquelas que já estavam nas seções anteriores e que Zeno concorda em lhas enviar, como na segunda relação, inclusive reiterando a negação da eficácia terapêutica do tratamento psicanalítico, dado que considera que foi curado pelo comércio, como já comentamos.

Além de ser declaradamente hostil ao doutor S., Zeno escreve mais uma vez justamente com esse objetivo. Para começar, suspeitamos que a própria existência de uma quarta seção depende da mudança da hostilidade: há um considerável hiato temporal entre as três seções iniciais e a última, uma vez que Zeno permanece muitos meses sem escrever no seu manuscrito (a data final é de 24 de março de 1916) depois de fazê-lo três vezes em menos de dois meses (de 3 de maio a 26 de junho de 1915), de modo que talvez não escrevesse a seção final se não surgisse a oportunidade de exercer a hostilidade declarada respondendo à carta do psicanalista.

Também consideramos que o próprio objetivo de Zeno ao escrever a seção final é ser declaradamente hostil ao doutor S. com base no contraste dos dois efeitos principais que a história narrada tem para ele: ao contrário do protagonista que não sabe que a cura pelo comércio também é a vitória tão desejada sobre o pai, o narrador sabe que essa cura também é a vitória sobre o psicanalista, já que não precisa mais da terapia nem foi ela que o curou. Finalmente, acrescentemos o propósito apresentado por Zeno

\footnotetext{
${ }^{97}$ Eis que me escreve da Suíça o dr. S. pedindo-me que lhe mande tudo quanto eu tenha anotado. Trata-se de um pedido curioso, mas nada tenho contra o fato de lhe mandar este livrinho no qual verá claramente o que penso dele e do seu tratamento. Já que está de posse de todas as minhas confissões, que tenha também estas poucas páginas e algumas outras que eu venha a acrescentar para a sua edificação (2006, p. 418419).
} 
no final do trecho da última citação, quando, em detrimento de continuar a escrever sobre a própria história, se propõe a edificar o doutor S., pois tal propósito é outra ocorrência da hostilidade declarada, como concluiremos na continuação da análise do fim das repetições. Em suma, a escrita de Zeno deixa de ser um registro íntimo de diário, como ocorria nas seções anteriores do capítulo final, para se tornar um instrumento da rivalidade declarada na forma de uma carta destinada ao maior dos seus rivais operantes após a vitória pelo comércio, o doutor $\mathrm{S}$.

Além da hostilidade declarada a um rival específico, Zeno expõe claramente a presença da competição e da agressividade na espécie humana como um todo nos últimos parágrafos do romance (2004, p. 1084-1085). A abordagem da rivalidade num âmbito público ocorre inicialmente com a ameaça de superpopulação e depois com os artefatos de destruição em massa, quando Zeno atinge o ápice em termos de agressividade ao expor a hipótese de que um único homem, após a invenção de um explosivo incomparável, destrua toda a vida conhecida.

No tocante ao fim dos cuidados com a saúde, ela fica patente quando comparamos o longo histórico dessa repetição, que apresentamos na seção sobre repetições oscilatórias no segundo capítulo, com a nova concepção de Zeno sobre a saúde e a doença, conforme ele expõe nos seguintes trechos:

\begin{abstract}
Intanto egli [o doutor S.] crede di ricevere altre confessioni di malattia e debolezza e invece riceverà la descrizione di una salute solida, perfetta quanto la mia età abbastanza inoltrata può permettere. [...]

Io soffro bensì di certi dolori, ma mancano d'importanza nella mia grande salute. Posso mettere un impiastro qui o là, ma il resto ha da moversi e battersi e mai indugiarsi nell'immobilità come gl'incancreniti. Dolore e amore, poi, la vita insomma, non può essere considerata quale una malattia perché duole. [...]

Naturalmente io non sono un ingenuo e scuso il dottore di vedere nella vita stessa una manifestazione di malattia. La vita somiglia un poco alla malattia come procede per crisi e lisi ed ha $\mathrm{i}$ giornalieri miglioramenti e peggioramenti. A differenza delle altre malattie la vita è sempre mortale. Non sopporta cure. Sarebbe come voler turare i buchi che abbiamo nel corpo credendoli delle ferite. Morremmo strangolati non appena curati. ${ }^{98}$ (2004, p. 1082-1084)
\end{abstract}

\footnotetext{
${ }^{98}$ Ele [o doutor S.] estará à espera de receber outras confissões de minha doença e da minha fraqueza e, em vez disso, receberá a descrição de uma saúde sólida, perfeita, tanto quanto a minha idade avançada o permite. [...] É verdade que ainda sofro de algumas dores, mas de nenhuma importância no quadro de minha grande saúde. Às vezes ponho um emplastro aqui ou ali, mas o resto se move e luta, jamais se entregando à imobilidade dos esclerosados. Dor e amor; portanto a vida, em suma, não pode ser considerada uma doença pelo simples fato de doer. [...] Naturalmente não sou ingênuo e desculpo o doutor que vê na própria vida uma manifestação da doença. A vida assemelha-se um pouco à enfermidade, à medida que procede por crises e deslizes e tem seus altos e baixos cotidianos. À diferença das outras moléstias, a vida é sempre mortal. Não admite tratamento. Seria como querer tapar os orifícios que temos no corpo, imaginando que sejam feridas. No fim da cura estaríamos sufocados (2006, p. 419420).
} 
Propomos que a concepção resultante dessas considerações de Zeno é a de que a saúde e a doença são inseparáveis. De fato, os últimos períodos da citação consideram que um organismo que não tenha doença tampouco pode ter saúde, ou seja, está morto. Estando vivo, o organismo tem simultaneamente doença e saúde, e Zeno explora os limites da distribuição de ambas: por um lado, um organismo cuja saúde seja máxima, ainda assim possui alguma doença, de modo que Zeno pode afirmar que está perfeitamente saudável ainda que acrescente a ressalva dos problemas próprios da sua idade; por outro lado, um organismo cuja doença seja máxima ainda assim possui alguma saúde para estar vivo, como é o caso daqueles que estão enfermos a ponto de não conseguirem se mover nem lutar para continuar a viver. Logo, tudo se torna uma questão de grau, e o que importa não é não ter nenhuma doença, mas manter-se afastado daquelas graves, que provocam restrições severas. Até mesmo a piora de saúde deixa, em geral, de ser alarmante, pois é esperado que a distribuição seja variável, resultando em crises e recuperações que se sucedem em períodos irregulares. Compreensivelmente, a seção em análise não traz menção à repetição oscilatória de cuidados com a saúde, dependente de um conflito inexistente na nova concepção.

A concepção da saúde e da doença como inseparáveis também aparece nos parágrafos finais do romance, tanto de modo localizado quanto como influência global. No primeiro caso, há os homens que hipoteticamente inventariam um explosivo incomparável e o usariam para destruir o planeta (2004, p. 1085), pois a ideia de que eles, apesar de acabarem com toda a vida conhecida, não seriam especialmente doentes rejeita que a relação entre as duas noções seja de exclusão mútua na medida em que o fim total da saúde não é causado por nenhum ápice da doença. É também o caso da conclusão sobre a destruição do planeta, quando o raciocínio segundo o qual um organismo que não tenha doença tampouco possa ser sadio é expandido para o planeta inteiro, pois a explosão acaba não só com os parasitas e as moléstias, mas também com a existência da própria saúde.

Quanto ao segundo caso, comecemos notando que, finalmente rompida a oscilação dos cuidados com a própria saúde, Zeno então se permite considerar as doenças da espécie humana. É certo que não se ocupa de quaisquer doenças: em conformidade com a sua nova concepção, Zeno só se dedica a graves ameaças à vida. Esse grau de gravidade é até mesmo mencionado no começo da apresentação da primeira delas, a da degradação ambiental, quando afirma que a vida está contaminada até as raízes (2004, p. 1084). Apesar disso, essa nem mesmo é a mais perigosa das 
ameaças, pois ainda mais perigosa é aquela que serve de base para a hipótese da destruição do planeta pelo explosivo incomparável, a dos artefatos (2004, p. 10841085). Conforme Zeno, a humanidade trocou a seleção natural pela seleção segundo a posse dos artefatos, a qual causa a proliferação sistemática das moléstias e, portanto, um desequilíbrio cada vez maior na distribuição entre a saúde e a doença. Logo, a posse dos artefatos como critério seletivo da evolução biológica constitui uma ameaça crescente à própria manutenção da espécie.

Por fim, acabam as repetições das competições desvantajosas para Zeno por serem numa área de destaque potencial ou efetivo do rival, pois elas são substituídas por vitórias. Assim, a vitória no comércio implicitamente põe fim a uma longeva competição, a das iniciativas para assumir os negócios herdados do pai e desbancar o rival Olivi. Além de vencer o pai e Olivi na própria atividade profissional de ambos, Zeno proclama a sua vitória sobre o doutor $\mathrm{S}$. na sua área de atuação de dois modos. $\mathrm{O}$ primeiro deles é a opinião de que se curou sozinho ao assumir com êxito os negócios paternos e, portanto, não precisa mais do tratamento com o psicanalista. O segundo modo se concretiza por meio da própria escrita da carta ao doutor S., pois é nela que Zeno, que não possui nenhuma formação médica, se propõe a refletir sobre as noções de saúde e doença, fundamentais para qualquer terapeuta, com o objetivo declarado de edificar o psicanalista (2004, p. 1081).

Às repetições cujo fim verificamos com base no que Zeno escreve ao doutor S., devemos acrescentar as demais repetições da rivalidade edipiana que enumeramos na segunda seção do segundo capítulo do presente trabalho, pois simplesmente não há registro de que elas ainda ocorram; é o caso, por exemplo, do vício de fumar e das competições sexual e monetária.

Complementarmente ao fim das repetições edipianas, também podemos verificar por meio da carta para o doutor S. que acaba a temporalidade da nota única, na qual o tédio se impõe devido à interrupção das principais repetições. $O$ trecho fundamental para a presente análise é o da declaração de Zeno de que, apesar de estar ocupado o dia inteiro com o comércio, quer dizer ao psicanalista o que lhe cabe (2004, p. 1081-1082). De fato, apesar do encerramento das recorrências edipianas, Zeno não está entediado e, portanto, não efetuou a costumeira passagem da temporalidade repetitiva para a da nota única; longe de tal disposição, está dedicado ao trabalho, o que só fizera antes com duração relevante, ainda que geralmente com pouco empenho, ao cuidar da contabilidade da empresa de Guido, ou seja, em nome da rivalidade edipiana. 
Além disso, notemos que há uma ruptura da relação entre a escrita de Zeno e a temporalidade da nota única, que vigorava desde o início do diário, como propomos na primeira seção do presente capítulo, pois, longe de estar numa situação de ociosidade, ele se põe a escrever a carta apesar de ter pouco tempo livre.

Uma vez que analisamos o fim das repetições da rivalidade edipiana, abordemos em que sentido elas e o recalcado de Zeno permanecem, e o que isso acarreta para a segunda cura. Comecemos constatando a permanência do recalcamento: tal como na primeira cura, Zeno não nos dá nenhum indício de que se tornou consciente das relações edipianas com os pais e das suas repetições. Logo, a segunda cura também é parcial.

A falta de reconhecimento do recalcado e das suas repetições após o sucesso no comércio acarreta duas consequências principais para Zeno. A primeira delas é a de que concebe equivocadamente os efeitos da sua vitória comercial. Assim como não percebeu a transformação da sua sexualidade durante a primeira cura, tampouco percebe a mudança provocada pelo sucesso no comércio no seu comportamento como rival ou reconhece que derrotou o pai com essa demonstração da sua capacidade. Para Zeno, a cura se reduz à nova concepção de saúde e doença que ele próprio elabora, pela qual apenas mudaria de opinião sobre o que antes considerava moléstias para as quais era prioritário e imprescindível procurar tratamentos, passando a conviver normalmente com elas sem mais dedicar a sua vida a tentar curá-las. Com essa interpretação da transformação final pela qual passa, é perfeitamente aceitável que Zeno use palavras como convicção e persuasão ao tratar de saúde e cura (2004, p. 1082).

A segunda consequência da falta de reconhecimento do recalcado e das suas repetições é a permanência da incapacidade de entender o próprio passado. Ela é abordada no seguinte trecho da carta escrita ao psicanalista: "Il dottore, quando avrà ricevuta quest'ultima parte del mio manoscritto, dovrebbe restituirmelo tutto. Lo rifarei con chiarezza vera perché come potevo intendere la mia vita quando non ne conoscevo quest'ultimo periodo? Forse io vissi tanti anni solo per prepararmi ad esso!"99 (2004, p. 1083). Sem que Zeno ao menos reconheça as repetições que constituem a sua subjetividade, não consideramos plausível que seja capaz de entender o próprio passado, inclusive a função das diversas doenças das quais tentou se curar ao longo da vida, e,

\footnotetext{
${ }^{99} \mathrm{O}$ doutor, quando receber esta parte de meu manuscrito, certamente mo devolverá. É preciso refazê-lo para maior clareza por que como poderia compreender a minha vida quando ainda não lhe conhecia este último período? Talvez eu tivesse vivido todos estes anos apenas a fim de me preparar para isto (2006, p. 420)!
} 
portanto, concluímos que a sua tentativa de refazer o relato sobre a própria vida está condenada ao fracasso. Propomos que, para Zeno, se trata apenas de rejeitar novamente a investida final do doutor S., seja com mais uma tentativa de recuperar o manuscrito autobiográfico, seja com a desqualificação da versão original por haver sido escrita quando o autoconhecimento de Zeno ainda era insuficiente.

O recalcado não só permaneceu, como ainda gera repetições. Retomemos, sob esse ponto de vista, as ameaças enumeradas nos parágrafos finais da última seção a fim de verificar em que sentido ainda existiriam repetições do recalcado de Zeno. Quanto às duas primeiras ameças, a degradação ambiental e a superpopulação (2004, p. 1084), elas se inserem na série de recorrências que traduzem a rivalidade em termos espaciais ou respiratórios ao abordar tais perigos quase exclusivamente pelo aspecto da competição pelo espaço: o homem ocupou o lugar de outros organismos, e a insistência em pensar na provável falta de espaço resulta até mesmo numa sensação de sufocamento!

Para retomarmos a ameaça dos artefatos de destruição em massa (2004, p. 1085), precisamos recorrer à análise que fizemos da função da intensidade do som na segunda e terceira seções do diário. Diante dessa recente e relevante função, ganha especial importância um detalhe bastante peculiar do modo como Zeno concebe uma explosão capaz de destruir toda a vida do planeta. De fato, essa explosão, o elemento mais agressivo do romance, deveria provocar o maior estrondo produzido na Terra em milênios, em relação ao qual os gritos dos militares relatados na seção anterior - um dos principais meios pelos quais o protagonista é explicitamente objeto da hostilidade liberada pela guerra iminente - e o zurro referido na segunda seção seriam completamente desprezíveis, mas Zeno imagina que a bomba seria colocada no centro do planeta para maximizar o seu efeito, de modo que a explosão não seria sequer ouvida! Assim, Zeno concebe esse ato radicalmente violento de modo a excluir não só qualquer declaração de agressão, como geralmente ocorre nas manifestações comuns da hostilidade velada, mas também o som da própria agressão, como se a impedisse de declarar a si própria. Além disso, a destruição de toda a vida do planeta é um ápice de outra repetição edipiana, a do desejo de morte.

Uma vez que constatamos que Zeno ainda é acometido por repetições do recalcado, podemos nos perguntar o quanto ele efetivamente mudou com a vitória no comércio, inclusive o quão sadio realmente está. Dedicaremos o final desta seção a dar uma resposta plausível a esse questionamento com base nos nossos comentários sobre a concepção sobre a saúde e a doença que é apresentada pelo próprio texto, segundo a 
qual a distinção entre essas condições vitais é uma questão de grau e o que importa é manter-se afastado das enfermidades que provocam restrições severas.

Antes das curas, a situação de Zeno era muito restritiva: em grande parte das vezes, ele só tomava a iniciativa de fazer algo na medida em que conseguisse repetir comportamentos edipianos e, quando nada permitisse essa repetição, era dominado por um tédio que o prostrava. O controle sobre a própria vida também era muito restrito, pois tais repetições geralmente eram realizadas por motivos diferentes dos que Zeno lhes atribuia.

Verifiquemos como ficam as restrições mencionadas após as duas curas. Não identificamos mais nenhuma repetição exclusiva da relação com a mãe desde o abandono da terapia. No que se refere à repetição da rivalidade paterna, só temos a última seção do capítulo final para considerar o quanto ela ainda restringe a vida de Zeno. A situação apresentada é decisivamente melhor, pois ele não está mais dominado pelo tédio, mencionado nas seções anteriores do último capítulo, e as repetições que ainda acontecem, tais como as que encontramos na sensação de sufocamento e na explosão final, não são mais determinantes para a condução da ação e do pensamento de Zeno na medida em que tudo indica que a ausência delas não provocaria alterações relevantes no modo como ele age e pensa. Em suma, elas não possuem mais importância prática.

Exemplifiquemos a mudança na influência da repetição com o caso da declaração da rivalidade: Zeno decide enviar o que já havia escrito ao psicanalista, de modo que lhe revela as hostilidades que escrevera a seu respeito, escreve-lhe para proclamar a vitória sobre ele e, em vez de negar a guerra - como fizera ao estar na presença dela -, expõe claramente, nos parágrafos finais, a hostilidade dos homens mesmo sem guerra. Diante dessa portentosa exposição de manifestações de rivalidade, conceber a concretização da ameça de destruição do planeta propiciada pela criação de um explosivo incomparável como uma agressão inaudível que só se revela no momento final é apenas um deslize sem importância prática (a própria argumentação de Zeno não sofreria nenhuma alteração relevante se ele imaginasse que a explosão seria anunciada e acompanhada pelo maior estrondo de todos os tempos), além de o deslize ser neutralizado pelo próprio contexto no qual se insere, a saber, que Zeno esteja justamente alertando para a possibilidade de tal evento de destruição do planeta pelo homem.

Por fim, considerando o arcabouço psicanalítico que propomos que o romance mobiliza, ressaltemos que Freud também fazia uma distinção meramente quantitativa 
entre as pessoas psiquicamente sadias e os neuróticos, na qual a importância prática desempenha uma função crucial:

[...] se alguém submete a um exame mais atento sua vida desperta, descobre

[...] que essa vida pretensamente sadia está marcada aqui e ali por grande número de sintomas banais e destituídos de importância prática.

A distinção entre saúde nervosa e neurose reduz-se, por conseguinte, a uma questão prática e é decidida pelo resultado, isto é, a pessoa ter ou não ter um nível suficiente de capacidade para aproveitar a vida e ser eficiente. Tal distinção [...] é de natureza quantitativa, não qualitativa. (1976a, p. 532-533)

Logo, a nossa conclusão é de que Zeno é efetivamente transformado pelas duas curas, ainda que elas sejam parciais por não tornarem conscientes os conteúdos recalcados, na medida em que as repetições do recalcado passam a ser desprovidas de importância prática.

Antes de encerrarmos a presente seção, notemos que, assim como a temporalidade linear se torna residual devido à primeira cura parcial, as temporalidades de repetição e da nota única, que são intrinsecamente vinculadas, encontram o mesmo destino ao serem reduzidas à irrelevância prática pela segunda cura. Essa observação nos impõe o questionamento sobre a temporalidade resultante após as duas curas parciais. Consideramos que uma resposta satisfatória a essa questão exige uma abordagem geral do romance, a qual também fornecerá elementos que reforçam a nossa conclusão sobre a transformação efetiva de Zeno. Encerraremos a nossa análise do romance a partir da repetição do recalcado na próxima seção, na qual justamente exploraremos as transformações que são delineadas no âmbito global desse texto.

\subsection{As transformações da repetição do recalcado e das articulações temporais no âmbito global do romance: da autobiografia às previsões evolutivas sobre o destino da humanidade}

Dedicamos esta seção a investigar tanto as transformações das articulações temporais que são delineadas no âmbito global do romance à medida que as repetições do recalcado de Zeno são modificadas pelas duas curas parciais quanto a temporalidade resultante da combinação dessas transformações.

Faremos a investigação proposta retomando resultados da nossa análise sobre a autobiografia de Zeno, expondo mudanças transcorridas ao longo do último capítulo do 
romance, tanto as que invalidam esses resultados quanto as que introduzem os aspectos cruciais da experiência temporal que vigora no fim do romance, e elaborando propriamente uma apresentação dessa temporalidade.

Comecemos retomando o que já exploramos em profundidade sobre a autobiografia de Zeno nos dois capítulos anteriores. Como protagonista e narrador, Zeno opera segundo diversas repetições do recalcado, que podem se confrontar ou se reforçar em vários níveis de complexidade, inclusive combinando as repetições de ambos na narrativa. Além disso, quando é impedido de manter as principais recorrências edipianas segundo as quais estava operando, Zeno se sente prostrado pelo tédio da temporalidade da nota única.

Devido às repetições do recalcado não serem normalmente reconhecidas por Zeno sequer como recorrências, o modo pelo qual concebe a própria experiência em termos temporais é bem diferente da repetição que a constitui; mais precisamente, exploramos como Zeno geralmente a concebe segundo as temporalidades linear e de onda.

Além das quatro temporalidades principais que compõem a autobiografia de Zeno, retomemos também as análises sobre uma importante mudança que ocorre na articulação entre elas, com a qual terminamos o capítulo anterior, e sobre o preâmbulo como base para destacar uma dissociação dupla e acumulativa entre os dois principais elementos do tempo da narração, a terapia e a autobiografia, os quais estão inicialmente ligados completamente, já que Zeno só se torna o narrador da própria vida por uma prescrição do doutor S. que tem por objetivo prepará-lo para a terapia.

Quanto ao preâmbulo, fornece a base para a primeira dissociação entre a terapia e a autobiografia ao apresentar a recomendação do psicanalista para valorizar o presente do narrador a fim de recuperar o passado, pois Zeno implicitamente rejeita essa recomendação ao aceitar a de iniciar a escrita autobiográfica com a análise histórica da sua propensão ao fumo. No tocante à mudança que analisamos no fim do capítulo anterior, está intrinsecamente vinculada à segunda dissociação. Para começar, recordemos que expusemos como a predominância da abordagem temática e o fato de o tema do fumo inibir divergências repetitivas entre o protagonista e o narrador promovem a identificação das repetições de Zeno, o que efetivamente serve de preparação para o tratamento psicanalítico. É em oposição a esse contexto que podemos reconhecer a segunda dissociação no afastamento definitivo da escrita do narrador em relação às recomendações do doutor S. a partir do próximo capítulo da autobiografia: 
em termos de conteúdo, pela simples ausência de uma orientação terapêutica na escolha feita pelo próprio Zeno de escrever sobre a morte do pai; em termos formais, pelo predomínio da cronologia em detrimento da abordagem temática, a qual fica restrita a trechos curtos e à própria divisão em capítulos, que, no entanto, são em grande medida recortes sucessivos da vida do protagonista.

Em suma, propomos que as duas dissociações entre a terapia e a autobiografia são os momentos cruciais de um processo pelo qual a escrita de Zeno se afasta da função original que lhe conferiu o doutor S., a de preparação para o tratamento psicanalítico, para ser apropriada por Zeno como instrumento para que ele, desta vez como narrador, produza repetições edipianas, tanto em convergência quanto em divergência com as do personagem, sem que elas se tornem mais reconhecíveis do que eram as do protagonista.

O último resultado que retomaremos do nosso estudo sobre a autobiografia de Zeno está em estreita relação com a função que ela possui de propiciar repetições do recalcado ao narrador. Trata-se da temporalidade da nota única na qual se encontra Zeno no tempo da narração, conforme argumentamos no início da quarta seção do capítulo anterior. Ora, ao se constituir como narrador, Zeno reage ao tédio dessa condição temporal justamente na medida em que a escrita autobiográfica lhe propicia a produção de repetições edipianas.

Uma vez que retomamos os resultados da nossa análise sobre a autobiografia de Zeno que nos importam para a presente investigação, voltemos a abordar o último capítulo do romance, principalmente a carta, para destacar as mudanças que se tornam especialmente importantes ao serem consideradas no âmbito global do romance devido à alteração desses resultados, começando pelas modificações diretas dos mesmos. Quanto à relação entre a escrita e a temporalidade da nota única, comentamos na seção anterior que ela permanece no diário, mas desaparece na carta para o doutor S., pois Zeno a escreve apesar de estar muito ocupado.

A escrita e a terapia se tornam cada vez mais dissociadas. No caso do diário e da carta, Zeno escreve por iniciativa própria em vez de seguir uma recomendação médica; mais precisamente, consideramos que se trata de reagir às investidas do doutor S. para retomar o tratamento. No diário, a oposição à primeira dessas investidas ainda ocorre como repetição da hostilidade velada de Zeno na medida em que lhe serve para confirmar para si mesmo que a terapia não melhorou a sua saúde e, portanto, refutar o argumento inicialmente usado pelo psicanalista para que o seu paciente retorne ao 
tratamento. Finalmente, o objetivo principal da carta é hostilizar declaradamente o doutor S. de diversas maneiras, como expusemos na seção anterior, e, portanto, quando Zeno a escreve não produz mais uma repetição do recalcado, ao contrário da autobiografia e do diário; logo, a carta ainda trata da terapia, mas apenas notifica o seu abandono definitivo para o doutor S. a fim de hostilizá-lo e, portanto, já não é escrita por causa do tratamento, de modo que o processo de dissociação que acompanhamos desde o início da autobiografia está completo.

A propósito do fim das repetições do recalcado, investigamos como o último capítulo promove duas etapas desse término, que desagregam as quatro temporalidades principais e a articulação estabelecida entre elas na autobiografia. A primeira etapa é o fim das repetições exclusivas do desejo pela mãe, cujos primeiros efeitos percebemos assim que Zeno abandona a terapia: após uma transição na primeira seção do diário, cuja história antecede esse abandono, a temporalidade linear se torna pouco relevante, seja porque o relato de cada dia se reduz basicamente ao registro dos seus acontecimentos, os quais não são elaborados segundo uma unificação que pretenda superar a sua mera sucessão, seja por causa da própria forma de um diário que resulta numa fragmentação de dias esparsos que não insiste em encadear os dias relatados numa articulação global. Apesar dessas relevantes mudanças, as temporalidades restantes - a de onda, a da nota única e as repetições envolvendo a rivalidade edipiana - continuam a se articular entre elas como faziam antes do diário de modo a constituir a configuração temporal que é predominante tanto para o protagonista após o abandono da terapia quanto para o narrador do diário.

A segunda etapa do fim das repetições do recalcado é o término da relevância prática dessas recorrências após a vitória de Zeno no comércio. As demais temporalidades que permaneceram na primeira etapa também deixam de ser importantes. No tocante à da nota única, Zeno não está mais entregue ao tédio apesar do término das repetições. Quanto à de onda, não pode mais ser causada pela falta de reconhecimento das recorrências edipianas, como ocorreu na autobiografia e no diário, nem nos parece ser razoável que o acaso ainda seja relevante, seja no caso da atividade comercial do protagonista, sobre a qual só sabemos que está baseada nas condições excepcionais que a guerra gerou, seja no caso das reflexões do autor da carta sobre as noções de saúde e doença e sobre as ameaças à existência humana. Logo, consideramos que a experiência temporal de Zeno não pode mais ser analisada segundo as quatro temporalidades que a constituiam até a cura pelo comércio. 
Uma vez que concluímos que as temporalidades que consideramos serem cruciais para a experiência temporal de Zeno na autobiografia e nas três primeiras seções do diário deixam de ser relevantes após a vitória do protagonista no comércio, recorramos a indícios fornecidos por duas outras mudanças que ocorrem no último capítulo a fim de elaborarmos uma resposta sobre a experiência temporal que se instala no fim do romance.

Comecemos analisando o percurso do texto com base nas posições temporais da narração em relação à história que foram propostas por Genette, as quais apresentamos no primeiro capítulo: ulterior, intercalada, simultânea e anterior. Na autobiografia, a posição temporal da narração é ulterior, e a história trata do passado remoto do protagonista. No diário, ela é intercalada na maior parte do texto, como é comum a esse modo de produção escrita, e simultânea no restante, pois o narrador também comenta o próprio ato de escrever e a sua doença de um modo que extrapola a trama relatada em cada seção; além disso, em vez do passado remoto de Zeno, trata-se do seu passado recente e do seu presente. Finalmente, a carta prossegue com as posições intercalada e simultânea, mas com duas diferenças que são relevantes para as mudanças que estamos analisando: desta vez, a segunda é maior que a primeira e não é mais totalmente narrativa, pois já não se trata apenas da doença de um personagem ou do narrador, mas também de uma reflexão sobre a doença em geral. As ameaças à existência humana no término da carta também são uma reflexão de Zeno e completam o percurso por meio da posição anterior. Apenas nesse trecho derradeiro há uma proliferação de verbos no futuro, e Zeno se dedica aos tempos que virão. Em suma, destacamos que há uma gradação temporal nos conteúdos aos quais a escrita de Zeno se dedica de um modo geral: são muito antigos na autobiografia, são recentes ou do presente da narração no diário e na maior parte da carta e só estão orientados para o futuro nos parágrafos finais da carta.

A segunda mudança que ocorre no último capítulo e à qual recorremos para compreender qual seria a experiência temporal que nos oferece o fim do romance é a da abertura efetiva para o ambiente em detrimento da fixação em si mesmo. Comecemos expondo um quadro geral desse aspecto do romance, o qual já exploramos de diferentes maneiras ao longo do presente trabalho, para depois avaliar o tratamento final que recebe após a segunda cura parcial. De fato, a repetição do recalcado impede que Zeno acompanhe efetivamente as mudanças ao seu redor que já não sejam compatíveis com essas repetições, o que produz uma defasagem temporal entre Zeno, preso ao próprio 
passado, e o presente do ambiente modificado. Ao apresentarmos essa defasagem na última seção do segundo capítulo, exemplificamos tal fenômeno com a reação do protagonista aos noivados de Augusta e Ada com ele e Guido: em vez de assumir o novo presente dos noivados e depois dos casamentos, Zeno continua a se dedicar ao desejo por Ada, que já o recusou e escolheu outro homem para casar. Na seção anterior, tratamos daquela que talvez seja a mais extrema de tais defasagens, a da negação da guerra e da agressividade declarada que lhe é intrínseca, de modo que nem mesmo as mudanças históricas conseguem superar o descompasso causado pela repetição do recalcado. Notemos ainda que a guerra é a primeira aparição relevante no romance do tempo histórico que é contemporâneo ao tempo vivido pelo protagonista ou pelo narrador; antes disso, havia menções pontuais a eventos históricos do passado.

Em face do quadro geral que apresentamos, é grande o contraste que se instaura a partir da segunda seção do último capítulo e culmina na carta ao doutor S., uma vez que não só o próprio ambiente no qual Zeno vive sofre mudanças, mas também ele finalmente está suscetível a ser efetivamente transformado por elas. Quanto ao primeiro fator de contraste, notemos que a história do romance transcorre no ambiente burguês de Trieste até a segunda seção e depois não retorna mais a esse ponto de partida, pois o protagonista viaja para uma cidade pequena, na qual passa momentos isolado na natureza e interage com camponeses, e o próprio ambiente burguês é tranformado pela eclosão da guerra, a qual modifica até mesmo o funcionamento do comércio.

No tocante ao segundo fator de contraste que mencionamos, exploramos na seção anterior como as transformações efetivas de Zeno na segunda e na quarta seções do capítulo final estão associadas à viagem para o campo e à guerra. Nesse sentido, a última transformação é especialmente importante, pois só ocorre devido à mudança radical no comércio que é causada pelo conflito bélico.

Sintetizando as nossas considerações sobre as duas mudanças que abordamos do último capítulo, propomos que o âmbito global do romance oferece a passagem da fixação de Zeno no próprio passado da autobiografia e da primeira seção do diário para a atenção privilegiada que ele concede ao presente e, após a segunda cura parcial, às suas consequências para o futuro, sendo que essas duas dimensões temporais são consideradas não só no âmbito do indivíduo, mas também do seu ambiente, numa gradação que começa pela inclusão do campo, avança para o nível das nações ao abordar uma guerra e atinge o planeta inteiro nos parágrafos finais da carta. 
Assim, elaboraremos a nossa resposta sobre a experiência temporal que se instala após a segunda cura parcial analisando a carta que encerra o romance como o ápice da gradativa transformação iniciada na segunda seção do diário que supera o passado de orientação indivídual em favor do presente e do futuro do indivíduo no seu ambiente. Façamos a análise proposta tanto do ponto de vista da diegese quanto da perspectiva da escrita da carta.

Quanto à diegese após a segunda cura parcial, ela se restringe à atividade comercial que ocupa os dias de Zeno, a qual se define justamente pelo abandono do passado do comércio, no qual o protagonista era totalmente incapacitado, e pelo inédito sucesso efetivo de Zeno nessa atividade, o qual justamente está vinculado ao ambiente comercial que foi radicalmente transformado pela guerra, pois o protagonista compreende que a miséria provocada pelo conflito faria com que as pessoas aceitassem o incenso como substituto da resina (2004, p. 1083). Em suma, ao ter o comércio em tempo de guerra como ocupação principal, a ação de Zeno está orientada para o presente e para ações coletivas de abrangência nacional.

No tocante à escrita da carta, abordemos tanto o seu motivo quanto o seu conteúdo e a adoção de uma abordagem narrativa. Comecemos retomando como os aspectos enumerados são tratados na escrita anterior à carta. Zeno escreve a autobiografia como preparação para o seu tratamento psicanalítico e o diário para debelar a investida do doutor S. para que retome a terapia comprovando que esta não melhorou a sua saúde, de modo que o motivo final da escrita está limitado ao âmbito individual. Essa limitação aparece novamente e, neste caso, junto à orientação privilegiada para o passado no fato de Zeno se dedicar à narração das próprias vivências, seja na autobiografia recomendada pelo doutor S., seja no diário que Zeno, por si mesmo, decide escrever e no qual não abandona a narrativa da própria história.

Uma vez que expusemos como o passado de orientação indivídual domina a escrita da autobiografia e do diário, investiguemos como ele é amplamente superado pela escrita da carta. Quanto à motivação de Zeno, avaliamos que a carta, ao ser escrita para ser uma franca hostilidade contra o doutor S., supera o âmbito individual na medida em que o objetivo principal é agir sobre outra pessoa. No tocante à abordagem adotada na escrita e ao seu conteúdo, observamos uma dupla ruptura. A primeira delas é a perda da ampla primazia que a narração, um modo de escrita geralmente dedicado ao que é anterior à escrita, tivera na escrita prévia de Zeno em favor de uma abordagem reflexiva, cujo objeto principal geralmente pertence ao presente de quem escreve. A 
segunda ruptura é a substituição do conteúdo autobiográfico pela exposição da nova concepção de Zeno sobre a saúde e a doença e das ameaças que elenca para a existência da humanidade e da vida em geral, o que não só confirma a mudança de primazia do passado para o presente que a troca da narração pela reflexão já preparava, mas também abandona definitivamente a perspectiva marcadamente individual para tratar de questões cujo alcance está no extremo oposto ao do indivíduo, pois abarcam a totalidade dos seres vivos. Observemos também que o conteúdo final da escrita reflexiva da carta abarca também o futuro ao tratar das ameaças de destruição da vida cuja a possibilidade já pode ser identificada no presente, culminando na hipótese da invenção do explosivo incomparável, que imediatamente nos recorda da criação da bomba atômica cerca de duas décadas depois da publicação do romance.

A fim de reforçar a superação que a carta de Zeno realiza do passado de orientação indivídual, destaquemos mais um elemento do seu conteúdo, a teoria da evolução. Ela surge na argumentação sobre a humanidade haver trocado a seleção natural pela seleção segundo a posse dos artefatos (2004, p. 1084-1085). Nesse trecho, há uma declaração de que seria necessário algo diferente da psicanálise, de modo que se cria uma contraposição entre as teorias criada por Freud e Darwin. Abordemos a superação em análise recorrendo a dois aspectos dessa contraposição. Para começar, ponderemos que, assim como a mudança da narração para a reflexão contribui para a transição da predominância do passado para o presente, a mudança de referência teórica contribui para a passagem do âmbito do indivíduo, no qual se baseia a investigação psicanalítica, para o da vida em geral, no qual se realiza a evolução das espécies biológicas.

Além da contribuição intrínseca para estabelecer o âmbito da vida em geral, propomos que a teoria da evolução também é usada de modo a contribuir para a superação do passado como temporalidade privilegiada anteriormente pelas repetições do recalcado de Zeno e, portanto, pelo principal uso que o romance faz da psicanálise. Com efeito, consideramos que Zeno, amparado na sua nova concepção sobre a saúde e a doença, usa a evolução para identificar o que está colocando a vida sob alguma grave ameaça, ou seja, para tratar das consequências desastrosas da ação atual. Ao mesmo tempo, para compreender como a seleção pela posse de artefatos pode ser desastrosa, Zeno compara a história dos artefatos com a da evolução de algumas espécies segundo a seleção natural, de modo que, numa grande abertura temporal, recorre a um passado de alcance milenar para subordiná-lo à preservação da vida no âmbito do presente e do 
futuro que já estaria em preparação.

Em suma, a nossa resposta sobre a experiência temporal que se instala após o fim das repetições do recalcado pelas duas curas parciais é que Zeno supera a sujeição da sua ação e da sua escrita, na forma de narração, ao passado de âmbito individual para tanto agir, por meio da sua ocupação comercial, orientado para o presente e em interação efetiva com os agentes econômicos da sua região quanto escrever dedicado a reflexões sobre o presente e o futuro que está em preparação que abrangem não só a humanidade, mas também o planeta inteiro.

Por fim, entendemos que um último esclarecimento se faz necessário para evitar que a resposta que apresentamos seja compreendida como uma afirmação de que o romance proporia que as curas parciais de Zeno resultam na sua plena integração à sociedade burguesa na qual se encontra. Não se trata disso, pois, por um lado, comentamos que ele só prospera no comércio por não praticá-lo como um comerciante convencional e, por outro lado, raramente encontramos alguma propensão para a reflexão que não seja destinada ao mero exercício das ocupações de cada indivíduo nos demais personagens burgueses.

Não só avaliamos que as curas parciais não tornam Zeno um burguês, mas também propomos que a reflexão sobre as ameaças para a existência da humanidade que as curas propiciam ao permitir que ele supere o passado de orientação individual ao qual ficava limitado pelas repetições do recalcado pode ser entendida como uma crítica à sociedade burguesa. Como apoio para a nossa proposta de tal crítica, recorremos à análise que o narrador faz da saúde da esposa no início do sexto capítulo. Conforme comentamos na quarta seção do capítulo anterior, Zeno declara na referida análise que a saúde burguesa é incapaz de analisar a si própria. Ora, essa declaração que Zeno faz a respeito da saúde de Augusta pode ser aplicada para a sociedade burguesa em seu conjunto com a reflexão sobre as ameaças para a existência humana na medida em que quem se dedica a identificar as tendências dessa sociedade para a própria destruição é alguém que permanece irredutível a ela até o fim do romance. 


\section{Capítulo 5 \\ A REPETIÇÃO DO RECALCADO E A ELABORAÇÃO DAS ARTICULAÇÕES TEMPORAIS NAS “CONTINUAÇÕES”}

No presente capítulo nos dedicaremos às "continuações", das quais trataremos das três transformações na compulsão à repetição do recalcado que Zeno sofre desde o fim da Primeira Guerra Mundial até retornar à escrita autobiográfica e investigaremos em que medida elas determinam as articulações entre os tempos da história, da narrativa e da narração.

Tal como no caso do terceiro capítulo, a base da relação entre a noção psicanalítica da repetição do recalcado com a criação literária no presente capítulo são o tempo literário, no qual estão imbricados os aspectos temporais da história, da narrativa e da narração, e o narrador, na medida em que a sua elaboração está profundamente vinculada aos tempos da narrativa e da narração, os quais são de grande importância para as "continuações".

A fim de cumprirmos a tarefa que estabelecemos para o presente capítulo, trataremos da recaída do protagonista na compulsão à repetição do recalcado, que é a primeira das três transformações da compulsão repetitiva de Zeno nas "continuações", com base na apresentação que é feita dessa recaída no texto Un contratto; investigaremos os principais aspectos da articulação entre os tempos da história e da narrativa em cada uma das "continuações" e apresentaremos a segunda transformação da compulsão, a inibição das repetições edipianas do protagonista; estudaremos a constituição de Zeno como escritor autobiográfico e a sua relação com a última das três transformações, a retomada das repetições que estão inibidas no protagonista; examinaremos como Zeno efetivamente realiza essa retomada por meio da atividade narrativa; e investigaremos o limite de tal retomada pela escrita e as suas consequências principais para as articulações temporais das "continuações".

Antes de efetivamente nos dedicarmos à tarefa do presente capítulo, retomemos os dois critérios que adotamos na nossa abordagem dos cinco textos das "continuações" devido à condição inacabada na qual Svevo os deixou, conforme expusemos na introdução deste trabalho. O primeiro deles é o de que geralmente consideraremos cada um dos textos da maneira como ficaram, ou seja, evitaremos imaginar as modificações que Svevo faria num processo de revisão ou com o objetivo 
de reuni-los num romance. O segundo critério em questão é o de nos limitarmos a uma abordagem comparativa ao considerar as relações entre os cinco textos, pois não sabemos sequer a ordem na qual ficariam ao serem reunidos ou se Svevo pretendia escrever outros, e desconsideraremos o que geralmente seria revisado ao reuni-los, tais como repetições de relatos ou reflexões do narrador e pequenos materiais narrativos que são diversamente aproveitados. Logo, não faremos para as "continuações" uma seção como aquela que termina o capítulo anterior deste trabalho, dado que ela estava baseada justamente na nossa proposta de identificar relações progressivas dentro do romance que ultrapassam a sua divisão em capítulos.

\subsection{A organização temporal específica da diegese do texto Un contratto: a gradual recaída na repetição da rivalidade edipiana e na temporalidade da nota única}

O texto Un contratto possui uma característica especial, a de continuar a história com a qual é encerrado o romance, pois conta como Zeno abandona a condução dos negócios herdados do pai, a qual é assumida pelo filho de Olivi. O texto Le confessioni del vegliardo apresenta uma versão resumida (2004, p. 1118-1121) dos principais acontecimentos desse abandono, mas trabalharemos com a versão do texto Un contratto por ser mais completa e ser continuada pela história do contrato que o filho de Olivi lhe impõe.

Dedicamos a presente seção a investigar a recaída do protagonista na compulsão à repetição, a primeira das três transformações de Zeno em relação a essa patologia compulsiva nas "continuações", na medida em que consideramos que ele volta a apresentar as repetições edipianas de rivalidade contra o pai e a temporalidade da nota única, as quais haviam terminado devido à segunda cura parcial: analisaremos como a história do texto Un contratto expõe a situação inicial de Zeno e as três etapas da sua recaída e abordaremos a história dos demais textos das "continuações" para tratar das limitações desse retrocesso e para verificar em que medida as repetições do recalcado que voltaram na recaída continuam ocorrendo e as demais não voltam a ocorrer.

Comecemos examinando a situação inicial do protagonista no texto $U n$ contratto para depois abordarmos a sua recaída. A história começa com o fim da guerra 
e a carta para Olivi (2004, p. 1089-1090). O protagonista tenta manter a situação proporcionada pela guerra mesmo após ela haver terminado, dado que continua a conduzir os negócios como fazia durante o conflito e escreve a carta para Olivi a fim de evitar que, com o retorno da paz, o antigo administrador reassuma o comando da empresa. No caso da missiva, ela também equivale àquela que Zeno envia ao doutor $\mathrm{S}$. no fim do romance na medida em que ambas são declarações de vitória sobre os rivais: naquela dedicada ao psicanalista, o informa que foi curado pelo comércio e não precisa mais da terapia; naquela escrita para Olivi, relata o próprio sucesso nos negócios e propõe que ele e o filho voltem a trabalhar na empresa, mas sob as ordens de Zeno, que continuaria na posição de comando que assumiu durante o conflito bélico.

Em suma, consideramos que o protagonista começa tal como estava após a segunda cura parcial, ocorrida com a vitória no comércio, conforme analisamos no capítulo anterior; porém, essa situação inicial não é estável. De fato, ela é rapidamente superada pelo que propomos ser uma recaída de Zeno ao seu estado entre as duas curas parciais, cuja base está justamente no fim da guerra: à sucessão formada pela guerra, ruptura do comércio convencional e vitória comercial de Zeno que a seção final do último capítulo oferece, o texto Un contratto responde com a sucessão oposta que é formada pela paz, volta ao comércio convencional e derrota do protagonista por meio de um negócio desastroso (2004, p. 1090-1091), pelo qual perde quase tudo que lucrou durante o confronto.

Propomos que Zeno passa por uma recaída quase completa ao seu estado anterior à segunda cura parcial e que ela ocorre em três etapas, a primeira das quais inicia justamente com o negócio desastroso. Depois desse evento, Zeno não está mais propriamente ocupado com o comércio, como estivera desde que fez os negócios com o incenso, ainda durante a guerra. Ele se restringe a ser apenas o dono da empresa, pois quem efetivamente conduz os negócios passa a ser o filho de Olivi (2004, p. 10921093). Apesar disso, ainda não parece haver retomada das repetições edipianas; pelo contrário, parece haver uma refutação implícita de tal retorno, uma vez que o relato dessa etapa se concentra sobre os duelos verbais entre o protagonista e o filho de Olivi sobre questões ligadas à guerra (2004, p. 1091-1094), dos quais está ausente a hostilidade velada que, conforme analisamos na terceira seção do segundo capítulo, caracteriza a rivalidade edipiana de Zeno, pois o protagonista ganha os duelos de franca hostilidade e não age no sentido de compensar a clara vitória sobre o oponente.

De passagem, observemos que elencamos no segundo capítulo duas repetições 
do recalcado que ocorrem até a primeira etapa da recaída e esclareçamos que ambas não tem importância prática, tais como aquelas que ocorrem após a cura pelo comércio, conforme comentamos na terceira seção do capítulo anterior. Exemplifiquemos isso com a reação de Zeno após ganhar o último duelo verbal alçando a voz para o filho de Olivi: o protagonista se aborrece por falar alto e reconsidera favoravelmente o argumento do adversário (2004, p. 1094); entretanto, essa compensação exigida pela hostilidade velada não tem nenhuma consequência prática, pois não ganha nenhum desenvolvimento e fica limitada ao próprio Zeno devido a ele não tentar apaziguar a situação com o filho de Olivi, o qual continua a ser o único derrotado inconteste nos embates verbais com o patrão.

A segunda etapa da recaída de Zeno ocorre com o retorno do tédio e o progressivo afastamento do escritório (2004, p. 1094-1095). Já examinamos na última seção do segundo capítulo que se trata da temporalidade da nota única devido à incapacidade do protagonista manter a rivalidade edipiana com o filho de Olivi por não descobrir um modo de derrotá-lo. Notemos também que não encontramos menção a um estado tedioso no romance desde a vitória do protagonista no comércio. Assim, consideramos que Zeno retorna à articulação entre a temporalidade da nota única e a repetição do recalcado à qual estava submetido até a segunda cura parcial. De fato, em vez das vitórias nos duelos verbais, a rotina do protagonista no escritório não lhe dá mais oportunidades de vencer o filho de Olivi, se resumindo a tentativas fracassadas de dar conselhos sobre os negócios e de encontrar alguma falha do rival na condução da empresa, sendo que estas já constituem ocorrências frustradas da competição comercial que caracteriza a rivalidade edipiana de Zeno, conforme examinamos na segunda seção do segundo capítulo.

Assim, propomos que a perda de qualquer afluência prática sobre o filho de Olivi e as atividades da empresa finalmente invalida a vitória que o protagonista obtivera no comércio durante a guerra, de modo que ele retorna ao estado prévio à segunda cura parcial, o das repetições da rivalidade edipiana. É a favor dessa proposta que argumentaremos no restante da presente seção, a começar pela etapa em análise da recaída do protagonista: ele volta à rivalidade edipiana ao insistir em encontrar uma falha na condução dos negócios pelo filho de Olivi e, ao fracassar em todas as tentativas de vencer o rival dessa maneira, se afasta por conta própria do escritório e retorna ao tédio da temporalidade da nota única.

A terceira e última etapa da recaída de Zeno é a do novo contrato proposto pelo 
filho de Olivi, inicialmente por intermédio de Valentino (2004, p. 1095). A disputa em torno do contrato é a oportunidade para Zeno retomar a rivalidade edipiana contra quem o substituiu no controle da empresa herdada do pai; na verdade, a partir dessa proposta, acompanhamos Zeno entregue ao exercício irrestrito da repetição do recalcado a que estava submetido antes da segunda cura parcial. Quanto ao contrato em si, os elementos cruciais são a competição monetária e o próprio controle da empresa. No tocante ao primeiro deles, após se afastar da direção da empresa na segunda etapa da recaída, o protagonista ao menos continuava a ganhar mais do que o administrador, pois ficava com os lucros e este apenas com um salário. Ora, como já aparece na proposta apresentada por Valentino, o filho de Olivi quer um aumento de salário e ficar com a metade dos lucros, de modo que ganharia mais com a empresa do que o próprio dono. A única negociação efetiva que Zeno faz sobre as cláusulas contratuais é justamente para que ambos tenham ganhos iguais, conforme já comentamos na segunda seção do segundo capítulo. Mesmo após a assinatura, a competição monetária volta a aparecer quando o protagonista se ofende com a cláusula na qual perde metade do capital para o administrador se quiser fechar a empresa (2004, p. 1114).

$\mathrm{Na}$ ocasião da assinatura do contrato, Zeno finalmente lamenta a perda definitiva da direção da empresa herdada do pai, dado que uma das cláusulas o deixa limitado a dar conselhos que o filho de Olivi pode recusar (2004, p. 1109-1110). Logo, a situação do protagonista em relação à empresa que era do seu pai é uma derrota equivalente àquela que o seu pai lhe impusera ao determinar no testamento que manteria Olivi na condução da empresa sem que Zeno tivesse autoridade sobre ele, pois o contrato assinado transfere a decisão final nos negócios para o filho do administrador imposto pelo pai.

Uma vez que analisamos a rivalidade edipiana que está relacionada intrinsecamente ao contrato e o resultado desastroso de assiná-lo, avaliemos como ela organiza as demais repetições do recalcado do protagonista. Como elas estão, em sua quase totalidade, claramente associadas a um dos rivais edipianos que o texto $U n$ contratto instaura, nos restringiremos a esses casos ao avaliarmos tal organização. Apenas para exemplificar que a rivalidade baseada no contrato também é crucial para outros casos, mencionemos o comentário que fizemos na segunda seção do segundo capítulo sobre o trecho no qual o prejudicado imediato pelo contrato é o filho de Zeno, que não é instaurado como rival edipiano pelo texto em análise: a cláusula que impede Alfio de se tornar sócio da empresa realça a que ponto o protagonista perdeu o controle 
para o filho de Olivi.

Além do filho de Olivi, que já era um rival edipiano na segunda etapa da recaída, os rivais de Zeno que são instaurados pelo texto Un contratto são um advogado (2004, p. 1097-1098) e principalmente Valentino, e se tornam tais porque não o apoiam efetivamente para evitar a derrota inerente à assinatura do contrato. Não analisaremos a relação com o advogado porque é bastante direta e se resume a dois parágrafos. Quanto ao filho de Olivi, já tratamos bastante dele no segundo capítulo e na presente seção; acrescentemos somente que Zeno ainda insiste em pensar em maneiras de prosseguir a luta contra o adversário mesmo após a derrota definitiva, tal como a suposição de que os pais de ambos reprovariam o oponente devido ao contrato assinado (2004, p. 1114).

No tocante ao genro, ele também se torna um rival por causa de Antonia. Já expusemos a participação de Valentino em algumas repetições do recalcado de Zeno no segundo capítulo: a competição sexual por Antonia e a rivalidade velada, seja pensando na própria "bondade" por não ser tão agressivo quanto desejava, seja pela culpa que sente quando o genro morre por uma doença que imaginou ter e que seria a causa de não conseguir evitar a assinatura do contrato. No que se refere especificamente ao contrato, após Valentino se apresentar como encarregado de tratar do novo contrato com Zeno, a principal iniciativa do protagonista para com o genro será justamente se negar a envolvê-lo na negociação do contrato: mencionando explicitamente o esforço para afastá-lo da discussão, vai ao escritório para tratar do assunto diretamente com o filho de Olivi e, quando este conta que Valentino levará ao sogro uma carta com a proposta de uma empresa concorrente, o reprova por colocar estranhos na negociação (2004, p. 1099-1100); não pensa em como lidar com ele, que deve visitá-lo para entregar a carta (2004, p. 1102); mente duas vezes para ele a fim de dispensá-lo imediatamente e, portanto, não precisar tratar com ele da negociação com o administrador, além de o ofender quando ele insiste no assunto (2004, p. 1102-1104); e, finalmente, a única condição que apresenta na discussão decisiva com o filho de Olivi é que o genro não creia que a intervenção dele haja contribuído para o acordo entre eles (2004, p. 1106).

Após decidir pela assinatura do contrato, o protagonista começa a tentar culpar Valentino pela rapidez com o qual aceitou assiná-lo, seja para conseguir dormir no dia anterior à assinatura (2004, p. 1109), seja para obter algum desagravo pela ofensa que sente devido à cláusula sobre o fechamento da empresa (2004, p. 1114). Mesmo após a morte do genro, o recurso de culpá-lo continuará a ser usado por Zeno para recuperar a serenidade da qual é privado pelo contrato (2004, p. 1107). 
Assim, a rivalidade edipiana com base no contrato é o principal fator que contribui para a relação de Zeno com o genro no texto em análise, tanto antes quanto após a decisão de assiná-lo. No primeiro caso, o protagonista nega qualquer envolvimento de Valentino na negociação com o filho de Olivi para que ele não tenha nenhuma contribuição para a derrota de Zeno, a qual se realiza tanto no caso de sucumbir ao contrato quanto no caso de o rejeitar e voltar a fazer negócios desastrosos na direção da empresa. $\mathrm{O}$ incômodo com a presença do genro num disputa na qual o protagonista já se sente derrotado é explicitada no seguinte trecho sobre a primeira discussão com o filho de Olivi quanto ao contrato: "Per due ragioni io diedi un balzo: Apprendevo che [...] un membro della mia famiglia [Valentino] veniva ammesso a queste discussioni che - a quest'ora lo s'intendeva all'evidenza - non potevano terminare per me che con una sconfitta" (2004, p. 1100). Após decidir pela assinatura, Zeno arranja um modo de culpar o genro pela derrota, apesar de que ela aconteceria mesmo sem o envolvimento do parente.

Para encerrarmos a análise da terceira etapa da recaída de Zeno, notemos que o protagonista retorna ao tédio da temporalidade da nota única (2004, p. 1112), tal como no final da etapa anterior da recaída. Consideramos que o protagonista é dominado pelo tédio por se tornar incapaz de confrontar o filho de Olivi tanto pela perda da decisão final sobre os negócios que lhe é infligida pelo contrato assinado quanto pela decisão de não trabalhar na empresa porque o filho de Olivi rejeitou um salário a Zeno durante a negociação do contrato (2004, p. 1099-1100) - essa decisão é relembrada pelo protagonista quando cogita em ir ao escritório para abrir a correspondência (2004, p. 1112).

Uma vez que expusemos a nossa proposta de que o texto Un contratto apresenta a recaída de Zeno ao seu estado anterior à segunda cura parcial, complementemo-la investigando duas questões que exigem que abordemos também os demais textos das "continuações" para que sejam completamente tratadas: as limitações dessa recaída e a verificação de que ela é mantida nos demais textos.

Quanto à primeira questão, encontramos duas limitações. A primeira delas é a de que a sua recaída parece não ser total, pois ele não considera que a sua antiga doença retornou, aquela que, por exemplo, o fizera procurar o doutor S. De fato, não encontramos nenhum indício de que Zeno tenha tal opinião; pelo contrário, quando ele tenta descobrir a causa pela qual não sabe mais trabalhar, invoca uma nova doença, o envelhecimento precoce $(2004$, p. 1101). Assim, a recaída no que tange à vitória no 
comércio não parece ser acompanhada por semelhante retrocesso na vitória sobre o doutor S.: propomos que Zeno, ao imaginar estar acometido por uma nova doença - o que investigaremos ainda no presente capítulo -, não considera que a nova derrota no comércio invalida a cura da antiga moléstia e, portanto, a derrota que infligiu ao psicanalista.

A segunda das limitações em análise consiste em que tampouco Zeno volta à repetição oscilatória da abstinência e do retorno ao tabagismo, da qual sobram apenas solilóquios sem nenhuma relevância prática, como é explicitamente registrado no texto Le confessioni del vegliardo:

[...] Augusta cominciò a parlare dei miei lunghi sforzi per svezzarmi dal fummo. Si concluse, a mia lode, col convenire che la malattia era guarita visto che mai ne parlavo benché sempre fumassi. Stimo io! Avevo pur dovuto costringer la malattia a non manifestarsi altro che in un soliloquio ch'era subito dimenticato, propositi non scritti e non detti, non inseriti con alcun segno né nel calendario né nel quadrante dell'orologio, che mi lasciavano in uno stato abbastanza aggradevole di libertà. Diamine! Vivendo tanto si guarisce di tutte le malattie. (2004, p. 1142)

As únicas ocorrências da repetição oscilatória da abstinência e do retorno ao tabagismo nas "continuações" são lembranças da época da juventude do protagonista com o amigo Cima no mesmo texto (2004, p. 1135-1142). Que essa recorrência não seja retomada está de acordo com Zeno não se considerar novamente acometido pela antiga doença, já que tratava o vício de fumar como um dos principais sintomas dessa moléstia: sem ela, fumar não volta a ser um problema de saúde, o que estava na base da repetição oscilatória em análise.

A segunda questão da qual trataremos para complementar a nossa proposta da recaída de Zeno ao seu estado anterior à segunda cura parcial é a verificação de que a recaída é mantida na história dos demais textos das "continuações", o que faremos analisando se as repetições do recalcado do protagonista estão ou não em operação de acordo com o que expusemos para esse estado na segunda seção do capítulo anterior, exceto a repetição oscilatória da qual já tratamos no parágrafo anterior. Essa análise depende de que, em geral, os momentos da história dos demais textos das "continuações" que forem ulteriores ao fim da guerra também sejam ulteriores à recaída, o que é válido, conforme verificaremos na próxima seção.

Para identificar quais são as repetições do recalcado do protagonista que estão em operação, trabalharemos com os resultados que já obtivemos no segundo capítulo. Por um lado, demos, para a história ulterior à recaída nos demais textos das 
"continuações", exemplos de ocorrências: de todas as séries básicas de repetição da rivalidade contra o pai na segunda seção, da rivalidade velada na terceira seção e da repetição oscilatória dos cuidados com a saúde na quarta seção.

Por outro lado, só demos um único exemplo de ocorrência nos textos das "continuações", o do episódio de Bigioni, de alguma das séries básicas de repetição do desejo pela mãe, as quais abordamos na primeira seção do segundo capítulo. Após estudarmos as duas curas parciais de Zeno no capítulo anterior, estamos em condições de explicitar a excepcionalidade desse exemplo. Comecemos observando que a fixação de Bigioni por Antonia faz o protagonista lembrar a que teve por Ada e tentar experimentar novamente o desejo por uma mulher única. Ao fazer essa tentativa, ele imagina como seria tal mulher e conclui que ela poderia parecer única por um tempo mais ou menos longo. Ora, ao se contentar com essa restrição temporal, ele efetivamente não repete a totalidade do desejo pela mãe, que, conforme expusemos na primeira seção do segundo capítulo, Zeno exige de um amor saudável e inclui quando conclui que ama Ada. O que é repetido nesse trecho é o fetichismo, a ponto de o protagonista se referir aos pés femininos, mas apenas como exercício de imaginar uma mulher que seja única, de modo que essa recorrência é desprovida de importância prática, o que talvez seja enfatizado pela falha em repetir a totalidade do desejo pela mãe. Por fim, acrescentemos que não encontramos indício de fetichismo no erotismo concreto de Zeno, o que é especialmente relevante no caso da relação com Felicita (2004, p. 1204-1219), que é o principal tema do texto Il mio ozio.

Para encerrarmos a identificação das repetições do recalcado do protagonista que estão em operação após a sua recaída, explicitemos que a traição com a prostituta Felicita não é mais uma das substituições edipianas da traição com Carla, que terminaram desde o abandono da psicanálise, conforme verificamos na segunda seção do capítulo anterior. Na verdade, conforme examinamos na quarta seção do segundo capítulo, a relação com Felicita opera como uma repetição oscilatória dos cuidados com a saúde, o que não ocorre com as traições com Carla e com as prostitutas que a substituem. Em suma, resulta da nossa análise que, com exceção da repetição oscilatória da abstinência e do retorno ao tabagismo, a recaída de Zeno ao seu estado anterior à segunda cura parcial é mantida na história dos demais textos das "continuações". 


\subsection{A diegese e a narrativa em cada uma das "continuações": a diegese entre a segunda cura parcial e a recaída de Zeno e a articulação temporal entre a história e a narrativa}

Nesta seção, investigaremos os principais aspectos da articulação entre os tempos da história e da narrativa em cada uma das cinco "continuações". Essa investigação exige que identifiquemos as determinações temporais que cada "continuação" fornece para a história e a narração, as quais são poucas e estão bastante dispersas no texto. Como tais determinações também são necessárias para identificar os trechos que tratam da história entre a segunda cura parcial de Zeno e a sua recaída nas repetições da rivalidade edipiana, faremos essa identificação e verificaremos se esses trechos efetivamente não apresentam repetições edipianas como componentes relevantes da ação do protagonista, o que é necessário para que asseguremos os resultados obtidos na seção anterior. Em suma, abordaremos as questões expostas para cada um dos cinco textos, as quais requerem um abrangente esforço de observação que serve tanto para a validação necessária ao estudo que fizemos sobre a recaída de Zeno quanto para o estabelecimento de resultados cujas consequências serão exploradas nas próximas seções deste capítulo.

Antes de começarmos a nossa investigação, façamos um esclarecimento sobre como usaremos as determinações temporais fornecidas pelos textos: as "continuações" só nos permitem estabelecer uma cronologia aproximada, dado que são deliberadamente pouco precisas nesse aspecto, pois geralmente fornecem apenas quantos anos Zeno tinha quando certo evento ocorreu ou quantos anos se passaram entre dois eventos, exceto no caso das poucas referências a datas históricas. Coerente com esse grau de precisão, geralmente faremos os cálculos destinados à cronologia considerando apenas os anos, ainda que o resultado pudesse ser um pouco diferente se soubéssemos os meses envolvidos. Essa imprecisão não é um problema para o nosso estudo na medida em que, conforme pode ser conferido no desenvolvimento da presente seção, não nos impede de estabelecer que a narrativa trata muito pouco do período entre o fim da guerra e o afastamento voluntário do escritório, exceto no texto Un contratto; de ter uma noção da duração de alguns intervalos que nos interessam; e de explicitar a ordem dos acontecimentos quando Zeno se ocupa em fornecer as informações mínimas para esse fim.

Principiemos a nossa investigação pelo texto Un contratto, cuja história possui 
duas referências principais para estabelecermos a sua cronologia aproximada: ela inicia no fim da Primeira Guerra Mundial (2004, p. 1089), que ocorreu em novembro de 1918, e uma das conversas com Augusta para tomar uma decisão sobre o novo contrato ocorreu quando Zeno tem sessenta e três anos (2004, p. 1101), de modo que era 1920, pois ele tinha cinquenta e sete anos quando a guerra começou (2004, p. 1093), ou seja, em julho de 1914. Quanto ao tempo da narração, somos informados de que, quando Zeno escreve, se passaram sete anos desde a assinatura do novo contrato (2004, p. 1102), de modo que a narração é feita em 1927. Observemos que, no caso do texto em análise, não precisamos tratar dos trechos anteriores à recaída de Zeno, pois já foram abordados na seção anterior.

Com base nas referências fornecidas para a cronologia, dividimos a história do texto Un contratto em três períodos, dentre os quais o relato se concentra no central, o qual transcorre em 1920, começa com a apresentação do novo contrato por Valentino (2004, p. 1095-1097) e termina no dia que Zeno o assina (2004, p. 1109-1114). O primeiro período começa com o fim da guerra, em novembro de 1918, dura aproximadamente de um a dois anos, dependendo do mês no qual Valentino apresentou o novo contrato ao sogro, e ocorrem várias transformações na vida do protagonista, das quais apenas a primeira está temporalmente determinada pelo texto, de modo que não somos informados sobre a duração de nenhum dos intervalos entre as transformações: Zeno continua a conduzir os negócios herdados do pai, mas passa a fracassar nessa tarefa (2004, p. 1089-1091); o filho de Olivi assume a condução dos negócios, mas Zeno ainda age como dono da empresa (2004, p. 1091-1094); e o protagonista se afasta progressivamente do escritório porque a sua presença se torna um estorvo (2004, p. 1094-1095). Uma consequência importante dessas indeterminações para a nossa análise é que não conseguimos precisar quando o protagonista retoma as repetições edipianas, o que ocorre durante o progressivo afastamento do escritório, conforme argumentamos na seção anterior, e, portanto, devemos nos contentar com a afirmação vaga de que a retomada acontece entre o fim da guerra e dezembro de 1920.

O último período da história do texto Un contratto são os eventos posteriores ao dia da assinatura do contrato (2004, p. 1114-1115): o estudo das cláusulas do contrato; o episódio de Alfio, que cogita ser sócio da empresa; e uma nova interferência de Valentino na empresa. Dentro do grau de baixa precisão do texto, ainda conseguimos determinar temporalmente o primeiro acontecimento, pois somos informados de que ocorreu muitos dias depois da assinatura. O episódio de Alfio é simplesmente referido à 
sua atividade duradoura como pintor, de modo que, tal como no primeiro período, o grau de incerteza não se limita a meses. O terceiro evento é ainda mais impreciso, pois a única informação adicional sobre quando ocorreu é a de que Valentino ainda estava vivo. Determinaremos quando o genro morre e quando Alfio se torna pintor ao tratar do próximo texto.

Ademais, não temos como saber se o segundo evento ocorreu antes do terceiro ou vice-versa, pois não há nenhuma dependência causal entre eles. Podemos ampliar a ausência de conexões causais para o primeiro evento, pois a hipótese de ele não ser narrado ou nem mesmo haver ocorrido teria consequências irrelevantes para a narrativa dos dois últimos.

Observemos também como o período central é destacado em detrimento dos demais devido à grande diferença na velocidade da narrativa entre os três: são vinte páginas do período central, cujo tempo da história é da ordem de dias, contra sete do inicial, cujo tempo da história é da ordem de anos, e duas do final, cuja duração diegética, apesar de desconhecida, tende a ser de anos, pois não somos informados de mudanças na situação de Zeno no que tange aos negócios herdados do pai nos sete anos que separam a assinatura do contrato do tempo da narração.

Com base no destaque dado pela narrativa ao episódio intermediário da decisão de assinar o novo contrato e no fato de as determinações temporais mais precisas serem basicamente reservadas aos extremos do início da narrativa e do tempo da narração e ao episódio central, propomos que devemos valorizar a relação que os períodos inicial e final estabelecem entre os extremos e o núcleo central. De fato, podemos considerar que a determinação temporal não é importante no período inicial porque Zeno nos relata o processo que liga o fim da guerra à assinatura do novo contrato e pelo qual ele perde progressivamente o controle dos negócios herdados em favor do filho de Olivi até efetivamente entregá-lo para o seu rival. A perda progressiva serve de articulação linear pela qual se conectam as principais transformações relatadas da vida do protagonista, o que lembra a nítida progressão cronológica e causal que, conforme analisamos na penúltima seção do terceiro capítulo do presente trabalho, encerra o capítulo do romance dedicado à morte do pai.

Muito diferente da progressividade pela qual o relato liga o fim da guerra à assinatura do contrato, o que dura cerca de dois anos, são os sete anos posteriores, pois não há mais transformações no controle dos negócios, conforme sabemos pelos episódios narrados e pelo balanço que o narrador faz dos resultados do contrato (2004, 
p. 1102). Logo, a irrelevância da determinação temporal após a derrota definitiva para o filho de Olivi é de outra natureza: cada novo evento se liga antes a essa derrota do que aos demais eventos, o que justifica a ausência de dependência causal entre eles, conforme destacamos ao abordá-los inicialmente. De fato, dois deles estão baseados nas cláusulas do próprio contrato, e o último consiste em o filho de Olivi, que obteve a prerrogativa da decisão final na empresa que Zeno herdou, se submeter à supervisão dos registros da empresa por parte de Valentino.

Ademais, propomos que o período central faz a transição entre a progressividade inicial e a reiteração final. Ela resulta da retomada do exercício irrestrito das repetições do recalcado por Zeno, as quais criam sequências de eventos que se desenvolvem em paralelo ao tema central do novo contrato. A principal dessas sequências é dedicada ao afastamento de Valentino de qualquer interferência na administração da empresa por Olivi, cujo ápice são os desdobramentos provenientes das duas mentiras ditas ao genro (2004, p. 1102-1108), que eclipsa a questão do contrato por algumas páginas. Por um lado, essas sequências atravancam o desenvolvimento do tema central no sentido de que não contribuem para que Zeno decida aceitar ou recusar o contrato proposto pelo filho de Olivi. Por outro lado, as repetições de maior fôlego ganham o seu próprio desenvolvimento narrativo, tal como no exemplo que demos das duas mentiras.

Assim, a progressividade é primeiro enfraquecida pelas repetições do recalcado no período central para ser eliminada após a derrota definitiva para o filho de Olivi. Após a assinatura do novo contrato, não encontramos mais nem mesmo o desenvolvimento aparentemente linear que as repetições do recalcado podem produzir, pois o contrato bloqueou a própria capacidade de Zeno para enfrentar os seus rivais edipianos no que se refere à empresa herdada pelo pai. De fato, cada eventual oportunidade para enfrentá-los, seja buscada pelo próprio Zeno, tal como na análise das cláusulas contratuais, seja propiciada por outros, tal como nas participações de Alfio e Valentino, se torna mais uma derrota sumária do protagonista. Em suma, o período final do texto meramente acumula novas situações de bloqueio da rivalidade edipiana de Zeno que foram proporcionadas pelo contrato assinado. Por fim, as repetições bloqueadas obviamente reafirmam o tédio da temporalidade da nota única, o qual, conforme já comentamos na seção anterior, se instala no protagonista após a referida assinatura.

O próximo texto que analisaremos é Le confessioni del vegliardo. Comecemos 
abordando duas dificuldades devidas a ele estar inacabado, como os demais textos das “continuações". A primeira delas é o relato resumido (2004, p. 1118-1121) que ele apresenta dos principais acontecimentos pelos quais Zeno abandona a condução dos negócios herdados do pai, mas sem existir um novo contrato proposto pelo filho de Olivi. Uma vez que analisamos na primeira seção a versão mais completa apresentada pelo texto Un contratto, seria redundante abordar novamente esses acontecimentos. Comentemos apenas que, no estado no qual ficou na escrita inacabada, o relato de tais eventos opera basicamente como um preâmbulo à história de Alfio pelo qual é explicada a recaída de Zeno nas repetições edipianas, de modo que consideramos que não haveria razão para manter as versões resumida e a mais completa na constituição efetiva de um romance.

A segunda dificuldade é a discrepância resultante das datações finais das histórias dos filhos: no relato sobre Antonia, o narrador informa que Valentino apresentou os primeiros sintomas de envelhecimento precoce há um ano (2004, p. 1151) e, no relato sobre Alfio, comenta que queria contar sobre eventos ocorridos há algumas semanas (2004, p. 1140) se referindo ao almoço com Cima, do qual o genro participa sem nenhuma indicação de estar doente (2004, p. 1144). Como a contradição entre referências temporais não é um procedimento típico de Svevo, consideramos mais plausível que seja causada pelo estado inacabado no qual se encontram os textos das “continuações" e que poderia ser trivialmente resolvida durante o processo de revisão retirando Valentino do episódio do almoço, ajustando as duas datações entre si ou introduzindo um hiato no tempo da narração dos dois relatos. Dado que a nossa investigação é afetada apenas pontualmente por tal escolha e não almeja uma grande precisão temporal, optaremos por uma das revisões mencionadas apenas a fim de simplificar a nossa exposição. Com base em tais considerações, convencionaremos para o presente trabalho que o almoço com Cima antecedeu a doença fatal de Valentino em poucas semanas, o que ainda conserva o contraste desejado pelo narrador entre o passado recente de tal acontecimento e o período remoto da sua juventude, quando caçou com Cima.

A segunda dificuldade já introduziu referências cruciais para a cronologia aproximada do texto Le confessioni del vegliardo. Elas são relativas à enunciação do narrador, a qual começa em 4 de abril de 1928, de acordo com a data que está no início do texto (2004, p. 1116). Pelo que já apresentamos ao tratar da dificuldade em análise, o almoço com Cima e o envelhecimento precoce de Valentino ocorreram um ano antes, 
ou seja, por volta de março e abril de 1927. Supomos que o genro morre ainda no primeiro semestre do mesmo ano, já que a indicação mais próxima a esse respeito registra que o seu corpo se tornou o de um velho em poucas semanas (2004, p. 1151). Encontramos mais uma referência importante entre a doença fatal do genro e o tempo da narração: três ou quatro meses após a morte de Valentino, Antonia finalmente decide aceitar o convite para morar com os pais (2004, p. 1156-1157), de modo que a filha enlutada e o neto moram com Zeno desde o segundo semestre de 1927, ou seja, há alguns meses apenas.

As demais referências importantes do texto Le confessioni del vegliardo para estabelecermos a sua cronologia aproximada são a juventude de Zeno, época que se destaca do restante da diegese e na qual ele conhece Cima (2004, p. 1135), a reforma escolar que é aprovada em 1923 e é implementada por Giovanni Gentile - conforme nos informa uma das notas ao texto (2004, p. 1568) -, logo após a qual Alfio abandona a escola (2004, p. 1122), e a participação da Itália na guerra, que inicia em maio de 1915 e acaba com o fim do conflito em novembro de 1918. A última referência é importante tanto porque Zeno é afastado do convívio com os filhos quando a Itália entra no conflito, como é afirmado no terceiro romance de Svevo (2004, p. 1070), e só os reencontra depois que a guerra termina $(2004$, p. 1121) quanto porque, durante esse período, Antonia tem um envolvimento amoroso com Eugenio, o qual morre em combate poucos dias antes do armistício, e aceita noivar com o irmão dele, Valentino, logo após a morte de Eugenio (2004, p. 1149-1150).

Com base na exposição que fizemos das referências fornecidas para a cronologia, tratemos dos tempos da história e da narrativa. Na verdade, consideramos que a história do texto Le confessioni del vegliardo não é objeto de um relato único, pois nos parece ser dividido em quatro narrativas consecutivas sobre Zeno, as quais o narrador não se empenha em unificar: a operação de rejuvenescimento (2004, p. 1117 1118); a condução dos negócios herdados do pai (2004, p. 1118-1121); a relação com Alfio (2004, p. 1121-1146); e a relação com Antonia (2004, p. 1146-1157).

A operação de rejuvenescimento é ligada ao próprio retorno de Zeno à escrita (2004, p. 1118) e provavelmente antecede o início desse retorno em semanas ou meses. Como a operação é mais importante para o surgimento do narrador do que para a construção do protagonista, não a consideraremos na presente seção e trataremos dela na próxima. Quanto à condução dos negócios herdados do pai, retomemos as referências temporais que já estabelecemos ao tratar do texto Un contratto: Zeno abandona 
gradualmente a condução dos negócios entre o fim da guerra e algum mês de 1920. Além da história desse abandono, também são relatadas as participações de Alfio e Valentino nos negócios conduzidos pelo filho de Olivi. Como a participação do genro não é melhor determinada temporalmente, ela pode ocorrer até a sua morte, ou seja, até 1927.

O relato da passagem de Alfio pelo escritório fornece uma informação que nos importa para a narrativa seguinte, pois declara que Alfio começa a se dedicar à pintura após parar de frequentar a escola (2004, p. 1120) e, portanto, torna-se pintor em $1923 \mathrm{ou}$ depois.

As demais narrativas relatam a relação de Zeno com o filho e a filha. Recorrendo à cronologia aproximada que resulta das referências temporais que expusemos, estudemos essas narrativas identificando e analisando os trechos anteriores à recaída de Zeno e estabelecendo quais são os limites temporais da história de cada uma delas.

No tocante à narrativa sobre Alfio, identificamos quatro trechos que são anteriores à recaída. O primeiro deles é a convivência de Zeno com Cima na juventude (2004, p. 1135-1142), que é até mesmo anterior à primeira cura parcial de Zeno. Inclusive lembremos que, conforme já comentamos no final da seção anterior, esse trecho apresenta as únicas ocorrências da repetição oscilatória das tentativas fracassadas de parar de fumar nas "continuações".

O segundo dos trechos em análise é o do relato de como Zeno tentou evitar as efusões afetuosas e as imposições de patriarca a fim de impedir que a relação com o pai se repetisse com os filhos (2004, p. 1124-1125). Ele faz referência explícita à primeira infância de Alfio e apresenta uma situação de subordinação dos filhos a Augusta e Zeno mais compatível com a época anterior à guerra, já que o caçula Alfio tem 15 anos quando o conflito termina (2004, p. 1121), e, portanto, trata principalmente de um período anterior à segunda cura parcial de Zeno.

Os demais trechos em análise são posteriores à guerra: o retorno de Alfio para casa graças ao fim do conflito (2004, p. 1121) e o subsequente envolvimento do filho com o comunismo (2004, p. 1126). Eles não parecem conter ocorrências de repetições edipianas, o que é reforçado por esses eventos ligados a novembro de 1918 serem seguidos por desentendimentos entre Zeno e Alfio que ocorrem muito tempo depois, em 1923 ou ainda mais tarde. No primeiro caso, o narrador faz uma transição (2004, p. 1121-1122) por meio de algumas frases referentes a um passado indeterminado ou até 
ao presente da narração para, quando finalmente relatar um evento específico, entregar a narrativa do dissídio devido ao fato de o filho abandonar a escola, ou seja, um evento de 1923. No segundo caso, Alfio substitui o comunismo pelo ideal da personalidade, o qual foi o motivo para um sério dissídio entre Zeno e o filho, a ponto de este receber uma ameaça de ser deserdado (2004, p. 1126-1127). Como não somos informados sobre a duração da adesão comunista nem é mencionado um desentendimento tão grave como esse quando Zeno trata do abandono da escola, consideramos que este é o primeiro dentre os dois dissídios.

Assim, dos quatro trechos anteriores à recaída de Zeno na narrativa sobre Alfio, apenas dois deles, cada qual sem ultrapassar o tamanho de um único parágrafo, são do período intermediário no qual já ocorrera a segunda cura parcial de Zeno sem que ele ainda houvesse sofrido a recaída nas repetições da rivalidade edipiana, as quais consideramos ausentes do protagonista conforme o relato feito em ambos os trechos.

No que tange à narrativa sobre Antonia, identificamos cinco trechos que são anteriores à recaída. Os dois primeiros deles são o das características que a filha possui desde jovenzinha (2004, p. 1146-1147) e o dos gastos dos pais com as despesas de Antonia com a própria beleza (2004, p. 1148). Como a filha torna-se noiva e casa-se com Valentino logo após o fim da guerra e Zeno não conviveu com ela durante a participação italiana no conflito, consideramos que esses trechos se referem basicamente ao período anterior a essa participação e, portanto, anterior à segunda cura parcial de Zeno. O terceiro trecho é o do breve relacionamento da filha com Eugenio (2004, p. 1148-1150). Como o que importa nesse relato ocorre durante o período que Zeno está afastado da família devido à guerra, há poucos enunciados que envolvem o protagonista, os quais não nos parecem conter manifestações de rivalidade edipiana.

O quarto trecho anterior à recaída é o da posição contrária de Antonia à liberação dos costumes femininos depois da guerra (2004, p. 1147-1148). Dado que há referências a Antonia ainda viver com os pais, consideramos que se trata do período no qual Zeno continua sob o efeito da segunda cura parcial. Como elementos mais claramente hostis desse trecho de dois parágrafos, identificamos duas comparações e o uso do termo "escravidão"; no entanto, eles podem ser entendidos como sendo devido apenas ao narrador, uma hipótese que exploraremos na próxima seção. Mesmo que eles fossem inicialmente propostos pelo protagonista, não remetem a nenhuma consequência nas suas ações, de modo que se tratariam de manifestações de rivalidade edipiana sem importância prática. 
O último trecho anterior à recaída é o do noivado e do casamento de Antonia com Valentino antes que o genro fosse fatalmente acometido pelo envelhecimento precoce (2004, p. 1150-1151), cuja história só parcialmente antecede a recaída, pois o casamento dura até a morte do genro, em 1927, enquanto a recaída é anterior a 1921. Consideramos que só há dois sentimentos hostis que podemos atribuir ao protagonista anterior à recaída com o mínimo de segurança: o desgosto que sente por Valentino se casar com Antonia e a impaciência com o modo demasiadamente detalhado pelo qual o genro conta qualquer notícia. Podemos argumentar que, por si só, esses sentimentos manifestam uma antipatia normal por outras pessoas, o que é especialmente válido para o caso do casamento, já que são relatados comportamentos compatíveis em outras pessoas, conforme decorre da reação de Augusta ao questionamento do protagonista sobre Valentino ser o marido para a bela filha deles: "Augusta fece un gesto di rassegnazione per significare che non era stata lei a sceglierlo. Ma poi mossa dal desiderio di essere d'accordo con tutti e viver quieta aggiunse: - Promise però d'imprendere una cura dimagrante. È, se lo guardi bene, non brutto" (2004, p. 1150). Assim, não só Augusta precisa se esforçar para dizer que ele não é feio, mas também o próprio genro reconhece que precisa emagrecer.

Mesmo que o desgosto por Valentino se casar com Antonia fosse uma ocorrência da rivalidade edipiana de Zeno, podemos constatar a sua irrelevância prática no período anterior à recaída observando que não somos informados de nenhuma tentativa do protagonista para impedir o casamento. No que se refere ao falatório do genro, a reação de Zeno sofre uma mudança: "Io, poi, m'abituai a stare ben attento alla sua voce alla quale dapprima sfuggivo" (2004, p. 1150). Consideramos que essa transformação, para a qual o trecho não dá nenhuma indicação de quando ocorreu, pode ser compreendida como a passagem da hostilidade aberta, mesmo que tácita, das tentativas diretas de escapar à chatice de escutar o genro para a hostilidade velada da escuta aparentemente interessada que visa somente abreviar ao máximo o falatório de Valentino.

Logo, três dos cinco trechos que antecedem a recaída de Zeno na narrativa sobre Antonia são do período intermediário no qual já ocorrera a segunda cura parcial de Zeno sem que ele ainda houvesse sofrido a recaída nas repetições da rivalidade edipiana, e consideramos que nenhum deles apresenta alguma ocorrência do recalcado por parte do protagonista e que, mesmo que o fizesse, seria desprovida de importância prática. 
Uma vez que tratamos dos trechos anteriores à recaída de Zeno, verifiquemos se a configuração resultante das articulações dos tempos da história e da narrativa do texto Le confessioni del vegliardo coincide com alguma daquelas que já obtivemos como resultado da investigação dos demais textos narrados por Zeno sob o efeito da compulsão à repetição do recalcado, o que exclui a carta que encerra o diário, conforme propomos no capítulo anterior, e, caso não coincida com nenhuma delas, estabeleçamos qual é a principal característica distintiva da referida configuração para o texto em análise.

Já obtivemos configurações distintas das articulações temporais para três blocos da narrativa de Zeno desde o terceiro capítulo do presente trabalho: a autobiografia, o diário e o texto Un contratto. Como já argumentamos no segundo capítulo e reforçamos nos capítulos seguintes, as temporalidades da repetição do recalcado e da nota única são cruciais para o romance publicado e para as "continuações", o que inclui tanto os três blocos mencionados quanto o texto Le confessioni del vegliardo e o restante das "continuações". A principal diferença entre as configurações em análise está na participação das temporalidades linear e de onda: a primeira sustenta um embate com a segunda na autobiografia, se torna residual em favor do amplo predomínio da segunda no diário e prevalece na progressividade inicial do texto Un contratto até gradualmente ceder a primazia para as repetições da rivalidade edipiana, as quais, como já exploramos amplamente no presente trabalho, estão articuladas com o acaso da temporalidade de onda por não serem reconhecidas pelo protagonista-narrador.

Consideramos que o texto Le confessioni del vegliardo não se constitui segundo uma temporalidade linear, de modo que só poderia coincidir com o diário. De fato, tanto as narrativas desse texto são tão fracamente vinculadas entre si que o entendimento do enredo de cada uma delas não exige a leitura das demais quanto cada uma delas acumula episódios que geralmente não estão conectados pelas ações dos personagens. Para aumentar ainda mais o afastamento da temporalidade linear, no caso das narrativas maiores, sobre Alfio e Antonia, alguns dos principais eventos que causam desdobramentos na história não pertencem à necessidade interna do relato ou até mesmo chegam ao extremo de serem pura e simplesmente acidentais. Assim, quando Zeno finalmente consegue se reconciliar com o filho e, portanto, afastar a sua relação com Alfio daquela que teve com o próprio pai, ele mesmo provoca o rompimento definitivo entre ambos por causas que extrapolam o propósito de reconciliação sem que o narrador 
tente articulá-las com tal propósito: apesar de não ter interesse por pintura, passa a gostar do quadro que comprara do filho apenas para servir de instrumento para reconciliá-los, mas se ressente quando Alfio rejeita o modo pelo qual ele aprecia o quadro (2004, p. 1128-1135); e ofende o filho numa disputa de zombarias com outra pessoa (2004, p. 1143-1145), um amigo que reencontrou totalmente por acaso e que não via há quase cinquenta anos (2004, p. 1135). No tocante à narrativa sobre Antonia, o seu principal excesso de virtude, o luto exagerado de quase um ano por Valentino, é resultado do envelhecimento precoce de Valentino, ou seja, o acaso da doença ainda é reforçado por não ser uma enfermidade comum.

Ao não ser constituído segundo a temporalidade linear e acatar a debilidade das conexões e o acaso da temporalidade de onda, o texto Le confessioni del vegliardo se aproxima da elaboração das articulações dos tempos da história e da narrativa no diário; apesar disso, observemos que o diário possui uma característica importante em comum com a autobiografia e o texto Un contratto que não encontramos no texto em análise: a sucessão temporal está presente em grande medida nos três blocos narrativos que já analisamos, sendo até mesmo a base da identificação das divisões do diário, mas é estruturalmente descartada na divisão da história nos relatos consecutivos sobre a condução dos negócios herdados do pai, a relação com Alfio e a relação com Antonia. De fato, retomando a cronologia aproximada que estabelecemos, obtemos as seguintes delimitações temporais para os três relatos: a primeira narrativa começa logo após o fim da guerra e prossegue até um período indeterminado no qual Valentino ainda está vivo, que pode até mesmo ser 1927; a segunda retorna aos anos anteriores à guerra para tratar da relação de Zeno com os filhos ainda crianças - além de incluir um retorno enorme até a convivência de Zeno com Cima na juventude - e prossegue até um período indeterminado de convivência com o filho após o almoço com Cima, o que virtualmente alcança o próprio presente da narração, já que não somos informados de mudanças na relação com Alfio; e a terceira retorna novamente aos anos anteriores à guerra para tratar da filha ainda jovenzinha e avança até alguns meses após a morte de Valentino, quando a enlutada Antonia aceita morar com os pais. Tal como no segundo caso, o primeiro e o terceiro relatos virtualmente alcançam o próprio presente da narração, pois não somos informados de mudanças no assunto principal de que tratam.

Em suma, o texto Le confessioni del vegliardo rejeita a primazia da sucessão temporal em favor de narrativas desenvolvidas independente e paralelamente no tempo da história, que acompanham o protagonista do fim da guerra ou da infância dos filhos 
até alcançar uma situação que não é mais modificada e se prolonga virtualmente até o narrador.

Além da desvalorização da sucessão temporal em si mesma, propomos que tal desvalorização em favor de narrativas independentes e paralelas imediatamente torna muito relevante a comparação entre esses relatos, o que nos induz a considerar especificamente a notória semelhança - frente à independência entre as narrativas entre os finais das suas histórias serem situações que Zeno não consegue mais modificar: a plena entrega da condução dos negócios herdados do pai para o filho de Olivi, o desentendimento definitivo com Alfio e o luto exagerado de Antonia. São todas situações que Zeno desejaria reverter, mas parece incapaz de fazê-lo. Nesse sentido, o caso mais explicitado pelo texto Le confessioni del vegliardo é o das relações com o filho: "Io feci di tutto per migliorarle, soltanto non seppi dirgli che la sua pittura mi piacesse. M'avevo dato della bestia, sia pure solo in pittura" (2004, p. 1145). Logo, se formou um impasse, pois o protagonista precisaria convencer Alfio de que gosta da sua pintura para reatar com ele, mas não consegue fazê-lo sem que o rival se desculpe por lhe haver ofendido. De modo menos explícito, Zeno desejaria que a filha abandonasse o luto exagerado que dedica ao rival Valentino, mas não recebemos nenhum indício de que isso possa acontecer, apesar do luto já durar vários meses quando o relato é escrito. Por fim, que o protagonista não vá mais ao escritório (2004, p. 1121) de modo a entregar definitivamente o controle dos negócios herdados do pai ao filho de Olivi é mais uma derrota a um rival edipiano para a qual não somos informados de nenhum empenho de Zeno que possa reverter um resultado tão desfavorável. Nesse último caso, o impasse do protagonista é bem explicitado no texto Un contratto, conforme expusemos no final da seção anterior. Avaliamos que há uma conexão ainda mais elaborada entre a desvalorização da sucessão temporal e a incapacidade de duração indeterminada para exercer certas repetições do recalcado, mas estaremos em condições de estabelecer essa conexão com mais clareza ao tratarmos do narrador, de modo que adiaremos tal tarefa para a próxima seção.

O próximo texto que analisaremos é Umbertino. Comecemos apresentando as principais referências para a cronologia aproximada desse texto. Há uma referência a Zeno ter setenta anos quando a sua relação com Carlos se torna "sincera" no sentido de que relata supostos casos extraconjugais para o sobrinho (2004, p. 1186), de modo que essa etapa da relação começa em 1927. Além dessa referência, só encontramos mais uma que é fornecida pelo próprio texto Umbertino. Ela é dada pelo narrador, o qual 
declara que o seu neto tem sete anos e meio (2004, p. 1158), mas essa informação só é relevante no contexto da nossa análise se soubermos precisar o tempo da narração.

Com efeito, as referências fornecidas pelo próprio texto Umbertino são insuficientes para estabelecermos a sua cronologia aproximada. Assim, recorramos a duas referências temporais que são fornecidas apenas pelo texto Le confessioni del vegliardo: conforme expusemos ao abordá-lo, Valentino morre no primeiro semestre de 1927 e a filha enlutada e o neto se mudam para morar com Zeno no segundo semestre do mesmo ano.

No tocante à narração, ela não pode ser anterior ao segundo semestre de 1927 , pois vários episódios acontecem quando Antonia e Umbertino já estão morando com Zeno, conforme exporemos na continuação da análise do texto Umbertino. Desse modo, a narração pode ocorrer tanto em abril de 1928, tal como o texto Le confessioni del vegliardo, quanto nos últimos meses de 1927, o que é compatível com o tempo da narração das demais "continuações", o qual identificamos simplesmente como sendo 1927. Por fim, descartando a hipótese pouco plausível de que o texto em análise tenha um tempo da narração distinto das demais "continuações" sem fornecer nenhum indício disso e retomando a informação dada pelo narrador de que Umbertino tem sete anos e meio, concluímos que o neto de Zeno nasceu em 1920.

Uma vez que elencamos as referências para uma cronologia aproximada do texto Umbertino, tratemos dos tempos da história e da narrativa, começando pela proposta de que a sua história, tal como a do texto Le confessioni del vegliardo, não é objeto de um relato único, pois consideramos que está dividida em cinco narrativas sucessivas sobre Zeno, as quais o narrador não se empenha em unificar: os relacionamentos com o neto (2004, p. 1158-1167) e com Bigioni (2004, p. 1167-1181), o episódio da gafe com a filha (2004, p. 1181-1183) e as relações com Carlo (2004, p. 1183-1191) e Renata (2004, p. 1191-1196).

Iniciemos o nosso estudo das cinco narrativas identificando os trechos anteriores à recaída de Zeno. Ora, não encontramos nenhum trecho em tal condição, pois todos são ulteriores a 1920. Quanto à narrativa sobre Umbertino, baseamos essa afirmação no fato de que todos os seus episódios supõem que ele anda, fala ou entende o que lhe falam, de modo que o neto já precisaria ter um ano ou mais de idade, e, portanto, todos ocorrem em 1921 ou depois. No tocante ao relato sobre Bigioni, a situação é equivalente: como todos os seus episódios supõem a morte de Valentino, nenhum deles ocorre antes de 1927. A mesma suposição obviamente se aplica ao 
episódio da gafe com a filha, no qual Antonia está de luto.

No que tange à narrativa sobre Carlo, o principal episódio é o da relação de sinceridade com o sobrinho, a qual começa em 1927, conforme uma das referências que identificamos para a cronologia aproximada para o texto Umbertino. Como não recebemos nenhum indício de que os demais episódios ocorram em circunstâncias diferentes que justificassem a suposição de que transcorreriam em outros períodos da história, simplesmente consideramos que a narrativa em questão não possui eventos anteriores a 1921.

Por fim, o relato sobre Renata é dedicado ao período no qual ela trabalha na casa de Zeno, o qual começa quando Antonia volta a morar com os pais (2004, p. 11911192), ou seja, em 1927. O único trecho que pode ser anterior ao retorno de Antonia trata de como o Fortunato se tornou motorista de Zeno pouco tempo antes de todos perceberem que ele e Renata eram amantes (2004, p. 1193-1194): o trecho relata a morte do último cavalo da família Cosini e a subsequente instrução como motorista do cocheiro Fortunato, a qual durou vários meses. Assim, a nossa hipótese mais extrema é de que os eventos mais antigos da narrativa em questão seriam de 1926. Em suma, não encontramos nenhum evento anterior à recaída de Zeno em nenhuma das cinco narrativas do texto Umbertino.

Reencontramos no texto Umbertino as três características que destacamos a respeito da elaboração das articulações temporais do texto Le confessioni del vegliardo. A primeira delas é a rejeição da temporalidade linear em favor da temporalidade de onda, pois novamente as narrativas que compõem o texto são tão debilmente vinculadas entre si a ponto de o entendimento do enredo de cada uma delas não exigir a leitura das demais. Além disso, o episódio da gafe com Antonia é muito breve para ganhar um desenvolvimento narrativo, e os relatos sobre Umbertino, Carlo e Renata acumulam episódios que geralmente não estão conectados pelas ações dos personagens.

A segunda das características que reencontramos no texto Umbertino é a desvalorização da sucessão temporal. Ora, com exceção da narrativa sobre o neto de Zeno, que abrange vários anos, as demais estão basicamente concentradas no período entre a morte de Valentino e o presente da narração, conforme podemos constatar a partir das nossas considerações sobre não haver trechos anteriores à recaída de Zeno nesse texto. Até mesmo a narrativa sobre o neto possui uma porção relevante da sua história nesse período. Logo, consideramos que as cinco narrativas do texto Umbertino retomam em grande medida o mesmo período da vida do protagonista em detrimento de 
abarcá-las conjuntamente numa única sucessão temporal.

A terceira das características que reencontramos no texto Umbertino são as situações finais de cada história serem tais que Zeno parece incapaz de revertê-las ainda que deseje fazê-lo. Tal como constatamos em relação à narrativa sobre Antonia no texto Le confessioni del vegliardo, o episódio da gafe de Zeno com a filha afirma a incapacidade do protagonista de afastá-la do luto exagerado que dedica a Valentino. Em íntima ligação com o prolongamento indeterminado desse luto, está a convivência com o neto na própria casa, o que determina que o protagonista permaneça sujeito a restrições na sua liberdade tanto no estúdio quanto nos passeios diários, as quais já apresentamos na segunda seção do segundo capítulo.

No caso das narrativas sobre Carlo e Renata, Zeno perde oportunidades de cunho erótico que tais relações lhe propiciavam. Quanto a Carlo, o protagonista desenvolve uma competição sexual com ele na qual se gaba de suas supostas proezas eróticas, conforme já mencionamos na segunda seção do segundo capítulo, mas é incapaz de manter a disputa após o susto que Carlo lhe prega num jantar no qual insinua que o tio não era fiel a Augusta (2004, p. 1187-1188). No tocante a Renata, Zeno a deseja tal como um pai edipiano à própria filha, como consideramos ser sugerido no seguinte trecho: “Come seppi associarmi all'amore per le bestie di Augusta, così mi fu facilissimo di accompagnarla anche nell'amore a Renata. Certo in me non si muove altro che un amore paterno vecchio come sono" (2004, p. 1192). Nesse contexto, a empregada se tornar amante do motorista do protagonista se torna equivalente para Zeno à convivência com a filha enlutada no sentido de que ele é submetido à humilhante derrota de presenciar, cotidianamente e em sua própria casa, a preferência permanente de ambas pelos respectivos rivais edipianos.

Por fim, Bigioni dá a Zeno a esperança de que a filha se case novamente, e o protagonista tenta manter essa esperança a todo custo, o que até mesmo cria a única ocorrência de uma repetição oscilatória e assintótica, conforme analisamos na penúltima seção do segundo capítulo. Ora, a realização de tal esperança justamente permitiria que Zeno se liberasse tanto da humilhante derrota do luto exagerado da filha quanto das restrições à própria liberdade que a convivência com o neto lhe impõe. Em vez disso, o afastamento de Bigioni reafirma a incapacidade de Zeno de realizar o desejo de se liberar de tais situações desfavoráveis.

O penúltimo texto que analisaremos é Il mio ozio. A nossa análise começa pela identificação das principais referências para a cronologia aproximada desse texto. Como 
todas estão referidas ao presente da narração, determinemos quando ocorre a narração recorrendo a dois trechos. No primeiro deles, o narrador afirma estar convencido que os conselhos do filósofo Herbert Spencer sobre o desenvolvimento infantil também valeriam para ele próprio, ainda que esteja com setenta anos (2004, p. 1201). O segundo trecho se refere ao episódio com Felicita: "È una storia di tre anni fa e contavo dunque 67 anni” (2004, p. 1203). Logo, ambos os trechos indicam que a narração é feita em 1927, e o segundo deles também serve como base para afirmarmos que Felicita se tornou a última amante de Zeno em 1924.

As demais referências para a cronologia aproximada do texto em análise são dedicadas a cuidados com a saúde: o narrador conta que no último verão teve uma pressão sanguínea muito alta (2004, p. 1198) e que começou uma mudança de hábitos alimentares havia cerca de cinco anos, a qual foi modificada por Carlo depois de três anos (2004, p. 1199-1200). Assim, a referência mais antiga é a 1922. Como a recaída de Zeno é anterior a esse ano, resulta diretamente da identificação das referências para a cronologia aproximada que não encontramos eventos anteriores a essa recaída no texto Il mio ozio.

Uma vez que identificamos as referências para uma cronologia aproximada do texto Il mio ozio, tratemos dos tempos da história e da narrativa. Ao contrário dos dois textos anteriores que analisamos, não há uma divisão clara entre as narrativas no texto em análise, pois a leitura dos episódios sobre a relação com as mulheres após o término com Felicita (2004, p. 1220-1221) supõe que se conheça o episódio da amante (2004, p. 1202-1219), o qual, por sua vez, supõe a leitura dos cuidados com a saúde dos diversos órgãos (2004, p. 1198-1201). Logo, consideraremos que se trata de uma única narrativa.

Como já argumentamos que não há trechos anteriores à recaída de Zeno, abordemos as três características que destacamos a respeito da elaboração das articulações temporais do texto Le confessioni del vegliardo. Dado que tratamos do texto Il mio ozio como uma única narrativa, avaliaremos tais características no interior da mesma. Comecemos pela desvalorização da sucessão temporal. Até o episódio de Felicita, a desvalorização é grande, como podemos constatar pela observação de alguns eventos que citamos na ordem adotada na narrativa: o tratamento da pressão sanguínea remonta ao verão passado, o qual não sabemos há quantos meses se passou; vários cuidados, tal como a dieta láctea, são narrados no presente, mas não sabemos há quanto tempo Zeno os adota, de modo que algum deles poderia até mesmo ser anterior ao último verão; retorna cerca de cinco anos para relatar uma mudança de hábitos 
alimentares, a qual foi modificada depois de três anos; e retorna novamente, agora para três anos antes da narração, para relatar o envolvimento com Felicita e as suas consequências. Ademais, não sabemos quanto durou a relação com a amante, de modo que não sabemos se e quando se cruzam as histórias dos tratamentos com as da relação de Zeno com as mulheres após Felicita se tornar sua amante.

A partir do episódio da relação com Felicita, a sucessão temporal é retomada em alguma medida, pois Zeno narra consecutivamente como a relação inicia (2004, p. 1203-1205), se estabelece (2004, p. 1205-1207), termina (2004, p. 1207-1219) e quais são as suas consequências (2004, p. 1219-1221); no entanto, essa retomada é um pouco limitada, pois apenas o relato do término ultrapassa alguns parágrafos e também é construído de modo a dar primazia à exposição cronológica dos acontecimentos. De qualquer modo, reconhecemos esses trechos como sendo o caso de maior adoção da sucessão temporal dentre os textos Le confessioni del vegliardo, Umbertino, Il mio ozio e Prefazione. Voltaremos a tratar dessa retomada contundente da exposição cronológica na última seção.

A segunda das características em análise é a rejeição da temporalidade linear em favor da temporalidade de onda. Pela análise que fizemos sobre a sucessão temporal, já podemos suspeitar que essa rejeição seja válida para a parte anterior ao episódio de Felicita. De fato, apesar do tema comum dos cuidados pela saúde, consideramos que há apenas acumulação entre os tratamentos dispensados aos diferentes órgãos.

No tocante ao restante do texto, o início, o estabelecimento e as consequências da relação com a amante são trechos muito pontuais para apresentarem um desenvolvimento relevante da temporalidade linear, de modo que apenas o trecho sobre o fim da relação poderia ser uma retomada relevante dessa configuração temporal, mas avaliamos que isso não ocorre. Com efeito, se aderimos à perspectiva do narrador, a qual exclui de consideração as repetições da rivalidade edipiana, o final da relação com Felicita se torna em grande medida moldado pelo fluxo inesperado e debilmente causal dos acontecimentos, a mesma conclusão que obtivemos no final da segunda seção do capítulo anterior a respeito das três seções finais do diário de Zeno: o encontro com Misceli (2004, p. 1207-1213) não poderia constituir nenhuma surpresa, pois o mais provável obviamente era que uma amante paga tivesse outros clientes, de modo que a reação de Zeno de, por rancor, anunciar a Felicita que não deseja mais vê-la e de entrar numa relação competitiva com Misceli é efetivamente inesperada; a confirmação da decisão de terminar com a amante (2004, p. 1213-1214) se baseia num comentário do 
médico de Misceli que é comunicado a Zeno de modo meramente casual; a ida do irmão de Felicita à casa do protagonista para entregar os cigarros encomendados, receber por eles e cobrar o resto da mensalidade combinada com a irmã (2004, p. 1214-1217) é perfeitamente coerente com a avidez pela qual a narrativa caracteriza os irmãos, mas o fato de o episódio estar fundado numa encomenda que obviamente servira apenas de pretexto reforça, ainda que de modo que independe do narrador, a casualidade geral que perpassa os acontecimentos em análise; e a iniciativa de Zeno de reencontrar a amante (2004, p. 1217-1219) causa surpresa e assinala a incoerência das atitudes do protagonista na medida em que ele justifica essa iniciativa com razões financeiras apesar de haver justificado tanto o começo do relacionamento com Felicita quanto a decisão de terminá-lo com o empenho em evitar a morte pela comprovação de que permanece apto ao ato sexual, necessário à reprodução.

A terceira e última das características em análise é a situação final da história ser tal que Zeno parece incapaz de revertê-la ainda que deseje fazê-lo. Tal como nos casos da assinatura do novo contrato com o filho de Olivi e da incapacidade de se reconciliar com Alfio, o impasse provocado por Felicita é claramente explicitado pelo narrador. De fato, Zeno não só não teve mais nenhuma amante depois dela, mas também foi educado por ela, como escreve: "Ma, dopo di lei non ci fu posto ad altri amori. [...] Alla carriera di vegliardo cui sono ora condannato, io fui educato da Felicita. Io appena ora so che in amore io non valgo altro che per quello che pago" (2004, p. 1219-1220). O protagonista não teve novas amantes porque a educação que recebeu de Felicita lhe impede de acreditar que alguma mulher possa desejá-lo, de modo que é lançado a um impasse sexual, conforme expusemos no final da quinta seção do segundo capítulo.

Em geral, o impasse sexual de Zeno o torna simplesmente incapaz de dar a mínima expansão ao seu desejo pelas mulheres. Mesmo quando, no episódio de Anfora (2004, p. 1221), excepcionalmente se entrega à admiração do corpo feminino a ponto de que o seu desejo possa ser percebido, quem o percebe não é a jovem desejada, mas uma velha que a acompanha: "E fu questa vecchia che passandomi accanto e guardandomi, mormorò: - Vecchio satiro. Mi dava del vecchio. Chiamava la morte" (2004, p. 1221). Como o protagonista associou o desejo sexual ao propósito de evitar a morte, a expressão "velho sátiro" não só representa uma repressão à manifestação do desejo de Zeno, mas também afirma a velhice do protagonista mesmo reconhecendo a sua disposição para a sexualidade, o que resulta justamente na desqualificação da maneira encontrada pelo protagonista para evitar a morte. 
O último texto que analisaremos é Prefazione, começando pela identificação das principais referências para a sua cronologia aproximada. Como quase todas estão referidas ao presente da narração, determinemos quando ocorre a narração. Tal como no texto Il mio ozio, ela ocorre em 1927, pois o episódio da moça que Zeno confunde com a filha do velho Dondi, que é de abril do mesmo ano da narração (2004, p. 1222), ocorre quando o narrador tem setenta anos (2004, p. 1233), conforme somos informados no episódio do bêbado cantor. Essa informação sobre a idade de Zeno está referida ao momento no qual ele se destaca do presente, o que justamente acontece por meio da confusão com a filha do velho Dondi, da qual trataremos na próxima seção.

Com base na determinação do tempo da narração, inferimos que o episódio que exemplifica a questão da medição do presente (2004, p. 1229-1230) é da primavera de 1926 ou 1927, pois o narrador declara que ele ocorreu na primavera passada sem esclarecer se a narração é feita na mesma estação do epísódio ou em outra estação, e que os acontecimentos referentes ao violino (2004, p. 1231) vão de 1925, quando o protagonista parou de tocá-lo, a alguns dias antes da narração, quando Augusta retirou o violino do seu lugar no escritório de Zeno.

A última das referências que estamos analisando é a juventude de Zeno, na qual se passam o episódio da filha do velho Dondi (2004, p. 1223) e o trecho sobre o livrinho de anotações do seu pai (2004, p. 1230-1231).

Uma vez que elencamos as referências para uma cronologia aproximada do texto Prefazione, tratemos dos tempos da história e da narrativa, iniciando pela ressalva de que a atividade narrativa nesse texto não ganha um desenvolvimento autônomo, pois está subordinada ao empenho de Zeno de escrever um prefácio para os seus relatos autobiográficos. Tal configuração exige que incluamos, em alguma medida, o empenho prefaciador de Zeno nas nossas considerações sobre a história e a narrativa, a começar por não dividirmos o texto em vários relatos, pois estão todos a serviço do prefácio que Zeno se propõe a escrever.

Enumeremos os relatos aos quais Zeno recorre ao construir o prefácio em análise: o episódio da moça que ele confunde com a filha do velho Dondi (2004, p. 1222-1224), no qual o protagonista recorda o episódio da filha de Dondi; uma conversa com Carlo (2004, p. 1225); o episódio que exemplifica a questão da medição do presente; o livrinho de anotações do seu pai; os eventos referentes ao violino; e os acontecimentos costumeiros que voltam a ocorrer no próprio instante da escrita (2004, p. 1232-1234). Ainda não abordamos as determinações temporais da conversa com o 
sobrinho nem do último relato. Quanto à conversa, ela não está especificada temporalmente, mas não deve ultrapassar alguns anos, já que Zeno se descreve como um velho que sente ilusões de juventude, ao passo que, durante a assinatura do contrato no texto Un contratto, cogita estar sofrendo de envelhecimento precoce (2004, p. 1101). No tocante ao último relato, são registrados dois eventos que se tornaram costumeiros, mas não sabemos há quanto tempo ocorrem; um deles, o cantor ébrio, já dura, no mínimo, algumas semanas, pois somos informados de que o bêbado canta sempre nos mesmos dois dias da semana.

Dado que identificamos os relatos apresentados pelo texto Prefazione, retomemos mais uma vez as nossas análises referentes à recaída de Zeno e às três características que destacamos a respeito da elaboração das articulações temporais do texto Le confessioni del vegliardo. Quanto à recaída, os únicos acontecimentos anteriores a esse evento ocorrem na juventude de Zeno, de modo que também são anteriores às suas curas parciais.

No tocante à análise que mencionamos sobre as três características, comecemos pela rejeição da temporalidade linear em favor da temporalidade de onda. Mesmo se tratando de um prefácio, os relatos que o integram poderiam se aproximar de uma linearidade temporal; por exemplo, poderiam contar um gradual retorno à escrita. Não encontramos nada semelhante no texto em questão, no qual as narrativas tratam de diferentes aspectos da escrita e da velhice de Zeno sem serem submetidas a um esforço de articulação.

Abordemos outra das três características, a desvalorização da sucessão temporal. Com base na cronologia aproximada que elaboramos, podemos assinalar que sequer há indícios suficientes para conseguirmos ordenar cronologicamente os três primeiros relatos, pois não sabemos precisar quando ocorreu a conversa com Carlo nem conseguimos determinar se o episódio que exemplifica a questão da medição do presente ocorreu antes ou depois do episódio inicial. Além disso, esses relatos antecedem o trecho sobre o livrinho de anotações do seu pai, o qual trata de um evento muito mais antigo do que os anteriores.

Por fim, a terceira das características em análise é a situação final da história ser tal que Zeno parece incapaz de revertê-la ainda que deseje fazê-lo. Propomos que essa característica como tal não está presente no texto Prefazione mas que essa incapacidade é colocada como a situação inicial desse texto. De fato, o episódio da moça que o protagonista confunde com a filha do velho Dondi justamente retoma o 
impasse sexual com o qual termina o texto Il mio ozio, cujo final inclusive referencia esse episódio (2004, p. 1220-1221), conforme examinamos no fim do segundo capítulo do presente trabalho. Além disso, a retirada do violino do estúdio de Zeno também marca a sua incapacidade de reverter uma situação contrária ao seu desejo, o qual, nesse caso, seria de voltar a tocar o instrumento. Não estamos nas condições mais favoráveis para desenvolver tais considerações, pois necessitamos recorrer ao retorno de Zeno à escrita, do qual trataremos na próxima seção.

Uma vez que completamos a investigação das determinações temporais que cada texto das "continuações" fornece para a história e a narração e das articulações temporais de cada um desses textos segundo a história e a sua relação com a narrativa, sintetizemos os resultados obtidos, os quais abarcam os trechos entre o fim da guerra e a recaída do protagonista, as temporalidades linear e de onda, a sucessão temporal e a incapacidade de Zeno para reverter uma situação inibidora das suas repetições do recalcado.

Quanto aos trechos entre o fim da guerra e a recaída de Zeno, recordemos que se trata de uma verificação necessária para uma análise que fizemos no final da seção anterior: para que ela seja válida, tais trechos devem ser pouco numerosos. O texto $U n$ contratto não é necessário para essa verificação, pois já o havíamos analisado na própria seção anterior. Dentre as demais "continuações", encontramos os trechos em questão apenas no texto Le confessioni del vegliardo. Desconsiderando a narrativa sobre a condução dos negócios herdados do pai, pois trata do mesmo assunto do texto $U n$ contratto, encontramos cinco trechos no referido período: o retorno de Alfio para casa graças ao fim do conflito, o envolvimento de Alfio com o comunismo, o breve relacionamento de Antonia com Eugenio, a posição contrária de Antonia à liberação dos costumes femininos depois da guerra e, apenas parcialmente, o noivado e o casamento de Antonia com Valentino antes que o genro fosse fatalmente acometido pelo envelhecimento precoce.

Além de os trechos que enumeramos serem pouco numerosos, conforme necessário à análise que fizemos na seção anterior, pudemos argumentar que o protagonista não retoma repetições do recalcado com relevância prática antes da recaída: nos três primeiros trechos, sequer encontramos indícios de tais repetições devidas ao protagonista, mesmo irrelevantes sob uma perspectiva prática; e, nos demais trechos, mesmo quando consideramos que se possa entender que o protagonista opere segundo uma repetição edipiana, avaliamos que ela não possui importância prática. 
No tocante às temporalidades linear e de onda e à sucessão temporal, propomos que há duas configurações principais, a do texto Un contratto e a dos demais textos. A primeira é a da progressividade narrativa que domina a perda gradual que Zeno sofre do controle dos negócios herdados para o filho de Olivi e que, a partir do contrato proposto pelo administrador, é diluída por sequências de ações que não contribuem para o desenvolvimento dessa perda de controle até estancar na mera acumulação de eventos posteriores ao dia da assinatura do contrato.

Em contraste com a progressividade do texto Un contratto, consideramos que, nas demais "continuações", a temporalidade linear nunca se torna relevante, tal como notamos a respeito do diário de Zeno no capítulo anterior, de modo que a temporalidade de onda vigora, e até mesmo a sucessão temporal, que é preponderante em todos os demais textos autobiográficos de Zeno, é abandonada em grande medida. Em geral, o que encontramos nesses textos são narrativas ou partes de uma narrativa que não estão ordenadas cronologicamente nem são submetidas a um esforço de articulação, o que, na maior parte das vezes, faz com que o entendimento do enredo de cada uma delas não exija a leitura das demais.

Aliás, a autonomia de cada uma das partes em termos de entendimento de enredo também se aplica em grande medida às próprias “continuações". De fato, quanto a tal aspecto, só encontramos uma possível exceção relevante: a leitura do texto Umbertino supõe que lemos o texto Le confessioni del vegliardo na medida em que assume que conheçamos a sequência formada pela morte de Valentino, pelo luto exagerado de Antonia e pela mudança dela e do filho para a casa de Zeno.

Enfim, no que tange à incapacidade de Zeno para reverter uma situação inibidora das suas repetições do recalcado, geralmente encontramos o protagonista em tal situação no final das histórias que compõem cada uma das "continuações": o afastamento voluntário do escritório da empresa herdada pelo pai e a plena entrega do seu controle para o filho de Olivi; o desentendimento definitivo com Alfio; a derrota para o falecido Valentino, implícita no luto exagerado e interminável de Antonia, a qual se torna ainda mais ostensiva quando a filha enlutada volta a morar com os pais; as restrições sofridas pela sua liberdade com a presença constante do neto na sua casa; a reafirmação dos impasses com a filha e Umbertino devido à frustração da esperança causada pelo desejo de Bigioni de se casar com Antonia; o fim da disputa sexual com Carlo após o susto que este lhe prega num jantar; a derrota que lhe é imposta dentro da própria casa pelo motorista, que se torna amante de Renata, desejada por Zeno; e a 
inibição da principal repetição oscilatória dos cuidados com a saúde na forma do impasse sexual provocado pela educação recebida de Felicita, que simplesmente bloqueia a mínima exposição do próprio desejo à mulher pela qual se sente atraído. Consideramos que apenas o texto Prefazione não adota exatamente esse modelo, pois o impasse sexual que resultou da relação com Felicita já está presente na situação inicial do protagonista no relato de abertura desse texto. De qualquer modo, a inibição das repetições do recalcado é um resultado consistente no desenvolvimento do protagonista em todas as "continuações", de modo que essa mudança é a segunda das tranformações da compulsão repetitiva de Zeno nesses textos.

A investigação da constituição de Zeno como escritor das "continuações", à qual nos dedicaremos na próxima seção, permitirá que desenvolvamos a análise tanto das duas configurações principais das "continuações" no que se refere às temporalidades linear e de onda e à sucessão temporal quanto das recorrentes situações de inibição das repetições do recalcado do protagonista.

\subsection{A constituição de Zeno como escritor das "continuações"}

Dedicaremos a presente seção ao estudo da constituição de Zeno como escritor das "continuações". Para isso, exploraremos a caracterização que Zeno faz de si mesmo ao escrever como um velho consumado e os episódios nos quais o protagonista experimenta algum tipo de reaproximação da juventude; estudaremos a relação da velhice com a temporalidade da nota única que resulta das inibições das repetições do recalcado às quais o protagonista termina submetido; e argumentaremos que o retorno de Zeno à escrita autobiográfica é a sua reação à velhice na medida em que lhe serve de instrumento para retomar as repetições que lhe são negadas na condição de protagonista, de modo que esse retorno produz a última das três tranformações da compulsão repetitiva de Zeno nas "continuações".

Comecemos a considerar o retorno de Zeno à escrita na nossa investigação das "continuações" por uma característica destacada por ele próprio e que diferencia o escritor do protagonista. Estamos nos referindo à velhice de Zeno, que está completamente instalada no caso do escritor, mas não iniciou ou ainda está se 
consolidando no caso do protagonista. Essa diferença está nitidamente assinalada no texto Il mio ozio: "Io non ero ancora ben vecchio. È una storia di tre anni fa e contavo dunque 67 anni: Non ero ancora un vegliardo" (2004, p. 1202-1203). Alguns trechos registram explicitamente esse processo de transformação. $\mathrm{O}$ mais antigo deles, no texto Un contratto, ainda se refere a um envelhecimento precoce como hipótese para que o protagonista não seja mais capaz de conduzir os próprios negócios: "Le confessai [a Augusta] ch'era vero ch'io più non sapevo lavorare. Era forse l'età? Non avevo allora che 63 anni ma poteva trattarsi di un invecchiamento precoce" (2004, p. 1101). Outro dos trechos em questão está no texto Il mio ozio, no qual Zeno afirma que Felicita o educou para a carreira de velho: "Alla carriera di vegliardo cui sono ora condannato, io fui educato da Felicita. Io appena ora so che in amore io non valgo altro che per quello che pago. E la mia bruttezza m'è sempre presente" (2004, p. 1220).

Propomos que não se trata de um acaso que a primeira referência do protagonista a estar entrando na velhice apareça como uma doença, o envelhecimento precoce, pois ela justamente opera como a doença da qual Zeno pretende haver sido curado pelo comércio durante a guerra e que não voltou com a recaída do protagonista nas repetições da rivalidade edipiana. Essa aproximação direta entre a velhice e a doença também aparece no texto Il mio ozio; mais precisamente, no fato da série de cuidados com a saúde culminar na tentativa de evitar a morte devida ao envelhecimento do corpo por meio da aptidão à reprodução (2004, p. 1202). Assim, tal como a doença, Zeno considera que a velhice é passível de ser tratada terapeuticamente.

A abordagem terapêutica da velhice redunda até mesmo numa iniciativa cirúgica, a operação de rejuvenescimento, a qual está presente nos textos $I l$ mio ozio e Le confessioni del vegliardo. Quanto ao primeiro caso, trata-se do mesmo trecho que mencionamos no parágrafo anterior: a operação supostamente recuperaria a plena capacidade reprodutiva dos órgãos sexuais, mas é descartada por Zeno, que considera impossível esse resultado. No tocante ao segundo caso, Zeno se submete à cirurgia. Analisemos com cuidado como ela é abordada pelo texto, pois é relacionada com elementos importantes para o desenvolvimento da presente seção. Antes de tratar da operação, Zeno compara a sua situação presente, a da velhice, com aquela da primeira vez que se dedicou à escrita autobiográfica:

Avrò la sorpresa di trovare me che qui descrivo molto differente da colui che descrissi anni or sono. La vita, benché non descritta, lasciò qualche segno. Mi pare che col tempo un po' si rasserenò. Mi mancano quegli sciocchi rimorsi, quelle spaventose paure del futuro. Come potrei spaventarmene? È quel futuro quello ch'io vivo. Va via senza prepararne un altro. Perciò non è 
neppure un vero presente, sta fuori del tempo. Manca un tempo ultimo nella gramatica. È vero che la storia dell'operazione di ringiovanimento mi parve tanto importante. (2004, p. 1117)

Depois de relatar brevemente o período da cirurgia, Zeno trata novamente da velhice e apresenta os resultados efetivos da operação:

\begin{abstract}
Ma del resto la vecchiaia è il periodo calmo della vita. Tanto calmo ch'è difficile registrarlo. Da quale parte afferrarlo per descrivere quello che precorse all'operazione? Dopo è facile. L'aspettativa della giovinezza voluta dall'operazione fu una specie di giovinezza, qualche cosa ch'ebbe la facoltà di creare un periodo tant'è vero io so descriverlo coi suoi grandi dolori e grandi speranze. Ed io vedo ora la mia vita iniziarsi con la fanciullezza [...], e passò alla vecchiaia di cui la caratteristica principale fu di farmi entrare nell'ombra e togliermi la parte di protagonista. Per tutti, per noi pure io oramai vivevo perché gli altri, mia moglie, mia figlia, mio figlio e mio nipote avvessero maggiore rilievo. Poi venne l'operazione e tutti mi guardarono con ammirazione. Io m'agitai, ritornai a qualche tratto di vita, molto simile a quelli ch'erano i miei proprii, voglio dire quelli di quella vita che non aveva avuto bisogno di operazioni [...]. (2004, p. 1117-1118)
\end{abstract}

O narrador caracteriza a velhice de três maneiras. As duas primeiras são como um tempo sem futuro e um período mais sereno e mais calmo do que os anteriores. Ora, tais caracterizações são compatíveis com a temporalidade da nota única, tal como a apresentamos na última seção do segundo capítulo. A terceira maneira é a perda de protagonismo, o qual é assumido por parentes. Antes mesmo de ser realizada, a operação de rejuvenescimento reverteu as três características da velhice que foram apresentadas por Zeno: a própria expectativa da juventude já lhe deu um futuro, e ele volta a ser protagonista na medida em que todos o admiram por causa da operação, o que também lhe devolve a agitação, da qual estava afastado pela calmaria senil. O único detalhe é que a cirurgia fracassa, de modo que a reversão está sujeita a ser anulada. De qualquer maneira, a operação sugere que a velhice poderia ser superada por algum modo de reaproximação da juventude.

Antes de avançarmos na investigação sobre a reaproximação da juventude por Zeno, retomemos a temporalidade da nota única nas "continuações". Além das duas citações que analisamos no parágrafo anterior, já expusemos na última seção do segundo capítulo como Zeno remete a essa temporalidade nos textos Un contratto, Il mio ozio e Prefazione: no primeiro caso, propomos que ela provinha da interrupção do exercício da rivalidade com o filho de Olivi devido à assinatura do contrato que este impôs ao protagonista; nos dois casos restantes, argumentamos que ela resultava do impasse sexual que conclui a relação com Felicita. Logo, nessas três "continuações", a temporalidade da nota única está vinculada com o protagonista por aquelas inibições das 
repetições do recalcado que estudamos na seção anterior. Além disso, no caso do texto Il mio ozio, a nossa argumentação já considerava também o narrador. Uma vez que as nossas considerações sobre esse texto já tratam tanto do vínculo das inibições das repetições do recalcado quanto do narrador, abordemos a temporalidade da nota única nas demais "continuações" segundo esses dois aspectos.

No tocante ao texto Un contratto, encontramos o narrador submetido à temporalidade da nota única já na sentença de abertura: "Non ho mai capito bene come io sia arrivato alla mia inerzia attuale, io che durante la guerra ero considerato in città come un uomo molto operoso" (2004, p. 1089). Essa inércia do narrador, tal como o tédio do protagonista, está vinculada ao afastamento permanente dos próprios negócios devido ao contrato proposto pelo filho de Olivi, pois o único dano duradouro que o narrador assinala explicitamente é uma doença causada pelo contrato: "E quel sentimento di essere una povera vittima innocente, che doveva accompagnarmi per tanto tempo e degenerare in malattia, nacque proprio lì, al momento di subire la lettura di quel contratto" (2004, p. 1109). Observemos que podemos considerar que a qualificação de pobre vítima se justifica exatamente porque Zeno não é mais capaz de exercer a rivalidade com o filho de Olivi.

Quanto ao texto Le confessioni del vegliardo, só precisamos examinar a relação da temporalidade da nota única com as inibições das repetições do recalcado do protagonista, pois já tratamos de como o narrador também está submetido a essa temporalidade. Ora, ao tratarmos do narrador, comentamos que uma das características que ele atribui à velhice é a perda de protagonismo para alguns parentes. Dentre eles, Zeno inclui o filho e a filha, aos quais justamente são dedicadas as duas principais narrativas do texto em análise. Pois bem, o desfecho dessas narrativas é contundente em recusar a Zeno qualquer protagonismo na relação com os filhos. No caso de Alfio, verificamos que o protagonista se encontra num impasse que o impede de se reconciliar com o filho, de modo que este descarta sumariamente todas as tentativas do pai de iniciar uma conversa. No caso de Antonia, Zeno precisaria encerrar o luto exagerado que ela dedica a Valentino, mas já comentamos que ele é incapaz de fazê-la abandonar o luto.

Também podemos ratificar a nossa proposta do parágrafo anterior examinando uma das principais considerações do narrador sobre os filhos no texto em análise, a reação que terão quando ele morrer. Ele aborda essa reação duas vezes. Eis a primeira delas: "Essa [Antonia] potrà vedermi morire con piena serenità $[\ldots]$. E verrà anche lieta 
a portare sulla mia tomba dei fiori [...]. Io so che [Alfio] non fa una grande stima di me. Per lui, artista, un buon commerciante è un bestione di cui non va tenuto conto" (2004, p. 1125). O narrador confirma esse parecer sobre a reação à sua morte muitas páginas depois: “Augusta m'avrebbe pianto in pieno equilibrio, Antonia non avrebbe pianto affatto e Alfio avrebbe potuto fare come avevo fatto io o tutt'altrimenti che sarebbe stato lo stesso per me" (2004, p. 1146). Em suma, o narrador gostaria que a sua morte fosse chorada conforme cogita que Augusta faria, mas teme que o filho desejaria o transpasse paterno tal como o próprio Zeno desejou o do próprio pai e que a filha simplesmente não choraria por ele, o que representaria uma enorme derrota em favor de Valentino, dado que Zeno já presenciou durante meses o intenso e aparentemente interminável pranto que Antonia dedica ao falecido esposo.

Assim, propomos que o protagonismo reclamado pelo narrador equivale à capacidade de exercer as suas repetições do recalcado, as quais estão inibidas pela situações finais das suas relações com o filho e a filha. Ademais, na medida em que consideramos a falta de protagonismo como a incapacidade de tal exercício, ela é intrínseca à temporalidade da nota única e, portanto é válida para todas as "continuações".

No tocante ao texto Umbertino, não encontramos nenhuma indicação de que o narrador opere segundo a temporalidade da nota única; tampouco encontramos alguma indicação do contrário. Apesar disso, devemos observar que os elementos que associamos a essa temporalidade estão presentes e relacionados da maneira que já expusemos. De fato, o narrador inicia esse texto tratando da velhice, em geral e a própria, e, com base na mudança de os jovens se tornarem respeitados em substituição aos velhos, elabora a seguinte conclusão: "Ora che sono vecchio non si rispettano che i giovani, così che io sono passato per la vita senza essere stato rispettato mai" (2004, p. 1158). Logo, o narrador protesta contra a falta de respeito com a qual os jovens tratam um velho como ele. Ora, consideramos que esse modo de caracterizar a velhice justamente está ligado às situações de inibição das repetições do recalcado de Zeno no sentido de que elas se baseiam nos maiores desrespeitos sentidos por ele no que se refere a cada um dos personagens: Umbertino costuma lhe restringir a liberdade na sua própria casa; Antonia e Renata lhe obrigam a conviver com a predileção delas pelo marido morto e por Fortunato, também dentro da casa de Zeno; e Carlo termina a disputa sexual entre eles lhe pregando um susto ao simular que estava denunciando as traições conjugais do tio. Tal como a falta de protagonismo no texto Le confessioni del 
vegliardo, o desrespeito dos jovens também é válido para outras "continuações"; na verdade, apenas no caso do texto Prefazione não seríamos capazes de justificar uma reclamação semelhante de Zeno.

Ainda precisamos tratar do texto Prefazione para terminar a nossa abordagem da temporalidade da nota única, mas esse caso já envolve outras questões, de modo que usaremos esse texto para retomarmos a nossa investigação sobre a reaproximação da juventude por Zeno e terminaremos a mencionada abordagem durante essa investigação.

O episódio de abertura do texto Prefazione oferece um modo de reaproximação da juventude que é bem mais acessível do que a operação de rejuvenescimento. O ponto de partida é a tentativa de Zeno de não ser mais uma vez dominado pelo impasse no qual se encontra o seu desejo sexual desde o fim da relação com Felicita, conforme podemos depreender da sua reação dentro do carro com Augusta após avistar a jovenzinha que passa entre os veículos na praça Goldoni: "E allora [...] sentii che sarebbe stato crudele che l'attimo fosse fuggito senza creare alcuna relazione fra me e quella giovinetta. Troppo crudele. [...] Ricordai! C'era già tale relazione fra me e lei. Io la conoscevo. La salutai [...] e accompagnai il mio saluto di un sorriso" (2004, p. 1223). Eis como o próprio Zeno comenta essa saudação no final do texto Il mio ozio: "Io la salutai per farle qualche cosa e sentire meglio la sua bellezza. È il destino dei vecchi di fare dei bei saluti” (2004, p. 1221). Logo, é graças à recordação que o protagonista pode expressar muito brevemente a sua admiração pela moça e, portanto, obter uma rara dose satisfatória de exercício do seu desejo sexual.

É crucial que entendamos que não se trata de uma recordação tão simples quanto o protagonista achou inicialmente. De fato, ele recordou a filha do velho Dondi, que é tão velha quanto o próprio Zeno, e uma situação em especial com ela:

\footnotetext{
E vi si accompagnò anche il ricordo di parole con le quali la giovinetta aveva fatto ridere tutti i molti presenti: - Perché da un tetto non cade mai un gatto solo ma sempre due? - Così essa allora aveva gettato in faccia a tuti la sua sfacciata innocenza come ora in piazza Goldoni. Ed allora ero stato tanto innocente anch'io da ridere con tutti gli altri invece che prenderla fra le mie braccia tanto bella e tanto desiderabile. Voglio dire che tale ricordo mi ringiovanì per un istante e ricordai di essere stato capace di afferrare, di tenere, di lottare.

Augusta fece cessare tale sogno sconvolto con uno scoppio di riso: - La figlia del vecchio Dondi a quest'ora ha la tua età. (2004, p. 1223-1224)
}

Assim, a pessoa recordada não é a jovenzinha saudada pelo protagonista, mas a situação presenciada por ele e a sua reação a ela são recordações que correspondem ao que ocorreu na praça Goldoni. Em ambos os casos, uma moça que está exposta 
publicamente - uma pela inocência do que diz e outra pelo perigo que corre entre os carros - desperta o desejo sexual de Zeno, o qual ganha uma expressão compatível com a impossibilidade de satisfazê-lo devido à natureza pública de ambas as situações, seja rindo com os demais da inocência de uma, seja saudando com admiração a moça na praça Goldoni. Com base no período final do primeiro parágrafo da citação, consideramos que essa recordação que Zeno tem da sua juventude efetivamente o faz rejuvenescer porque também permite que aja como agia quando era jovem no sentido de que supera pontualmente algum dos impasses aos quais está submetido na sua velhice e, na medida em que consegue esse êxito, lhe sugere que o impasse talvez não seja definitivo, de modo que Zeno poderia voltar ao pleno exercício da sua compulsão à repetição, tal como ocorria no tempo recordado.

No segundo parágrafo da citação, Augusta elimina a confusão temporal de Zeno e faz referência à sua idade, de modo que rompe a sua experiência de rejuvenescimento e o protagonista se torna sensível a esse afastamento ou perda da juventude, especialmente no caso da filha do velho Dondi na medida em que saiu de Trieste após casar com um estrangeiro: "Ed io perciò ora rividi la povera Dondi [...] moversi in qualche cantuccio della terra, sconosciuta, cioè fra gente che mai l'aveva vista giovine. Me ne commossi perché era il mio stesso destino benché io mai mi fossi allontanato da qui" (2004, p. 1224). Da perspectiva de quem teve uma experiência de rejuvenescimento graças à recordação, a ausência de convivência com quem o conheceu durante a juventude significa que as outras pessoas não podem lhe fornecer recordações que o ajudem a recuperar a própria juventude. Consideramos que o protagonista se sente nessa situação porque, devido à compulsão à repetição do recalcado, uma parte crucial da sua subjetividade geralmente permanece no desconhecimento, inclusive no que tange a ele próprio. É nesse sentido que entendemos o trecho sobre o conhecimento insuficente de Augusta e de Zeno no que se refere a essa fase etária do protagonista: "Eppoi essa conobbe la mia giovinezza solo in parte, voglio dire molto superficialmente. Io stesso ricordo meglio le avventure della mia giovinezza che l'aspetto e il sentimento suo" (2004, p. 1225). Logo, esse conhecimento superficial exige de Zeno um esforço para obter as recordações que lhe proporcionem o rejuvenescimento desejado. Ademais, trata-se de um esforço solitário, pois as outras pessoas são incapazes de ajudá-lo nessa tarefa.

Em suma, consideramos que o episódio de abertura do texto Prefazione expõe como a reaproximação da juventude que Zeno deseja pode ser obtida pela recordação e 
assinala a dificuldade referente à insuficiência das recordações de que ele dispõe, sejam as suas ou de outros.

Tal como no texto Le confessioni del vegliardo, Zeno experimenta um rejuvenescimento que temporariamente o retira da inibição das suas repetições do recalcado, ainda que a causa da experiência não seja igual nos dois casos. Apesar da experiência em si ser passageira, terminando com o fracasso da cirurgia de rejuvenescimento num caso e com o riso de Augusta diante do erro na recordação do marido no outro, o resultado final que ela provoca é duradouro e é igual em ambos os casos. Comecemos pelo resultado da agitação que a decisão de fazer cirurgia reintroduziu na vida de Zeno: “e l'agitazione finì col portrarmi a questa carta che mi pare non avrei mai dovuto abbandonare. [...] Io ora scrivo perché devo mentre prima la penna in mano m'avrebbe fatto sbadigliare. Perciò io penso che l'operazione abbia pur avuto un effetto salutare" (2004, p. 1118). Logo, tal resultado é a retomada da escrita autobiográfica. A nossa proposta é que, desta vez, a escrita opera como um instrumento de reaproximação consistente da juventude, de modo que Zeno se mantenha vinculado a ela, o que estaria expresso na citação pela associação com a agitação provocada pelo rejuvenescimento temporário antes da cirurgia. Nesse sentido, o comentário de que anteriormente escrever faria Zeno bocejar justamente assinalaria que ele não teria nenhum propósito para essa ação. Além disso, a superação do bocejo também poderia aludir ao fim da temporalidade da nota única por meio da escrita. Em termos da repetição do recalcado, esse afastamento parcial da velhice exige algum grau de superação da inibição dessa repetição, o que torna bastante irônico o efeito salutar do rejuvenescimento que afinal a operação indiretamente produziu.

Retornando ao texto Prefazione, o resultado final da experiência de rejuvenescimento também é a dedicação à escrita autobiográfica como um instrumento de reaproximação consistente da juventude. Nesse caso, a operação de reaproximação é um pouco mais clara, pois Zeno parece supor que a atenção constantemente orientada para o passado que a escrita das recordações exige seria favorável ao seu propósito de reconhecer traços da sua juventude nos acontecimentos recordados. É o que nos sugerem os comentários de Zeno sobre a tarefa de narrar a própria vida:

Chissà come nel presente guardato attentamente ritroverò qualche tratto della mia giovinezza che le mie gambe stanche non mi permettono d'inseguire e che cerco di evocare perché venga a me. Già nelle poche righe che stesi la intravvidi, m'invase in modo da arrivare a diminuire nelle mie vene la stanchezza della mia età. (2004, p. 1228) 
Assim, em vez de pretender que o corpo seja capaz de atos próprios aos jovens, como seria o caso de uma operação exitosa de rejuvenescimento, Zeno se serve da escrita a fim de tentar evocar traços da sua juventude, como se a trouxesse até o seu corpo velho, para ser revigorado por ela. Ressaltemos apenas que a nossa proposta é de que a evocação de traços juvenis se refere à retomada do exercício das repetições edipianas que estão inibidas para o narrador, de modo que a recordação pode apenas fornecer a oportunidade para que o narrador exerça uma repetição que nem ocorreu no momento recordado, o que retomaremos na próxima seção.

Além de a experiência de rejuvenescimento resultar na dedicação à escrita autobiográfica, outro elemento do processo em análise que é comum aos textos $L e$ confessioni del vegliardo e Prefazione é o modo pelo qual esse resultado é obtido. No primeiro texto, Zeno só se dedica a escrever como resultado da agitação causada pela cirurgia de rejuvenescimento após reler o que escrevera em razão do tratamento com o doutor S.: "Di questi giorni scopersi [...] la sola cosa importante che mi sia avvenuta: La descrizione da me fatta di una sua parte. Certe descrizioni accatastate messe in disparte per un medico che le prescrisse. La leggo e rileggo [...]" (2004, p. 1116). A releitura dos manuscritos da época da terapia psicanalítica é igualmente importante no segundo texto. De fato, Zeno se sentiu rejuvenescido ao saudar a jovenzinha que ele confunde com a filha do velho Dondi, mas foi interrompido pelo riso de Augusta e só consegue retomar o rejuvenescimento com essa releitura, a qual é aproximada ainda mais do tempo da narração: "Ieri le rilessi" (2004, p. 1227). Em suma, entendemos que ambos os casos mencionados sugerem que a releitura em questão fornece a Zeno o modelo da escrita autobiográfica como instrumento pelo qual o narrador volta a ser capaz de exercer as repetições do recalcado.

Consideramos que a nossa argumentação sobre a escrita autobiográfica no texto Prefazione pode ser confirmada por meio do episódio do bêbado cantor (2004, p. 1232-1233) na medida em que os principais elementos dessa argumentação estão sintetizados no episódio, no qual Zeno projeta a sua atividade de escritor sobre a cantoria do bêbado no sentido de que, ainda que nunca haja falado com ele e tenha poucas informações a seu respeito, cogita que o ébrio solitário busque o passado por meio da antiga história da única canção à qual se dedica porque crê estar velho, apesar de ter menos do que quarenta anos, devido a ter um filho de vinte anos, o que obviamente remete à relação de Zeno com Alfio. Analisaremos outros aspectos desse episódio na seção final do presente capítulo. 
Por fim, estamos em condição de completar a nossa investigação sobre a temporalidade da nota única, a qual está mais diretamente associada à questão da escrita no texto Prefazione:

\begin{abstract}
Devo pensare e scrivere per sentirmi vivo perché la vita che faccio fra tanta virtù che ho e che mi viene attribuita e tanti affetti e doveri che mi legano e paralizzano mi priva di ogni libertà. Io vivo con la stessa inerzia con cui si muore. E voglio scuotermi, destarmi. [...] sarà virtù veramente mia e non esattamente quella predicata dagli altri che quando l'ho indossata m'opprime invece di vestirmi. O smetterò cotesto vestito o lo saprò foggiare per il mio dosso.

Perciò lo scrivere sarà per me una misura d'igiene cui attenderò ogni sera poco prima di prendere il purgante. E spero che le mie carte conterranno anche le parole che usualmente non dico, perché solo allora la cura sarà riuscita. (2004, p. 1226-1227)
\end{abstract}

A inércia de um morto remete à temporalidade da nota única segundo a qual opera o narrador e é associada à privação de toda a liberdade devido ao resultado da sua interação com outras pessoas. Consideramos que essa seja mais uma formulação do vínculo entre a temporalidade da nota única e a incapacidade de exercer as repetições do recalcado. Essa formulação é bastante geral, de modo que abarca antes o conjunto das situações de bloqueio dessas repetições do que algumas delas em particular. Além disso, propomos que a citação destaca um aspecto específico da superação da temporalidade da nota única: ao manifestar o desejo de despertar a si próprio a fim de sair da inércia na qual se encontra, Zeno não só conclui que as virtudes que lhe são predicadas pelos outros serão adaptadas para efetivamente lhe servirem ou serão substituídas pelas virtudes que são verdadeiramente suas, mas também declara que esse é o motivo pelo qual a escrita terá uma função higiênica, a qual aproxima do purgante que ingere todas as noites. Parece-nos que essa aproximação é uma sugestão de que a escrita permite a Zeno o exercício das repetições do recalcado, ainda que num âmbito de privacidade, em contraste com a inibição na qual elas se encontram na convivência intersubjetiva.

O parágrafo sobre a função higiênica e o purgante ressoa aspectos mencionados no texto Le confessioni del vegliardo. Quanto à menção à higiene, já comentamos que, nesse texto, a escrita é tratada como um efeito salutar da operação de rejuvenescimento. Observemos que a saúde que Zeno julga ser proporcionada pela escrita corresponde ao modo como trata a própria velhice como uma doença, conforme já comentamos nos primeiros parágrafos da presente seção: a suspeita de sofrer de envelhecimento precoce, a tentativa de evitar a morte devida ao envelhecimento do corpo como parte da série de cuidados com a saúde e a própria tentativa de rejuvenescer por meio de uma cirurgia. 
No tocante ao efeito purgativo da escrita, consideramos que a seguinte citação do texto Le confessioni del vegliardo opera um contraste equivalente entre os resmungos inócuos de Zeno em casa e aqueles que pretende registrar nos seus manuscritos:

\footnotetext{
In casa mi danno del brontolone. Li sorprenderò. Non aprirò più la bocca e brontolerò su questa carta. Io non sono fatto per la lotta e quando mi fanno intendere che non capisco più bene le cose invece che negare e cercar di provare che sono ancora capace di dirigere me stesso e la mia famiglia correrò qui a rasserenarmi. $(2004$, p. 1117$)$
}

Atribuimos tais contrastes entre determinado aspecto da relação com as pessoas e o efeito do mesmo aspecto durante a escrita às restrições que a rivalidade velada ou os conflitos entre as repetições impõem a Zeno na relação direta com as pessoas, pois essas restrições geralmente não operam quando ele escreve sobre a sua relação com as mesmas pessoas.

Em suma, investigamos na presente seção como Zeno é constituído como escritor das "continuações" de modo a se afastar da doença da velhice, a qual consiste em estar submetido à temporalidade da nota única, na medida em que o torna capaz de retomar as suas repetições do recalcado durante a atividade da escrita. Desenvolveremos as consequências desse resultado para os tempos da narrativa e da narração na próxima seção.

\subsection{As consequências da constituição de Zeno como escritor: a construção da narrativa nas "continuações" com base na retomada das repetições do recalcado}

Dedicaremos esta seção à investigação da construção da narrativa nas "continuações" segundo uma condição que propomos com base na constituição de Zeno como narrador: os tempos da narrativa e da narração devem satisfazer a condição de que, durante a atividade narrativa, Zeno retome as repetições do recalcado que estão inibidas no final do tempo da história. Consideramos que há dois modos de atender essa condição, os quais estudaremos ao longo da presente seção.

Para tratarmos do primeiro modo de satisfazer a condição que formulamos para os tempos da narrativa e da narração, recorramos ao episódio no qual o protagonista e Carlo narram as suas aventuras sexuais de um para o outro no texto Umbertino (2004, p. 
1186-1188). Já comentamos que o simples relato para Carlo proporciona ao protagonista a oportunidade de repetir a competição sexual com um rival, de modo que as histórias relatadas nem precisam ser verdadeiras. Também já comentamos que essa repetição é inibida devido ao susto que o sobrinho lhe prega ao insinuar a Augusta que o seu marido não lhe era fiel. Ora, Zeno está sujeito a essa inibição como protagonista, mas consegue uma alternativa a ela e retoma a repetição inibida na condição de narrador dedicado à escrita autobiográfica.

Além de repetir a rivalidade edipiana da competição sexual com Carlo pelo mero relato do episódio em análise, o narrador não corre o risco de que o texto que escreveu denuncie as traições relatadas, de modo que a própria narração implicitamente responde à pergunta que encerra o episódio: "Perché abbandonarmi ora per amore di una stupida chiacchiera ora che non correvo altri pericoli?" (2004, p. 1188). Apresentemos outra vantagem que o narrador possui sobre o protagonista: ao contar a história, ele não precisa se preocupar que outras pessoas percebam as suas hostilidades, de modo que pode expressá-las sem causar um conflito com a rivalidade velada que é própria da compulsão patológica de Zeno, o que é outra repetição edipiana na medida em que engana o rival. Assim, ele pode declarar expressamente que mentia para Carlo exagerando as aventuras sexuais que lhe contava.

Por meio da análise que fizemos do episódio da competição sexual com Carlo, verificamos que Zeno é capaz de retomar as repetições inibidas no tempo da narração apenas relatando episódios nos quais o protagonista ainda as exercia. Esse é o modo mais simples de Zeno realizar essa retomada por meio da narrativa, já que o narrador repete da mesma maneira que o protagonista e, portanto, sem necessidade de introduzir elementos estranhos ao momento relatado da história. À repetição edipiana promovida pelo próprio relato, obrigatória no modo em análise, o narrador pode acrescentar outras ocorrências da mesma repetição que sejam específicas do tempo da narração.

A seleção de quais momentos da história compõem a narrativa justamente privilegia o exercício pelo protagonista das repetições que lhe serão inibidas e, portanto, a retomada das repetições inibidas pela mera narração é o modo mais comum de satisfazer a condição que formulamos no caso da atividade narrativa. De forma geral, pertencem a esse modo todas as recorrências edipianas do protagonista nas "continuações" que estudamos no segundo capítulo. Como o narrador repete-as da mesma maneira que o protagonista, acrescentando ou não ocorrências específicas ao tempo da narração, não há razão para que voltemos a nos ocupar delas. Ressaltemos 
apenas que o narrador expressa tranquilamente as hostilidades contra os rivais ao passo que o personagem as tratava de maneira evasiva devido à rivalidade velada. Além das mentiras do episódio da competição sexual com Carlo, ofereçamos também o exemplo das duas mentiras ditas a Valentino para afastá-lo da negociação com o filho de Olivi no texto Un contratto (2004, p. 1102-1106).

O segundo modo de os tempos da narrativa e da narração satisfazerem a condição de que o narrador retome as repetições do recalcado que estão inibidas no final do tempo da história é pelo exercício por parte do narrador de recorrências edipianas que o protagonista não exercia no momento que está sendo relatado ou exerceu apenas de forma parcial ou insuficiente, de modo que somente a repetição do narrador é satisfatória.

Antes de investigarmos os casos mais gerais, nos quais o narrador não se limita apenas à atividade narrativa, tratemos da situação pouco comum que é basicamente um híbrido dos dois modos de o narrador retomar as repetições inibidas no sentido de que o mero relato é suficiente para que ele exerça uma repetição edipiana que não havia para o protagonista. Consideremos dois casos nos quais isso ocorre: quando Zeno narra hostilidades contra algum rival antes da recaída na compulsão edipiana ou quando a própria narração opera como uma rivalidade edipiana apesar de o episódio relatado ser desprovido de ações hostis. Finalmente, observemos que é especialmente importante para a situação em análise que, conforme comentamos há pouco, nem narrar as hostilidades contra os rivais nem mesmo hostilizá-los por meio da narração entra em conflito com a rivalidade velada, à qual o narrador está submetido.

No caso da narração sobre hostilidades anteriores à recaída na compulsão edipiana, trata-se, para o protagonista, apenas do exercício trivial da rivalidade declarada, ao passo que o narrador pratica uma repetição edipiana ao declarar como hostilizava o adversário. A principal ocorrência dessa situação são as disputas com o filho de Olivi antes de Zeno começar a se entediar no escritório no texto Un contratto (2004, p. 1091-1094). Esse conflito aberto entre ambos sobre questões da época da guerra não está relacionado com a condução dos negócios herdados por Zeno, de modo que esse trecho poderia ser suprimido sem afetar o resto do texto, o qual trata, direta ou indiretamente, da condução desses negócios; entretanto, a inclusão desse trecho fornece ao narrador a principal repetição edipiana contra o filho de Olivi que acrescenta ao que está relatando, a qual se torna ainda mais relevante por ser a única na qual o protagonista consegue vencer esse rival de grande importância. 
Como exemplo para o caso de a própria narração ser uma repetição edipiana apesar de o episódio relatado ser desprovido de ações hostis, ofereçamos o episódio no qual o protagonista sente admiração pela pintura comprada de Alfio no texto Le confessioni del vegliardo (2004, p. 1132-1134). De fato, o protagonista se restringe à descoberta desse sentimento, ao passo que o narrador se dedica a declarar essa admiração ao longo de mais de uma página para finalmente deixar registrado a sua opinião sobre a pintura e, portanto, confrontar a opinião que o próprio Alfio tinha sobre ela, ou seja, trata-se de uma resposta de Zeno para a recusa nada generosa do filho ao modo pelo qual o pai aprecia o quadro e para as vezes que falou sobre a pintura usando as palavras de Alfio em detrimento do que ele próprio pensava sobre ela (2004, p. 1134).

Uma vez que tratamos da repetição edipiana que o narrador acrescenta mesmo se restringindo ao mero relato, investiguemos, em cada uma das "continuações", o caso generalizado das repetições do recalcado que o narrador acrescenta à narrativa extrapolando a atividade de contar o que ocorreu ao protagonista num determinado momento, o que pode ser feito tanto pela introdução de elementos estranhos ao protagonista, mesmo que ela seja tão implícita quanto recorrer a outro momento da história relatada, quanto pela descrição de um personagem, na medida em que ela permite declarações que são repetições edipianas cujo exercício era limitado para o protagonista.

Começando a nossa investigação pelo texto Un contratto, a principal repetição inibida que o narrador retoma nesse texto ao extrapolar a mera atividade narrativa é a competição sexual pela filha enlutada por meio da rivalidade contra o genro, da qual o elemento mais insistente é a declaração sobre a sua morte. Ora, conforme estabelecemos na segunda seção, a história narrada antes dos episódios ulteriores ao dia da assinatura do novo contrato é anterior a 1921, ou seja, muito antes do falecimento de Valentino. Assim, na primeira referência ao genro no texto, Zeno faz questão de mencionar que está morto: "Quella bestia di mio genero (poverino mi dispiace di dirlo così ora, ora ch'è morto non vorrei fargli di torto) [...]" (2004, p. 1095). Ademais, a rivalidade contra Valentino também é sugerida quando vincula o desejo de não lhe fazer mal ao fato de que ele não vive mais. Encontramos outra dessas referências duas páginas adiante: "Che il povero morto [...]” (2004, p. 1097). O segundo encontro com genro também traz uma dessas referências: "Più tardi - quando morì - compresi e scusai. [...] non sapeva abbandonare un affare che quando l'aveva compreso a fondo ciò che domandava uno 
spazio di tempo non tanto piccolo perché egli pensava lentamente e con grande esattezza" (2004, p. 1103). Aproveitemos para observar que a prolepse narrativa também dá a oportunidade para que Zeno mencione o pensamento lento e excessivamente detalhado que atribui a Valentino.

Além dos episódios dos quais o genro participa durante a negociação do novo contrato, a sua morte é referida em mais dois trechos. O primeiro deles é o trecho no qual o protagonista evoca o envelhecimento precoce como uma possível causa para não saber mais conduzir os próprios negócios: "Noto come uma coincidenza curiosa ch'era la prima volta che in casa si evocava quella malattia. E quando essa colse Valentino ebbi per un momento un rimorso come se gliel'avessi appioppata io" (2004, p. 1101). Logo, o narrador usa uma repetição edipiana que o protagonista só terá ulteriormente a fim de exercer mais uma vez essa repetição já na primeira menção do protagonista a essa doença. O segundo dos trechos mencionados resulta da afirmação do filho de Olivi de que Valentino não é como um filho para Zeno, a qual faz com que o narrador aborde a dúvida que teve a esse respeito, culminando com a narrativa do remorso diante do leito do genro moribundo (2004, p. 1107-1108), a última das referências à morte de Valentino que Zeno inclui num texto alegadamente dedicado à perda do controle da empresa herdada do pai.

O próximo texto que abordaremos na presente investigação é Le confessioni del vegliardo, do qual consideramos que as principais repetições inibidas que o narrador retoma extrapolando a mera atividade narrativa sejam a rivalidade edipiana contra o filho e a competição sexual com Valentino pela filha. Além disso, destacaremos uma forma recorrente dessa retomada que o narrador usa para algumas repetições inibidas no texto mencionado e no texto Umbertino: o parecer sobre os parentes segundo a associação hereditária.

Dada a recente análise que dedicamos ao genro de Zeno no texto Un contratto, comecemos tratando da retomada pela competição sexual com Valentino por Antonia. As repetições dessa retomada abrangem tanto o genro quanto a filha. No tocante a Valentino, encontramos três modos principais pelos quais o narrador interfere na narrativa de modo a retomar a rivalidade inibida contra ele. O primeiro deles é a comparação com o irmão Eugenio, do qual o texto em análise não nos dá nenhum indício de que haja sido conhecido pelo protagonista, uma vez que o namoro com Antonia transcorre durante a participação da Itália na guerra. Assim, consideramos que seja o narrador que decida comparar o desconhecido Eugenio com o irmão no seguinte 
trecho, cujo único verbo que tem Zeno por sujeito está no presente da narração: "Ma l'amore c'era stato sicuramente. Io lo so per il fatto che alla morte di Eugenio, Antonia subito accettò di fidanzarsi col fratello Valentino che ne era tanto meno amabile. [...] Povera Antonia! Di quale surrogato dovette accontentarsi!” (2004, p. 1149).

$\mathrm{O}$ segundo dos modos em análise de retomada da rivalidade inibida contra $\mathrm{o}$ genro são as menções à morte de Valentino ainda antes de ele adoecer de envelhecimento precoce, tal como comentamos sobre o texto Un contratto. A primeira delas já aparece quando o narrador começa a tratar dele após a exposição sobre Eugenio: "Il povero Valentino (poverissimo perché a quest'ora è morto anche lui) [...]" (2004, p. 1150). A segunda e última dessas menções ocorre na página seguinte: "Ma non vorrei dirne troppo male. [...] eppoi lasciò ad Antonia una bella sostanza" (2004, p. 1151).

O último dos três modos em análise de retomada da rivalidade inibida contra o genro é a resposta que Zeno dá como narrador - ao passo que não estava em condições de dá-la como protagonista - à explicação que Carlo formulou, quando foi diagnosticada a doença, sobre o envelhecimento precoce de Valentino com base no corpo envelhecido do tio, o qual era menos vivo em tudo, pois, por exemplo, precisava de menos ar e menos circulação, o que resultava em uma comparação com o genro que era desfavorável a Zeno:

A me tutto questo non parve molto logico. Ma non fiatai, anzi mi ritirai in me stesso, nel mio vecchio organismo, per proteggerlo da tanti scongiuri e vivere... tuttavia. Che cosa ne sanno costoro della vita? Il mio pensiero è ora più vivo di quanto mai fosse stato quello del povero Valentino. Non a me arriva d'ingarbugliarmi in un avvenimento d'importanza minima e analizzarlo più di quanto lo meriti per abbandonarlo solo quando tutti intorno a me sono mezzo morti dalla noia. Ciò dovrebbe pur provare che la mia respirazione è più abbondante di quanto fosse stata mai la sua. Ora mi rimproverano la mia distrazione, la mia incapacità di ricordare nomi e persone. Ma più o meno marcati tali difetti li ebbi sempre e se sono difetti da vecchio allora è provato ch'io seppi sopportare la vecchiaia non appena nato mentre Valentino ne fu ucciso a 40 anni. (2004, p. 1151-1152)

Inclusive, cogitamos que a afirmação do narrador sobre o próprio pensamento estar vivo talvez faça referência à própria resposta que Zeno finalmente consegue dar à formulação sobre a diminuição da vida na velhice ao escrever o parágrafo citado, o que seria mais uma expressão do rejuvenescimento propiciado pela escrita, conforme comentamos na seção anterior.

Uma vez que tratamos da rivalidade de Zeno contra Valentino no contexto da retomada da competição sexual pela filha, completemos a nossa análise dessa retomada 
abordando as hostilidades que o narrador dedica a Antonia devido à derrota humilhante que sofre nessa competição em sua própria casa pelo fato de a filha voltar a morar com os pais e permanecer inflexivelmente enlutada. Zeno não pode hostilizar Antonia diretamente, pois agiria contra a própria competição sexual que o impele a ser hostil com a filha. Nesse caso, a escrita opera de maneira equivalente à escrita de manifestações de rivalidade que são vedadas ao protagonista.

Assim, a recusa das freiras ao desejo de Antonia de entrar para a vida monástica quando ainda era uma jovenzinha inspira ao narrador a seguinte hipótese sobre a razão para a decisão das freiras: "Adesso che scrivo scopro che forse esse avevano indovinato Antonia e avevano scoperto ch'essa sarebbe stata nel convento la stessa seccatura ch'è proprio ora in casa nostra" (2004, p. 1147). Encontramos outras manifestações de hostilidade à filha quando Zeno trata da rejeição dela aos costumes liberais que foram concedidos às senhoritas após a guerra, tal como o direito a andar sozinha fora de casa. São três frases consecutivas em discurso indireto livre com afirmações bastante hostis considerando que Zeno se refere à própria filha: "Insomma essa era come una piccola balla di merci che aveva bisogno dello speditore per moversi. E sapeva difendere questa sua schiavitù elettiva come Alfio la sua pittura. Quando parlava delle altre fanciulle era maligna come una vecchia disillusa [...]” (2004, p. 1148). Propomos que essa sequência de hostilidades poderia ser atribuída exclusivamente ao narrador tanto porque Alfio ainda não se dedica à pintura no episódio relatado, dado que se torna pintor em 1923 ou depois, quanto porque as referências à escravidão voluntária e à velhice desiludida parecem mais compatíveis com a condição extrema de viúva que se nega a encerrar o período de luto do que com a mencionada rejeição à liberalização dos costumes.

Em seguida, Zeno escreve um parágrafo no qual aborda os gastos excessivos de Antonia com a sua beleza e com roupas (2004, p. 1148). Após comentar que a indisposição contra a esposa e a filha por causa desses gastos pareciam feitas para colocá-lo do lado errado, o narrador encerra o parágrafo afirmando que fica furioso quando se encontra desse lado por causa do artifício de outrem que lhe parece inimigo. Trata-se de uma qualificação muito inusitada num contexto de dissabores razoavelmente ordinários com a esposa e a filha, de modo que consideramos que essa é mais uma repetição causada pelo desejo de hostilizar Antonia. Ainda mais inusitada é a próxima hostilidade que o narrador dedica à filha, pois sugere que Eugenio se apaixona por ela apenas depois de entrar na guerra na medida em que ela se torna uma alternativa ao 
enfrentamento com o exército inimigo: "Finché era stato a Trieste la sua simpatia per Antonia non s'era rivelata a nessuno. Io mi figuro che poi, quando poteva liberarsi dalla vita della trincea [...], facilmente se ne innamorò, perché certamente il salotto di Antonia era tuttavia preferibile alla trincea" (2004, p. 1149).

Por fim, após narrar o estabelecimento da situação derradeira da competição sexual por Antonia, ou seja, a decisão dela de aceitar o convite para voltar a morar com os pais, Zeno ainda acrescenta a seguinte reação hostil que tem ao recordar a filha nessa ocasião: "io penso: 'Cara, bella, piccola megera che vuol piangere tanto, ma non vuol piangere sola"” (2004, p. 1157).

Uma vez que expusemos como o narrador retoma a competição sexual com Valentino por Antonia recorrendo à extrapolação da mera atividade narrativa, tratemos da retomada correspondente da rivalidade edipiana contra o filho. Esta é bem menos expressiva do que aquela porque a história da relação de Zeno com Alfio já trata dos dissídios entre eles e da tentativa do protagonista de se reconciliar com o filho. Destaquemos duas ocorrências da retomada em análise. A primeira delas é uma acusação de incoerência contra Alfio, a qual Zeno escreve após relatar o simples ato de receber o troco de duzentas liras pelo quadro que comprou do filho:

So, che coi denari egli ha un'accuratezza che non sta in relazione alle sue
idee scomposte sulla ricchezza. In questo mi è superiore di molto ed io mi
compiaccio di tale sua superiorità ch'è molto ammirata da sua madre. Non
spende nulla ciò che potrebbe avvicinarlo ai suoi simili poveri, ma ha il
portamonete sempre ben fornito ciò ch'evidentemente ne lo allontana. (2004,
p. 1130)

Tal hostilidade seria estranha ao protagonista no exato momento que está sendo bem sucedido no propósito de se reconciliar com o filho. Ressaltemos também que essa acusação do narrador atinge a única decisão do filho que muda o rumo dado à própria vida que não desencadeou um conflito com o protagonista, o envolvimento dele com o comunismo; de fato, as demais decisões dessa magnitude que foram tomadas por Alfio - o abandono da escola, a adesão ao ideal da personalidade e a dedicação à pintura terminam nos dissídios com pai que são narrados no texto em análise.

Dado que a outra ocorrência da retomada da rivalidade edipiana contra Alfio que escolhemos para destacar já opera segundo a forma recorrente da depreciação pela associação hereditária, comecemos apresentando essa forma: ela consiste em usar a ligação de duas ou mais pessoas por meio da hereditariedade como pretexto para estabelecer uma comparação entre elas que resulte na depreciação de uma delas. Ora, a 
outra ocorrência na qual o narrador retoma a rivalidade em questão é constituída por um parágrafo dedicado à descrição física de Alfio, a qual está repleta de imperfeições da sua aparência, inclusive com a contraposição ao que Augusta acha belo no seu rosto, de modo que se trata de uma concentração tal de hostilidades de Zeno contra o próprio filho que a rivalidade velada do protagonista o impede de declará-las a qualquer personagem. Além de a declaração concentrada de hostilidades ser admitida pela escrita autobiográfica, o narrador recorre à novidade da aparência de Alfio em termos hereditários como pretexto para finalmente registrar essa declaração, conforme podemos constatar pela frase de abertura do parágrafo mencionado: "E anche la sua figura egli la aveva inventata perché nessuno dei suoi antenati l'aveva avuta” (2004, p. 1128).

O parágrafo anterior ao que mencionamos também aborda a novidade hereditária, mas em termos do comportamento do filho como pintor. Assim, ao descartar o sogro como fonte hereditária da rebelião de Alfio, Zeno aproveita para escrever ofensas sobre o antigo rival: "E suo nonno Giovanni non seppe che cosa fosse, lui che tanto comodamente, grosso e grasso come era, sedeva sulla schiena degli altri" (2004, p. 1128). Ressaltemos que essa repetição da rivalidade edipiana contra o sogro não é um resultado isolado; na verdade, a associação pela hereditariedade permite que o narrador também retome a compulsão repetitiva em relação a qualquer um dos seus antigos rivais que seja ascendente de algum dos personagens do seu relato, ainda que esse rival seja estranho ao trecho da narrativa no qual foi inserido.

Finalizemos a presente análise do texto Le confessioni del vegliardo tratando de outra ocorrência da depreciação pela associação hereditária que apresentamos no penúltimo parágrafo. $\mathrm{O}$ narrador usa esse recurso para mencionar o fracasso comercial da empresa de Guido a partir de uma comparação com Carlo: "In quanto a Carlo che aveva hereditato da suo padre Guido tanti difetti ma non la mancanza di spirito che lo rovinò, capace com'era stato di fare i bilanci più ridicoli senza saperne ridere [...]" (2004, p. 1123).

O próximo texto que abordaremos na presente investigação é Umbertino, começando pelas repetições do recalcado que a depreciação pela associação hereditária proporciona apenas ao narrador. Ele usa novamente esse recurso para depreciar o rival Guido por meio do filho em duas oportunidades. A primeira delas abre a narrativa que Zeno dedica ao sobrinho: "Carlo è veramente una persona tanto divertente che si può svagarsi già mettendosi a parlare di lui. Anche lui apparentemente non avrebbe nulla del padre suo" (2004, p. 1183). Podemos entender que Carlo the proporcionou mais uma 
diversão pela depreciação do rival. A segunda oportunidade surge com um episódio no qual Carlo se destaca ao se defender de uma acusação de ignorância como médico. Eis como o narrador aproveita esse relato para hostilizar não só Guido, mas também Giovanni, ainda que por vias mais tortuosas:

\begin{abstract}
E adesso qualcuno mi vada a scoprire somiglianze con Guido in Carlo. Guido ch'era petulante finché poteva aggredire, ma che perdeva la parola non appena sentiva sul proprio corpo la pressione dell'aggressore.

Certo tutto questo istinto di buon affarista di quel magnifico medico [...] poteva venire dal nonno Giovanni Malfenti. Ma prima di tutto io so che in mio suocero l'istinto degli affari si sviluppò tardi, anzi insieme alla sua grossa pancia. Ma poi come sarebbero pervenute al fine Carlo della qualità di quel grosso e grezzo uomo ignorante, qualità ch'io m'ero abituato a considerare proprio connaturate a quel suo adipe, alla meditazione che naturalmente in lui si faceva sedata e tranquilla? (2004, p. 1191)
\end{abstract}

Por fim, a narrativa sobre o sobrinho termina com a depreciação pela associação hereditária sendo usada contra Alfio. Ao abordar o hábito tabagista de Carlo, o narrador também comenta como é o hábito do filho e recorre à própria associação hereditária com ele para declarar implicitamente a vitória sobre Alfio em uma competição referente ao modo de fumar: "Fuma molto ma molto volentieri e sempre delle sigarette squisite. Alfio fuma anche lui ma rabbiosamente il suo puzzolente sigaro toscano. Neppure nel fumo non ha ereditato nulla da me" (2004, p. 1191).

Destaquemos outro modo pelo qual o narrador retoma as repetições inibidas, o da extrapolação da mera atividade narrativa na medida em que o protagonista está impedido de exercer tais repetições, ao menos de forma minimamente satisfatória. Mais uma vez, já encontramos o recurso usado pelo narrador ao investigar o texto Le confessioni del vegliardo: tal como a descrição escrita da aparência de Alfio propicia um exercício da rivalidade edipiana ao narrador que é vedado ao protagonista, o mesmo tipo de descrição dedicado a Renata propícia uma declaração clara da admiração que o seu corpo provoca em Zeno, ao passo que o protagonista evita que a sua admiração pelo corpo feminino seja percebida desde que foi educado por Felicita. Logo, citemos a descrição que Zeno faz de Renata após afirmar que acompanhou Augusta no amor pela empregada:

Certo in me non si muove altro che un amore paterno vecchio come sono. Ma mi piace di vederla così giovine, ben messa, la piccola figurina su quelle gambe un po' lunghe, svelta e nervosa. Há una testina che non è una perfezione, ma graziosissima con quei capelli bruni ricciuti, gli occhi vivi, i denti belissimi. (2004, p. 1192)

Podemos mesmo dizer que a descrição de Renata funciona para o narrador 
como a saudação que o protagonista dirige à jovenzinha que ele confunde com a filha de Dondi (2004, p. 1221) no texto Il mio ozio no sentido de que ambas as expressões produzidas por Zeno servem para que sinta melhor a beleza da mulher que lhe induz essa expressão. Exatamente por causa dessa saudação, consideramos que a extensa descrição que Zeno faz da jovenzinha (2004, p. 1222-1223) no texto Prefazione já é uma repetição da admiração por ela que expressou como protagonista ao saudá-la.

Por fim, os textos Il mio ozio e Prefazione são menos importantes do que os anteriores para a presente investigação. Consideramos que, no primeiro deles, as repetições edipianas do protagonista sejam suficientemente abrangentes para que o narrador quase não seja compelido a acrescentar repetições que extrapolem aquelas que a própria atividade narrativa proporciona, talvez porque, em vez de a história ser dedicada aos parentes ou a uma empregada que mora na casa de Zeno, ela trate basicamente de cuidados com a saúde, de uma amante e de Misceli, um rival que não é íntimo do protagonista. Além disso, o episódio de Felicita por si só provê a retomada da repetição do recalcado que foi inibida pelo impasse sexual que a própria amante provocou. Assim, não deve nos surpreender que a ocorrência que nos parece mais relevante de uma recorrência edipiana que seja exclusiva do narrador se deva a um personagem que não só está ausente da história do texto em análise, Copler, mas também morreu há décadas devido a uma paralisia renal. Ora, Zeno não perde a oportunidade de remeter à morte do rival após relatar os cuidados dedicados aos rins: "Sarebbe bella che gli altri che alle reni mai pensano abbiano un loro funzionamento sicuro mentre io che ad esse ogni settimana porto un sacrificio possa essere remeritato improvvisamente con la sorpresa che toccò al povero Copler" (2004, p. 1199).

No tocante ao texto Prefazione, consideramos que justamente o fato de ser dedicado à própria escrita instrumentaliza os seus trechos narrativos a ponto de desfavorecer o exercício de repetições do recalcado que sejam alheias ao protagonista. Apesar disso, encontramos nesse texto uma repetição exclusiva do narrador que se destaca por retomar a mais antiga e mais trivial rivalidade edipiana de Zeno, ou seja, aquela voltada contra o pai. De fato, ao tratar do livrinho que o pai usava para anotar o que precisava fazer, o narrador aproveita para hostilizar o pai uma vez mais com base numa falha que ele cometeu num assunto bastante delicado:

Egli credeva nell'efficacia delle raccomandazioni che seppeliva in quel libretto. Io ho la prova che la sua fiducia era messa male. Ne trovai una che dice: Assolutamente (e questa parola è sottolineata) non devo dimenticare di dire all'Olivi quando se ne presenti l'occasione che mio figlio alla mia morte dovrà apparire verso tutti quale il vero padrone benché tale non sarà mai. 
[...] ci voleva un ingenuo come mio padre per credere di saper dirigere il proprio futuro. (2004, p. 1230-1231)

Ora, o pai não cumpriu essa intenção anotada no seu livrinho, e uma longeva repetição edipiana está vinculada a essa falha, a disputa pelo controle dos negócios paternos, a qual examinamos na segunda seção do segundo capítulo. Nesse trecho, há um aspecto importante sobre os resultados da escrita de Zeno, o qual fica ainda mais em evidência quando Zeno hostiliza o pai mais uma vez por causa do livrinho nos últimos parágrafos do texto Prefazione, mas essas questões pertencem à investigação que faremos na próxima seção.

Em suma, verificamos na presente seção que os tempos da narrativa e da narração satisfazem a seguinte condição decorrente da constituição de Zeno como narrador: durante a atividade narrativa, Zeno retoma as repetições do recalcado que estão inibidas no final do tempo da história. Além disso, identificamos, como parte dessa verificação, que a referida condição é satisfeita pelo narrador tanto por meio de repetições edipianas que já atuavam satisfatoriamente no protagonista, opcionalmente acrescentando ocorrências específicas ao tempo da narração, quanto por meio de repetições edipianas que o protagonista poderia exercer apenas de modo insatisfatório ou nem mesmo seria capaz de exercer.

\subsection{As consequências da constituição de Zeno como escritor: o limite da retomada das repetições do recalcado e as suas consequências para as articulações temporais das "continuações"}

Na seção anterior, expusemos como o narrador é bem sucedido em retomar as repetições do recalcado que estão inibidas na situação final do protagonista. Na presente seção, terminaremos de explorar os resultados das três seções anteriores investigando o limite da referida retomada e as suas consequências principais para os tempos da narração e da narrativa.

Antes de começarmos a investigação que propusemos para a presente seção, esclareçamos que a base da elaboração temporal das "continuações" é igual à das seções intermediárias do último capítulo do romance, já que o protagonista tem uma recaída para as repetições da rivalidade edipiana, conforme analisamos na seção inicial deste 
capítulo. De fato, conforme estabelecemos nas seções anteriores, a temporalidade linear é rejeitada em favor da temporalidade de onda e o narrador escreve como um modo de reagir à temporalidade da nota única por meio da exercício das repetições do recalcado durante a atividade narrativa.

Logo, tal como nas partes intermediárias do último capítulo do romance, são cruciais para as "continuações" as articulações entre as temporalidades de onda, da nota única e da repetição da rivalidade edipiana, mas há diferenças entre os dois casos, dentre as quais estão aquelas que analisamos na segunda seção deste capítulo. Na presente seção, justamente exploraremos essas diferenças a partir das consequências do limite da retomada das repetições inibidas. Por fim, devemos sempre considerar que o texto $U n$ contratto possui uma organização temporal que lhe é específica, da qual já tratamos nas duas seções iniciais deste capítulo.

Comecemos a investigação da presente seção abordando o limite para a retomada das repetições edipianas da qual Zeno se tornou capaz ao voltar a se dedicar à escrita autobiográfica. Retornando à última citação da seção anterior, encontramos esse limite em operação no fato de que a repetição obtida pelo narrador recorrendo à anotação do pai se revela bastante danosa, pois justamente retoma a grande derrota para o pai, não só pela introdução de um elemento segundo o qual a decisão paterna de que Olivi controlaria os negócios é reafirmada, qualquer que seja o motivo pelo qual a intenção anotada não foi cumprida, mas também pelo teor profético do final da anotação, uma vez que a declaração de que deve parecer para todos que Zeno seja o patrão sem que jamais o seja efetivamente se cumpre desde que ele assinou o novo contrato com o filho de Olivi! Consideramos que as afirmações dedicadas ao tempo no parágrafo seguinte tentam exatamente desfazer essa impressão de que o pai previra o futuro e reservam a imagem das gotas para a retomada das repetições inibidas pela escrita: "Ma già ogni sforzo per trasferirsi da un tempo nell'altro è vano [...]. Può essere che il tempo non esista [...] ma esistono certamente i recipienti che lo contengono e sono quasi chiusi. Spandono solo poche goccie dall'uno nell'altro" (2004, p. 1199).

Logo, mesmo após o retorno de Zeno à escrita, a disputa pelo controle dos negócios paternos continua tão inibida para Zeno como agente quanto estava para ele desde a assinatura do novo contrato. De modo geral, o limite em análise consiste em que Zeno retoma as repetições edipianas apenas no âmbito da escrita, e, portanto, elas continuam tão inibidas fora desse âmbito quanto antes de ele voltar a escrever. Propomos que o final do texto Prefazione justamente consiste numa abordagem desse 
limite na sua forma geral, ainda que inclua mais uma ocorrência da rivalidade edipiana contra o pai:

Sono stanco di scrivere per questa sera. Augusta che poco fa mi chiamò oltre il corridoio a quest'ora si sarà addormentata $[\ldots]$.

Il suo sonno è tuttavia leggero ma più rumoroso che in passato [...]. Orrenda macchina questa nostra quando è vecchia! Se ho assistito allo sforzo di Augusta, pavento quello che incombe a me e non raggiungo il sonno se non mi concedo una doppia dose di sonnifero [...].

E qui mi faccio una raccomandazione ad imitazione di quelle di mio padre: Ricordati di non lagnarti troppo della vecchiaia in queste annotazioni. Aggraveresti la tua posizione.

Ma sarà difficile non parlarne. Meno ingenuo di mio padre so subito che questa è una raccomandazione vana. Essere vecchio il giorno intero senz'un momento di sosta! E invecchiare ad ogni istante! M'abituo con fatica ad essere come sono oggi e domani ho da sottopormi alla stessa fatica per rimettermi nel sedile che s'è fatto più incomodo ancora. Chi può togliermi il diritto di parlare, gridare e protestare? Tanto più che la protesta è la via più breve alla rassegnazione. (2004, p. 1233-1234)

No início da citação, tão logo Zeno cessa de escrever, é confrontado com a velhice, na qual as suas repetições edipianas continuam inibidas, e se queixa desse estado lamentável. Assim, concluímos que a situação final do narrador no texto Prefazione reafirma em termos gerais a inibição dessas repetições, o que nos remete ao resultado que obtivemos na segunda seção do presente capítulo: a situação final do protagonista em cada narrativa das demais "continuações" é a da inibição de uma das suas repetições edipianas.

Nos dois parágrafos finais da citação, Zeno recomenda a si mesmo que não se lamente muito da velhice, mas reconhece que é incapaz de seguir essa recomendação, de modo que a escrita não é uma vitória sobre a inibição das repetições edipianas na medida em que se articula um embate entre a escrita autobiográfica, na qual Zeno é capaz de retomar essas repetições, e a vida na velhice, na qual elas permanecem inibidas.

Abordemos também um trecho do texto Prefazione que consideramos uma expressão indireta do limite da retomada das repetições inibidas pelo resultado absurdo que supõe que a dedicação à escrita produziria no caso da jovenzinha na praça Goldoni: "A quella fanciulla non avrei attribuito un nome che, quasi certo, non le appartiene. L'avrei semplicemente guardata come può colui cui il signor Iddio conservò la vista. Da capo a piedi" (2004, p. 1226). Logo, em vez da retomada da repetição edipiana pela via indireta do próprio passado, Zeno supõe que a escrita autobiográfica poderia torná-lo capaz da imediata repetição do recalcado, o que nos parece compatível apenas com a situação anterior ao impasse sexual que a relação com Felicita lhe causou. Como 
nenhuma realização do narrador que seja comparável a essa suposição aparece nas "continuações", reforçamos a nossa avaliação de que a escrita é incapaz de romper o limite em questão.

Uma vez que esclarecemos que Zeno retoma as repetições inibidas apenas no âmbito da escrita e que essa limitação origina um embate entre a escrita autobiográfica, na qual transcorre a retomada, e a vida, na qual a inibição das repetições permanece, investiguemos as principais consequências desse embate para a elaboração dos tempos da narração e da narrativa.

Para o tempo da narração, propomos que a consequência mais importante do embate entre a vida e a escrita está principalmente nos trechos nos quais Zeno não se dedica ao próprio passado, pois, ao se restringir ao próprio tempo da narração, ele é incapaz de ignorar que a inibição das repetições permanece fora do âmbito da escrita. Assim, a nossa proposta é que vários trechos dedicados ao próprio tempo da narração incorporam indiretamente $\mathrm{o}$ embate em análise na própria escrita privilegiando elementos passíveis de operarem segundo esse embate, o que resulta, por exemplo, na abordagem da própria escrita autobiográfica ou da oposição entre o passado e o futuro. Encontramos tais trechos nos textos Le confessioni del vegliardo e, principalmente, Prefazione.

Quanto ao texto Le confessioni del vegliardo, destaquemos um trecho que pertence ao próprio parágrafo de abertura:

Di questi giorni scopersi nella mia vita qualche cosa d'importante, anzi la
sola cosa importante che mi sia avvenuta: La descrizione da me fatta di una
sua parte. [...] Come è viva quella vita e come è definitivamente morta la
parte che non raccontai. Vado a cercarla talvolta com ansia sentendomi
monco, ma non si ritrova. E so anche che quella parte che raccontai non ne è
la più importante. Si fece la più perché la fissai. Ed ora che cosa sono io?
Non colui che visse ma colui che descrissi. Oh! L'unica parte importante
della vita è il raccoglimento. Quando tutti lo comprenderanno con la
chiarezza ch'io ho tutti scriveranno. La vita sarà letteraturizzata. [...] E il
raccoglimento occuperà il massimo tempo che cos̀ sarà sottratto alla vita
orrida vera. [...] E la propria vita risulterà più chiara o più oscura ma si
ripeterà si correggerà si cristallizzerà. Almeno non resterà quale è priva di
rilievo, sepolta non appena nata, con quei giorni che vanno via e
s'accumulano uno eguale all'altro a formare gli anni, i decennî, la vita tanto
vuota, capace soltanto di figurare quale un numero di una tabella statistica del
movimento demografico. (2004, p. 1116-1117)

Logo, Zeno contrapõe a escrita autobiográfica à própria vida, a qual inclusive é apresentada em termos especificamente compatíveis com a temporalidade da nota única no final da citação, e claramente declara a vitória da primeira sobre a sua vida presente e sobre o que já viveu. Nos dois casos, consideramos que a base dessa vitória está 
justamente no afastamento que a escrita propicia em relação à vida.

No primeiro caso, Zeno se afasta da vida presente graças ao recolhimento necessário para se dedicar à escrita. No segundo caso, ele pondera que o que permanece da vida passada e se torna a principal parte dessa vida é aquela fixada pela escrita, o que resulta no afastamento da experiência passada que não foi narrada, independentemente da importância que possa ter. Além disso, mesmo a parte do passado que permanecer por meio da escrita será alterada nesse processo, e a referência à correção do que aconteceu é especialmente significativa para a nossa argumentação (para não falar sobre a menção à repetição, que obviamente ganha uma imensa ressonância no contexto do presente trabalho).

O texto Prefazione também possui um trecho dedicado aos manuscritos que começou a escrever por recomendação do doutor S. (2004, p. 1227-1228). Não o comentaremos, pois é desenvolvido com termos bastante similares aos da citação anterior, de modo que a nossa análise é válida para ambos os trechos. A nossa proposta para o texto Prefazione é que o embate entre a vida e a escrita se torna recorrente a partir do trecho no qual Zeno faz as últimas referências ao episódio inicial, o da falsa Dondi, e começa a abordar diretamente a própria dedicação à escrita, permanecendo assim até os últimos parágrafos, os quais já comentamos ao apresentarmos o embate em análise na presente seção. Eis como Zeno introduz a sua atividade como escritor após se questionar sobre a razão pela qual não se recordou antes da verdadeira Dondi e não entendeu o que lhe interessava nela:

Perché non la vidi non l'intesi prima? Forse nel presente ogni avvenimento è
oscurato dalle nostre preoccupazioni, dal pericolo che su noi incombe? E non
lo vediamo, non lo sentiamo che quando ne siamo lontani, in salvo?
Ma io qui nella mia stanzetta posso subito essere in salvo e raccogliermi su
queste carte per guardare e analizzare il presente nella sua luce
incomparabile. E raggiungere anche quella parte del passato che ancora non
svanì. Descriverò dunque il presente e quella parte del passato che ancora non
svanì non per serbarne memoria ma per raccogliermi. (2004, p. 1226)

Propomos que os parágrafos da citação isolam dois contextos. Quanto ao primeiro parágrafo, consideramos que aborda um acontecimento pelo qual o protagonista retoma pontualmente as suas repetições inibidas, tais como o episódio da jovenzinha na praça Goldoni ou a operação de rejuvescimento no texto Le confessioni del vegliardo, o que destaca o contraste entre o passado das repetições edipianas e a vida da inibição da rivalidade edipiana, na qual se encontra também o narrador. Frente a tal contraste, Zeno manifesta a rejeição de tal vida destacando as preocupações e os 
perigos aos quais ela the expõe e concebendo um ideal de recolhimento.

No tocante ao segundo parágrafo da citação, Zeno trata da sua dedicação à escrita autobiográfica, por meio da qual realiza o ideal de recolhimento. Além do recolhimento intrínseco a essa dedicação, consideramos que o fato de se tratar de uma escrita autobiográfica também realiza o ideal em análise na medida em que o narrador se afasta da sua vida presente retomando as repetições inibidas pelo recurso a um passado geralmente anterior a essa inibição. Propomos que esse afastamento é a razão pela qual Zeno rejeita explicitamente o resguardo da memória.

Consideramos que a experiência que Zeno fornece de exemplo para a medição da duração do presente é elaborado, em grande medida, com as mesmas relações que propusemos para a concepção da escrita como recolhimento, apesar de recorrer a meios mais indiretos:

\begin{abstract}
Non vedemmo più la strada e neppure i campi $[\ldots]$ ma soltanto innumerevoli dolci, verdi colline che ci impedivano di vedere altro che le vicine enormi montagne dalle cime di roccia azzurra che ci guatavano molto serie. [...] scorsi una casetta ai piedi della collina e dinanzi ad essa un uomo che con colpi vigorosi di un maglio piegava su un'incudine un pezzo di ferro. E come un bambino ammirai che il suono metallico di quell'incudine arrivava al mio orecchio quando il maglio da lungo tempo s'era risollevato per prepararsi a ripetere il colpo [...].

[...] Poi intervene la serietà del ricordo, la logica della mia mente a correggere i disordini della natura e quando ora ripenso a quel maglio, immediatamente come esso raggiunge l'incudine sento echeggiare il suono ch'esso provoca. Certo, nello stesso tempo, qualche cosa dello spettacolo si falsò. Al disordine del presente si sostituì il disordine del passato. Quella famiglia di colline si fece anche più numerosa e furono tutte più ricche di boschi. Anche le roccie delle montagne divennero più fosche ancora e più serie forse anche più vicine, ma tutto era regolato e intonato. (2004, p. 1229-1230)
\end{abstract}

Novamente propomos que os parágrafos da citação isolam dois contextos. No que tange ao primeiro parágrafo, consideramos que a alegria produzida por uma situação afastada visual e espacialmente do cotidiano do protagonista pode operar como alusão a qualquer acontecimento pelo qual ele retoma pontualmente as suas repetições inibidas. Do mesmo modo, a falta de sincronismo entre a visão e o som, a qual é tratada como desordem do presente no parágrafo seguinte da citação, aludiria ao contraste entre o acesso direto à vida desprovida das repetições edipianas e a mediação pela recordação para acessar o passado da rivalidade edipiana.

No segundo parágrafo da citação, propomos que se faz a passagem da vida presente de Zeno para o passado evocado pela escrita autobiográfica. Segundo a nossa proposta, o som e a visão são sincronizados no sentido de que Zeno justamente retoma as repetições inibidas na medida em que está entregue à narrativa autobiográfica. Em 
contrapartida, surge a desordem do passado: há uma ampliação do que foi valorizado no momento recordado, apesar de tudo ficar regulado e no devido tom. Consideramos que se trata de uma descrição da alteração que a narrativa de Zeno realiza no que é recordado e que ela corresponde às repetições do recalcado que o narrador acrescenta às do protagonista, uma vez que as recorrências edipianas de ambos geralmente não são conflitantes.

Os episódios finais do texto Prefazione mudam a maneira pela qual é abordado o embate entre a vida e a escrita. No que se refere ao episódio do livrinho de anotações do pai de Zeno, propomos que ele justamente é escrito devido à oposição entre o passado e o futuro por meio da qual incorpora o embate em análise, conforme somos inclinados a pensar pelas frases que Zeno escreve no início do trecho em questão: " $\mathrm{E}$ così terminerò la mia vita con un libretto in mano come il mio defunto padre. Come avevo riso io di quel libretto. È vero che ne sorrido anche ora ricordando ch'egli lo destinava proprio al futuro" (2004, p. 1230). Logo, o narrador opõe a sua dedicação a escrever sobre o próprio passado ao livrinho que o seu pai destinava a lembretes de tarefas que deveria fazer. Ora, consideramos que a razão pela qual o seu pai escrevia é totalmente inconcebível para Zeno na situação na qual vive ao escrever essas frases na medida em que se encontra desprovido de propósitos dignos de serem anotados devido à inibição das suas repetições edipianas.

A preferência pelo passado em detrimento do futuro é até mesmo abordada, ainda que excepcionalmente, num trecho dedicado à narrativa no texto Un contratto. Nesse trecho, Zeno reflete sobre a própria disposição em relação ao tempo após relatar um momento da história no qual devia se preparar para receber a visita de Valentino, mas só consegue pensar sobre o encontro que teve com o filho de Olivi: "Ed è proprio vero ch'io più intensamente rivolgo il mio pensiero al passato come per correggerlo anzi un evidente tentativo de falsarlo - piuttosto che all'avvenire su cui il pensiero non sa come adagiarsi non vedendone chiaro il piano che non è ancora formato" (2004, p. 1102). Comentemos apenas que já encontramos a ideia de correção do passado por meio da narrativa na presente seção ao tratarmos do parágrafo inicial do texto Le confessioni del vegliardo e que, para o narrador, o futuro desconhecido está fora do âmbito da narrativa autobiográfica e, portanto, relegado à inibição das repetições edipianas.

Por fim, investiguemos os episódios finais do texto Prefazione, nos quais Zeno se propõe mesmo a abordar o exato momento da escrita. O primeiro deles trata do violino. Já comentamos na última seção do segundo capítulo que esse instrumento está 
associado no terceiro romance com a dupla temporalidade vivenciada por Zeno, a dos acontecimentos no presente e a das repetições do recalcado que ele acrescenta à primeira. Com o nosso comentário em mente, apreciemos o seguinte trecho:

\begin{abstract}
È scomparso da pochi giorni dal suo posto il mio violino ed anche il leggìo. ̇̀ vero che così fu conquistato al grammofono il posto che gli occorreva per espandere più vigorosa la sua voce. [...] avrei voluto lasciare il suo posto al violino. Non lo toccavo da quasi due anni. S'era fatto nelle mie mani oltrecché aritmico anche malsicuro e la mia cavata pareva diminuisse. Ma amavo di vederlo lì al suo posto in attesa di tempi migliori mentre Augusta non comprendeva perché dovesse ingombrare la mia stanza. [...] Finì ch'essa un giorno spinta dalla sua mania di fare ordine lo allontanò [...]. E perciò eccomi staccato definitivamente da un'altra parte della mia giovinezza. Augusta non ha ancora compreso quanti riguardi bisogna avere con un vecchio. (2004, p. 1231-1232)
\end{abstract}

Vinculando o referido comentário sobre o violino à declaração de Zeno de que o afastamento do instrumento foi uma separação de outra parte da sua juventude, propomos que Zeno associa, ainda que involuntariamente, a gradual separação do violino com o processo de inibição das repetições edipianas: os novos defeitos no desempenho com o instrumento correspondem às crescentes dificuldades para manter o exercício dessas repetições; o abandono do violino remete à ampliação das repetições inibidas, ainda que ele tenha a expectativa de retomá-las na ação cotidiana; e o afastamento do instrumento corresponde à perda dessa expectativa.

Consideramos que a citação possui mais um elemento relevante, o da substituição do violino pelo gramofone. Destaquemos também que é declarado que a substituição torna mais vigorosa a voz do gramofone. Com base nessas relações com o violino e na oposição trivial entre escutar os sons produzidos por si mesmo ao tocar um instrumento e escutar os sons produzidos pelos outros, propomos que o texto associa o gramofone ao fim do exercício das repetições edipianas. Como reforço para a nossa argumentação, assinalemos que as duas vezes nas quais o protagonista chega a uma conclusão sobre a própria vida ouvindo o gramofone, ela comporta o fim do exercício de alguma repetição do recalcado, ainda que ele obviamente abandone a conclusão depois. A primeira delas está no seguinte trecho do texto Un contratto: "dopo qualche tempo al grammofono vidi pieno di compassione per me stesso [...] che io, povero vecchio, non avevo aperte che due vie: Mettermi a lavorare col dubbio di non saperlo fare o arrendermi all'Olivi” (2004, p. 1098). Nas duas opções, a rivalidade edipiana contra o filho de Olivi não pode mais ser exercida, como efetivamente acontece quando Zeno se rende a ele ao assinar o novo contrato. A segunda das conclusões em análise está no texto Il mio ozio: o protagonista ouve a nona sinfonia de Beethoven no 
gramofone e, por causa da interpretação que lhe dá, a qual é diferente das interpretações que lhe deu em outras oportunidades, decide abandonar Felicita (2004, p. 1213).

Em suma, propomos que, no contexto do embate entre a vida e a escrita, a substituição do violino pelo gramofone corresponde à vida das repetições inibidas. Ora, o episódio seguinte, o do bêbado cantor, começa assim: "Ed altre novità in questa stanza non ci sarebbero se giusto ora non fosse inondata da suoni che non hanno nulla da fare con quelli del grammofono" (2004, p. 1232). Consideramos que o fato de Zeno iniciar o episódio pela plena oposição ao gramofone é o primeiro indício de que ele associa a canção do bêbado à própria escrita, pois ela está no outro extremo do embate. Verifiquemos quais são os demais elementos do episódio que podemos acrescentar ao primeiro indício.

Já comentamos, na terceira seção do presente capítulo, a suposição de Zeno de que o bêbado busca o passado por meio da antiga história da sua canção devido a sentir velho por ter um filho de vinte anos. Ela corresponde a uma das repetições inibidas de Zeno que o induz a escrever sobre o passado. Além disso, de modo equivalente às alterações causadas pelas recorrências edipianas de Zeno ao narrar a própria história, o bêbado produz involuntariamente alterações na música ao cantá-la: "Lungi da lui l'intenzione di inventare. Son sue certe appoggiature dalle quali striscia al suono giusto, ma non saprebbe farne a meno: gli facilitano la nota. Forse egli non sa di avere alterato la musica, e a quest'ora l'ama come è costretto di farla" (2004, p. 1232). Além de o narrador associar a canção do ébrio à própria narrativa, consideramos que ele concebe a relação entre o bêbado enquanto canta e enquanto não canta nos termos do seu embate entre a vida e a narrativa, ou seja, separando ao máximo os dois extremos:

\footnotetext{
Certo, sotto a quella musica c'è molto vino ma mai il vino ebbe un ufficio più nobile. Il mio cantore vive in quell'antichissima storia. Rinasce quella storia per lui due volte alla settimana e gli dà tutta la sorpresa e la commozione della cosa nuova. Come fa ad astenersi tutte le altre sere da quel vino che gli procura tanto gaudio? Quale esempio di moderazione!

[...] pensa al passato anche più lontano di quello che io ricerco. [...] Ci volero i settant'anni suonati a me per staccarmi dal presente. E ancora non sono contento e cerco di raggiungerlo anche adesso su queste carte.

Io non tenterò mai di fare la sua conoscenza. La sua voce fioca pare provenga da tempi lontani. [...] Non c'è il disordine che dà un'avventura intera. Quella voce solitaria ed io qui al mio tavolo che ne analizzo le esitazioni e il fervore. Un ordine perfetto! (2004, p. 1233)
}

Assim, o primeiro parágrafo da citação acumula elementos opostos ao cotidiano sóbrio do cantor: a embriaguez causada pelo vinho, a alegria da embriaguez, o passado remoto da história cantada e as emoções próprias à novidade. Quanto ao último 
elemento, como Zeno relata que o bêbado canta sempre a mesma canção, consideramos que a novidade remete ao contraste com o cotidiano.

Zeno se inclui nos dois parágrafos seguintes da citação. Ao aproximar a própria escrita do canto no segundo parágrafo, ele enfatiza a busca do passado e, portanto, o afastamento do presente. No tocante ao parágrafo final, propomos que Zeno defende a máxima separação entre vida e narrativa na medida em que aborda a sua relação com o cantor recusando encontrá-lo em favor de conhecer apenas a sua voz solitária enquanto ele mesmo permanece igualmente solitário no local onde, isolado do mundo, se dedica à escrita. No mesmo sentido, a desordem atribuída à aventura completa está em oposição à ordem perfeita do cantor e do escritor que relata a si mesmo ouvindo o cantor.

Com base nas nossas considerações, concluímos que Zeno, após lamentar a substituição do violino pelo gramofone, a qual associa à inibição das recorrências edipianas à qual está submetido no âmbito da ação propriamente dita, concebe o canto do bêbado como uma reação às repetições inibidas por meio da sua retomada no âmbito das narrativas cantadas, o que obviamente remete à retomada que Zeno realiza escrevendo narrativas.

Após examinarmos os sons do violino, do gramofone e do bêbado, estamos em condições de acrescentar um último comentário à análise que fizemos do episódio final do texto Prefazione no início da presente seção: o que remete Zeno à velhice, da qual passa a se queixar, também é um som, o da respiração rumorosa de Augusta dormindo. Como esse rumor é produzido por uma pessoa e está fora do âmbito da narrativa, consideramos que Zeno associa o rumor da esposa à própria inibição das repetições no sentido de impedimento de um ação esperada, o que é compatível com o efeito de Zeno voltar a se queixar da velhice depois de se entusiasmar com o bêbado cantor.

Em suma, resulta da nossa presente investigação que o embate entre a vida e a escrita autobiográfica é determinante tanto para que Zeno escreva trechos que, em vez de serem dedicados ao relato da vida do protagonista, são orientados para o próprio tempo da narração quanto para a abordagem dada por Zeno a esses trechos na medida em que os seus elementos são articulados de modo a operarem segundo esse embate.

Para encerrarmos a presente seção, investiguemos em que medida o embate entre a vida e a escrita autobiográfica determina a elaboração do tempo da narrativa nas "continuações". Comecemos tratando de dois aspectos temporais que são importantes para a nossa investigação. Quanto ao primeiro deles, retomemos uma das características que Zeno ressalta na velhice, a ausência de futuro, da qual tratamos na terceira seção 
como um efeito da temporalidade da nota única na qual Zeno se encontra. Abordemos outro aspecto dessa ausência que estava no trecho que citamos do texto Prefazione, mas que não consideramos durante a análise que fizemos na terceira seção: a relação com o futuro é assinalada por Zeno como a diferença entre os dois momentos nos quais se dedicou à escrita autobiográfica. Ele assinala a mesma diferença no trecho correspondente do texto Le confessioni del vegliardo (2004, p. 1117). Como o narrador do terceiro romance também estava submetido à temporalidade da nota única, concluímos que ainda não exploramos o bastante a ausência de futuro segundo a qual Zeno caracteriza a velhice.

No tocante ao segundo aspecto temporal, também é assinalado pelo próprio Zeno: por um lado, ele não tem nenhum futuro; por outro lado, tem um presente de múltiplos tempos. Encontramos a referência a essa multiplicidade no início do texto $I l$ mio ozio:

\begin{abstract}
Il mio presente si compone di varii tempi anch'esso: Ecco un primo lunghissimo presente: l'abbandono degli affari. Dura da otto anni. Un'inerzia commovente. Poi ci sono avvenimenti importantissimi che lo frazionano: Il matrimonio di mia figlia p.e., un avvenimento ben passato che s'inserisce nell'altro lungo presente, interrotto - o forse rinnovato o, meglio, corretto dalla morte del marito. La nascita del mio nipotino Umberto anch'essa lontana perché il presente vero in rapporto ad Umberto è l'affetto che oramai gli porto, una sua conquista di cui egli non sa neppure e che crede spettargli per nascita. (2004, p. 1197)
\end{abstract}

$\mathrm{Na}$ verdade, os dois aspectos temporais que destacamos podem estar vinculados, conforme nos sugere uma sentença do mesmo texto que opera com relações muito parecidas, ainda que o contexto seja diferente: "Da noi vecchi con la designazione di salute deve significarsi un indebolimento progressivo e contemporaneo di tutti gli organi” (2004, p. 1213). Em suma, o trecho citado nos sugere que os dois aspectos que apresentamos estão vinculados caso cada um dos tempos que compõem o presente de Zeno produza o resultado próprio à velhice segundo Zeno, a ausência de futuro.

Uma vez que introduzimos os dois aspectos temporais, investiguemos como eles estão relacionados com o tempo da narrativa nas "continuações", começando por ressaltar que ambos correspondem a resultados que obtivemos na segunda seção para o tempo da narrativa. Os múltiplos tempos que compõem o presente de Zeno correspondem às várias narrativas nas quais se dividem as "continuações" em detrimento da ordem cronológica; por exemplo, o abandono dos negócios é narrado no texto Un contratto e tanto o casamento e a viuvez da filha quanto a relação com o neto são assuntos de uma das narrativas que compõem respectivamente os textos Le 
confessioni del vegliardo e Il mio ozio.

A ausência de futuro corresponde à inibição das repetições do recalcado pelas quais terminam cada uma das narrativas que compõem os textos Un contratto, Le confessioni del vegliardo, Umbertino e Il mio ozio. Além disso, verificamos no início da presente seção que o narrador, no final do texto Prefazione, também é confrontado com a incapacidade da atividade narrativa para encerrar a inibição das repetições edipianas fora do âmbito da escrita.

Uma vez que assinalamos as correspondências dos dois aspectos temporais no âmbito da narrativa, ressaltemos que o vínculo sugerido entre eles está presente nesse âmbito: cada uma das narrativas dos textos das "continuações", exceto as do texto Prefazione, resulta na inibição de alguma repetição edipiana do protagonista. No caso do prefácio, devemos ponderar que a atividade narrativa não ganha um desenvolvimento autônomo porque os relatos estão subordinados à abordagem de Zeno para a escrita, a qual resulta na permanência das inibições às quais foi submetido o protagonista. Logo, o vínculo em análise é válido para o âmbito da escrita no texto Prefazione, de modo que devemos considerar o prefácio como um todo e Zeno como escritor em vez de protagonista.

Finalmente estamos em plenas condições de averiguar qual é a razão para que esse vínculo seja uma articulação generalizada das "continuações". Como ponto de partida da nossa averiguação, retomemos a alegação de Zeno de que a ausência de futuro seja a diferença entre os dois momentos nos quais se dedicou à escrita autobiográfica. Se desprezarmos o evento único que é a carta que encerra o terceiro romance de Svevo, o primeiro momento é o da autobiografia e o do diário. Conforme comentamos no terceiro capítulo, Zeno produz a autobiografia como uma recomendação do doutor S. para que sirva de preparação para a terapia psicanalítica, de modo que a própria escrita participa do exercício da repetição dos cuidados com a saúde. Conforme o nosso estudo no capítulo anterior, a escrita do diário é uma repetição da rivalidade edipiana contra o doutor $\mathrm{S}$. na medida em que é dedicada à rejeição da investida final do psicanalista para que Zeno retorne à terapia.

Em contraste com a autobiografia e o diário, a escrita das "continuações" não é uma repetição edipiana que implique alguma ação de Zeno no tempo da narração que esteja fora do âmbito narrativo. Com base nesse contraste, a nossa proposta é de que a ausência de futuro seja própria ao escritor das "continuações" porque ele não é capaz de retomar nenhuma repetição edipiana fora do âmbito da escrita. 
Em suma, propomos que se trata mais uma vez do embate entre a vida e a escrita autobiográfica e que a diferença de função que a escrita de Zeno exerce fora do próprio âmbito em cada uma das narrativas autobiográficas às quais Zeno se dedicou é crucial para que compreendamos em que medida tal embate determina a constituição do tempo da narrativa, não só no caso do vínculo que expusemos entre a ausência de futuro e as múltiplas narrativas, mas também de outro aspecto que diferencia as "continuações" do terceiro romance de Svevo, a desvalorização da sucessão temporal, da qual tratamos na segunda seção do presente capítulo.

Começando a abordar a função da escrita que mencionamos no parágrafo anterior pelo terceiro romance de Svevo, consideramos que a promoção pela narrativa do exercício de repetições edipianas fora do âmbito da própria escrita faz com que o narrador forneça um horizonte de prolongamento indefinido das ocorrências de repetições do recalcado no tempo da narração, o que é próprio da compulsão edipiana na medida em que ela sempre supõe uma próxima ocorrência numa sucessão potencialmente infinita. Consideramos que esse aspecto compulsivo da repetição do recalcado favoreça que a sucessão temporal seja mantida mesmo após a primeira cura parcial de Zeno, quando a temporalidade linear é reduzida a um nível residual. Na verdade, a própria sucessão indefinida das datas de um diário remete a esse avanço para a próxima ocorrência que é intrínseco à compulsão à repetição.

No caso das "continuações", como a escrita retoma as repetições inibidas apenas no próprio âmbito, é criado um embate com a vida submetida à inibição das repetições do recalcado. Consideramos que esse embate opera no âmbito da escrita das "continuações" reagindo ao exercício das recorrências edipianas dentro da narrativa por meio da rejeição da sucessão indefinidamente prolongada que a compulsão exige, seja pela desvalorização da sucessão temporal, seja pela recorrente afirmação do fim da narrativa pela justaposição de várias narrativas, as quais convergem para o próprio fim do exercício das repetições do recalcado.

Em suma, propomos que o contraste entre a escrita de Zeno ser ou não capaz de exercer as repetições do recalcado fora do âmbito da própria escrita é a base para que a autobiografia e o diário entreguem uma narrativa geralmente desenvolvida segundo a sucessão temporal, a qual remete à sucessão de ocorrências da compulsão à repetição, enquanto o tempo da narrativa nas "continuações" seja elaborado como uma justaposição de narrativas que desvalorizam a sucessão temporal e que se relacionam entre si pela convergência para a inibição das repetições edipianas de Zeno. 
Retomemos ressalvas que já fizemos no presente capítulo e que devem ser consideradas no contexto das conclusões que obtivemos. A sucessão temporal tanto é desvalorizada apenas no final do texto Un contratto, pois, nas suas partes anteriores, predomina a progressividade do processo de recaída de Zeno na rivalidade edipiana, quanto é adotada, em alguma medida, no episódio da relação com Felicita no texto $I l$ mio ozio, o que atribuímos ao fato de a retomada da atividade sexual do protagonista por meio da amante ser uma repetição edipiana tão bem sucedida, ainda que temporariamente, a ponto de causar uma suspensão na tendência do narrador a desvalorizar essa sucessão. O texto Prefazione contribui para a convergência geral das “continuações" para as repetições inibidas de Zeno no âmbito da sua escrita como um todo em vez do âmbito particular de cada uma das narrativas que o compõem. 


\section{CONCLUSÃO}

Uma vez que nos empenhamos nos quatro capítulos anteriores a investigar minuciosamente em que medida a compulsão à repetição do recalcado opera como a unidade temporal segundo a qual é construído o protagonista-narrador Zeno e são elaboradas as principais articulações temporais dos textos que compõem o nosso corpus - o romance La coscienza di Zeno e as "continuações" -, apresentaremos os principais resultados que obtivemos segundo a perspectiva que adotamos para o presente trabalho, esperando que sejam suficientes para comprovar a fecundidade da nossa proposta de análise para elaborar relações entre os mais diversos elementos literários dos referidos textos, e proporemos futuras investigações.

Dada a grande complexidade da nossa tarefa, começamos a nossa investigação no segundo capítulo do presente trabalho focando apenas no tempo da história dos textos do nosso corpus, além de desconsiderar o diário que encerra o romance devido às questões que lhe são específicas por causa do contexto clínico que o diferencia dos demais capítulos autobiográficos do romance.

Dentro do enfoque que demos ao segundo capítulo, obtivemos os primeiros resultados do nosso estudo ao realizarmos a tarefa básica de identificar as ocorrências mais simples das repetições do recalcado por parte do protagonista, ou seja, aquelas ocorrências nas quais o protagonista exerce uma repetição do recalcado sem que ela sofra perturbação relevante de outra compulsão repetitiva de Zeno. Esses resultados consistem em séries de ocorrências básicas de uma mesma repetição do recalcado por parte do protagonista, as quais reunimos em dois grupos.

O primeiro grupo que identificamos das séries básicas de repetições compulsivas do protagonista está baseado no desejo de Zeno pela mãe na medida em que aparecem relacionados com ela em algum dos poucos trechos dos quais ela participa: a unidade do objeto desejado, a totalidade desse objeto, o fetichismo, o canibalismo, o passo relutante ou outra reação contrária ao afastamento forçado da mulher desejada e o sorriso como reação à realização ou à privação do desejo de outrem. Além das declarações de Zeno a respeito das mulheres em geral participarem das três primeiras séries, cada uma das três principais mulheres da sua vida erótica na maturidade - Ada, Augusta e Carla - participa de duas ou mais dessas séries. 
O segundo grupo que identificamos das séries básicas de repetições compulsivas do protagonista está baseado na relação de rivalidade, da qual o pai é um dos principais representantes, já que participa de sete das nove séries desse grupo: a competição sexual, a rivalidade por meio do vício tabagista, a competição monetária, o desejo de morte, a rivalidade por meio da aparência dos cabelos, a oposição entre o riso e a seriedade, a tradução da rivalidade em termos espaciais ou respiratórios, a competição na qual Zeno está potencial ou efetivamente em desvantagem e a restrição compulsória da liberdade. Além do pai, participam dessas séries alguns personagens femininos e quase todos os principais personagens masculinos: o irmão, Olivi, Giovanni, a sogra, Ada, Guido, Copler, Carla, Lali, o doutor Muli, o filho de Olivi, Alfio, Valentino, Carlo, Cima, Umbertino, Bigioni, Fortunato, Felicita e Misceli.

Nem mesmo tivemos a intenção de sermos exaustivos na identificação das séries do segundo grupo, pois a lista que apresentamos já é bastante abrangente. Na verdade, as séries básicas que identificamos e reunimos em dois grupos são tão variadas, abrangentes e disseminadas pela narrativa e, ainda assim, tão pouco reconhecidas pelo próprio Zeno que avaliamos que elas precisam ser analisadas mesmo por abordagens críticas dos textos do nosso corpus que não recorrem à compulsão à repetição do recalcado. No caso da nossa proposta de investigação, repetições involuntárias que retomam características do desejo pela mãe e da rivalidade contra o pai remetem imediatamente ao complexo de Édipo como causa do conteúdo recalcado por Zeno, de modo que aceitamos o diagnóstico que o próprio romance fornece por meio do doutor S. (ainda que tenhamos sérias restrições ao modo limitado pelo qual ele o concebe, o que já pode ser deduzido das próprias séries básicas que elencamos).

Identificadas as séries básicas de repetições compulsivas do protagonista, tratamos dos casos mais complexos das suas repetições do recalcado, os quais envolvem conflitos entre elas, o que pode ocorrer tanto de modo transitório quanto pela instauração de ciclos. Ao estudarmos os conflitos transitórios, obtivemos dois resultados principais. O primeiro deles é a forma velada pela qual opera a rivalidade edipiana de Zeno devido ao conflito entre a própria rivalidade e a angústia de que a mãe ou uma das suas substitutas edipianas o julgaria uma pessoa má caso descobrisse a sua intenção hostil ao rival. Logo, Zeno geralmente exerce a rivalidade edipiana de modo a evitar que as manifestações hostis que decorrem dela possam ser reconhecidas por outrem e, caso alguém as reconheça, ele recua da hostilidade manifestada, o que ocorre de maneiras bastante diversas. A rivalidade velada nos permitiu compreender melhor casos que 
encontramos no romance e nas "continuações" que são tão diversos quanto os recuos abruptos do protagonista em disputas contra os adversários, o seu sentimento de culpa devido à realização do desejo de que algum deles morresse e, em três textos das “continuações”, as ocorrências nas quais ele pensa sobre a própria bondade.

O segundo dos resultados principais que obtivemos com base nos conflitos transitórios entre as repetições do recalcado foi a capacidade de esclarecer episódios que se destacam pelo comportamento bem pouco coerente do protagonista, conforme fizemos para o episódio do doutor Muli, relatado no terceiro capítulo do romance, e para a tentativa fracassada de Zeno de fazer as pazes com o filho, narrada no texto Le confessioni del vegliardo.

Abordar os conflitos transitórios entre as repetições do recalcado também nos deixou em condições de compreender que a proliferação de recorrências devido à compulsão à repetição não impede que vigore uma concepção da diegese como sucessão de acontecimentos durante a leitura na medida em que as repetições de Zeno geralmente não são reconhecidas como tais por ele mesmo; são múltiplas e se alternam entre si, tornando mais difícil identificar aquelas cuja distribuição é mais descontínua; e, por fim, estabelecem relações conflituosas entre si, de modo que uma determinada ação do protagonista pode ser efetivamente contrária a qualquer uma delas, desde que seja a realização de uma das outras.

Também estudamos a formação de ciclos por meio do conflito entre duas repetições do recalcado: Zeno começa o ciclo exercendo uma das recorrências, mas o conflito com a outra recorrência o faz renunciar à atitude inicial e o induz para a repetição opositora, a qual, pelo processo inverso, cede novamente a vez para o exercício inicial do ciclo, cuja duração, portanto, é indeterminada. Ao ciclo resultante do conflito denominamos repetição oscilatória.

Tal como no caso dos conflitos transitórios, a repetição oscilatória nos tornou capazes de esclarecer comportamentos bem pouco coerentes do protagonista, seja daqueles que se disseminam ao longo do romance e das "continuações", tais como a abstinência e o retorno ao tabagismo, tanto na forma dos últimos cigarros quanto na forma das orientações que Zeno recebe para parar de fumar, e os diversos cuidados com a saúde, seja daqueles que são restritos a uma determinada parte da história do protagonista, tais como o início da relação com Ada no quinto capítulo do romance, todo o relacionamento com Carla no capítulo seguinte e as confissões de Bigioni no texto Umbertino. Além disso, a análise da relação com Carla serviu para confirmarmos 
a capacidade dinâmica das repetições do recalcado na medida em que uma mesma repetição oscilatória pode assumir diversas configurações conforme mudam as circunstâncias que envolvem a sua realização, o que introduz um dinamismo na história que concede um aspecto difuso às recorrências, apesar de toda a sua abrangência e importância.

Finalizamos a investigação sobre a compulsão à repetição do recalcado no tempo da história dos textos do nosso corpus abordando a interrupção das repetições, seja em relação à tendência de Zeno a evitá-la, o que é intrínseco a um fenômeno compulsivo, seja no que tange à consequência de o protagonista se tornar incapaz de exercer as suas repetições compulsivas.

Quanto à tendência a evitar a interrupção das repetições do recalcado, ela serviu para embasarmos tanto os esforços desesperados do protagonista para evitar as rupturas definitivas com Ada e com a amante nos capítulos quinto e sexto do romance quanto o comportamento assintótico da disposição de Zeno para com Bigioni no texto Umbertino. No tocante à incapacidade de exercer as suas repetições compulsivas, o resultado que obtivemos foi que, nessa condição, Zeno opera segundo uma temporalidade específica, cuja principal característica é o tédio ao qual Zeno fica entregue e a qual denominamos temporalidade da nota única devido à alusão feita a tal monotonia sonora no início do quinto capítulo do romance. Identificamos que o protagonista está submetido à condição tediosa dessa temporalidade tanto em alguns momentos do romance, dos quais são especialmente importantes aqueles que decorrem da morte do pai e da perda definitiva de Ada devido à sua partida para Buenos Aires a fim de viver com a família do marido, quanto das "continuações", os quais decorrem da perda do controle dos negócios do pai para o filho de Olivi e do impasse sexual que se estabelece após o protagonista ser educado por Felicita à velhice.

Examinados os principais aspectos da compulsão à repetição do recalcado que conseguíamos investigar abarcando apenas o tempo da história dos textos do nosso corpus, consideramo-nos preparados para investigar a repetição do recalcado no romance abarcando também os tempos da narrativa e da narração e averiguando em que medida ela está articulada com outras temporalidades do romance. Começamos essa investigação excluindo o último capítulo devido às questões específicas que decorrem do seu contexto clínico. Essa é a tarefa à qual nos dedicamos no terceiro capítulo do presente trabalho. 
Após apresentarmos a avaliação generalizada da crítica de que há um afastamento sistemático da cronologia no romance em favor de um tempo subjetivo que é constituído pelos deslocamentos temporais realizados por Zeno, os primeiros resultados que obtivemos no terceiro capítulo deste trabalho são acréscimos que fizemos à avaliação mencionada de modo a introduzir o rompimento do romance com a temporalidade linear: a recusa da adoção generalizada da causalidade e do código hermenêutico. Em relação à causalidade, constatamos a sua debilidade no romance por meio de exemplos de: lacunas explicativas por parte do narrador no que tange a ligações que ele apresenta entre dois momentos da história ou entre os tempos da história e da narração; ausência de dependências causais que liguem os segmentos narrativos; e apelo direto do texto a figuras de oposição à ligação causal, inclusive em transições temáticas da narrativa. Quanto ao código hermenêutico, concluímos que há um enfraquecimento sistemático do código hermenêutico por meio de uma prolepse ou de uma informação dada pelo narrador que antecipa algum fato crucial da história em todos os capítulos da autobiografia.

Terminada a nossa abordagem introdutória do rompimento com a temporalidade linear, aprofundamos a nossa investigação sobre o modo pelo qual o romance elabora essa temporalidade obtendo três resultados principais. $\mathrm{O}$ primeiro deles consiste em que, apesar de concordarmos que há um rompimento com ela, a temporalidade linear ainda é parcialmente adotada na autobiografia de Zeno, o que estabelecemos verificando que a divisão da narrativa em capítulos é, em grande medida, feita cronologicamente e segundo os níveis do caminho da vida burguesa, um modelo linear e fortemente articulado da existência humana, o que empresta a essa divisão uma aparência de progressão lógico-causal e uma direcionalidade segundo a qual as expectativas possam ser guiadas durante a leitura.

Obtivemos o segundo resultado principal do aprofundamento da nossa investigação sobre a temporalidade linear articulando as conclusões contrárias de rompimento com ela e de adoção parcial a ela que propusemos inicialmente: a cronologia predomina como andamento geral da narrativa e, ao mesmo tempo, os desvios cronológicos aparecem com bastante frequência; as lacunas causais proliferam, mas geralmente são silenciadas ou encobertas por causas que se revelam insubsistentes, conforme exemplificamos com a proliferação de explicações sobre um mesmo assunto que não são devidamente articuladas, com o paradoxal recurso à superstição e ao destino para oferecer explicações, com a justificativa abandonada de modo displicente, 
com as conexões causais que se revelam insubsistentes em termos do próprio enredo ao serem analisadas criticamente e com o recurso à confusão entre a causalidade e a sucessão narrativa como procedimento bastante discreto e eficiente em despistar as carências de causalidade; e a narrativa gera expectativas que tendem a aderir ao modelo da vida burguesa no âmbito dos capítulos em geral e de cada um deles, ao passo que o desenvolvimento interno de cada capítulo, além de não ser elaborado segundo o código hermenêutico, é pontuado por desvios ao modelo burguês num grau suficiente para que tal adesão malogre nesse âmbito mais restrito.

Como o baixo nível das conexões causais com os eventos passados e das projeções por expectativa dos eventos futuros provoca a impressão geral de uma mera sucessão de fatos ou que eles se sucedam casualmente, demos o nome de temporalidade de onda (devido à caracterização da onda do mar como mera mudança incessante no início do quinto capítulo do romance) à temporalidade resultante da tendência da autobiografia de Zeno a romper com a linearidade temporal.

O último dos três resultados principais que obtivemos aprofundando a nossa investigação sobre a linearidade temporal apresenta duas experiências proporcionadas pelas disposições opostas em relação a essa temporalidade: os capítulos do romance que são dedicados à autobiografia prescrita pelo doutor S. elaboram um embate entre as temporalidades linear e de onda, o qual embasa tanto a experiência própria ao protagonista-narrador, na qual o embate é mantido indefinidamente sem atingir efetivamente um resultado, quanto a experiência alternativa, própria ao afastamento em relação ao ponto de vista do protagonista-narrador, de que um resultado é atingido, o do contínuo fracasso da temporalidade linear frente à de onda.

Exploradas as temporalidades que se oferecem com base na experiência imediata do protagonista-narrador, começamos a estudar como elas poderiam se articular com as temporalidades da repetição do recalcado e da nota única. Como preparação para essa tarefa, procuramos indícios que nos autorizassem a superar a experiência imediata do protagonista-narrador a ponto de até mesmo o embate temporal que a constitui se subordinar a outras temporalidades vigentes no texto. Encontramos tais indícios no início do romance - o prefácio, o preâmbulo e os primeiros parágrafos do terceiro capítulo -, do qual elaboramos uma leitura que se concentra no insistente questionamento da credibilidade do narrador por meio do alerta direto às mentiras do narrador, da alusão à dificuldade da interferência de outros tempos da vida de Zeno ao relatar um momento determinado e das complicações psicanalíticas para a 
confiabilidade do narrador, tais como a transferência, a leitura do tratado de psicanálise logo após a consulta com o doutor S. e a heterodoxia clínica da própria autobiografia, a qual ainda é agravada pela sua recusa a seguir a orientação médica de valorizar o tempo presente, principalmente no caso dos eventos mentais menos conscientes.

Uma vez que identificamos diversas dificuldades que justificam que nos desvinculemos da experiência imediata do narrador, oferecemos dois exemplos de como essas dificuldades podem ser superadas. O primeiro deles aborda um trecho do próprio início do romance: explicitamos como o episódio final do preâmbulo exemplifica de que modo as associações que se manifestam no presente da escrita podem fornecer material para investigar o passado mesmo que ela não seja voluntariamente pautada por essa relação temporal. O segundo exemplo trata do início do quinto capítulo do romance: exploramos os problemas narrativos que são suscitados pelas conexões temporais do relato apresentado por Zeno e expusemos como as repetições do recalcado que estão presentes no texto nos permitem resolvê-los. Assim, a análise desse exemplo nos serviu como justificativa da nossa proposta de usar a compulsão à repetição do recalcado como hipótese de abordagem para a autobiografia com o objetivo de superar as dificuldades geradas pela perspectiva de Zeno.

Retomando a compulsão à repetição do recalcado na nossa investigação, o nosso próximo resultado foi a determinação das amplas consequências de o narrador ser construído segundo essa compulsão para a elaboração dos tempos da narração, da narrativa e da história da autobiografia.

No caso do tempo da narração, destacamos as contribuições tanto para a construção do narrador fora da produção da narrativa, tais como a presença do tédio da temporalidade da nota única e as ações que são repetições do recalcado, quanto para a própria narrativa, nas quais as recorrências edipianas do protagonista e do narrador podem convergir ou divergir, e a divergência pode permanecer implícita. No caso das contribuições para a narrativa, destacamos o uso do discurso indireto livre para compartilhar enunciados entre as repetições do recalcado do protagonista e do narrador e as recorrências edipianas do narrador por meio das suas intervenções no relato, as quais podem introduzir implicitamente elementos alheios ao tempo da história.

No caso do tempo da narrativa, destacamos as contribuições das repetições edipianas do narrador para determinar diversos dos seus aspectos: a seleção das recordações, a condução das expectativas, a velocidade da narrativa, o grau de articulação em termos da ordem temporal e da causalidade, a seleção do próximo 
episódio numa silepse temática e o uso de inversões cronológicas.

No caso do tempo da história, as repetições edipianas do narrador são capazes de efetivamente alterá-lo ao construir a narrativa, o que identificamos numa inversão cronológica das atitudes do protagonista e em dois casos de sobreposição silenciosa de um tempo mítico, um dos quais consiste na inclusão de traços de Édipo como se fizessem parte de um sonho do protagonista.

A variedade e a abrangência das consequências que destacamos nos parágrafos anteriores tornam explícita a complexidade das relações entre as séries de repetições do recalcado do protagonista e do narrador. Sobre essas relações, destaquemos que a narrativa produzida por Zeno oferece simultaneamente as mudanças nas interferências entre as repetições do protagonista que se desenvolvem ao longo da sucessão dos segmentos narrativos e as interferências mútuas entre as repetições do narrador e o relato do comportamento repetitivo do protagonista dentro de um mesmo segmento narrativo, as quais também se desenvolvem no decorrer desses segmentos.

Destaquemos também que a intríseca tendência da compulsão à repetição a não reconhecer o recalcado nem as repetições que ele constitui, seja do protagonista, seja do narrador, faz com que a narrativa produzida por Zeno tenda a se distanciar em alguma medida da experiência vivida por ele no tempo da história para oferecer a experiência que ele tem de recordá-la e narrá-la, o que inclui a diegese em variados graus de distorção.

Exploradas as consequências da compulsão à repetição do recalcado do narrador para a elaboração temporal da autobiografia, terminamos a nossa investigação sobre a autobiografia estudando os seus principais aspectos no que se refere às articulações entre essa compulsão e as temporalidades linear e de onda. Por meio desse estudo, obtivemos três resultados principais.

O primeiro dos referidos resultados foram as articulações que geralmente se estabelecem entre as temporalidades linear, das repetições do recalcado e de onda. A principal articulação entre as duas primeiras consiste em que a primeira, por estar baseada numa direcionalidade do passado para o futuro, serve de instrumento de distorção para a repetição do recalcado, a qual justamente opera no sentido de dificultar o reconhecimento dos conteúdos submetidos ao recalque e, até mesmo, de que se trata de um processo recorrente; em especial, a temporalidade linear é inversa em relação à ordem temporal das recordações do que foi recalcado, que Freud considerava como sendo cronologicamente invertida. A temporalidade de onda participa dessa articulação 
justamente na medida em que a temporalidades linear é adotada para dificultar o reconhecimento do recalcado e das suas repetições, dado que o próprio sucesso desse objetivo impede a reconstituição das conexões causais entre os eventos e das expectativas efetivas.

Além da articulação da qual tratamos no parágrafo anterior, a temporalidade de onda se articula com a repetição do recalcado sem precisar da intermediação da temporalidade linear, seja pelos apelos de Zeno a alguma figura de oposição à causalidade, tais como a superstição e a originalidade radical, seja principalmente por meio das frequentes repetições do recalcado do narrador que perturbam o fluxo da história, da qual destacamos as recorrências edipianas que são explicitamente divergentes daquelas do protagonista, pois desestabilizam a própria história na medida em que as alternativas trazidas pelo tempo da narração são embasadas de modo tão frágil quanto as próprias ações do protagonista. Da referida desestabilização resulta que, assim como a própria narrativa não se encaminhou por si mesma para um maior esclarecimento da história, o narrador ainda aumenta a necessidade de esclarecimento com as suas repetições divergentes que desestabilizam a própria história que tenta relatar.

O segundo dos resultados em questão foram as críticas que são implicadas pelas articulações que investigamos: ao menos no caso de Zeno e de todos os que estão submetidos à compulsão da repetição do recalcado, a temporalidade linear e a concepção burguesa da vida são fatores de alienação do sujeito na medida em que operam no sentido de impedir que ele elabore um conhecimento efetivo sobre si mesmo por dificultarem o reconhecimento dessa repetição.

O último dos três resultados em questão é a variação existente entre o terceiro capítulo do romance e os demais que compõem a autobiografia no que se refere às articulações temporais que estudamos. Essa variação consiste em que o primeiro capítulo da autobiografia, devido tanto ao vínculo da escrita autobiográfica ao tratamento com o doutor S. por meio da abordagem temática que este recomendou quanto ao tema do vício tabagista ser uma repetição de baixo grau de variação, apresenta perturbações mais nítidas da temporalidade linear e promove a identificação das repetições a ponto de concorrer em alguns trechos com o estabelecimento de uma temporalidade de onda, de modo que esse capítulo serve de preparação para os demais da autobiografia, nos quais a subordinação da organização temática à cronológica e a diversidade de recorrências com variações relevantes dificultam bastante $\mathrm{o}$ 
reconhecimento das repetições, de modo a fazer com que prevaleça o embate direto entre as temporalidades linear e de onda.

Examinados os principais aspectos da repetição do recalcado e da sua articulação com outras temporalidades nos capítulos do romance que compõem a autobiografia prescrita pelo doutor S., dedicamos o quarto capítulo do presente trabalho ao estudo do último capítulo do romance, escrito como um diário composto por quatro seções, cada uma delas correspondendo ao trecho escrito por Zeno em determinada data.

Ao abordarmos a primeira seção do diário, o principal resultado que obtivemos foi de que, dentro do contexto clínico da terapia psicanalítica do protagonista com o doutor S., Zeno volta a se tornar narrador para, ao relatar a sua terapia, supostamente estabelecer que ela não melhorou a sua saúde e, portanto, num exercício de rivalidade edipiana contra o doutor S., rejeitar a investida final do psicanalista para que o protagonista retomasse o tratamento, segundo a qual ele voltaria à terapia porque eventualmente reconheceria o aprimoramento de saúde que a psicanálise lhe proporcionou.

Expusemos os dois modos pelos quais o narrador supostamente estabelece que a terapia não melhorou a sua saúde. O primeiro deles são as intromissões durante o relato pelas quais o narrador oferece oposição direta a ela quando relata momentos nos quais o protagonista não o fez: os sonhos, a acusação de omissão de uma informação e a investida final do doutor $\mathrm{S}$. O segundo modo consiste em impedir que o diário inicie com Zeno simplesmente narrando a única fase do tratamento na qual poderia haver pensado que ele pudesse funcionar; em vez disso, Zeno começa o diário com um trecho de intensa oposição do narrador à terapia, que inclui a argumentação de que a crença inicial nela era ilusória, e, portanto, só narra a fase de aceitação inicial da terapia pelo protagonista após apresentar toda uma argumentação contra o tratamento conduzido pelo doutor S. e contra as suas bases, que são os sonhos e a autobiografia.

Ao tratarmos da segunda e da terceira seções do diário, ampliamos o resultado que obtivemos de que a escrita do narrador é um instrumento para rejeitar a investida final do psicanalista. Na segunda seção, Zeno ratifica que a terapia não melhorou a sua saúde: ao acariciar uma camponesa, ele sugere que atingiu a excitação sexual agradecendo por ainda não estar curado e declarando que cessou o tratamento a tempo. $\mathrm{Na}$ terceira seção, o narrador afronta diretamente o valor de qualquer terapia alegando que a guerra torna desprezível a própria pretensão de ser curado. 
Obtivemos outros dois resultados de grande importância estudando a segunda seção do diário. O primeiro deles é a primeira transformação da repetição do recalcado de Zeno no romance, a qual consiste numa cura parcial das recorrências edipianas na medida em que terminam as repetições que dependem apenas do desejo pela mãe. Para identificarmos esse término, o nosso ponto de partida foi o fim do fetichismo de Zeno, que é indiretamente abordado tanto na sua reação do protagonista-narrador à quantidade variada de dias de cada mês e à mudança incessante da natureza quanto no modo pelo qual o protagonista permanece sexualmente indiferente a Teresina ou é atraído por ela. O segundo resultado consiste em que o fim das repetições edipianas de fetichismo, unidade e totalidade também causa tanto o abandono implícito da temporalidade linear e, portanto, o amplo domínio da temporalidade de onda quanto a própria mudança da escrita autobiográfica para diarística que decorre de tal abandono. Precisamos ressalvar apenas que a primeira seção do diário ainda apresenta um embate entre as temporalidades linear e de onda, seja porque o próprio processo de cura ainda está em transição durante a escrita dessa seção, seja por retomar a história de Zeno antes da sua transformação pela cura parcial.

Ao abordarmos a quarta seção do diário, o principal resultado que obtivemos foi a segunda transformação da repetição do recalcado de Zeno no romance, a qual consiste numa segunda cura parcial das recorrências edipianas na medida em que também terminam as repetições da rivalidade edipiana, conforme abordamos em quatro casos: o término das iniciativas para assumir os negócios herdados do pai por meio da vitória no comércio radicalmente transformado pela guerra; a hostilidade que deixa de ser velada para se tornar declarada a ponto da quarta seção assumir a forma de uma carta hostil que Zeno envia ao doutor S., além de o narrador expor claramente a presença da competição e da agressividade na espécie humana como um todo nos últimos parágrafos do romance; o fim da repetição oscilatória dos cuidados com a saúde por meio da nova concepção que o narrador expõe sobre a saúde e a doença como inseparáveis; e o fim das competições nas quais Zeno está potencial ou efetivamente em desvantagem na medida que se propõe efetivamente a vencer as competições, tal como no caso da edificação de um terapeuta como o doutor S. por meio das reflexões sobre as noções de saúde e doença.

Observemos que a segunda cura é parcial, pois, tal como na primeira cura, Zeno não nos dá nenhum indício de que se tornou consciente das relações edipianas com os pais e das suas repetições. 
Esclarecemos também que não ocorre um fim absoluto das repetições do recalcado de Zeno, conforme exemplificamos tanto com a sensação de sufocamento e a preferência dada à competição pelo espaço na abordagem dada pelo narrador à degradação ambiental e à superpopulação quanto com a hostilidade velada que é inerente à concepção de uma explosão capaz de destruir a vida do planeta sem que ninguém a ouça; na verdade, as repetições do recalcado se tornam desprovidas de importância prática, tais como nos exemplos mencionados.

Como resultado complementar, constatamos que Zeno não está mais submetido à temporalidade da nota única apesar do fim de todas as suas repetições do recalcado, o que é sugerido por ele estar ocupado o dia inteiro com o comércio quando escreve a carta para o doutor $\mathrm{S}$.

Examinados os principais aspectos da repetição do recalcado e da sua articulação com outras temporalidades no último capítulo do romance, investigamos o âmbito global do romance a fim de determinar qual é temporalidade resultante após as duas curas parciais de Zeno, uma vez que elas fizeram com que as temporalidades cruciais para a experiência temporal do protagonista-narrador na autobiografia e nas três primeiras seções do diário deixem de ser relevantes após a segunda cura parcial. Nessa investigação, constatamos que a escrita de Zeno muda segundo uma gradação nas posições temporais da narração em relação à história: essa posição é ulterior na autobiografia, torna-se intercalada e simultânea no diário e termina como anterior nos parágrafos finais da carta ao doutor S. Também constatamos que a escrita de Zeno é dedicada à narração autobiográfica ao longo de quase todo o romance, o que não é o caso da carta, pois ela se ocupa principalmente da reflexão sobre a saúde e sobre as ameaças para a existência da humanidade. Por fim, constatamos que o romance transcorre no ambiente burguês de Trieste até a segunda seção do diário, a partir da qual se amplia progressivamente para abranger o campo, as nações em guerra e a própria humanidade, da qual trata sob a perspectiva das ameaças para a sua existência.

Obtivemos dois resultados principais da nossa investigação sobre o âmbito global do romance. O primeiro deles é o estabelecimento de que a experiência temporal que se instala após as duas curas parciais de Zeno é a da superação da sujeição da sua ação e da sua escrita, na forma de narração, ao passado de âmbito individual na medida em que Zeno se torna um agente orientado para o presente de âmbito coletivo por meio da sua ocupação comercial e um escritor que se dedica a reflexões sobre o presente e o futuro que está em preparação que abrangem a humanidade e a vida em geral do 
planeta. O segundo resultado é o reconhecimento da reflexão sobre as ameaças da degradação ambiental, da superpopulação e dos artefatos de destruição em massa como uma crítica à incapacidade da sociedade burguesa de analisar a si própria na medida em que quem se dedica a identificar as tendências dessa sociedade para a própria destruição é alguém que permanece irredutível a ela até o fim do romance.

Finalizada a nossa investigação sobre o romance, dedicamos o quinto capítulo do presente trabalho a completar o estudo das "continuações", o qual iniciamos no segundo capítulo, tratando da repetição do recalcado também nos tempos da narrativa e da narração e averiguando em que medida ela contribui para a elaboração das articulações temporais das "continuações".

Uma vez que Zeno deixou de exercer repetições do recalcado que tenham importância prática no fim do romance, retomamos o estudo das "continuações" pela recaída na compulsão à repetição. Como principal resultado desse estudo, baseado no texto Un contratto, identificamos a recaída do protagonista nas repetições da rivalidade edipiana à medida que, após o fim da guerra, perde o controle da empresa herdada do pai para o filho de Olivi, de modo que, em termos da compulsão repetitiva, ele volta à situação na qual se encontrava antes da segunda cura parcial, o que inclui a temporalidade da nota única, a qual volta a afetá-lo. Também expusemos as limitações dessa recaída: Zeno não considera que a sua antiga doença retornou nem retoma a repetição oscilatória da abstinência e do retorno ao tabagismo, da qual sobram apenas solilóquios sem nenhuma relevância prática. Além disso, raticamos que a recaída não inclui repetições que dependem apenas do desejo pela mãe esclarecendo que o fetichismo demonstrado por Zeno no episódio de Bigioni no texto Umbertino é desprovido de importância prática.

Complementando o resultado anterior, identificamos os poucos trechos das "continuações" que tratam da história entre a segunda cura parcial de Zeno e a sua recaída nas repetições da rivalidade edipiana e verificamos que as repetições do recalcado que encontramos nesses trechos são exclusivas do narrador ou não possuem relevância prática.

Estabelecida a recaída de Zeno nas repetições da rivalidade edipiana, investigamos os principais aspectos da articulação entre os tempos da história e da narrativa em cada uma das "continuações". Por meio desse estudo, obtivemos três resultados principais. O primeiro deles é específico do texto Un contratto e consiste na progressividade narrativa que domina a perda gradual que Zeno sofre do controle dos 
negócios herdados para o filho de Olivi.

O segundo dos resultados em questão consiste na rejeição da temporalidade linear em favor da temporalidade de onda e no abandono sistemático da sucessão temporal, uma característica inexistente no romance. Esse resultado possui uma aplicação apenas parcial no caso do texto Un contratto: a progressividade narrativa da abordagem dada à perda gradual do controle dos negócios herdados por Zeno para o filho de Olivi é diluída por sequências de ações que não contribuem para o desenvolvimento dessa perda de controle a partir do contrato proposto pelo administrador até estancar na mera acumulação de eventos posteriores ao dia da assinatura do contrato, os quais não são expostos segundo uma ordenação temporal. A situação é bem diferente nos demais textos das "continuações", o que podemos constatar sem maiores dificuldades na medida em que eles são formados por narrativas ou partes de uma única narrativa que, em grande medida, não estão ordenadas cronologicamente nem são submetidas a um esforço de articulação, o que geralmente faz com que o entendimento do enredo de cada uma delas não exija a leitura das demais.

O último dos três resultados em questão consiste na convergência das narrativas que compõem cada um dos textos das "continuações" para um final no qual o protagonista está submetido à inibição de alguma das suas repetições do recalcado. Nos textos Un contratto, Le confessioni del vegliardo e Umbertino, as repetições inibidas abarcam a relação do protagonista com vários dos principais personagens com os quais convive: o filho de Olivi, Alfio, Antonia, Umbertino, Bigioni, Carlo e Renata. No texto Il mio ozio, o relato termina com a inibição da principal repetição oscilatória dos cuidados com a saúde na forma do impasse sexual provocado pela educação recebida de Felicita. Apenas o texto Prefazione não adota exatamente esse modelo, pois o impasse sexual já está presente na situação inicial do protagonista no relato de abertura desse texto.

Examinadas a recaída de Zeno nas recorrências da rivalidade edipiana e as posteriores inibições das repetições do recalcado do protagonista, estudamos como Zeno volta a se constituir como escritor autobiográfico e concluímos que a escrita justamente serve para que ele retome as repetições inibidas.

Para obtermos a conclusão mencionada, analisamos o modo pelo qual a velhice do narrador, concebida como uma doença, está vinculada à temporalidade da nota única, a qual é causada pela inibição das repetições do recalcado, o modo pelo qual as experiências de rejuvenescimento que Zeno relata o retiram temporariamente dessa 
inibição e como ele descobre a escrita como uma forma sistemática de retomar as repetições inibidas relendo os manuscritos que escreveu na época da terapia com o doutor S.

Estabelecido como Zeno volta a se constituir como escritor autobiográfico, investigamos quais são as maneiras pelas quais os tempos da narrativa e da narração são construídos de modo a satifazer a condição de que o narrador retome as repetições inibidas. Como resultado da nossa investigação, obtivemos duas maneiras de satisfazer essa condição.

A primeira maneira de satisfazer a condição em questão é o mero relato de episódios nos quais o protagonista ainda exercia as repetições que depois se tornariam inibidas e, portanto, é de grande importância para a seleção de quais momentos da história entram na composição da narrativa. À repetição edipiana promovida pelo próprio relato, o narrador pode acrescentar outras ocorrências da mesma repetição que sejam específicas do tempo da narração.

A segunda maneira de satisfazer a condição em questão é o exercício por parte do narrador de recorrências edipianas que o protagonista não exercia no momento que está sendo relatado ou exerceu apenas de forma parcial ou insuficiente, de modo que somente a repetição do narrador é satisfatória. Isso pode ocorrer pelo mero relato, como nos casos de narração de hostilidades contra algum rival antes da recaída na compulsão edipiana ou de a própria narração operar como uma rivalidade edipiana apesar de o episódio relatado ser desprovido de ações hostis.

Extrapolando o mero relato, o narrador exerce repetições alheias ao protagonista de muitos modos, conforme pode ser verificado com base nos seguintes exemplos: as antecipações referentes à morte de Valentino; a referência à morte de Copler, que não é personagem de nenhum relato das "continuações"; os comentários hostis a Antonia, mesmo em episódios anteriores ao envolvimento com Valentino; a comparação entre personagens, incluindo alguns que não aparecem em nenhum relato das "continuações", que resulte na depreciação de um deles, geralmente associados por meio da hereditariedade; e as descrições físicas, por meio das quais expressa tanto as imperfeições de Alfio quanto a admiração pelo corpo de Renata.

Examinado como o narrador efetivamente retoma as repetições inibidas, investigamos o limite da referida retomada, o qual consiste em que ela está restrita ao âmbito da escrita, e as suas consequências principais para os tempos da narração e da narrativa. Por meio dessa investigação, obtivemos três resultados principais. O primeiro 
deles é o reconhecimento de que a escrita de Zeno nas "continuações" elabora um embate entre a escrita autobiográfica, na qual ele é capaz de retomar as repetições inibidas, e a vida na velhice, na qual elas permanecem submetidas à inibição.

O segundos dos resultados em questão é a relevância do embate entre a escrita e a vida para o tempo da narração na medida em que esse embate é frequentemente incorporado, de diversas maneiras, na composição dos trechos nos quais Zeno fica restrito a esse tempo, pois, nesses trechos, ele é incapaz de ignorar que as repetições permanecem inibidas fora do âmbito da escrita. Esse resultado é especialmente importante para o texto Prefazione, no qual esse embate é incorporado em todos os temas abordados por Zeno a partir do trecho no qual ele faz as últimas referências ao episódio inicial, o da falsa Dondi; além disso, ao terminar reafirmando a inibição das repetições fora do âmbito da escrita, esse texto reproduz com o narrador e com o prefácio inteiro o que os demais textos das "continuações" apresentam como situação final da repetição do recalcado do protagonista em cada uma das suas narrativas.

Por fim, o terceiro dos resultados em questão determina em que medida o tempo da narrativa é elaborado com base no embate entre a vida e a escrita. Usando a declaração de Zeno sobre a ausência de futuro como diferença entre as duas vezes nas quais se dedicou à escrita autobiográfica, constatamos que, ao contrário das "continuações", o narrador do romance exercia repetições do recalcado fora do âmbito da escrita por meio do próprio ato de narrar: a autobiografia participava do exercício da repetição dos cuidados com a saúde por servir de preparação para a terapia psicanalítica, e o diário é uma repetição da rivalidade edipiana contra o doutor S. por ser dedicado à rejeição da investida final do psicanalista para que Zeno retorne à terapia.

Ao não ser capaz de retomar nenhuma repetição inibida fora do âmbito da escrita, o narrador das "continuações" é dominado pela ausência de futuro em detrimento da sucessão indefinidamente prolongada que é própria a qualquer compulsão, de modo que o embate entre a escrita e a vida opera no âmbito da escrita reagindo ao exercício das recorrências edipianas dentro da narrativa por meio da rejeição da sucessão requerida pela compulsão, seja pela desvalorização da sucessão temporal (apenas parcialmente no caso do texto Un contratto, conforme já assinalamos), seja pela recorrente afirmação do fim da narrativa pela justaposição de várias narrativas, as quais convergem para o próprio fim do exercício das repetições do recalcado.

Uma vez que apresentamos os principais resultados que obtivemos por meio da nossa investigação da compulsão à repetição do recalcado como base da elaboração 
temporal dos textos narrados por Zeno, concluímos que a abordagem que adotamos para esses textos foi capaz de expor o alcance singular da experimentação artística de Svevo sobre o tempo literário, tanto por explicitarmos a complexidade temporal que é elaborada pelo escritor quanto por explorarmos as transformações produzidas nas relações temporais ao longo dos textos.

No caso das transformações nas relações temporais, destaquemos outra vez a contribuição proporcionada pela abordagem que adotamos, dado que essas transformações dependem da compulsão à repetição do recalcado: a autobiografia abandona a silepse temática adotada no seu capítulo inicial em favor da ordem cronológica para dificultar o reconhecimento das repetições do recalcado; a autobiografia é trocada pelo diário devido à primeira cura parcial de Zeno; o diário é substituído pela carta hostil ao doutor S. por causa do fim das recorrências edipianas que possuam relevância prática; e os textos das “continuações" se baseiam em relações temporais inéditas em relação ao romance devido à retomada das repetições do recalcado que foram inibidas ficar restrita ao âmbito da escrita.

Com base nas nossas considerações, ratificamos a proposta que fizemos no final do primeiro capítulo do presente trabalho, a saber, que a escrita de Svevo, algumas vezes pouco valorizada em termos de inovação, opera, nos textos do nosso corpus, como um valioso experimento artístico sobre a temporalidade literária no qual explora as mais variadas relações temporais a partir da compulsão à repetição do recalcado. Parece-nos que tal experimentação é uma contribuição estética de tal ordem que coloca esses textos de Svevo à altura dos principais livros inovadores dentro da prosa escrita pelas vanguardas europeias nas primeiras décadas do século XX.

Para encerrarmos esta conclusão, apresentaremos duas propostas para futuras investigações. A primeira delas é a de abordar outros aspectos dos textos narrados por Zeno que também poderiam ser estudados sob a perspectiva da compulsão à repetição do recalcado. Por exemplo, a ironia poderia ser abordada desse modo na medida em que opera revelando sutilmente para outrem a inadequação entre enunciado e enunciação, o que poderíamos considerar uma formação de compromisso, pela qual conteúdos recalcados podem ser repetidos sem que precisem ser reconhecidos como tais.

Baseamos a segunda proposta para futuras investigações na seguinte consideração: grande parte da complexidade temporal dos textos narrados por Zeno resulta do desconhecimento do próprio narrador sobre os acontecimentos que está relatando, o que atribuimos ao recalcamento segundo o qual o narrador é construído. 
Essa consideração serve-nos como sugestão de que poderíamos obter resultados de complexidade semelhante investigando outros textos literários nos quais tal desconhecimento do narrador também é relevante, qualquer que seja a causa dessa carência cognitiva. 


\section{REFERÊNCIAS BIBLIOGRÁFICAS}

\section{1 - Obras de Italo Svevo}

SVEVO, Italo. Carteggio. Milão: dall'Oglio, 1965.

—. Racconti, saggi, pagine sparse. Milão: dall'Oglio, 1968.

—. Romanzi e “continuazioni”. Milão: Mondadori, 2004.

A consciência de Zeno. Tradução de Ivo Barroso. Rio de Janeiro: Nova Fronteira, 2006.

\section{2 - Obras de Sigmund Freud}

FREUD, Sigmund. O caso Schreber, artigos sobre técnica e outros trabalhos (1911-1913). Edição "standard” bras. das obras psicológicas completas. Rio de Janeiro: Imago, 1969, v. 12.

A história do movimento psicanalítico, artigos sobre a metapsicologia e outros trabalhos (1914-1916). Edição "standard" bras. das obras psicológicas completas. Rio de Janeiro: Imago, 1974, v. 14.

—. Conferências introdutórias sobre psicanálise (1915-1916). Edição "standard" bras. das obras psicológicas completas. Rio de Janeiro: Imago, 1976a, v. 15-16.

História de uma neurose infantil e outros trabalhos (1917-1919). Edição "standard" bras. das obras psicológicas completas. Rio de Janeiro: Imago, 1976b, v. 17.

Os chistes e sua relação com o inconsciente (1905). Edição "standard" bras. das obras psicológicas completas. Rio de Janeiro: Imago, 1977, v. 8. 
A interpretação dos sonhos (1900). Edição "standard" bras. das obras psicológicas completas. 2. ed. Rio de Janeiro: Imago, 1987a, v. 4-5.

—. Sobre a psicopatologia da vida cotidiana (1901). Edição "standard" bras. das obras psicológicas completas. 2. ed. Rio de Janeiro: Imago, 1987b, v. 6.

. Um caso de histeria, três ensaios sobre a sexualidade e outros trabalhos (1901-1905). Edição "standard” bras. das obras psicológicas completas. 2. ed. Rio de Janeiro: Imago, 1989, v. 7.

. Cinco lições de psicanálise (1910). Edição "standard" bras. das obras psicológicas completas. 2. ed. Rio de Janeiro: Imago, 2006, v. 11.

\section{3 - Obras sobre Svevo}

BARILLI, Renato. La linea Svevo-Pirandello. Milão: Mondadori, 2003.

BARTOLONI, Paolo. Il tempo e la memoria in Le confessioni del vegliardo e Prefazione. Avanguardia, v. VI, n. 18, pp. 101-122, 2001.

BIASIN, Gian-Paolo. Un Deo gratias qualunque: Svevo, il linguaggio, il sapere. Itálica, v. 61, n. 2, pp. 134-146, verão de 1984.

BUCCHERI, M.; COSTA, E. (cura). Italo Svevo tra moderno e postmoderno. Ravena: Longo, 1995.

CAMERINO, Giuseppe Antonio. Italo Svevo: significato e caratteri di una poetica mitteleuropea. In: CACCIAGLIA, N.; GUZZETA, L. (cura). Italo Svevo scrittore europeo: atti del convegno internazionale (Perugia, 18-21 marzo 1991). Florença: Leo S. Olschki, 1994. 
CASTELAN, Ivair Carlos. Zeno Cosini, uma identidade possível? 2008. Dissertação (Mestrado) - Faculdade de Filosofia, Letras e Ciências Humanas Universidade de São Paulo, São Paulo, 2008.

—. Trieste, inaptidão e ciúme: três componentes fundantes do romance sveviano. 2014. Tese (Doutorado) - Faculdade de Filosofia, Letras e Ciências Humanas - Universidade de São Paulo, São Paulo, 2014.

CASTRIS, Arcangelo Leone de. Il decadentismo italiano: Svevo, Pirandello, D’Annunzio. Bari: Laterza, 1989.

CLAAR, Micaela Pretolani. Guida alla lettura di Svevo. Milão: Mondadori, 1986.

DAVID, Michel. La psicoanalisi nella cultura italiana. 3. ed. Turim: Bollati Boringhieri, 1990.

DE CIA, Patricia. Um romance no meio do caminho: La coscienza di Zeno e os paradoxos do fim de século. 2008. Dissertação (Mestrado) - Faculdade de Filosofia, Letras e Ciências Humanas - Universidade de São Paulo, São Paulo, 2008.

DEBENEDETTI, Giacomo. Il romanzo del Novecento. Milão: Garzanti, 1998.

DEDOLA, Rossana. Il fumo, la maschera, gli insetti: crisi del romanzo e nuove proposte narrative in Svevo, Pirandelllo e Tozzi. Itálica, v. 69, n. 1, pp. 19-29, primavera de 1992.

FRANTZ, Adroaldo José. A psicanálise em La coscienza di Zeno: contribuições literárias e abordagem questionadora da terapêutica. 2014. Dissertação (Mestrado) - Faculdade de Filosofia, Letras e Ciências Humanas Universidade de São Paulo, São Paulo, 2014.

GHIDETTI, Enrico. Italo Svevo. La coscienza di um borghese triestino. Roma: Edizioni di Storia e Letteratura, 2006. 
GIANNANTONIO, Pompeo. La Trieste mitteleuropea di Svevo. In: CACCIAGLIA, N.; GUZZETA, L. (cura). Italo Svevo scrittore europeo: atti del convegno internazionale (Perugia, 18-21 marzo 1991). Florença: Leo S. Olschki, 1994.

GUGLIELMI, G. La prosa italiana del Novecento. Umorismo, metafisica, grottesco. Turim: Einaudi, 1986, v. 1.

GUGLIELMINETTI, Marziano. La contestazione del reale. Nápoles: Liguori, 1974.

_. Il romanzo del Novecento italiano. Roma: Riuniti, 1986.

GUIDOTTI, Angela. Zeno e i suoi doppi: le commedie di Svevo. 2. ed. Pisa: ETS, 1990.

LAURETIS, Teresa de. La sintassi del desiderio: struttura e forme del romanzo sveviano. Ravena: Longo, 1976.

LAVAGETTO, Mario. L'impiegato Schmitz e altri saggi su Svevo. Turim: Einaudi, 1975.

—. Svevo e la crisi del romanzo europeu. In: ROSA, Alberto Asor (cura). Letteratura italiana del Novecento. Bilancio di un secolo. Turim: Einaudi, 2000.

- Il romanzo oltre la fine del mondo. In: SVEVO, Italo. Romanzi $e$ “continuazioni”. Milão: Mondadori, 2004.

LUNETTA, Mario. Invito alla lettura di Italo Svevo. Milão: Mursia, 2002.

LUTI, G. L'ora di Mefistofole. Studi sveviani vecchi e nuovi. Florença: La Nuova Italia, 1990.

MAIER, Bruno. Italo Svevo. 3 ed. Milão: Mursia, 1971.

MAXIA, Sandro. Svevo e la prosa del Novecento. Roma: Laterza, 1977. 
MIORIN, Cristiane Vanessa. Narcisismo literário: espelhamento, procura e fuga em A consciência de Zeno e "O meu ócio", de Italo Svevo. 2006. Dissertação (Mestrado) - Instituto de Biociências, Letras e Ciências Exatas, Universidade Estadual Paulista, São José do Rio Preto, 2006.

—. O percurso evolutivo do narcisismo literário em Uma vida, A consciência de Zeno e capítulos esparsos, de Italo Svevo. 2013. Tese (Doutorado) Instituto de Biociências, Letras e Ciências Exatas, Universidade Estadual Paulista, São José do Rio Preto, 2013.

MOLONEY, Brian. Italo Svevo narratore. Lezioni triestine. Gorizia: Libreria Editrice Goriziana, 1998.

MUSSARA-SCHRODER, Ulla. Italo Svevo e la modernità europea. In: CACCIAGLIA, N.; GUZZETA, L. (cura). Italo Svevo scrittore europeo: atti del convegno internazionale (Perugia, 18-21 marzo 1991). Florença: Leo S. Olschki, 1994.

PALUMBO, Matteo. Svevo e i suoi autori. MLN, v. 101, n. 1, pp. 1-30, jan. 1996.

PETRONIO, Giuseppe (cura). Il caso Svevo. Palermo: Palumbo, 1988.

RAMOS, Maria Celeste Tommasello. A representação em Memórias Póstumas de Brás Cubas e A Consciência de Zeno. 2001. Tese (Doutorado) - Instituto de Biociências, Letras e Ciências Exatas, Universidade Estadual Paulista, São José do Rio Preto, 2001.

ROBBE-GRILLET, Alain. La conscience malade de Zéno. In: Pour un nouveau roman. Paris: Minuit, 1961.

ROQUE, Araguaia Solange de Souza. Minha consciência daria um romance: o personagem sujeito do(ao) inconsciente na interface literatura $e$ psicanálise. São José do Rio Preto: Ed. UNESP, 2010. 
SACCONE, Eduardo. Svevo, Zeno e la psicanalisi. $M L N$, v. 85, n. 1, ed. italiana, pp. 67-82, jan. 1970.

- Malattia e psicanalisi nella Coscienza di Zeno. MLN, v. 88, n. 1, ed. italiana, pp. 1-43, jan. 1973.

Ancora su Svevo e la psicanalisi. $M L N$, v. 90, n. 1, ed. italiana, pp. 127136, jan. 1975.

SANCHES, Maria Teresa Nunes. Memórias Póstumas de Brás Cubas e a Consciência de Zeno: representações históricas das sociedades brasileira e italiana. 2003. Dissertação (Mestrado) - Instituto de Biociências, Letras e Ciências Exatas, Universidade Estadual Paulista, São José do Rio Preto, 2003.

. Uma vida, Senilidade e a Consciência de Zeno: um estudo da paródia sveviana aos heróis da tradição literária italiana. 2016. Tese (Doutorado) - Instituto de Biociências, Letras e Ciências Exatas, Universidade Estadual Paulista, São José do Rio Preto, 2016.

SAVELLI, Giulio. L’ambiguità necessaria. Zeno e il suo lettore. Milão: Franco Angeli, 1998.

SOUZA, Fábio Rosa. Ironia como forma em La coscienza di Zeno de Italo Svevo. 2015. Dissertação (Mestrado) - Faculdade de Filosofia, Letras e Ciências Humanas - Universidade de São Paulo, São Paulo, 2015.

SPAGNOLETTI, Giacinto. Svevo: da Una vita a La coscienza di Zeno. Modena: Mucchi, 1991.

STASI, Beatrice. Svevo. Bolonha: Il Mulino, 2009.

TEDESCO, Natale. La coscienza letteraria del Novecento: Gozzano, Svevo ed altri esemplari. Palermo: Flaccovio, 1999. 
TORTORA, Massimiliano. Il punto su Svevo: 1994-2004. Moderna, v. VI, pp. 169188, 2. ${ }^{\circ}$ sem. 2004.

VICENTINI, Marzia Terenzi. Encontro com Svevo. 1984. Tese (Doutorado) Faculdade de Filosofia, Letras e Ciências Humanas - Universidade de São Paulo, São Paulo, 1984.

VITTORINI, Fabio. Svevo: guida alla Conscienza di Zeno. Roma: Carocci, 2003.

VOGHERA, G. Gli anni della psicanalisi. Pordenone: Studio Tesi, 1980.

WILDEN, Anthony. Death, desire and repetition in Svevo's Zeno. MLN, v. 84, n. 1, ed. italiana, pp. 98-119, jan. 1969.

4 - Obras de referência sobre o tempo visando os textos literários e obras gerais

BAKHTIN, Mikhail. Questões de literatura e de estética (a teoria do romance). 3. ed. São Paulo: Hucitec, 1993.

BARTHES, Roland et al. Análise estrutural da narrativa: pesquisas semiológicas.

2. ed. Petrópolis: Vozes, 1972.

—. S/Z. Lisboa: Edições 70, 1980.

BOSI, Alfredo. O tempo e os tempos. In: NOVAES, Adauto (org.). Tempo e História. São Paulo: Companhia das Letras, Secretaria Municipal de Cultura, 1992.

—. O ser e o tempo da poesia. 6. ed. São Paulo: Companhia das Letras, 2000.

BUTOR, Michel. Repertório. São Paulo: Perspectiva, 1974.

CHATMAN, Seymour. Story and discourse. Narrative structure in fiction and Film. Nova Iorque: Cornell University, 1978.

ECO, Umberto. Seis passeios pelos bosques da ficção. São Paulo: Companhia das Letras, 1994. 
GENETTE, Gérard. Discurso da narrativa. Lisboa: Vega, 1987.

KERN, S. Il tempo e lo spazio. La percezione del mondo tra Otto e Novecento. Bolonha: Il Mulino, 2007.

LE POULICHET, S. O tempo na psicanálise. Rio de Janeiro: Jorge Zahar, 1996. (Col. Transmissão da Psicanálise, v. 49).

LEOPOLDO E SILVA, F. Bergson, Proust: tensões do tempo. In: NOVAES, Adauto (org.). Tempo e História. São Paulo: Companhia das Letras, Secretaria Municipal de Cultura, 1992.

MALDONATO, Mauro. Passagens de tempo. São Paulo: SESC SP, 2012.

A subversão do ser: identidade, mundo, tempo e espaço: fenomenologia de uma mutação. São Paulo: SESC SP, 2014.

MENDILOW, Adam Abraham. O tempo e o romance. Porto Alegre: Globo, 1972.

MEYERHOFF, H. O tempo na literatura. São Paulo: McGraw-Hill do Brasil, 1976.

NUNES, Benedito. O tempo na narrativa. 2. ed. São Paulo: Ática, 1995.

POUILLON, Jean. O tempo no romance. São Paulo: Cultrix, 1974.

PRALORAN, M. Il tempo nel romanzo. In: MORETTI, F. (cura). Il romanzo. Turim: Einaudi, 2002, v. 2.

RICOEUR, Paul. Tempo e narrativa. Campinas: Papirus, 1994, v. 1-3.

ROSSUM-GUYON, Françoise van. Critique du roman: essai sur "La modification" de Michel Butor. Paris: Gallimard, 1970.

SCHOLES, Robert.; KELLOGG, Robert. Natureza da narrativa. São Paulo: McGraw-Hill do Brasil, 1977.

SEGRE, Cesare. Avviamento all'analisi del texto letterario. Turim: Einaudi, 1985. As estruturas e o tempo. São Paulo: Perpectiva, 1986.

SÓFOCLES. A trilogia tebana. 8. ed. Rio de Janeiro: Jorge Zahar, 1998. 
WEINRICH, Harald. Estrutura y función de los tiempos en el lenguaje. Madri: Gredos, 1974. 